\author{
UNIVERSIDADE DE SÃO PAULO \\ FACULDADE DE FILOSOFIA, LETRAS E CIÊNCIAS HUMANAS \\ DEPARTAMENTO DE GEOGRAFIA \\ PROGRAMA DE PÓS-GRADUAÇÃO EM GEOGRAFIA HUMANA
}

\title{
TERRITÓRIO USADO E CIRCUITO SUPERIOR MARGINAL: EQUIPAMENTOS MÉDICO-HOSPITALARES EM CAMPINAS, RIBEIRÃO PRETO E SÃO JOSÉ DO RIO PRETO (SP)
}

Virna Carvalho David

\begin{abstract}
Dissertação apresentada ao Programa de PósGraduação em Geografia Humana do Departamento de Geografia da Faculdade de Filosofia, Letras e Ciências Humanas da Universidade de São Paulo, para obtenção do título de Mestre em Geografia Humana.
\end{abstract}

Orientadora: Professora Doutora María Laura Silveira 


\section{ERRATA}

ONDE SE LÊ OS MAPAS 2, 3 E 4 DA PÁGINA 87, LEIA-SE OS MAPAS ABAIXO

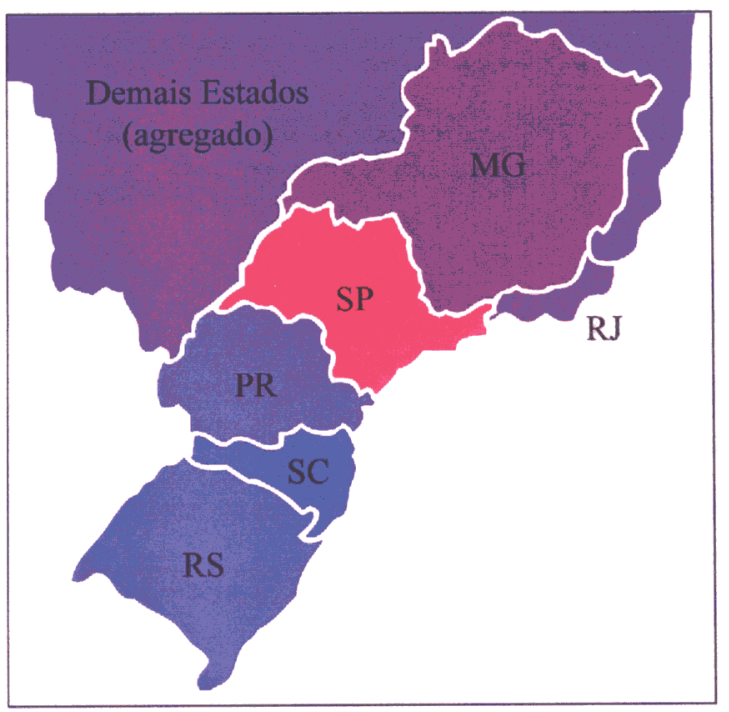

1996

Unidades locais industriais por Unidade da Federação

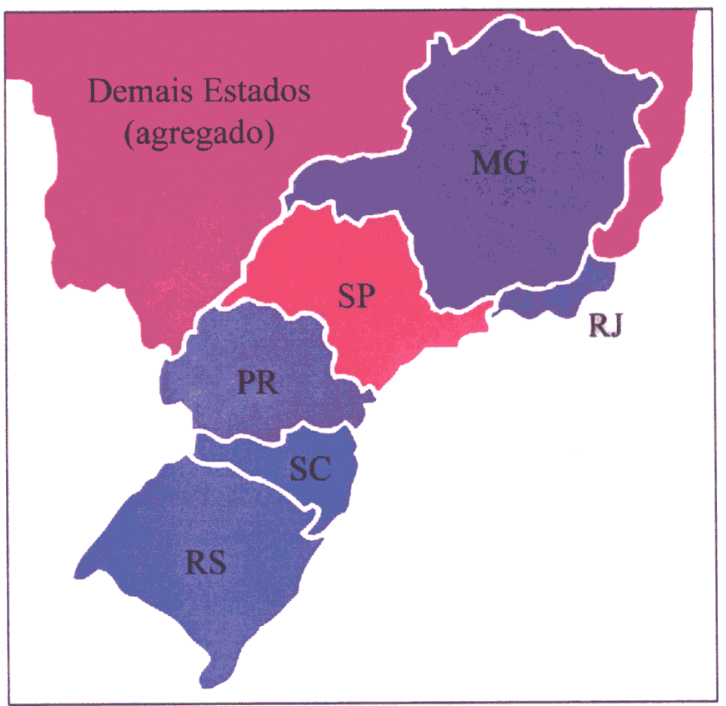

\section{0}

Unidades locais industriais por Unidade da Federação
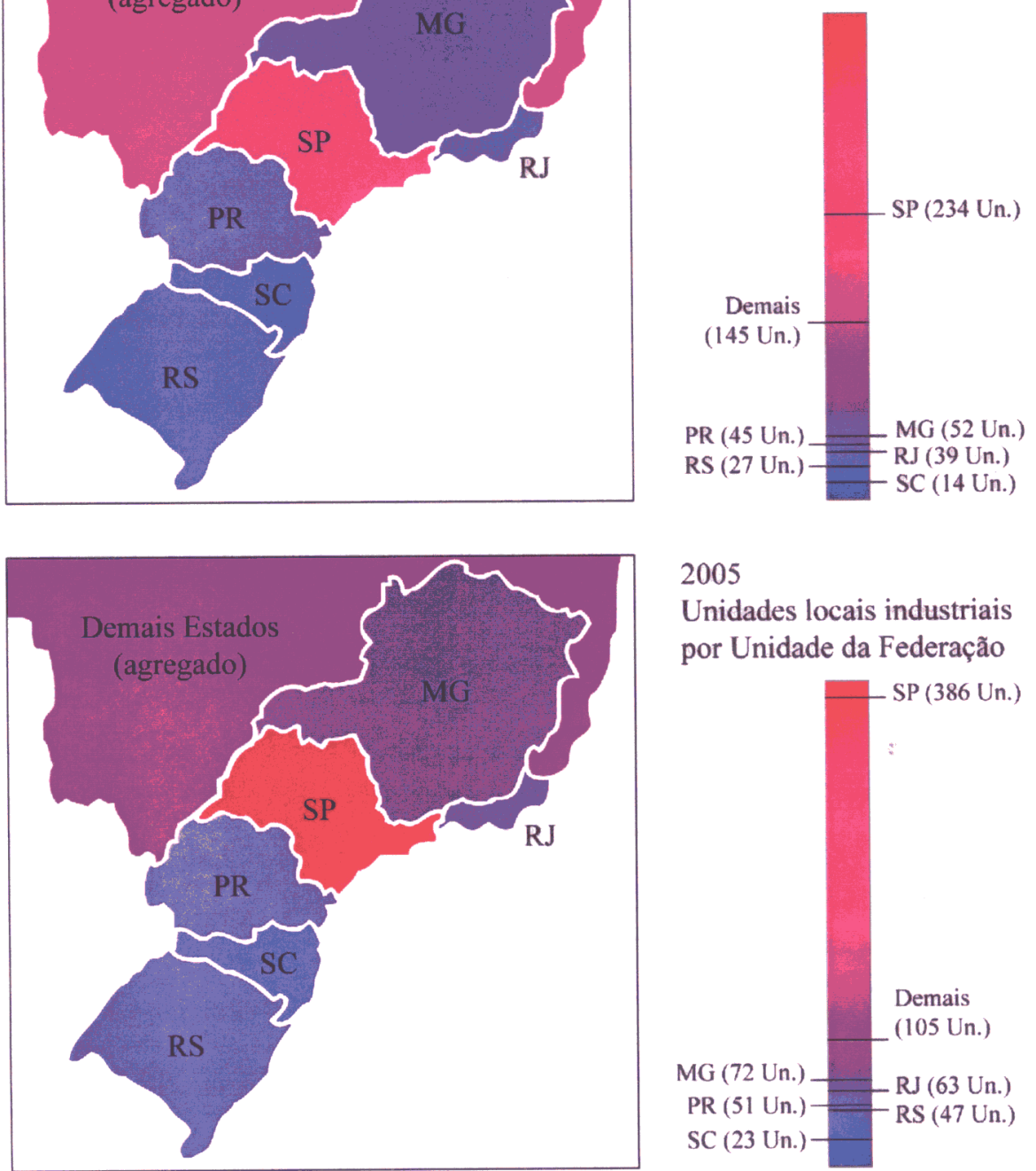

2005

Unidades locais industriais por Unidade da Federação

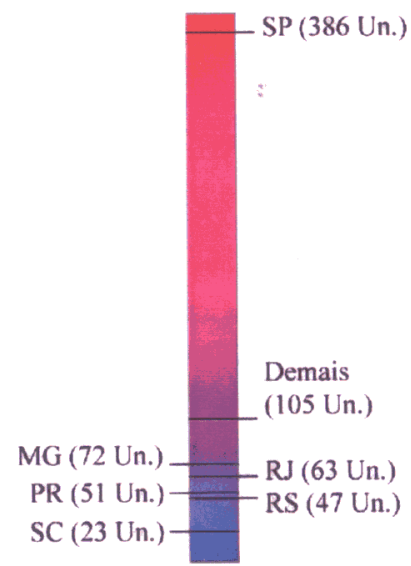


Dedico este trabalho aos meus mestres e pais 
Ainda que o trabalho acadêmico se realize por um tom solitário, seu fruto deixa evidente a dimensão do cotidiano partilhado e as interdependências que o tornam possível. Aqui, gostaria de agradecer algumas pessoas que fizeram essa tarefa um aprendizado não apenas ao pensamento, mas para a vida.

Primeiramente, agradeço à professora María Laura Silveira, quem me inspirou e orientou nessa trajetória. Por cada dedicada e paciente orientação, por sua preciosa amizade, serei sempre grata pela confiança e generosidade. Agradeço ao professor Plínio Tsai, amigo que há longo tempo me ensina a aprender e aprumar a vontade no caminho. Agradeço seu incansável entusiasmo em acompanhar seus alunos. Agradeço ainda ao professor que não conheci, Milton Santos, com quem aprendo a ter amor e coragem pela verdade.

Agradeço aos amigos Villy Creuz, Flavia Grimm e Marina Montenegro pela amizade sincera de todos os dias e o zelo incondicional na realização desse trabalho. Agradeço também aos amigos Fabio Tosi, Pablo Ibañez, Fabíola Iozzi, Mariana Vercesi, Luis Ribeiro, Lise Mielnik pela forte amizade e estímulo presente. Às amigas de sempre Silvia Futada, Cristiane Bambini, Alice e Laura Biato, Luciana Palharini, Carolina Laranjeira, Fabiana Assad. Ao Raphael Curioso e José Vicente, pela amizade. Ao amigo raro Diego, por tudo.

Agradeço à professora Ana Clara Torres Ribeiro, quem jamais deixou de me ensinar sobre a importância do diálogo e o cuidado com o outro. À professora María Adélia Aparecida de Souza, quem me apresentou à Geografia. À professora Mónica Arroyo, agradeço seu esforço alegre em ensinar e entrega para transformar obstáculos em oportunidades. Ao professor e amigo Fabio Contel, pela ajuda ao trabalho sério. Aos amigos do Laboplan, pelos estudos e debates da vida universitária. Aos queridos Daniel Huertas, Julia Andrade, Jonatas Mendonça, Edison Bicudo, Eliza Almeida e Ana Pereira, pelas palavras de apoio.

Ainda é preciso agradecer o auxílio da Fundação de Amparo à Pesquisa do Estado de São Paulo.

Ao Rodrigo Gonçalves, pela amizade sem preço e pela disposição na feitura dos mapas. À Beatriz Rodder, pela amizade alegre e caminho de afeto. Aos amigos Christian Hilton, Loyane Ferreira, Tattiane Marques, Cibele Furlan, Chogni-la, Nirvana França, Choekyi e todos queridos com quem convivo, agradeço muito.

Aos irmãos Saulo Carvalho e Hité e aos meus pais Saulo David e Aivone Carvalho, amigos que não fazem possível dimensionar a gratidão. 


\section{RESUMO}

No contexto da especificidade da urbanização brasileira, onde as cidades crescem simultaneamente às formas de trabalho com capitais reduzidos e tecnologias menos modernas, nossa pesquisa analisa o território usado por diferentes agentes do sistema produtivo de equipamentos médico-hospitalares no Estado de São Paulo, atentando para as diferentes divisões do trabalho existentes na forma dos circuitos da economia urbana.

Valorizado de forma seletiva, o meio construído permite que atividades mais e menos rentáveis se instalem, enquanto a coexistência de divisões do trabalho que datam de diferentes épocas assegura uma dinâmica interdependente entre os circuitos da economia urbana.

Neste sentido, discutimos a existência de um circuito superior marginal ligado às atividades de produção de equipamentos médico-hospitalares em Campinas, Ribeirão Preto e São José do Rio Preto (SP) e o papel complementar que este cumpre para os serviços de saúde do país. 


\section{ABSTRACT}

In the context of the specificity of Brazilian urbanization, where simultaneous with the growth of the cities, the types of work with reduced capital and less modern technologies also grow, our research analyses the territory used by different agents of the medical-hospital equipment's production system in the state of São Paulo, looking at the different divisions of labor, existing in ways of the circuits of urban economy.

Valued in a selective way, the environment building allows installation of more or less profitable activities, while the coexistence of divisions of labor of different ages ensures an interdependent dynamic among the circuits of the urban economy.

In this way, we discuss the existence of a marginal upper circuit related to the medical-hospital equipment's production in Campinas, Ribeirão Preto e São José do Rio Preto (SP) and its complementary function that it accomplishes for the brazilian health services. 


\section{RESUMEN}

En el contexto de la especificidad de la urbanización brasileña, donde las ciudades están creciendo, mientras que los tipos de trabajo con el capital reducido y menos modernas tecnologías, nuestra investigación examina el territorio utilizado por los diferentes actores del sistema productivo de los equipos médicos en el Estado de São Paulo, teniendo en cuenta las diferentes divisiones del trabajo existen en la forma de los circuitos de la economía urbana.

Valorado de forma selectiva, el entorno construido permite que más y menos rentables las actividades se han instalado, mientras que la coexistencia de las divisiones de trabajo que datan de diferentes períodos proporciona una dinámica de interdependencia entre los circuitos de la economía urbana.

En este sentido, se discute la existencia de un marginal superior a la producción de equipos médicos en Campinas, Ribeirão Preto y São José do Rio Preto (SP) y el papel complementario que se ajuste a los servicios de salud en el país. 


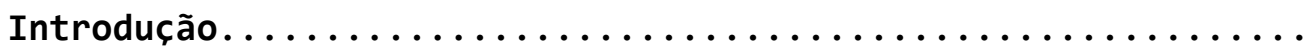

1.1. A natureza técnica e científica dos cuidados médicos.....

1.1.1. O nascimento da instituição médica e algumas considerações sobre a ciência clínica..................

1.1.2. O universalismo dos direitos sociais e o sistema de

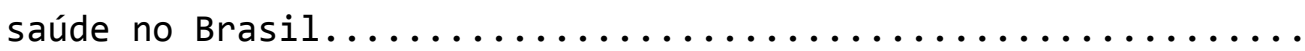

1.2. O meio geográfico e a tecnificação dos cuidados à saúde.. 36

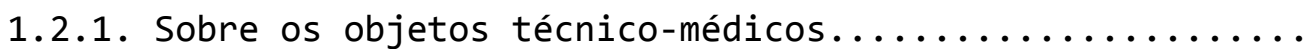

1.2.1.i. A realidade sistêmica dos equipamentos médicohospitalares e a medicina como instituição industrial .......

1.2.2. Cientifização dos equipamentos médico-hospitalares e

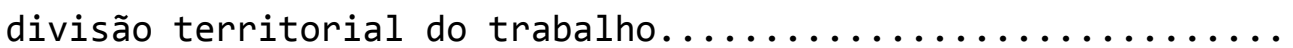

1.2.2.i. Sobre a distribuição desigual dos serviços de saúde..

1.2.2.ii. Necessidades médicas e estratégias de mercado.......

1.2.3. O endurecimento tecnológico dos equipamentos médico-

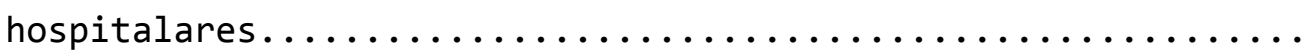

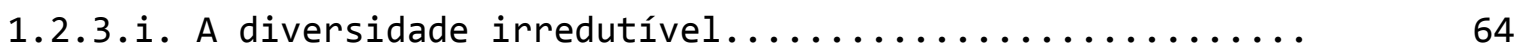

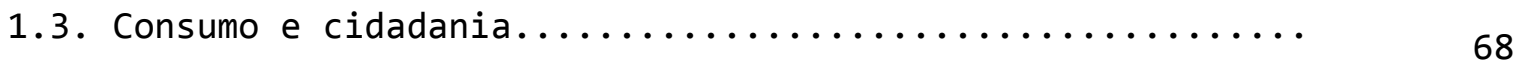

1.3.1. 0 discurso competente da ciência ................ 70

1.3.2. A saúde como consumo e vínculo cidadão.............. 73

Capítulo 2. 0 território ativo na constituição das existências

2.1. A espessura da divisão do trabalho na região concentrada.

2.1.1. A formação socioespacial ligada à produção nacional de

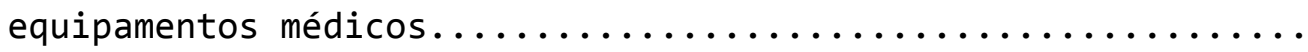

2.1.2. Processo de urbanização e modernização seletiva........

2.1.2.i. O circuito superior puro e as grandes empresas de

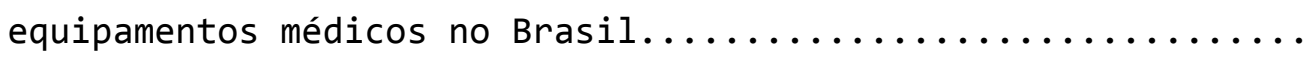


2.1.3. A produção nacional de equipamentos médico-hospitalares

2.1.3.i. Sobre a diversidade de divisões territoriais do

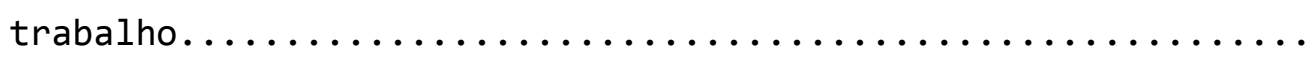

2.1.3.ii. A contiguidade das cidades para diferentes

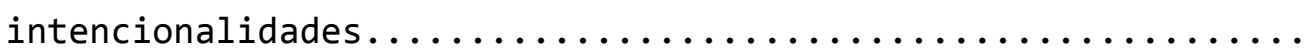

2.2. O papel dos hospitais na economia urbana.............

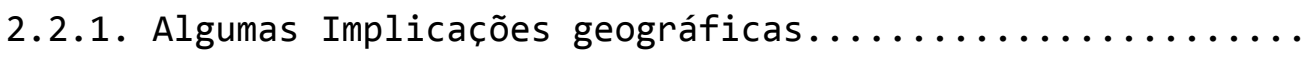

Capítulo 3. A norma como variável motor da divisão do trabalho

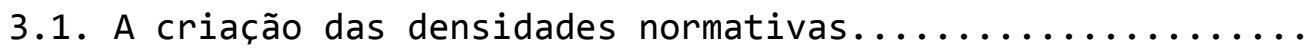

3.1.1. Alguns efeitos nas cidades de Campinas Ribeirão Preto e

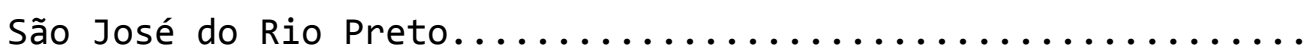

3.2. O papel das normas nas obsolescências das formas de trabalho.

3.3. Controvérsias das políticas públicas..............

Capítulo 4. 0 acontecer solidário na dinâmica do circuito superior marginal

4.1 A força criativa na interdependência do trabalho nas cidades de Campinas, Ribeirão Preto e São José do Rio

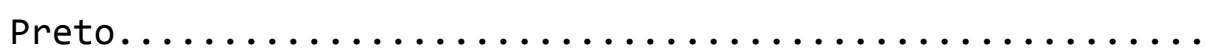

4.2 0 cotidiano compartilhado nas cidades de Campinas,

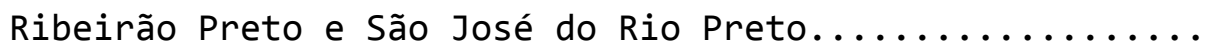


Índice de Mapas, Gráficos e Tabelas

MAPA 1 Centralidade urbana em relação à oferta de serviços de saúde - Brasil, 2005 ............

MAPA 2

Número de unidades industriais de equipamentos médico-hospitalares no Brasil (destaque para a Região Concentrada, exceto o Espírito Santo) -

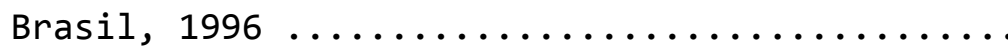

MAPA 3 Número de unidades industriais de equipamentos médico-hospitalares no Brasil (destaque para a Região Concentrada, exceto o Espírito Santo) Brasil, 2000 ..........................

MAPA 4 Número de unidades industriais de equipamentos médico-hospitalares no Brasil (destaque para a Região Concentrada, exceto o Espírito Santo) -

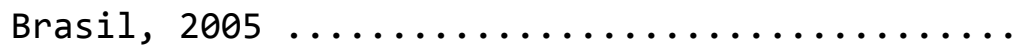

MAPA 5 Municípios fabricantes de equipamentos médicohospitalares no Estado de São Paulo - 2005 .....

GRAFICO 1 Número total e por esfera administrativa dos estabelecimentos de saúde sem internaçãoBrasil, 1976 - 2005 ....................

GRAFICO 2 Distribuição dos equipamentos de Raio-X por 100 mil habitantes, segundo as Grandes Regiões Brasil, 1999 - 2005 .....................

GRAFICO 3 Distribuição dos tomógrafos por $100 \mathrm{mil}$ habitantes, segundo as Grandes Regiões - Brasil,

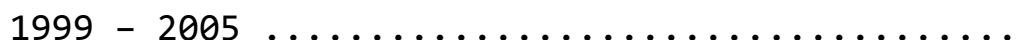

GRAFICO 4 Distribuição de equipamentos por $100 \mathrm{mil}$ habitantes, segundo as Grandes Regiões - Brasil,

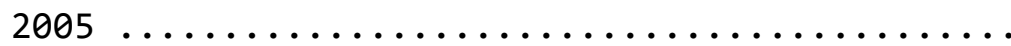

GRAFICO 5 Porcentagem da mortalidade por tipo de causa de morte - Brasil, 1990 - 2006................

GRAFICO 6 Número de estabelecimentos de saúde por tipo de prestador - Brasil, 2005 - 2010 ............. 
TABELA 1

Distribuição de doenças infecciosas e parasitárias, por Região - Brasil, 1990 - 2006 (porcentagem no total das causas de morte por

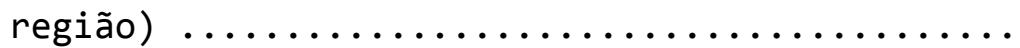

TABELA 2 Principais importadores e exportadores no comércio internacional de aparelhos e instrumentos para usos médico-hospitalares -

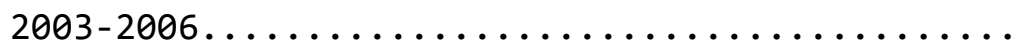

TABELA 3 Despesa de rendimento familiar e de recebimento familiar utilizados com saúde, por Regiões

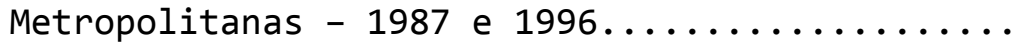

TABELA $4 \quad$ Unidades produtivas de equipamentos médicohospitalares nos Estados das Regiões Sul e Sudeste (exceto Espírito Santo) - Brasil, 1996..

TABELA 5 Unidades produtivas de equipamentos médicohospitalares nos Estados das Regiões Sul e Sudeste (exceto Espírito Santo)- Brasil, 2000...

TABELA 6 Unidades produtivas de equipamentos médicohospitalares nos Estados das Regiões Sul e Sudeste (exceto Espírito Santo)- Brasil, 2005...

TABELA 7 Unidades produtivas de equipamentos médicohospitalares, com 5 ou mais pessoas ocupadas Brasil, Sul e Sudeste (exceto Espírito Santo) -

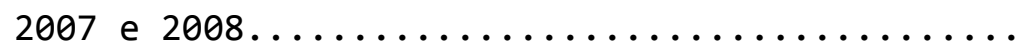

TABELA 8 Tendência à metropolização no Brasil, 1950 -

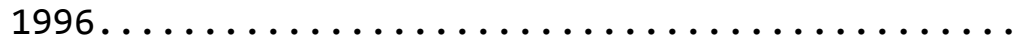

TABELA 9 População e Valor Adicionado Industrial de Campinas, Ribeirão Preto e São José do

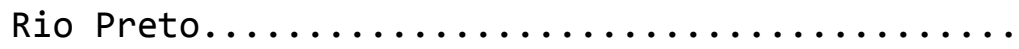

TABELA 10 Empresas fabricantes de equipamentos médicoshospitalares (CNAE 1.0/33.1) no Estado de São Paulo, por cidade $-2005 \ldots \ldots \ldots \ldots \ldots \ldots \ldots$

TABELA 11 Estabelecimentos de saúde por tipo de prestador - Campinas, Ribeirão Preto e São José do Rio

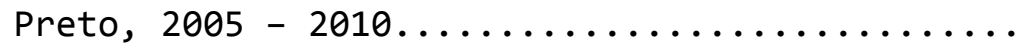

TABELA 12 Tipo de compradores de equipamentos médicohospitalares no país, 2007 - 2009............ 
No contexto da especificidade da urbanização brasileira, onde as cidades crescem simultaneamente às formas de trabalho com capitais reduzidos e tecnologias menos modernas, a presente dissertação buscou analisar o território usado por diferentes agentes do sistema produtivo de equipamentos médicohospitalares, atentando para a diversidade de divisões territoriais do trabalho, existentes na forma dos circuitos da economia urbana (Santos, 1979).

No Brasil, $80 \%$ das indústrias de equipamentos médicos são pequenas e médias e possuem enorme importância no fornecimento desses objetos ao sistema de saúde do país. Mais da metade destas se encontram no Estado de São Paulo, onde observou-se empresas ocupando interstícios próprios do que caracteriza a porção marginal do circuito superior da economia urbana, como nas cidades de Campinas, Ribeirão Preto e São José do Rio Preto.

Contudo, a partir da urbanização e seus processos recentes relacionados à difusão do meio técnico-científico informacional (Santos, 1994), o território usado para consumir e produzir saúde mostrou a força de algumas grandes empresas hegemônicas para acelerar as modernizações dos equipamentos médicos.

Veremos como esse circuito superior puro se vale da constituição material e organizacional do território para sua realização mais eficaz. Nesse sentido, a cidade é concebida como meio construído e como um grande mercado (Silveira, 2004), pois, à medida que um novo subsistema técnico se instala, a economia urbana se torna mais complexa e segmentada.

As maiores cidades mostram como a acelerada corrida científica e tecnológica, representada por um processo de tecnificação da medicina, beneficia um tipo de consumo e imprime uma dinâmica territorial seletiva de renovação técnica e normativa, na qual vemos multiplicar as formas de trabalho, tanto contraditórias como solidárias.

Tal processo é, entretanto, revelador da vulnerabilidade da produção nacional de bens e serviços ligados aos equipamentos médicos, pois muitos são os agentes que, diante da susbtituição de uma divisão do trabalho por outra mais moderna, buscam sobreviver nos diferentes contextos da economia urbana. 
É a noção de técnica que está no cerne das questões que buscamos discutir. Max Sorre (1948) já nos ensinara que a técnica não se limita a suas aplicações mecânicas, ela é, pois, o meio de sobrevivência, afirma Gaudin (1978). Nessa perspectiva, a técnica é entendida por uma dialética reveladora de que o modo como a sociedade produz seus objetos é indissociável do modo como os objetos transformam essa sociedade.

Milton Santos (1996) quando define o objeto de estudo da geografia parece nos apontar para a importância da noção de espaço na constituição do fenômeno social total, onde técnica e história se realizam mutuamente.

Para avançarmos no estudo dos equipamentos médicos, procuramos distinguir o que seria um objeto técnico-médico em si e o modo como se mostra enquanto um sistema de objetos e de ações, em que tanto o objeto como a sociedade se realizam.

Daí partirmos da definição proposta por Santos (1996), de que o espaço geográfico é "um conjunto indissociável, solidário e também contraditório, de sistemas de objetos e sistemas de ações, não considerados isoladamente, mas como o quadro único no qual a história se dá”.

A técnica de nossa época mostra ser fruto da ciência, e é a partir dessas variáveis que o novo momento do modo de produção vêm propor a constituição de uma ordem espacial contemporânea ao lado da informação e da finança.

Os equipamentos médico-hospitalares respondem a um crescente incremento técnico científico e informacional para a modernização da medicina e sua difusão, associada à ampliação dos consumos da saúde.

Vemos que os objetos hoje são técnico-informacionais e participam do novo modo de organização dos processos produtivos, assim como constituem as formas mais banais de fazer e reproduzir a vida. Daí o meio geográfico do período contemporâneo ser definido como meio técnico-científico informacional (Santos, 1994).

A modernização por que passam os equipamentos médicohospitalares, bem como os estabelecimentos de saúde, revela que estes são a base material de ações científicas e tecnicamente 
fundadas e propõem uma certa organização e transformação do espaço geográfico que repercutem sobre as formas de trabalho possíveis.

Nesse sentido, enquanto uma nova geografia está sempre a se produzir pelas formas com que os diferentes lugares participam do movimento do todo, são os lugares que revelam o modo como a história geografiza as possibilidades de cada período.

Compreendida por um processo socioespacial, a tecnificação da saúde é uma possibilidade do mundo que nos convida a refletir sobre o modo como esse acontecer mais largo se realiza num pedaço do território. Nesse sentido, esse evento, como o tempo possível que se torna efetivo nos lugares, mostra seu papel na diferenciação do território nacional.

Da mesma maneira, o modo como produção e o consumo da saúde repercutem sobre a formação socioespacial (Santos, 1977) revela que, em cada momento, os lugares compreendem tempos distintos, maneiras particulares de realizar as possibilidades do presente. Vemos que tal constituição se torna indissociável dos processos recentes da urbanização do país.

Essa perspectiva histórica nos leva ao território como uma forma impura, isto é, requer constante revisão em função de que o valor dos lugares está sempre mudando. Daí que é "o uso do território, e não o território em si mesmo que faz dele objeto de análise social”, ensina Santos (1994:15).

Como proposta por Silveira (1999), a situação geográfica, quando vinculada ao modo como as possibilidades existentes no mundo se realizam nos lugares, poderia contribuir de um modo diferente daquele das noções legadas da geografia regional.

o alargamento das ações graças às tecnologias da informação nos convida a observação que o valor dos lugares não está dado apenas pela resultante de sua relação com outros lugares, mas, sobretudo, pelo modo como os lugares permitem a realização diferenciada das possibilidades do presente.

Dessa maneira, a divisão do trabalho se destaca como categoria não apenas econômica ou social, mas também geográfica, quando associamos à ela o movimento de distribuição dos recursos. A distribuição das possibilidades de acesso à saúde moderna ou de trabalho para produzir saúde expõe as desigualdades no país. 
Num tempo em que as técnicas revelam sua natureza invasora, onde é cada vez mais difícil separar a influência da divisão internacional do trabalho daquela da divisão do trabalho interno a cada país, o papel da formação socioespacial nessa mediação torna-se decisivo na especificidade dos lugares, assim como o papel do Estado na constituição das oportunidades à nação.

Desse modo, os conteúdos dos lugares constituídos a partir das variáveis do período atual, isto é, a tecnociência, a informação e a finança, revelam a manifestação diferenciada do fenômeno técnico, dada pela combinação particular dos elementos do mundo em cada situação geográfica.

Nessa direção, observamos que a distribuição dos elementos que constituem o período atual não se faz sobre um território ahistórico. o meio construído (Harvey, 1982) em cada cidade mostra de que forma exerce um papel ativo sobre a localização dos eventos atuais.

Cada uma das três cidades, Campinas, Ribeirão Preto e São José do Rio Preto é, portanto, portadora de uma coerência espacial própria que nos convida a refletir a respeito do modo como cada "pedaço" do território é usado pelas variáveis que constituem o presente.

Pela formação produtiva historicamente constituída nessas cidades do interior de São Paulo, essas cidades possuem uma densidade e complexidade de divisões do trabalho. Mas também por estarem no eixo das políticas atuais de modernização e, ainda, por serem referência em saúde em suas regiões, essas cidades são reveladoras desses processos no contexto da fomação socioespacial brasileira e manifestam as tendências das modernizações atuais.

Atualmente, as técnicas da informação tornam os conteúdos dos lugares solidários na escala do planeta. Mostram, daí, as variáveis que constituem os fenômenos atuais, ampliando as escalas de ação dos diferentes agentes. Diante da possibilidade de dividir as etapas da produção entre os diferentes lugares, 0 imperativo da circulação permite ver como tais cidades expressam a interdependência do trabalho e, desse modo, como as novas dinâmicas da saúde participam do processo de diferenciação geográfica. 
Diante dessa natureza interdependente dos fenômenos contemporâneos, o acontecer solidário dos lugares (Santos, 1996:132), como “a realização compulsória de tarefas comuns, mesmo que o projeto não seja comum” torna evidente uma multiplicidade de divisões territoriais do trabalho nas formas de realização da existência.

De um lado a economia moderna impõe aos lugares uma divisão hegemônica do trabalho que busca subordinar as formas de trabalho precedentes, de outro a cidade emerge como um conjunto de divisões territoriais do trabalho, em que racionalidades distintas permitem a coexistência de diferentes agentes e contextos.

Da mesma forma, essa simultaneidade de ações de diferentes temporalidades imprime o desafio de análise para captar o território usado em sua diversidade. Daí a divisão do trabalho, compreendida como um conceito plural, permitir, a partir dos circuitos da economia urbana (Santos, 1979), a observação sobre os interstícios praticados por agentes de força desigual.

Decorrentes da expansão mundial das modernizações capitalistas, Milton Santos (1972, 1975, 1978, 1979) - contemporâneo a outros autores, como T. Mc Gee, 1968; A. Mabogunje, 1965; A. Quijano, 1970; D. Slater, 1982 - realiza um esforço de estudo sobre a especificidade do espaço dos países do terceiro mundo.

Propõe, nesse sentido, a teoria dos circuitos da economia urbana no entendimento do processo histórico de constituição segmentada da economia urbana desses países, daí os dois circuitos da economia urbana, um circuito superior e outro circuito inferior, ambos resultado do mesmo fenômeno de modernização tecnológica.

Cidades que são lugares privilegiados na hierarquia urbana, dada a densiddade e complexidade das divisões territoriais do trabalho, Campinas, Ribeirão Preto e São José do Rio Preto mostram as modernizações, seletivas e aceleradas, do período da globalização.

Apreendermos a tecnificação da saúde de modo integrado aos processos da urbanização brasileira, com atenção às diferentes demandas a serem satisfeitas, tanto para produzir como para consumir saúde, procuramos distinguir analítica e historicamente os circuitos da economia urbana. 
Nas economias urbanas de Campinas, de Ribeirão Preto e de São José do Rio Preto, temos o que Santos (1979) define como circuito superior, o resultado direto das modernizações, constituído por bancos, comércio, indústria e serviços modernos. Trata-se de uma dinâmica hegemônica de uso do território.

Já o circuito inferior é resultado indireto do mesmo fenômeno de modernização, pois esta, quando chega com a força para fazer envelhecer o sistema técnico anterior, segmenta a economia urbana que se adapta, criando atividades de produção e consumo voltadas às dinâmicas das populações mais pobres.

Ainda, como explica Santos (1979), a modernização seletiva autoriza a convivência de formas mistas, pertencentes tanto às atividades herdadas de divisões territoriais do trabalho pretéritas como às formas de trabalho emergentes, incluídas nas atividades modernas. Como a modernização não se instala em todas as fases do trabalho, os elementos são aceitos em diferentes graus, criando uma porção marginal do circuito superior.

o conceito de uso do território por diferentes agentes, apesar da desigualdade de suas forças, da mesma forma, o conceito de situação geográfica, a partir do qual buscamos entender os lugares enquanto o modo de ser do fenômeno técnico, e o conceito de divisão do trabalho como uma noção plural que permite observar a interdependência do trabalho, foram fundamentos para observar os circuitos da economia urbana nas três cidades.

$\cos$

Para compreender a saúde no Brasil, seja como um sistema produtivo ou como direito ao acesso público aos serviços, partimos do entendimento da urbanização brasileira e de seus processos recentes.

De todo modo, os estudos a respeito do sistema de saúde brasileiro, assim como a história particular do sistema produtivo dos equipamentos médicos, nos diferentes momentos do país, foram iniciais e necessários para podermos percorrer nosso objetivo analítico, que é compreender a existência de um circuito superior marginal ligado aos equipamentos médicos.

Vimos que a modernização dos serviços de saúde e as demandas pela produção de bens e serviços ligados aos equipamentos médicos encontram-se na esteira dos processos atuais da 
urbanização brasileira. Daí nossa opção metodológica de não cindir o estudo a um tipo específico de equipamento médico. Apontaremos alguns elementos significativos para a análise.

Ainda que seja possível observar os efeitos das modernizações na saúde de forma abrangente a partir de um único ou dois equipamentos médicos, essa decisão teria duas implicações contrárias à concepção fundamental de que o território usado envolve todos os atores, numa trama de cooperação e conflito, sendo, por isso, sinônimo de espaço banal (Santos, 1996b), espaço de todos.

A primeira consiste em apontar um único objeto técnico-médico em específico, como qualquer um daqueles mais modernos, tais como ressonâncias, tomógrafos, entre outros - os mesmos que tornam relativamente opacos os serviços de saúde noutros lugares do país. Isso significaria um olhar para a economia urbana definida em grande medida pela importação dos aparelhos.

A segunda consiste em que optar pelo estudo de apenas alguns produtos ou alguns agentes, enquanto temos uma indústria nacional estabelecida e altamente diversificada, seria um disparate em relação aos nossos objetivos. Isso porque observar apenas alguns agentes levaria a perceber uma economia urbana menos rica do que ela de fato se revela.

A maneira de tratar empiricamente a diversidade a partir do entendimento de que a divisão do trabalho é um conceito plural. Daí os circuitos da economia urbana serem observados pela interdependência do trabalho e permitirem a captação dessa diversidade no interior de um processo mais abrangente.

Nesse sentido, a partir da dinâmica territorial dos equipamentos mais e mais sofisticados, veríamos como, diante das modernizações tecnológicas, sobrevivem os diferentes agentes da economia urbana ligados aos equipamentos médicos nas cidades. São eles, fabricantes, vendedores, representantes, prestadores de serviços de reparo, dentre outros.

Em diferentes contextos a diversidade de agentes compreende também um arsenal de produtos demandados pela prática médica. Essa variedade de formas de trabalho, em que muitas atividades estão ligadas à sobrevivência, conduziu-nos a busca por compreender os processos que tornam existente um circuito superior marginal. 
Isso quer dizer que as maneiras de persistir num mercado de acelerada renovação técnica e normativa, controlado por atores hegemônicos, revelam processos onde as formas parecem surgir como ponto de partida para, eventualmente, observar mecanismos escondidos de dominação e subordinação entre os agentes de força desigual.

$\cos$

A metodologia compreendeu momentos de pesquisa bibliográfica e de pesquisa empírica. Com alguns aportes teóricos da Geografia, procuramos conhecer o sistema produtivo de equipamentos médicoshospitalares a partir de periódicos científicos e publicações governamentais voltados ao tema. Dedicamo-nos à compreensão dos debates vinculados à produção desses objetos, também no âmbito do sistema de saúde no país.

Por meio do Sistema de Informação do Ministério da Saúde, observamos a intensificação do uso dos equipamentos para suprir uma crescente demanda de diagnósticos e tratamentos médicos, assim como a distribuição desigual dos objetos técnicos. Para conhecer a produção nacional desses equipamentos, usamos as bases de dados do Instituto Brasileiro de Geografia e Estatística (IBGE) e a Relação Anual de Informações Sociais (RAIS).

Caminho de método amadurecido ao longo do primeiro período da pesquisa, nossa análise partiu da dinâmica recente da urbanização, onde a distribuição dos serviços de saúde apareceu como um dado do território nacional. Nesse sentido, adentrar a análise do fenômeno técnico pela economia urbana, e não pelos serviços de saúde, preservou-nos do tratamento da problemática de estudo da saúde de forma setorizada.

Procuramos então conhecer algumas abordagens da economia espacial nos países subdesenvolvidos, assim como algumas referências em Geografia Urbana, Economia Regional, e ainda filósofos e geógrafos da técnica, buscando enfrentar o desafio de método de criar meios analíticos diante das situações geográficas do estudo, assim como aperfeiçoar nossa formação em Geografia.

Primeiro momento da operacionalização da pesquisa foi a definição das cidades a serem estudadas. Campinas, Ribeirão Preto e São José do Rio Preto (SP) foram opções metodológicas e 
históricas por apresentarem uma complexidade de divisões do trabalho capaz de abrigar os circuitos da economia urbana, aqui vistos a partir da existência de indústrias de equipamentos médicos e de serviços públicos de referência em saúde.

Quando nos dirigimos à análise dos mecanismos modernos de incorporação de tecnologias médicas ao serviço de saúde, fomos convidados a refletir a respeito do papel do Estado. A verificação sobre as atuais políticas de desenvolvimento industrial relacionadas à saúde foi uma importante via para assegurar coerência e pertinência na compreensão das dinâmicas da economia urbana.

Quando nos lançamos a uma aproximação dos agentes da economia urbana, com o objetivo de conhecer as empresas situadas nos municípios, foi necessária a elaboração prévia de uma variedade de questões e pontos adequados à enorme diversidade de atividades envolvidas no sistema produtivo destes bens e serviços.

Com questionários adaptados a um espectro de situações, pois as formas de trabalho atuam em diferentes etapas da produção de bens e de serviços, procuramos realizar entrevistas abertas com diferentes agentes do sistema produtivo, gestores e funcionários de hospitais e a esfera da administração pública, percorrendo assim cada um dos municípios.

Reunidos esses materiais empíricos - extraídos, sobretudo, da pesquisa de campo nas três cidades - os dados secundários e os materiais bibliográficos pertinentes, ingressamos o importante momento de operacionalização da pesquisa, que foi a elaboração do plano de redação dessa dissertação.

$\cos$

0 presente trabalho está dividido em quatro capítulos. No primeiro capítulo buscamos trazer a pertinência da discussão da saúde e dos equipamentos médico-hospitalares à geografia, assinalada como fenômeno técnico (Santos, 1996). Na mesma medida em que a noção de espaço pode contribuir para a interpretação do fenômeno técnico, é preciso verificar de que modo o espaço geográfico é por ele transformado.

Nesse sentido, as técnicas que autorizam as formas de cuidar da saúde hoje revelam fundamentos pretéritos. A prática clínica 
médica, que inicia uma demanda por instrumentos para "ver" os pacientes, e o universalismo do conceito de saúde aparecem como processos importantes da constituição técnica e política das formas modernas de obter saúde.

A ciência médica está sempre a revelar novos conhecimentos sobre as doenças, e isso fortalece seu papel numa sociedade em que a ciência é uma variável determinante. Entretanto, pela necessidade que a medicina tem de equipamentos, a legitimidade médica surge como instituição industrial quando o poder de algumas empresas se revela no controle da tecnociência à saúde.

Num tempo em que a medicina se faz por uma sofisticação técnica científica e informacional dos equipamentos médicos, perguntamonos a respeito dos agentes que têm poder sobre as variáveis, motores da divisão do trabalho, que transformam o território usado, subordinando muitos agentes. A essa altura, a saúde se mostra como mercado e os equipamentos médicos como bens econômicos.

No segundo capítulo, buscamos observar como o território usado constitui as existências sobre as quais o novo momento do modo de produção vem se instalar. Demos atenção à formação e dinâmica recente da indústria nacional ligada aos equipamentos médicos e aos processos da urbanização mobilizados por uma modernização seletiva.

Vê-se como estão imbricados esses dois processos, trazendo à tona a formação de um circuito superior marginal ligado aos equipamentos médicos. Da mesma forma, revela como a dinâmica do acesso à saúde responde a uma racionalidade vinculada à divisão territorial do trabalho hegemônico que faz ampliar as demandas que autorizam a existência de circuitos "marginais".

Nesse sentido, os hospitais aparecem como importantes dinamizadores da economia urbana, mas por uma dialética que tanto atrai para si muitos fluxos materiais e de mensagens quanto suas demandas mais modernas impõe uma difusão da produção daqueles agentes não-hegemônicos no território nacional.

No capítulo três demos atenção ao papel das normas como motor da diferenciação dos circuitos da economia urbana. Vimos que os equipamentos médicos são normas técnicas, assim como obedecem a uma lógica organizacional e política que responde aos mandamentos da competitividade global. 
A cientifização dos objetos e das formas de usá-los, em grande medida, controlada por agentes hegemônicos, repercute sobre a organização do sistema de saúde no país, assim como sobre os processos recentes da urbanização brasileira.

Seja pela ampliação de um terciário terapêutico ou pela intensificação dos serviços que os próprios equipamentos são demandantes, as formas de trabalho são transformadas enquanto as dinâmicas da saúde assumem papel na caracterização da diferenciação do espaço nacional.

Quando a lógica técnica e científica da medicina moderna encontra no Estado a condição para fazer valer uma lógica de mercado, a saúde se torna um meio de difusão de inovações, que não cessa de criar contradições entre acesso público e desigualdades socioespaciais.

A ampliação dos circuitos da economia urbana pelas próprias políticas públicas é observada em Campinas, Ribeirão Preto e São José do Rio Preto, cidades que já despontam na hierarquia urbana do país, além de serem tomadas nos programas estaduais e federais que se instalam criando novas compartimentações e solidariedades.

No quarto capítulo, veremos como a circulação imperativa do período da globalização e a manutenção necessária dos equipamentos médico-hospitalares são oportunidades para 0 surgimento de diferentes formas de trabalho nas cidades. Ressaltaremos a capacidade dos agentes hegemônicos em criar mecanismos de subordinação e dependência dessas formas de existência.

Nas cidades, o meio construído revela seu papel ativo na dinâmica do fenômeno técnico à medida que a completação do trabalho do circuito superior vinculado aos equipamentos médicos se faz em dependência do circuito superior marginal.

Nessa direção, procuramos compreender as diferentes atividades de produção de bens e serviços vinculadas aos equipamentos médicos no contexto em que estão inseridas, dando relevo a outras racionalidades que constituem a dinâmica da economia urbana. 
CAPÍtULO 1. A SAÚde E O ESFORÇO dE UM ENFOQUE GEOGRÁFICO

\subsection{A natureza técnica e científica dos cuidados médicos}

\subsubsection{O nascimento da instituição médica e algumas considerações sobre a ciência clínica}

Atentar para o caráter técnico-científico dos meios para se obter saúde hoje nos conduziu ao reconhecimento de uma gênese que tornou possível aparelhos sofisticados mostrarem formas interiores do corpo humano, anteciparem doenças, tratando-as com mais e mais precisão.

A passagem da medicina clássica para a medicina clínica traduz, de um modo geral, o senso de finitude descoberto na experiência da nascente cultura moderna. No momento em que o homem é Liberto do domínio de uma concepção sobre o sagrado, a experiência clínica anuncia o corpo humano como possibilidade de um discurso de estrutura científica.

o medo original, como chamou Z. Bauman (2006) o medo da morte, desempenhou papel fundamental nesse contexto do grande salto dado pela modernidade. Os estratagemas com os quais a inventividade humana buscou afastar, mesmo que temporariamente, a iminência dos perigos, encontrou na medicina um meio para lidar com esse novo pressuposto da vulnerabilidade da vida.

Parafraseando Ortega y Gasset (1939) quando nos convida a refletir sobre os atos técnicos como específicos do homem, naquele momento a medicina foi trazida no rol do repertório das novas necessidades do homem para viver e, nesse sentido, adquire papel científico diante da doença como problema também técnico.

0 advento de uma intenção técnica e científica, introduzida no cotidiano como desafio aos sofrimentos que poderiam se tornar evitáveis, desenhava o novo status social da medicina. Para tanto, é a regra classificatória própria às ciências da natureza que passa a sustentar a teoria médica, e mesmo a sua prática.

Ao se tornar uma lógica imanente de decifração semântica, o conhecimento da doença pelos sintomas dar-se-á por um discurso enunciável que, de algum modo, já era encontrado no reverso significativo do novo recorte médico do corpo. 
Neste universo da racionalidade médica, a linguagem médica com seu objeto aparece de tal forma anterior a doença que esta passa a ser vista como um ser de vida própria, e o doente aparece apenas como aquele em que a doença adquiriu traços singulares.

A noção de sintoma designa algo que cabe a alguém e remete àquilo que se tornava notável ao médico. Sem que possa se manifestar fora de um temperamento humano, a doença sustenta a implicação mútua entre o médico e o paciente.

A ciência médica definida antes de tudo como ciência da doença demonstra que, para que seu objeto científico se revele, o conhecimento deve se apresentar como uma questão inserida sob o ângulo preponderante da técnica, aquela que torna capaz de "ver" o paciente.

Desse modo, é a própria história de substituição de um meio cada vez mais artificializado que expressa o caráter da medicina enquanto possibilidade de intervenção sobre o corpo doente. Nesse sentido, o isolamento da doença aparece como traço epistemológico da condição do desenvolvimento da moderna medicina e do aprimoramento da capacidade de ação sobre as doenças.

Tal é sua vocação que o desenvolvimento de um arsenal de objetos revela a técnica como valor em si para os cuidados à saúde. G. Friedmann (1968), em seus estudos sobre a técnica, escreve:

"Ninguém dirá que a medicina não fez consideráveis progressos graças aos aparelhos que o clínico dispõe hoje para explorar o organismo e assegurar o diagnóstico. Entretanto, os próprios médicos notaram o perigo que representa esta acumulação de técnicas que tende a obliterar entre eles o sentido do doente, o conhecimento de suas necessidades, o tato psíquico" (Friedmann, 1968:30)

Não trataremos dessas questões, no entanto, apontaremos a medida da tecnificação da medicina como modo essencial e predominante dos cuidados à saúde, buscando indagar as tecnologias médicas contemporâneas sob o alerta de não negligenciar a indissociabilidade entre os objetos e as ações, isto é, entre a materialidade e o movimento da sociedade. 
J. Ellul (1968) já escrevia que a técnica inclui o homem em um verdadeiro novo meio natural, mas é M. Santos (1996:25) que nos chama a atenção quando assevera que as técnicas, mais do que o conjunto dos meios com os quais o homem realiza sua vida, ela cria espaço.

A partir do que B. Latour reconheceu como equívoco epistemológico da modernidade, isto é, a constituição de conceitos puros, procuramos nos aproximar de uma abordagem em que os equipamentos médicos são instrumentos, mas também, modos de fazer, capazes de, na sua evolução, revelarem um processo contínuo de redefinição das coisas.

Ao passo em que a medicina se constrói pelos seus novos meios de tratamento e cura, seu desenvolvimento enquanto saber técnico e científico não apenas amplia seus conhecimentos sobre as doenças, mas anuncia a descoberta de novos perigos e, ao mesmo tempo, novos recortes do corpo.

Nesse sentido, não é possível dizer que há uma natureza em si sobre a qual a ciência médica se debruçaria, do mesmo modo convém examinar que a medicina constitui um motor dos valores técnicos que acenderam nossa história moderna.

o progresso tecnológico promovido pelas técnicas provenientes das ciências aplicadas transformou significativamente o meio geográfico, dirá Ellul (1968:65). Desse modo, buscamos observar as transformações do espaço geográfico na medida em que os equipamentos médicos são inscritos num movimento de constante redefinição dos sistemas de objetos e de ações.

A distinção entre as técnicas particulares e o fenômeno técnico foi um esforço de método de alguns filósofos e geógrafos desde o início do século XX. Na geografia, essa concepção de que as técnicas não são apenas instrumentos ou máquinas, deve-se antes a Max Sorre (1948), que, àquela época, já nos explicava sobre uma noção de técnica mais abrangente.

Nessa direção, A. Fel, em seu importante artigo de 1978, escreveu sobre as relações indissociáveis entre a técnica e o fato geográfico. A pergunta pela natureza desse novo sistema de objetos e ações que constitui o meio geográfico do período atual e, igualmente constitui as atividades ligadas à saúde, é inseparável da técnica, enquanto fenômeno técnico. 
Em proveito dessas considerações iniciais sobre a natureza técnica e científica dos objetos médicos, propomos observar três aspectos do caráter das ações médicas: a natureza clínica da medicina e o novo papel do hospital; o status médico de posse de um saber de ordem administrativa e o imperativo técnico e científico do desenvolvimento da saúde.

No primeiro ponto, a clínica e o novo caráter do hospital, acompanhamos J. Labasse (1982:105) quando escreve que o hospital tem experimentado uma mutação na época contemporânea. Local de caridade aos idosos e indigentes até o final do século XIX, o hospital passa a integrar um novo contexto, agora apropriado à aprendizagem clínica e às aplicações técnicas que assegurariam o desenvolvimento da própria medicina moderna.

A definição da clínica pressupôs uma reorganização do campo hospitalar como ambiente para as lições sobre as doenças e a morte, de tal modo que era aberta a condição concreta de pôr à prova as verdades científicas da medicina, assim como de julgar a aptidão dos novos profissionais.

Ainda hoje esse caráter do hospital moderno sustenta-o como ambiente de um saber empírico. Contemporaneamente chamamos de pesquisa clínica essa serventia do hospital à prática da própria legitimidade da competência médica. No país, são os hospitais públicos de ensino que denotam tal processo.

Dessa maneira, o hospital torna-se o local onde a medicina aprimora sua capacidade aplicada aos doentes, daí ser este o ambiente em que os equipamentos médico-hospitalares encontram seu primado. Daí, também, poder justificá-lo como ambiente de alta complexidade tecnológica e médica.

Nessa direção, a noção moral do pobre era agora suplantada por uma definição econômica. A imputação do custo da doença aos próprios enfermos, dirá Labasse (1982:117), expressão da crítica ao sistema de caridades, abria um campo não apenas da medicina, mas de outros conhecimentos, com vistas a organizar o bem-estar e a saúde das populações.

Como instituição urbana, o hospital se afirmará como atributo da cidade. Lugar dos consumos coletivos, a cidade disporá do hospital como importante fator da dinâmica das economias urbanas, enquanto o mesmo passa se ocupar da prestação de serviços de saúde ao conjunto da população. 
0 aumento das necessidades das famílias e indivíduos, o surgimento da medicina clínica fundada nos exames, diagnósticos e a terapêutica eram novos imperativos que sustentavam uma medicina que ocupasse posto entre as atividades econômicas.

A experiência hospitalar moderna, entretanto, requeria atividades de múltiplos setores industriais, como a mecânica, a ótica, a eletrônica, a química. Ainda hoje atestamos que as demandas de um hospital se integram numa vida de relações, entendida para além do "setor" da saúde.

No segundo ponto em que podemos ressaltar uma constituição das ações médicas, vemos a consciência da doença se transformar em problema de natureza política, isto é, ao médico é atribuído um saber de ordem administrativa na sociedade.

No contexto da história européia, as epidemias percebidas como fenômeno coletivo da doença anunciaram um novo status dos médicos. Mas não apenas européia, pois vemos que esse processo se alarga, à medida que a ciência enquanto conhecimento universal, através dos novos sistemas técnicos, ganha relevância na constituição das sociedades ocidentais.

Enquanto a burguesia descobria a rentabilidade da tecnologia habilmente manipulada, o planejamento sucede como meio pelo qual - conhecimento sobre as doenças e suas prevenções adquiria notório papel na organização da sociedade.

Instituindo um poder enquanto saber técnico e científico, as sociedades médicas ganham um papel político. Ao integrar uma competência administrativa, os médicos mostram poder de decisão sobre formas de organização da sociedade, seus modos de alívio aos sofrimentos, no curso histórico dos meios para tratar a exclusão e a miséria.

Nesse sentido, se admitimos com Santos (1996:137) que cada período é "representativo da forma como a história realiza a promessa das técnicas", a medicina, ela mesma integrante desse meio técnico, tem também papel entre os determinantes dos modos de cuidar da saúde.

Nessa passagem, propomos o terceiro ponto de entendimento dessa constituição médica: o imperativo técnico e científico do desenvolvimento da saúde como abertura histórica a um processo de medicalização da saúde. Entretanto, esta medicalização só 
poderá ser compreendida a partir das dimensões políticas de um Estado.

No Brasil, quando falamos em medicalização da saúde (Augusto, 2000), referimo-nos ao processo histórico no qual a introdução crescente de inovações tecnológicas nas atividades em saúde tende a confundir o consumo de serviços médicos com a preservação da saúde, transformando os primeiros em demanda crescente para os serviços.

A ciência médica moderna abriu caminho para que uma certa concepção de saúde se estabelecesse de modo imbricado ao universo da tecnologia. Daí a preocupação de H. Gadamer (2006:120) quando diz que pouco se conhece sobre os segredos da nossa vitalidade ${ }^{1}$.

À medida que a saúde é encontrada sob a sombra desse horizonte positivo que estabelece 0 domínio da experiência médica e a estrutura da racionalidade que define as anormalidades e ameaças, a medicina tendeu a tornar a possibilidade da saúde uma questão de natureza técnica e científica.

A definição de saúde, fundada numa acepção das perturbações que ameaçam a saúde do homem, nos sugere a reflexão de que a relação entre a medicina e a saúde baseada nesse princípio de natureza clínica bem se ajusta com um processo contínuo de estímulos às inovações tecnológicas.

Próprio da ciência moderna, seja para descobrir/criar seus problemas, como para desenvolver suas "soluções", a medicina atual marca a inelutabilidade de um processo histórico crescente de tecnificação dos cuidados à saúde.

Nesse processo, a saúde que é um direito universal, apenas se realiza como tal quando os cidadãos se fazem valer efetivamente. E isso é atributo da singularidade da formação socioespacial (Santos, 1977).

${ }^{1}$ H. Gadamer (2006) se pergunta: qual será esse caráter oculto da saúde, já que ela não se declara a si própria, a não ser por um bem-estar que não se ocupa de si mesmo e não podemos verdadeiramente medir? 


\subsubsection{0 universalismo dos direitos sociais e o sistema de saúde no Brasil}

o processo de formação dos princípios clínicos e racionais que sustentam a medicina moderna aponta para um período histórico em que desmoronam antigas e triunfam novas legitimidades, que vêm responder às tendências à racionalização das esferas sociais.

Os direitos de cidadania, aclamados inicialmente na declaração francesa dos direitos civis, anunciam novas legitimidades que sustentam a conquista dos valores sociais. Nessa perspectiva, tal constituição fundamenta a possibilidade histórica de cada nação desenvolver meios de garantir o direito à saúde, individual e coletiva.

Sendo assim, é impossível imaginar uma cidadania que prescinda do território, pois o acesso aos bens e serviços essenciais encontra limites. Entre outros, podemos mencionar a desigual distribuição dos equipamentos públicos ou privados e a distinta condição de mobilidade das populações.

Como alerta Santos (1989:111) "o valor do indivíduo depende, em larga escala, do lugar onde está”. Nessa direção, compreender o território usado é um outro modo possível de ver como a cidadania se realiza.

Já P. Rosanvallon (2002) privilegia a compreensão dessa constituição dos novos valores a partir do liberalismo. Eixo da formação de uma nova cultura que atravessa o mundo moderno, o liberalismo não ascende como simples doutrina especializada, mas, no contexto de nascimento das liberdades individuais, transforma as bases políticas da defesa dos direitos do homem.

No momento histórico em que o contrato social expôs impasses à emancipação da atividade econômica, a superioridade política do mercado enquanto modelo de organização social toma forma, legitimando um novo vínculo social. Essa perspectiva é pertinente por mostrar que o direito à saúde não exclui o entendimento de que a saúde é também um bem econômico.

A cidadania, que nascia como lei da sociedade em que é reconhecido aos homens nascer e permanecer livres e iguais em direitos (Bobbio, 1992:93), representou um processo de racionalização das conquistas cidadãs. 
Nesse sentido, o território é instância material e formal do direito onde a localização dos serviços essenciais não pode ser deixada à mercê da lei do mercado, na medida em que se pretenda diminuir desigualdades sociais.

Vale entender essa imbricação das esferas política e econômica na constituição dos direitos, mas, sobretudo, estas na constituição dos territórios, pois os direitos sociais, como a saúde, somente podem se realizar por um arranjo territorial que transforme diferenças em equidades.

Dessa forma, os direitos do homem são históricos e seus direitos sociais ${ }^{2}$, apenas nascidos no século $X X$, pressupõem que os cidadãos tenham acesso a um conjunto de políticas e serviços que lhes possa assegurar um padrão de vida em que estejam protegidos contra a pobreza e a doença.

- Estado é o ator social com o qual um grande número de cidadãos conta para criar acesso aos bens e serviços sem os quais a vida é comprometida. Ortega y Gasset (1963:20) nos inspira quando diz que o bem-estar e não o estar é a necessidade fundamental para o homem.

A cidadania entendida a partir das políticas públicas, entretanto, não está orientada a um tipo paternalista de assistência às necessidades básicas dos cidadãos. Por isso que, do ponto de vista geográfico, a cidadania supõe levar em conta a situação do homem enquanto produtor e consumidor no interior de um território diferenciado.

No entanto, da mesma maneira, a cidadania pressupõe parâmetros cuja origem é externa ao lugar e à própria nação. Por isso nossa preocupação em refletir sobre a constituição técnica e científica dos objetos médicos.

Dessa forma, nosso intuito é observar o direito à saúde pela constituição técnica e política dos territórios. Isso é central no nosso caminho de método que pressupõe a análise dos equipamentos médicos não apenas como objetos, mas como meio geográfico.

\footnotetext{
${ }^{2}$ N. Bobbio (1992) define três fases sucessivas na constituição dos direitos, onde o nascimento dos direitos civis e políticos estiveram marcados no desenrolar dos séculos XVIII e XIX, enquanto os direitos sociais apenas começaram a ser estabelecidos no século XX.
} 


\begin{abstract}
"Ameaçada por um cotidiano implacável, não basta à cidadania ser um estado de espírito ou uma declaração de intenções. Ela tem o seu corpo e os seus limites como uma situação social, jurídica e política. Para ser mantida pelas gerações sucessivas, para ter eficácia e ser fonte de direitos, ela deve se inscrever na própria letra das leis, mediante dispositivos institucionais que assegurem a fruição das prerrogativas pactuadas e, sempre que haja recusa, o direito de reclamar e ser ouvido" (Santos, 1989: 8)
\end{abstract}

Sabemos que no período pós-guerra, mecanismos de regulação e direcionamento das políticas nacionais de saúde tomam forma num âmbito mundial. Novas instituições e instrumentos políticos supranacionais anunciam diretrizes ao desenvolvimento econômico, mas também social, a serviço de todos os povos.

A criação da Organização Mundial de Saúde (OMS) em 1948, como uma agência especializada da recém formada Organização das Nações Unidas, não nos deixa dúvida sobre o caráter universal do direito à saúde, e a legitimidade política dessa organização que influenciará cada país a enfrentar suas questões ligadas à saúde.

J. Habermas (2006), quando nos ensina sobre a racionalização da sociedade, onde a técnica e a ciência pervadem as esferas institucionais e as transformam, parece permitir nossa reflexão sobre o papel que teve o nascimento da Organização Mundial da Saúde para chamar a ciência médica a responder sua vocação moderna à saúde dos combatentes de guerra.

Desse modo, estaremos diante do que Latour (1994) chamou de híbridos, pois misturados são o conhecimento, o interesse, a justiça, o poder, o humano e o inumano, o global e o local - e separados estarão apenas enquanto a epistemologia da modernidade sustentar o equívoco das disciplinas puras.

0 enquadramento institucional que se justifica por se fazer funcionalmente necessário naquele contexto revela a técnica e a ciência médicas no destino dos cuidados à saúde, fazendo-a integrar os novos caminhos do desenvolvimento econômico e social.

Algumas conferências ${ }^{3}$ mundiais tiveram papel importante nos rumos dessa atualização do conceito de saúde. Entre 1960 e 1990,

\footnotetext{
${ }^{3}$ Em 1960, a pressão dos altos custos hospitalares naqueles países que haviam passado por uma
} primeira geração de reformas em seus sistemas de saúde, com extensão dos sistemas de 
a saúde deixa de ser definida apenas como setor sanitário e passa a depender de requisitos como: paz, educação, habitação, renda, justiça social e equidade.

Essa geração de reformas nos sistemas de saúde trouxe a promoção da atenção primária e a ampliação dos fatores de determinação das doenças como diretrizes aos países na obtenção de uma cobertura universal da saúde. Vale ressaltar que tal perspectiva da saúde é já imbuída da uma concepção econômica global.

No Brasil, vimos que defesa da democracia na década de 1980 esteve imbuída de fortes elementos dessa conjuntural internacional. A saúde, nesse sentido, representava os interesses não apenas da nação, mas, ao mesmo tempo, alinhava-se aos novos modelos no contexto global.

A nova Constituição Federal, promulgada em 1988, abriu-se para o nascimento de um novo paradigma de proteção social, em que foi ampliada a noção de direito social, apontado como responsabilidade do Estado, efetivando o direito à cidadania.

Em 1990, nasce o Sistema Único de Saúde, com a Lei Orgânica da Saúde (Lei n. 8.080/90 e n. 8.142/90), prevendo direito à saúde a todos os brasileiros. Os conceitos prescritos para a efetivação dos direitos são um tripé de princípios de

seguridade social, é reconhecida como problema a ser resolvido por um investimento em eficiência, agilidade e acessibilidade.

O Relatório Lalonde que, nos anos 1970 tinha a percepção dessa crise dos sistemas de saúde, vem instaurar as bases de um movimento de promoção da saúde. Definido que seria preciso intervir nos determinantes do adoecimento, o conceito de saúde passa a abranger a idéia de qualidade de vida, para além do foco em assistência médica.

Em Genebra, em 1973, a OMS realizou um Seminário Inter-regional sobre economia aplicada à saúde, mostrando que seu campo de atuação se ampliava. Em 1978, o evento realizado pela OMS e pelo Fundo das Nações Unidas para a Infância (Unicef), em Alma-Ata, no Casaquistão, marcou o reconhecimento dos direitos humanos para todos os povos do mundo em relação à saúde. Com representantes de 134 países, a Assembléia Mundial, precedida por diversas reuniões nacionais e regionais pelo mundo entre 1977 e 1978, definiu um ideal de saúde que interligou o desenvolvimento econômico, a estabilidade política e o desenvolvimento sanitário. Em 1986, a Carta de Ottawa, no Canadá, onde teve sede a I Conferência Internacional sobre Promoção de Saúde, representou um marco político. Esse documento concebe a saúde por meio de políticas públicas 'saudáveis', dando ênfase para mudanças no estilo de vida, reorientação dos sistemas de saúde e atuação da comunidade na gestão dos sistemas de saúde nos países. Essas informações a respeito da evolução histórica institucional dos eventos que redefiniram o conceito de saúde foram compiladas de Zanchi, M. T. e Zungo, P L., Sociologia da Saúde. Ed. Edusc, Caxias do Sul, 2008. 
universalidade, integralidade e equidade, os quais prevêem uma concepção da distribuição e acesso aos serviços de saúde ligada a critérios territoriais, com respeito aos seus usos.

A universalidade pressupõe que todos os brasileiros tenham acesso aos serviços de saúde, isto é, independente de onde moram e de suas condições materiais. Equidade significa que o atendimento a cada um deve prever igualdade, onde os recursos e serviços devem estar de acordo com a necessidade particular do paciente. A integralidade prevê uma interdependência de serviços distribuídos geograficamente por níveis de complexidade, de tal modo que o território nacional esteja todo coberto.

Para fazer com que isso aconteça, o Sistema Único de Saúde põe em prática a descentralização das responsabilidades de gestão, transferindo-as para os municípios, que passam a responder pelo serviço de saúde em função da atribuição hierárquica que os define dentro do sistema como um todo. Vale ressaltar que esta municipalização da saúde é um processo em curso.

A atenção à saúde no país está, portanto, segmentada em três níveis de complexidade do sistema: atenção básica, média complexidade e alta complexidade. As duas últimas estão organizadas em rede de assistência, dependente da capacidade resolutiva que o município possui em termos de infra-estrutura para atender os munícipes e aqueles que chegam de outros lugares.

Já no primeiro nível de atenção, as ações são tanto individuais, como coletivas e os procedimentos envolvem prevenção e tratamento, assim como encaminhamento médico para acessar as complexidades numa cadeia progressiva, em função de necessidade do paciente. No entanto, nos três níveis, há supervalorização do hospital como espaço de ações em saúde.

A descentralização, portanto, está ligada a uma hierarquização/regionalização dos serviços e, a qualidade deles, ligada ao nível urbano. Trata-se de uma organização territorial que supõe uma articulação entre os gestores municipais e estaduais na implementação das políticas.

A natureza da política de saúde implica uma racionalidade da distribuição dos equipamentos e serviços. Entretanto, segundo Ramires (2007), as pactuações entre as esferas federadas 
estariam orientadas por critérios políticos administrativos, nem tanto por uma compreensão conjunta e dinâmica entre o uso do território e os serviços de saúde.

Guimarães (2006:256) reconhece a complexidade do problema de articular a oferta de serviços com as necessidades da população. Sob a premissa de que os sujeitos são produtores de escalas geográficas, o autor concebe a saúde como síntese de múltiplas escalas e como instrumento de análise para articular os circuitos de reprodução de doenças e os circuitos de produção dos serviços.

A concepção do planejamento em saúde, observa Ramires (2007: 175), possui filiação com a noção de lugar central de Christaller (1933). As unidades que compõem o sistema de saúde estão alocadas em níveis crescentes de hierarquia, ao passo em que o planejamento da rede de serviços perde de vista a compreensão de que, nos países subdesenvolvidos, a capacidade individual de produzir e de consumir é dependente de sua localização (Santos, 2003:126).

A supervalorização do hospital como locus das ações de saúde não é apenas um dado da arquitetura do Sistema Único de Saúde, pois há uma demanda espontânea para os grandes centros (Albuquerque, 2006). Isso se dá pelas condições materiais do território, assim como por um dado cultural, em que a população acostumou-se a crer que no hospital está a cura.

Vale ressaltar que a previsão do acesso público e universal à saúde autoriza, em paralelo, a atuação em paralelo de uma complexa rede se serviços privados no território nacional. Essa liberdade à iniciativa privada, resultado das correntes e debates históricos culminados na Constituinte, trouxe a tona contradições à efetivação de um sistema de saúde universal

Gastão (2007) afirma haver uma polissemia da política do sistema de saúde no país, já que identifica uma convivência de dois modelos de atenção. Tais modelos são os sistemas nacionais, como em Portugal, Cuba, Inglaterra, e outros de caráter liberalprivatista, como ainda nos Estados Unidos.

0 sistema único de saúde, para Gastão (2007:1870), é um quase-híbrido dessas duas tradições. Concretamente não haverá os extremos, mas espectros de mesclas, reveladores de tensões na atenção e na gestão do sistema. Vale lembrar que o contexto 
histórico em que o Brasil logrou sua redemocratização esteve imbricado a introjeção no país do capitalismo neoliberal.

Nesse sentido, há uma síntese sanitária que é navegada, de forma contraditória, por uma política econômica e outra política de saúde. Mesmo que o sistema único de saúde represente a conquista efetiva da ampliação da oferta pública sob o princípio da integralidade, convive com uma expansão da oferta privada de serviços.

Ainda que pese à lei orgânica da saúde e os esforços para avançar dia a dia sobre as incompletudes do sistema único de saúde, o modo de tornar efetiva a política agrega os interesses corporativos e convive sob a égide de um tipo liberal de democracia.

Esse modelo misto do sistema de saúde no país termina, pois, por contribuir na concentração territorial da oferta de serviços. Modificando o valor dos lugares, a modernização tecnológica da medicina, por sua vez, propõe à economia urbana o aumento da demanda por serviços ligados aos equipamentos médicos.

Nessa direção, vemos a consonância do sistema de saúde nacional como o âmbito global em que a saúde é concebida. As reformas sanitárias contemporâneas - cujo modelo resultou do questionamento da política de bem-estar social nos países ricos, por não serem mais capazes de financiamento diante da nova configuração do sistema capitalista - encontram o Banco Mundial como importante agente na direção política da promoção da saúde.

Ao incorporar a sustentabilidade na pauta extra-setorial para - campo da saúde, o Banco Mundial ressalta o que em 1996 revela o Congresso patrocinado pela International Association of Health Policy.

Os sistemas sanitários, inclusive os mais eficazes, não são capazes por si só de garantir o alcance da manutenção de um nível satisfatório de saúde e bem-estar. Nesse sentido, o conceito de economia da saúde ganha forma e o Banco Mundial passa a avaliar, sobretudo, a rede hospitalar de alguns países.

Promovida pelo Banco Mundial a "economia da saúde" integra hoje as preocupações do país. A tendência crescente dos custos da saúde frente a recursos sempre limitados; a exigência cada 
vez maior dos usuários; e a identificação de muitas fontes de desperdícios na organização e prestação de serviços de saúde são justificativas para elaboração dessa economia da saúde.

Em 2008, pautado em um estudo avaliativo realizado durante 5 anos no país, o Banco Mundial (Bird) divulgou um relatório do "Desempenho Hospitalar Brasileiro", que reprovou os hospitais com a nota 0,34 , numa escala de 0 a 1 . Vale lembrar que o Sistema Único de Saúde possui 22 anos de existência.

Ao dizer que no Brasil o setor da saúde gasta mal, desperdiça e é mal gerido, o relatório revela que os hospitais, no centro do sistema brasileiro, são a maior fonte dos gastos, mas há pouca informação sobre gastos e desempenho. Ainda, que com serviços caros, nem sempre contribuem à boa saúde da população.

A pesquisa mostra que dos $R \$ 196,00$ bilhões gastos em saúde em 2006, 67\% foram para os hospitais (quando a recomendação da Organização para Cooperação e Desenvolvimento Econômico é de $55 \%$ ) e cerca de $30 \%$ desse total foi gasto com internações que não requeriam cuidados hospitalares.

Entretanto, o diagnóstico desse problema sistêmico - que os hospitais são centro ${ }^{4}$ do sistema de saúde e estes são caros e ineficientes - revela também a intenção da promoção de uma economia da saúde capaz de abranger um modelo de "governança" dos hospitais públicos.

A concepção de que os hospitais poderiam fazer muito mais com o que dispõem combina com o modelo de gestão autônoma dos hospitais públicos por Organizações Sociais ${ }^{5}$. Essa medida é já

\footnotetext{
${ }^{4}$ Os hospitais representam os elementos mais importantes e onerosos de qualquer sistema de saúde, ainda que haja considerações que ressalvam problemas crônicos nessa organização dos serviços de saúde. La Forgia e Couttolenc (2009) consideram que a gama de serviços oferecidos pelos hospitais - de tratamento clínico de alta tecnologia a cirurgias complexas, da contabilidade complexa a serviços básicos de hotelaria - torna sua administração complexa e cara e sua supervisão e controle extremamente desafiadores. Os países em que os hospitais são o centro do sistema de saúde e uma expressiva parcela dos gastos em saúde se destina à mantêlos, os hospitais podem se tornar caixas-pretas dispendiosas.

${ }^{5} \mathrm{O}$ Brasil tem introduzido inovações organizacionais no sistema de serviços de saúde de modo a tornar os hospitais públicos mais autônomos em relação a gestão direta do Estado. A partir de um contrato que estabelece a transferência da gestão a uma entidade que se torna responsável pela administração operacional e financeira do hospital público, o Estado de São Paulo introduz essa experiência no país, fato este que vem sendo valorizado pelo Banco Mundial como modelo bem-sucedido de aumentar a eficiência e a qualidade dos hospitais. Entretanto vale lembrar a polêmica jurídica que existe na medida em que há a transferência de bens e recursos públicos do sistema único de saúde para entidades privadas. Ainda que
} 
implantada no Estado de São Paulo e há projeto de lei sendo debatido no Congresso Nacional desde 2007 para ampliar esse sistema de gestão por fundações estatais de direito privado para o país.

Voltaremos a essa discussão mais adiante. Por ora, vale dizer que o sistema dos serviços de saúde no país constitui uma base material e organizacional sobre a qual não apenas a saúde como direito formal se revela, mas, sobretudo, a saúde como dinâmica do território usado por uma diversidade de agentes.

\subsection{0 meio geográfico e as tecnificação dos cuidados à saúde}

\subsubsection{Sobre os objetos técnico-médicos}

A medicina moderna tende a tornar indistinta a relação entre saúde e as concepções de progresso tecnológico da sociedade. Isso é, o aumento do coeficiente de tecnologia dos medicamentos e equipamentos médicos passa a sustentar a eficiência médica e a desejada melhoria da saúde e vida das populações.

Os medicamentos e os equipamentos médicos compreendem atividades produtivas de bens dos quais depende a medicina moderna. Nesse sentido, as medicina se torna envolvida numa sistematicidade global que, sob o ritmo das inovações industriais (Almeida, 2005), está expressa pelo poder de ação de grandes agentes hegemônicos.

Assim, os circuitos espaciais de produção e círculos de cooperação (Santos, 1985) de que constituem o poder desses agentes definem não apenas novas condições à saúde, mas, sobretudo, asseguram a realização do capital hegemônico pelo modo como regulam o processo produtivo e redefinem os usos do território.

Numa etapa histórica em que o modo de produção técnicocientífico manifesta sua virtualidade para se difundir de forma generalizada no planeta, o impacto incompleto dessa globalização atual se mostra na formação socioespacial e se torna revelador do agravamento de desigualdades.

mediante contratos de gestão, o debate em curso ressalta que essas entidades são selecionadas sem licitação. 
A. Sen (1992), quando se pergunta num importante artigo sobre a China, por que e como o crescimento econômico sucede em certos casos na redução da mortalidade e expansão da longevidade, explicita que não é que o crescimento econômico seja pouco relevante nem a solução completa, mas seria preciso avançar para medidas ligadas aos serviços de saúde e de acesso à assistência.

Nesse sentido, Almeida (2005) observou que a oferta de serviços de saúde no Brasil, tomados em seus diferentes graus de incorporação tecnológica, mostra que os objetos técnicos médicos, quais sejam os medicamentos, os equipamentos médicos e os próprios estabelecimentos de saúde, responde a uma lógica conjunta entre o Estado como as empresas.

Almeida (2005) nos revela que o comportamento da oferta de saúde, apesar da estrutura formal do sistema de saúde universal, responde a uma lógica tanto do Estado como das empresas. E a dispersão das unidades de alta complexidade, direcionada para as parcelas do território que são mais fluídas, mostra os limites de acesso determinadas por um sistema de movimento também seletivo.

Inegáveis e inúmeros são os avanços da medicina. Entretanto vemos que os homens permanecem diferenciados por uma combinação de fatores constitutivos de uma dinâmica social mais complexa. Ainda mais quando falamos nas regiões mais pobres, vemos quantos estão à margem dos avanços nos cuidados à saúde e modernidades médicas.

Nesse debate, a concepção de saúde não poderá ser reduzida. Sob o prisma das inovações tecnológicas, a saúde se torna estreita numa concepção tecnicista, que insiste em correlacionar as vantagens curativas da medicina moderna e os índices de determinada doença.

A saúde do homem responde sempre a um tipo de existência socialmente definida e essa concepção não poderá estar subentendida por uma vertente ideológica. Não convém que a relação entre tecnologia e saúde, conquista histórica para fazer face às fragilidades humanas, seja tomada por uma concepção restritiva do entendimento do movimento das sociedades.

Por intermédio do objeto técnico, a ciência nos toca em nossa vida cotidiana, observa Granger (1994:16). Dirá o autor que nosso período está marcado por laços indissolúveis do 
conhecimento científico e os saberes técnicos, que permitem repercutir tão prodigioso desabrochar de novos saberes na vida individual e social dos homens.

André Fel (1978) quando escreve que os objetos instalados na superfície da terra respondem às necessidades fundamentais dos homens, nos ajuda conceber a saúde como âmbito de análise dessa indissociabilidade entre o desenvolvimento da técnica e as transformações geográficas.

Ao longo do trabalho, buscamos observar o uso do território pelas atividades ligadas aos equipamentos médicos. Para encaminhar nossa análise das situações que são existência num lugar, propomos observar antes algumas características que marcam uma constante na orientação da própria medicina.

Isso porque, como veremos, é a partir de uma lógica da ciência médica - isto é, a crescente especialização dos cuidados à saúde e a divisão do trabalho por parte da indústria - que há a criação permanente de subsistemas técnicos hegemônicos, que se instalam sobre subsistemas preexistentes e definem, direta ou indiretamente, a dinâmica global e dos lugares.

\subsection{1.i A realidade sistêmica dos equipamentos médico-} hospitalares e a medicina como instituição industrial

P. George (1974) quando nos ensina sobre a técnica como criadora de um novo meio de vida, mostra que sua influência sobre o espaço se realiza pela ocupação do solo pelas infraestruturas das técnicas modernas e pela transformação generalizada a partir dos novos métodos de produção e de existência.

Ainda George (1974), escreve que o sistema espacial é redefinido permanentemente e, se antes os objetos se davam como conjuntos, hoje tendem a se dar cada vez mais como sistema. Em 1948, Sorre já assinalava o autocrescimento e rápida difusão da técnica como sistema.

Sabemos hoje que os nexos de dependência da técnica com a ciência revelam um processo contínuo de complexificação dos objetos. Graças a essa interdependência, a funcionalidade extrema, que os faz capaz de maior eficiência, amplia o potencial de criar sistemas técnicos. 
Ademais, a intencionalidade embutida nos objetos modernos nos convida a reconhecer não apenas a acuidade das execuções médicas, mas, pela localização precisa onde tais objetos se instalam, vemos a lógica de um acontecer que escapa ao lugar, pois responde a interesses distantes. 0 que torna evidente a relação dos objetos médicos com a técnica, a ciência e o novo momento da produção moderna.

A natureza intencional da técnica admite a aparição de objetos sempre mais avançados, como sugere Ellul (1954) ao dizer que a técnica antecede a ciência. A tecnociência contemporânea permite observar a subordinação da ciência às exigências do progresso tecnológico, tornando-a, como diz Ellul, um instrumento da técnica.

Vimos que o nascimento da ciência clínica no século $X I X$, como anúncio de uma consciência técnica dos cuidados à saúde, levou a medicina rumo à racionalidade instrumental dirigida à eficiência médica. É certo que a medicina moderna deste século XXI está marcada por conquistas antes impensáveis para a saúde.

Os avanços das ciências como a biotecnologia, a microeletrônica, são vantagens à vida, praticadas por uma ciência médica que se faz num meio técnico-científico informacional, a qual, da mesma forma, contribui ao aparecimento de novos instrumentos de trabalho e práticas sociais.

Vale dizer que a prevenção e a educação sempre foram correlatas à esperança de vida. Não obstante, jamais houve uma etapa na produção da história em que a obtenção da saúde estivesse conduzida por um modo de fazer universalizante, confundido com os poderes das tecnologias médicas.

Nesse âmbito, a ciência médica não será uma disciplina pura, mas sim compreendida na constituição do próprio meio geográfico atual onde, pela primeira vez na história, estamos convivendo com uma universalidade empírica6 (Santos, 1984), graças aos progressos conjuntos da ciência, da técnica e da informação.

\footnotetext{
${ }^{6}$ Santos (1996:92) assevera que “(...) graças aos progressos da técnica da ciência e da informação, a noção de totalidade permite um tratamento objetivo. Pela primeira vez na história da humanidade, estamos convivendo com uma universalidade empírica (Santos, 1984)." Explica o autor que "A planetarização das técnicas e da ação de comando por meio da mais valia, voltando ao velho marxismo, cria a possibilidade, junto com a evolução técnica, a visão do planeta com satélites etc., de ver o mundo, e de não apenas confiar na grande intuição do gênio filosófico, mas na história se fazendo empriricamente. (...)Existe primeiro no mundo dito
} 
Nesse sentido, é com prudência que vemos o progresso tecnológico como responsável por mudanças na estrutura mais ampla da morbidade das populações. Inserida num contexto fruto das condições historicamente produzidas, a medicina é apenas um elemento nesse processo em que a totalidade vai se fazendo mais densa e mais complexa.

A realidade sistêmica da técnica e a crescente universalização das tecnologias e procedimentos médicos são acompanhadas pela tendência apontada por G. Simondon (1989) ao destacar que as técnicas estabelecem entre si relações de dependência, graças à convergência entre seu projeto e sua construção.

Simondon (1958) mostra que esses objetos tornam-se objetos concretos pela incapacidade de cumprir funções diferentes àquela prevista. Nesse sentido, os equipamentos médicos podem ser vistos pela crescente hipertelia que assumem, à medida que a medicina se torna mais e mais especializada.

Daí que a individualização do organismo humano pelas descobertas mais acuradas da ciência médica representa, em grande medida, a individuação dos objetos médicos, tornados tão hipertélicos e demandantes de outros objetos que o sirvam em sistema.

Apenas como breve exemplo de equipamentos modernos, podemos mencionar o ultra-som, tão adequado para ver partes moles do corpo, mas esconder outras; e as ressonâncias magnéticas que apesar de altamente sofisticadas, apenas funcionam para ver 0 que não se move, o que dificulta que pacientes de Alzheimer sejam beneficiados.

Esses objetos médicos precisam de outros objetos que o acompanhe na sua operação, dentro e fora da sala de procedimentos, como objetos, soluções em gel e contraste específicos, camas especializadas, ar condicionado, computadores específicos. Que dirá numa sala de cirurgia?

tradicional, no qual você tem uma construção horizontal, uma construção e uma evolução a partir de elementos contíguos no espaço ou que têm alguma continuidade e cuja solidariedade funcional se deve em parte àquele espaço, àquele território, àquela área. A globalização muda isso, porque continua a existir esse processo, mas você tem outro processo que se dá brutalmente, rapidamente e externamente às realidades locais, horizontais, fundado sobretudo na informação e no dinheiro.” (Santos, 2004:40) 
Ainda, há outros objetos que são demanda do paciente, como roupas paramentais, fones de ouvido. E mais, é necessário que o lugar também seja especializado, pois alguns equipamentos se valem de princípios físicos, como campo magnético, radiação atômica, que exigem altos níveis de segurança.

Nesse sentido, um hospital, ou mesmo um estabelecimento de saúde onde haverá práticas médicas menos complexas, é, assim, um grande demandante de objetos técnicos que, por sua vez, se dão como famílias de técnicas.

Esse dado da multiplicidade de objetos específicos, e que se dão como sistemas de objetos médicos quando se trata de um procedimento, tornou nossa pesquisa sobre os circuitos da economia urbana para a saúde ainda mais rica, pois capaz de conter grande diversidade de agentes.

O surgimento de doenças iatrogênicas não é algo velado, mas reconhecido pela própria medicina. Definida por Illich (1975) como a epidemia de doenças provocada pela própria medicina, o autor faz uma análise mais profunda do termo ${ }^{7}$, tratando a medicina como instituição industrial.

o processo iatrogênico, dado pela natureza técnica da medicina moderna, causada por se realizar como um "medical establishment", é manifesto em três dimensões iatrogênicas: iatrogênese clínica, social e estrutural.

\footnotetext{
${ }^{7}$ I. Illich (1975), em sua crítica à medicina como instituição industrial, entende haver a partir dela um processo de medicalização da vida que é, por isso, uma ameaça à saúde. Ao reconhecer o homem das culturas tradicionais diferenciado do homem da cultura industrial, Illich fundamenta sua avaliação ao observar que, nessa passagem, foi entregue às instituições sociais a responsabilidade do homem cuidar da sua dor. Admite que o significado íntimo e pessoal da experiência da dor se transforma em um problema técnico e acrescenta: "toda doença é uma realidade criada no seio da sociedade. O que significa e a pronta resposta que suscita já têm história.” (p.152). Nessa direção, aponta a iatrogênese como uma epidemia de doenças provocadas pela própria medicina. Escreve: "A medicalização da vida é malsã por três motivos: primeiro, a intervenção técnica no organismo, acima de determinado nível, retira do paciente características comumente designadas pela palavra saúde; segundo, a organização necessária para sustentar essa intervenção transforma-se em máscara sanitária de uma sociedade destrutiva, e o terceiro, o aparelho biomédico do sistema industrial, ao tomar a seu cargo o indivíduo, tira-lhe todo o poder de cidadão para controlar politicamente tal sistema" (p.10). Nesse sentido, Illich irá dizer que esses três níveis da iatrogênese, em seu conjunto, contribuem para o comprometimento da capacidade de autonomia dos homens.

$8 \mathrm{O}$ termo medical establishment do original em inglês foi traduzido para o português como empresa médica por José Kosinski de Cavalcanti na edição Illich, I. 1975, Ed. Nova Fronteira, 2.ed, Rio de Janeiro.
} 
Tratamentos propostos a uma determinada enfermidade podem dar origem a outras moléstias, a isso o autor (Illich, 1975) chama de primeiro nível de iatrogênese a doença causada pela intervenção técnica médica, mesmo que prescrita de acordo com as regras da arte ${ }^{9}$.

Entretanto, é a própria medicina que vem neutralizar essa iatrogênese clínica, quando busca curá-la, adentrando, assim, outros níveis iatrogênicos ${ }^{10}$, pois o próprio sistema social passa a criar condições para que se dê uma colonização médica da saúde. Nesse sentido, há uma circularidade de consequências que alimenta a própria atividade médica e a legitima.

J. Baudrillard (1973:16) quando se refere ao sistema de objetos como dependentes de um sistema de práticas, assevera que "a descrição do sistema de objetos não se dá sem uma crítica à ideologia prática do sistema”. Daí nossa observação medicina como ciência aplicada, onde o processo iatrogênico terá importante papel na divisão do trabalho.

Observar essa relação híbrida entre os sistemas de objetos e de ações envolvidos na prática da medicina moderna nos faz alerta ao fenômeno social de penetração da ciência com a mediação da técnica. Mas, como assevera Granger (1994:16), não se pode confundir o pensamento científico e o saber técnico.

Nesse sentido, a criação das especializações médicas, dada pelos avanços científicos em diferentes áreas, e a tecnicidade hipertélica dos equipamentos médicos são processos

\footnotetext{
${ }^{9}$ Nesse sentido, o primeiro nível, a iatrogênese clínica, apresenta-se pelos efeitos secundários da terapêutica, a partir do contato médico-paciente na aplicação das regras que a profissão recomenda, como os medicamentos colaterais, as cirurgias inúteis, os acidentes hospitalares, todos consequências biomédicas que ampliam a necessidade de novas ações médicas.

${ }^{10}$ A iatrogênese social aparece como um segundo nível, a partir do qual a própria instituição médica está na origem dos sintomas clínicos, como a contínua descoberta ou nomeação de novas doenças, dada pelo avanço do conhecimento, o controle social pelo diagnóstico, dado pela crescente divisão médica do trabalho, os caprichos recomendados pela prevenção e a criação de mercados.

Já o terceiro nível iatrogênico da atividade médica é identificado num âmbito estrutural. Seria fundamentada pelo fato de que quanto mais as pessoas pensam ter necessidade de serem cuidadas, menos se revoltam contra o crescimento industrial, isto é, mais se torna limitada a possibilidade de interpretação e de reação autônoma do indivíduo em confronto com a precariedade da vida. (Illich, Ivan. 1975, Rio de Janeiro, Nova Fronteira).
} 
interdependentes que encontram nexos de causalidade com uma lógica de medicalização da saúde ${ }^{11}$.

Como veremos, hoje, a própria indústria de equipamentos médicos realiza pesquisa e desenvolvimento, assim como conta com médicos em seu sistema de inovação e, da mesma forma, realiza testes clínicos em hospitais públicos incentivados pelo próprio Estado.

Esse caminho nos permite entender que medicamentos, médicos e hospitais são elementos de um determinado sistema de ação cuja natureza técnica é produtora de objetos e demandas, as quais são justificações para que novos esforços tecnocientíficos sejam empenhados.

Num movimento que tende a reduzir os cuidados à saúde a seus próprios padrões e exigências, estes progressos resultantes de crescentes divisões do trabalho fazem ampliar as necessidades que, direta ou indiretamente, estão asseguradas pelo desejo genuíno do homem de bem viver.

Essa duplicação do esforço, determinada pelo efeito de que cada avanço prático corresponderia a um distanciamento cientificamente determinado do objetivo de se alcançar os fatores da saúde, como uma programação de contra-senso ligada à saúde, foi chamada por Illich (1975:86) de nêmesis industrial.

Tal processo foi alertado também por Ellul (1954) quando observa o aparecimento das técnicas como motor e fundamento da economia. Também Simondon (1989) dirá que a tecnociência atrela técnica e economia por impor eficiência e produtividade. Gaudin (1999:51) também nos convida a pensar a saúde pelos seus nexos

\footnotetext{
${ }^{11}$ A iatrogênese devida à dominação do médico sobre a linguagem do doente; a iatrogênese devido a um tipo de controle social pelo diagnóstico, onde as diferentes idades são submetidas à uma categorização que prevê um particular de ingerência terapêutica; a iatrogênese devido à medicalização do diagnóstico precoce, como potenciais criadores de expectativas não fundadas; a iatrogênese que cria certa confusão da prevenção com a previsão das doenças, disseminando seguros de vida, de saúde e de toda ordem; esses são exemplos de um processo de medicalização da saúde. As críticas implacáveis de Illich à medicina em sua forma institucional são relativas a uma época (escreve seu livro em 1975) em que muitos avanços permitidos pelas novas tecnologias da informação, pela biotecnologia, pela genética, pela física, pela microeletrônica, entre outros, não havia se instalado. Nesse processo de medicalização da saúde, onde os cuidados são devotados às capacidades da medicina, vale ressaltar o poder da empresa médica em determinar não apenas as condições possíveis à saúde, mas também as necessidades humanas para tratá-la. Daí nossa preocupação em perceber a abertura desse vão mercantil quando a medicina termina por se fazer apenas na dependência de uma instituição industrial.
} 
com as intencionalidades mercantis quando escreve sobre $\mathrm{da}$ melhora da qualidade de vida economizando o $\mathrm{PIB}^{12}$.

Daí nosso passo para observar o papel da especialização médica como um processo de crescente divisão do trabalho. G. Canguilhem (2005) quando assevera que "foram deslocados os locais de observação e de análise das estruturas orgânicas suspeitas, em função de aparelhos e de técnicas próprias ou emprestadas $^{13}$, anuncia a respeito desse processo de repercussão abrangente.

\subsubsection{Cientifização dos equipamentos médico-hospitalares e divisão territorial do trabalho}

Atualmente, a produção material do objeto se dá depois de haver a produção científica. Como observou Santos (1996)

"O objeto é científico graças à natureza de sua concepção, é técnico por sua estrutura interna, é científico-técnico porque sua produção e funcionamento não separam técnica e ciência. E é também informacional porque, de um lado, é chamado a produzir um trabalho preciso - que é uma informação - de outro, funciona a partir de informações.” (Santos, 1996:171).

A medicina, em seu avanço científico, é um tipo de suporte à cientifização dos equipamentos médicos, mas é também assistida por eles em suas pesquisas. Estes instrumentos se tornam objetos informados, ao mesmo tempo em que a indústria os cria como um sistema técnico que alarga seu alcance pelas demandas de uma sistemática tecnocientífica.

Os equipamentos médicos, prenhes de finalidades pragmáticas, se tornam sistemas técnicos rígidos. 0 sistemismo imperativo desses objetos, com efeito, termina por diminuir as possibilidades de que a saúde seja produzida de outro modo. As

12 "Cheguei a me perguntar se as economias ditas desenvolvidas, em lugar de exaltar a crença em seu PIB, não fariam melhor em se perguntar como oferecer uma melhor qualidade de vida economizando o PIB. Nas grandes cidades, em todo o caso, os engarrafamentos, a poluição, as disfunções generalizadas são geradoras do aumento do PIB em razão das despesas que provocam (combustíveis, saúde...) e que deveriam ser consideradas como negativas." (Gaudin, 1999: 51).

${ }^{13}$ As doenças foram sucessivamente localizadas no órgão, no tecido, na célula, no gene, na enzima e, de modo sucessivo, trabalhou-se para identificá-las na sala de autópsia, no laboratório de exames físicos (ótico, elétrico, radiológico, ultra-sonográfico, ecográfico) e químicos ou bioquímicos (Canguilhem [1970], 2005:25) 
demandas desses objetos à saúde estão envolvidas numa racionalidade instrumental mais abrangente.

Daí que se a divisão médica do trabalho expressa, por um lado, a descoberta de novas doenças, por outro, há o despontar de um complexo de atividades médicas, evidente pelo crescimento de serviços de exames diagnósticos e novas possibilidades de tratamentos.

Essa mirada para o fato de que a medicina é criadora de necessidades médicas parece-nos pertinente ao estudo das atividades ligadas aos equipamentos médicos, pois nos leva à reconhecer alguns mecanismos que constituem o fenômeno da crescente divisão do trabalho ligada aos cuidados da saúde.

Podemos dizer que nascem e se diversificam doenças, pululam objetos e procedimentos médicos, multiplicam-se atividades produtivas ligadas aos equipamentos médicos. Essa perspectiva, na qual se densificam e diversificam divisões territoriais do trabalho, mostra, da mesma forma, a ampliação dos consumos em saúde.

É cada vez mais especializado o uso de um arsenal de objetos, produzidos por uma medicina que se especializa. Dessa forma, a crescente divisão do trabalho, dada pelo processo progressivo e, hoje, acelerado de incorporação de novas técnicas, implica disputas pelo uso do território.

Nesse sentido, a diversificação dos objetos que tornam capazes novas formas de diagnóstico e tratamento é revelada pelo crescimento dos serviços de procedimentos médicos, onde as atividades são também reveladoras da densificação de um terciário terapêutico.

No Brasil, o aumento dos estabelecimentos de saúde públicos e privados demonstra os objetos técnicos demandados. Quanto maior a complexidade médica que o estabelecimento é capaz, maior o espectro de objetos técnicos que autoriza suas ações. 
GRAFICO 1 - Número total e por esfera administrativa dos estabelecimentos de saúde sem internação - Brasil, 1976 - 2005

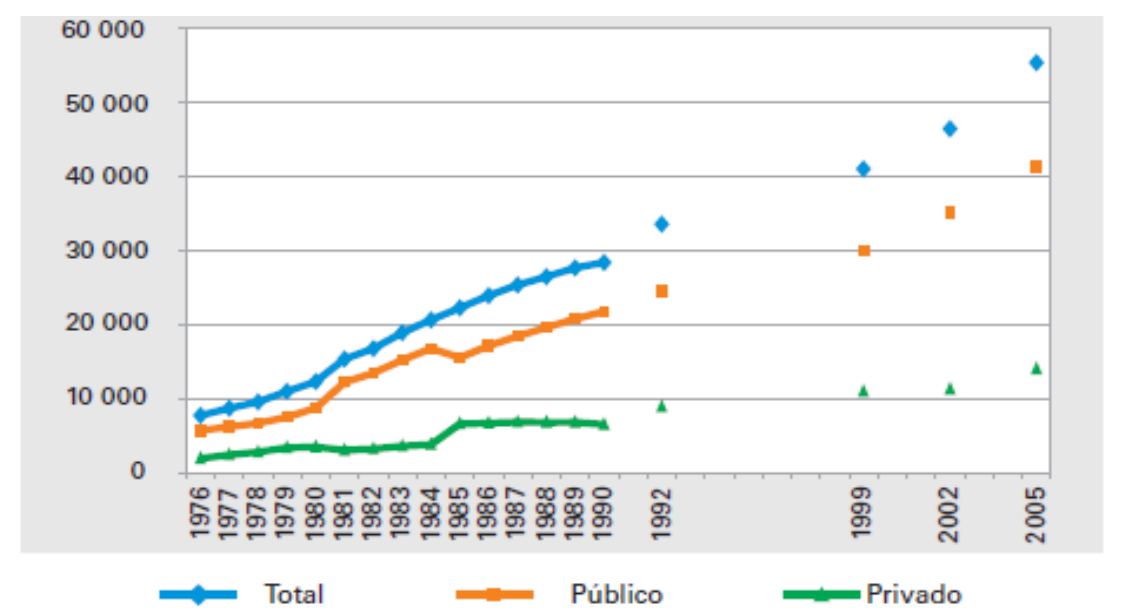

Fonte: IBGE, Diretoria de Pesquisas, Coordenação de População e Indicadores Sociais, Pesquisa de Assistência Médico-Sanitária 1976/2005

A economia urbana ligada aos equipamentos médicos revela em algumas cidades a multiplicação não apenas da oferta de serviços, mas da produção e do consumo relacionados à saúde. Em Campinas, Ribeirão Preto e São José do Rio Preto, vemos crescer a divisão do trabalho ligada à saúde.

Nesse sentido, seja pelos serviços que são prestados aos cidadãos, seja pelo serviço que é uma demanda própria dos equipamentos, a saúde integra o fenômeno mais abrangente da terceirização da economia e do emprego na urbanização brasileira.

Como mostra a seguir o mapa ${ }^{14}$ sobre a centralidade urbana em termos de oferta de serviços de saúde, podemos apontar Campinas, Ribeirão Preto e São José do Rio Preto como importantes cidades do Estado de São Paulo na configuração do sistema de serviços de saúde públicos e privados no país.

14 A centralidade urbana avaliada em termos da oferta de serviços de saúde destaca, no primeiro nível, as duas metrópoles nacionais com maior porte e complexidade, São Paulo e Rio de Janeiro. O segundo e o terceiro níveis correspondem aos centros capazes de prestar atendimento mais complexo, distinguidos entre si pelo tamanho. No segundo, estão as áreas das maiores capitais estaduais: Belo Horizonte, Recife, Fortaleza, Porto Alegre, Curitiba, Goiânia, Salvador, Belém e Manaus, bem como Brasília e Campinas. No terceiro nível, além de dez capitais estaduais (Vitória, João Pessoa, Cuiabá, Campo Grande, Maceió, Teresina, São Luís, Natal, Aracaju e Florianópolis) destacam-se grandes centros regionais tradicionais, como Campina Grande, Juiz de Fora, Uberlândia, Ribeirão Preto e Londrina, São José do Rio Preto, entre outros. (IBGE, Regiões de Influência das Cidades, 2007). 
MAPA 1 - Centralidade urbana em relação à oferta de serviços de saúde - Brasil, 2005

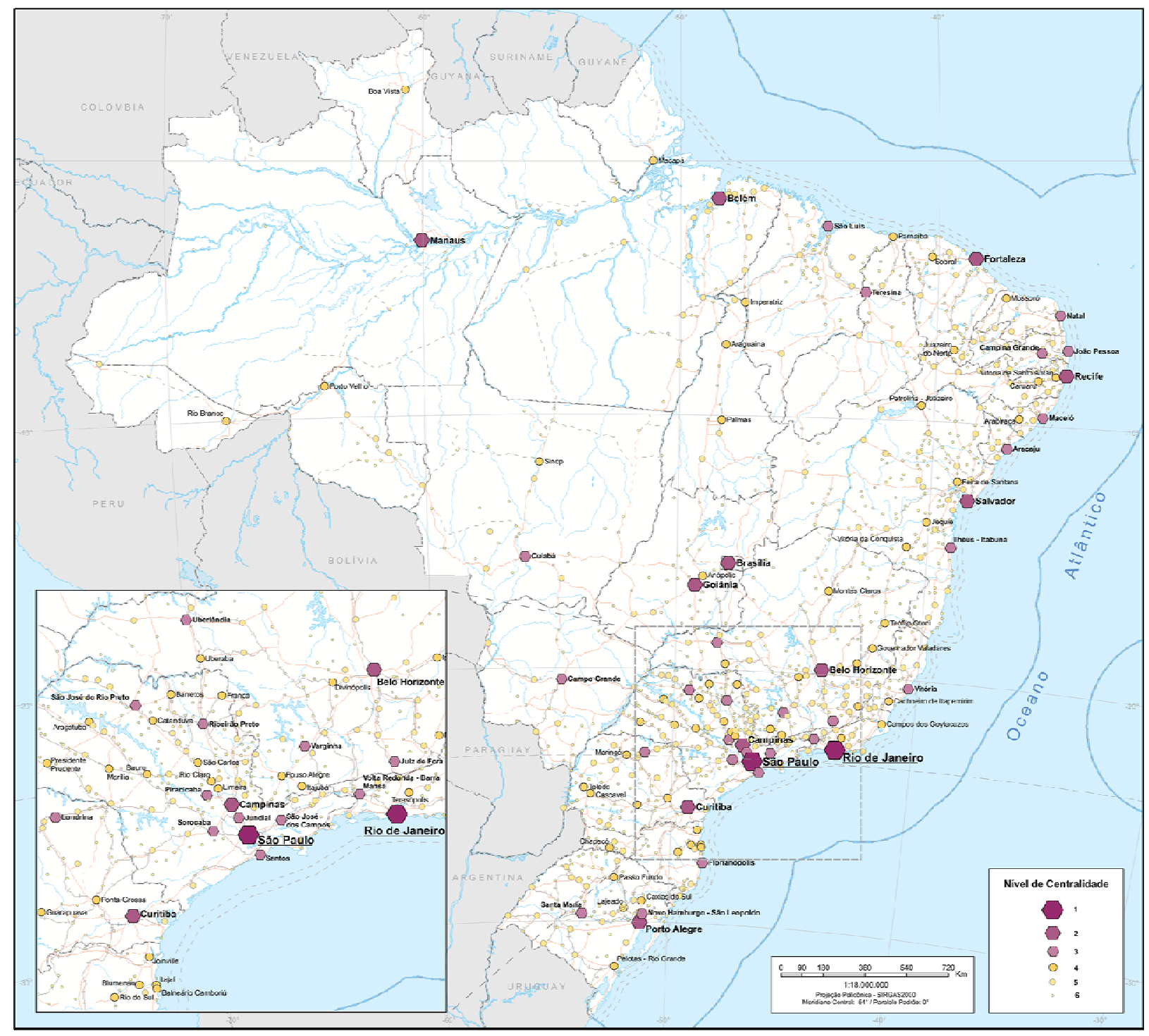

Fonte: IBGE. Região de Influência das Cidades, 2007, p156, mapa 60. Elaboração: IBGE, Diretoria de Pesquisas, Coordenação de População e Indicadores Sociais, Pesquisa de Assistência Médico-Sanitária 2005; Informações de saúde. Epidemiológicas e morbidade. Morbidade hospitalar geral por local de internação 2005. In: Ministério da Saúde. DATASUS. Brasília, DF, 2005.

Os equipamentos médicos, diferentemente dos medicamentos, se mostram como objetos fixos nos lugares, daí serem dos pacientes a mobilidade sem a qual não poderá acessar a oferta do serviço. Com efeito, esse atributo normativo do território se torna fator de diferenciação das economias urbanas vinculadas à promoção da saúde.

Impondo sucessivas mudanças na forma e no conteúdo dos meios de se obter saúde, os avanços tecnocientíficos vêm aumentar a espessura dos subespaços correspondentes. 0 território usado pelos diferentes agentes sociais manifesta a existência de 
múltiplos contextos e combinações mais ou menos dependentes da produção hegemônica da saúde.

Diferentemente de contar apenas com as concepções institucionais e consensos universalistas, o conceito de saúde compreenderá uma perspectiva intrínseca ao processo de modernização, no qual o uso do território é revelador da dinâmica que valoriza relativamente os lugares.

Nesse sentido, apesar de universal, os sistemas técnicos que envolvem as atividades em saúde são manifestações da particularidade com que o desenvolvimento desigual revela processos intrínsecos à forma como cada povo valoriza o movimento das técnicas.

Entretanto, sabemos que, se antes a diversidade das técnicas correspondia à diversidade de lugares, hoje, a obediência à eficácia, e não mais a uma diversidade de motivos inseridos em seus próprios contextos, tende a criar uma unicidade da técnica universal, tornando-a universal por meio da convergência de seus sistemismos.

Para Ellul (1968:81), o processo racional que submete a técnica aos mecanismos de divisão do trabalho, de criação de padrões e normas de produção, entre outros, autorizou a transmissão das técnicas para lugares longínquos. Nesse sentido, a instituição médica é tanto um efeito como motor nesse processo mais abrangente.

As atividades ligadas aos equipamentos médicos-hospitalares são, portanto, demandas que não param de crescer. Nesse sentido, vemos que não basta mencionar a saúde como atividade prestadora de serviços, pois tal oferta dependerá, em grande medida, da produção dos bens à saúde, num contexto em que a população está ligada a ele para produzir e consumir.

Desse modo, a saúde se mostra por uma dimensão em que é, ela mesma, um consumo que, embora seja demanda constante, é diferenciada nos lugares, mas também é uma produção que, apesar de estar fortemente influenciada pela hegemonia da produção moderna, permite a multiplicação e diferenciação de atividades. 


\subsection{2.i. Sobre a distribuição desigual dos serviços de saúde}

0 crescimento da produção de exames digitais mostra a transformação por que passa o saber do médico. Se antes o paciente era observado por procedimentos manuais, hoje, na era informacional, são grandes máquinas, verdadeiros autômatos, que se interpõem aos sentidos do médico, assim como a sua formação profissional.

Os equipamentos de imagem, hoje crescentemente digitais, alteraram completamente a relação com os sintomas do paciente, permitindo que objetos técnicos sejam novas formas de se relacionar com as doenças.

o gráfico a seguir mostra um gráfico em que se apresenta certa diminuição dos equipamentos de raio x no Brasil entre 1999 e 2005, com destaque para as Regiões Sudeste e Sul. Enquanto a figura 4 nos apresenta o aumento dos tomógrafos em todas as regiões do país.

GRAFICO 2 - Distribuição dos equipamentos de Raio-X por 100 mil habitantes, segundo as Grandes Regiões - Brasil, 1999 - 2005

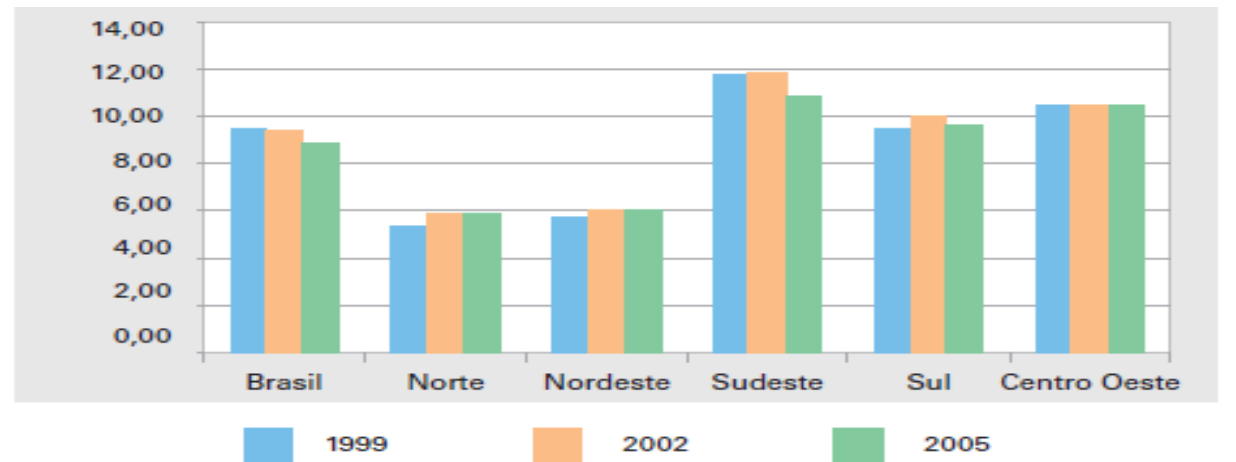

Fonte: IBGE, Diretoria de Pesquisas, Coordenação de População e Indicadores Sociais, Pesquisa de Assistência Médico-Sanitária 1999/2005.

GRAFICO 3 - Distribuição dos tomógrafos por 100 mil habitantes, segundo as Grandes Gegiões - Brasil, 1999 - 2005

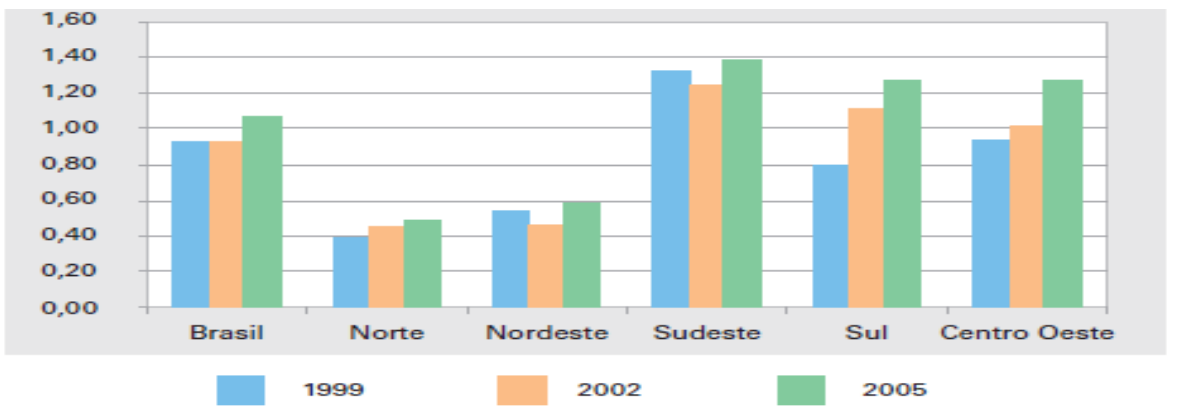

Fonte: IBGE, Diretoria de Pesquisas, Coordenação de População e Indicadores Sociais, Pesquisa de Assistência Médico-Sanitária 1999/2005. 
Diferentemente dos intermediários humanos, os equipamentos médicos de imagem permitem procedimentos que tornam mais eficiente a tarefa médica, entretanto se multiplicam pela concepcão atual que insiste dizer que as imagens não mentem, como escreveu Bauman (2006:29).

A palavra clínica, cujo sentido já fora à cabeceira do doente, designa agora o lugar onde se vai para saber, por meio dos objetos cada vez mais capazes de ver, se temos problemas de saúde, e se temos o direito a tratamentos.

Os objetos têm cada vez mais um discurso que vem de sua estrutura interna, estrutura essa, ensina Santos (1992:54), que revela sua funcionalidade extrema e cujos fins nos escapam pela intencionalidade que os define e também pela lógica de sua instalação.

GRAFICO 4 - Distribuição de equipamentos por 100 mil habitantes, segundo as Grandes Regiões - Brasil, 2005

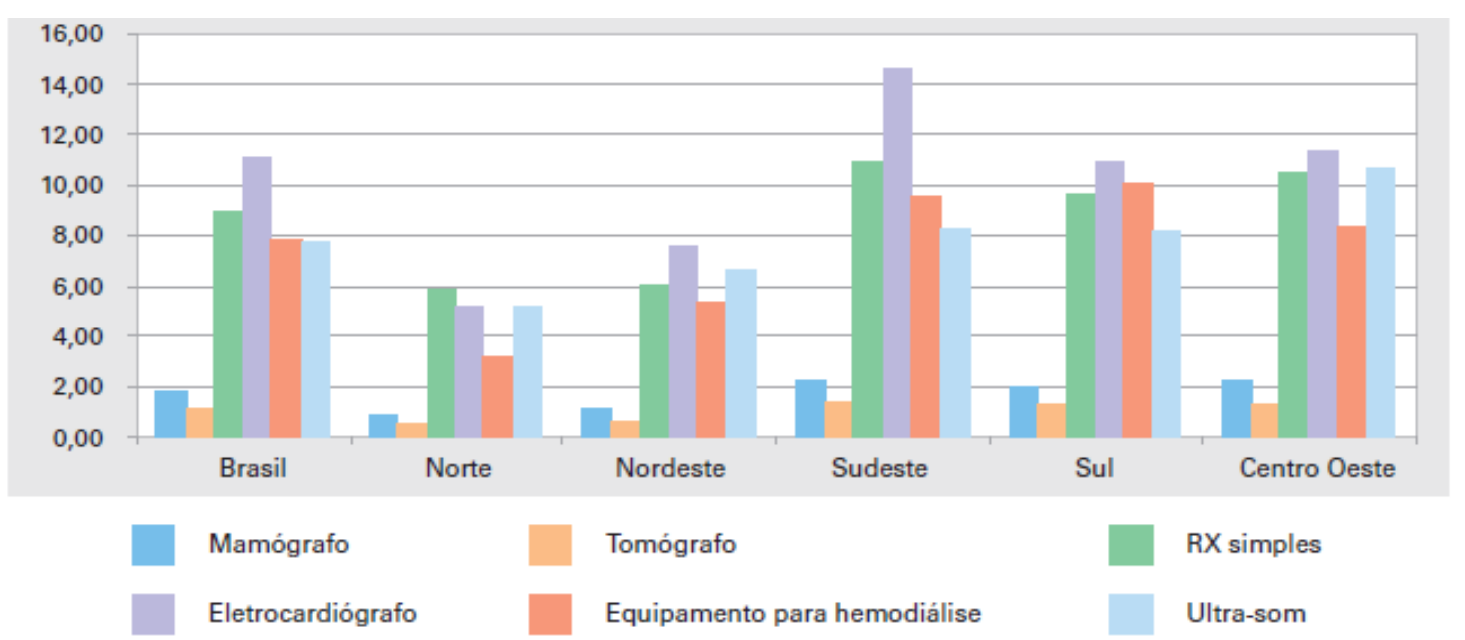

Fonte: IBGE, Diretoria de Pesquisas, Coordenação de População e Indicadores Sociais, Pesquisa de Assistência Médico-Sanitária 1999/2005.

Essa aparelhagem aprimorada, sejam tomografias ou mesmo agulhas, está justificada pelo seu desempenho em acuidade diagnóstica e terapêutica. No entanto, à medida que essa sofisticação se faz por uma lógica que beneficia ações individualizadas de atenção à saúde, aumenta o peso organizacional $^{15}$ do sistema de serviços quando se pretende universal.

${ }^{15}$ A rápida transformação tecnológica na saúde vem sugerindo desafios administrativos não apenas a cada estabelecimento hospitalar, mas, sobretudo ao sistema de saúde como um todo, 
Nesse sentido, a tendência a que as tecnologias médicas personalizem os cuidados à saúde foi observada por Augusto (2000:160). Com devido reconhecimento desse avanço para o indivíduo doente, a questão se coloca quando a estrutura de gastos hospitalares ${ }^{16}$ nem sempre se associa a melhora do nível de saúde da população.

A especialização médica é anúncio da particularidade do tratamento, enquanto a especificidade dos exames vem mostrar a precisão dos equipamentos na ação sobre os indivíduos. Da mesma forma, aumenta a exigência de trabalho científico para utilizar os equipamentos, seja por parte dos médicos ou dos outros profissionais da saúde.

Esse processo que repercute sobre a organização do sistema de saúde, isto é, o aumento da personalização do cuidado à saúde, parece mais responder aos modelos dos países desenvolvidos, onde é possível dizer que há uma transição epidemiológica ${ }^{17}$ efetiva e que problemas de saúde básica não persistem como aqui. Ainda assim, vemos que o país tem feito avanços significativos na redução das taxas de mortalidades por doenças infecciosas e parasitárias.

TABELA 1 - Distribuição de Doenças infecciosas e parasitárias, por Grande Região - Brasil, 1990 - 2006 (porcentagem no conjunto total das causas de morte por região)

\begin{tabular}{l|l|l|l}
\hline \multicolumn{1}{c|}{ Regiões } & $\mathbf{1 9 9 0}$ & $\mathbf{1 9 9 9}$ & $\mathbf{2 0 0 6}$ \\
\hline Norte & 15,15 & 7,66 & 6,89 \\
\hline Nordeste & 10,6 & 7,66 & 5,49 \\
\hline Sudeste & 4,76 & 5,44 & 4,67 \\
\hline Sul & 3,99 & 4,11 & 4,0 \\
\hline Centro-oeste & 9,33 & 6,71 & 5,35 \\
\hline Total & 6,23 & 5,83 & 4,92 \\
\hline
\end{tabular}

Fonte: Ministério da Saúde - DATASUS Informações de saúde

onde sua pretensão universal impõe uma adaptação organizacional num contexto sempre mais e mais moderno. Daí podermos compreender um pouco mais o que dissemos antes sobre o diagnostico do relatório do Banco Mundial a respeito do desempenho hospitalar no Brasil publicado em 2008 e o modelo de gestão hospitalar por parte das Organizações Sociais.

${ }^{16}$ Vimos acima que os hospitais no Brasil são transformados em centro nervoso do sistema de saúde, sendo que pela sua densidade de objetos técnicos e recursos humanos justificam que sejam responsáveis por quase $70 \%$ dos custos da saúde, todavia, muitas internações, que são interpretadas como a principal fonte dos gastos em prestação de serviço, são desnecessárias, enquanto, podemos dizer há um desprestígio das ações em saúde coletiva.

${ }_{17}$ Transição epidemiológica é descrita pelo aumento da expectativa de vida da população, dada pela melhora da qualidade de vida, o que se revela num envelhecimento da população, mas também pela mudança no perfil das doenças, dada pelo aumento das doenças crônicas degenerativas e dos acidentes de trânsito na medida em que há uma diminuição das condições de doenças causadas por problemas sanitários. 
Em 1990 a porcentagem da mortalidade proporcional ao conjunto das causas de morte causas era 6,23. Já em 2006 essa proporção é de 4,92. Vemos os importantes avanços que o país tem conquistado em relação à diminuição das mortes por doenças infectoparasitárias, muitas causadas por precárias condições sanitárias.

Atualmente, o Programa de Saúde da Família e as campanhas de imunização deverão incrementar ainda mais essa redução, considerando o papel que têm na integralidade dos serviços e na universalização da saúde no país.

Já na figura seguinte, vemos o conjunto das causas de mortalidade no país - sendo essas as sete divisões classificadas no país - onde é possível verificar uma redução relativa de todas elas, com exceção das neoplasias e demais causas definidas.

GRAFICO 5 - Porcentagem da mortalidade por tipo de causa de morte Brasil 1990 - 2006

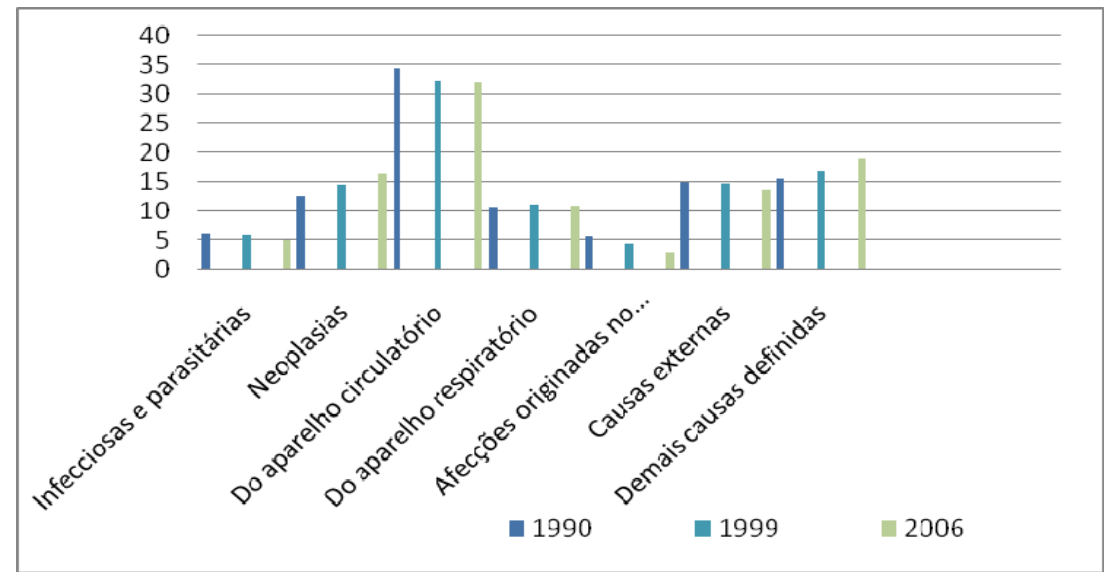

Fonte: Ministério da Saúde - DATASUS - Informações Demográficas e socioeconômicas

A ampliação da cobertura da saúde no país e dos níveis de atendimento médico tem feito grandes avanços nesses anos de sistema único de saúde. A atenção hospitalar básica está disponível praticamente em todo o território nacional e poucos são os municípios desarticulados de uma rede de assistência. (Oliveira, et al, 2004).

Nesse sentido, vemos o esforço de atenção universal à saúde. Entretanto, as desigualdades regionais no acesso, que se dão em relação aos serviços mais complexos, fragilizam o ideal de equidade do atendimento. 
Alguns estudos apontam a tendência à redução dessas desigualdades regionais (Teixeira, 1999; Travassos et al, 2000), mas esse processo tende a ser muito lento, pois a distribuição de recursos termina por reforçar as desigualdades.

A necessidade que tem um hospital de equipamentos de toda ordem, assim como de recursos humanos variados e serviços diferenciados, não só para os pacientes, mas para seu próprio funcionamento, mostra o poder de atração dos fluxos de serviço de alta complexidade.

Oliveira (2000) nos mostra a situação das redes de alta complexidade, onde apenas um pequeno número de centros presta atendimento e cerca da metade dos municípios brasileiros está desarticulada. Como no caso de cirurgia cardíaca, 54,5\% dos municípios está desconectada e $43 \%$ no caso de neurocirurgia, com a ressalva de que o último decorre, em maior medida, de situações de emergência (Oliveira, et al, 2004:400).

Sabemos que são raros os que se beneficiam de uma medicina a base de tecnologias altamente eficientes e, ainda que o acesso às tecnologias modernas aumente, não é por uma medida de tempo cronológico que veremos maior democratização desse bem coletivo, quando o problema se revela complexo e sistêmico.

\subsection{2.ii. Necessidades médicas e estratégias de mercado}

Pela característica e difusão dos objetos médicos há uma tendência à universalização da medicina moderna, todavia, na medida em que a técnica é, ela mesma, um meio, vemos que não são apenas objetos, mas sim um certo modo de fazer saúde que se universaliza.

Vemos que antigas formas patológicas tenderam a desaparecer com as transformações do meio geográfico e novas morbidades surgiram com o advento do meio técnico-científico e informacional. Nesse sentido, da mesma maneira que as doenças são históricas, também são geograficamente definidas. Expressão dos híbridos de Latour (1994), as doenças são indissociáveis do meio geográfico.

Nesse sentido, se a doença hoje está, por um lado, dependente do ato médico que se encarrega do paciente, por outro, há o perigo de que numa sociedade capitalista as condições de vida e 
saúde estejam absorvidas por um processo de mercantilização dos bens coletivos.

Os meios de obtenção de saúde hoje são prenhes dos objetos fabricados por grandes indústrias hegemônicas. Isso porque são eles próprios agentes da pesquisa. E, na medida em que vivemos um apelo ao bem estar, a saúde, íntima dos avanços da ciência, torna esses agentes determinantes das novas e complexas divisões territoriais do trabalho.

Algumas marcas possuem força para fazer com que seus produtos vendidos em todo planeta pareçam únicos e especiais, observa $R$. Sennet (2006:133). o discurso do uso, pois, confunde-se com o discurso da sedução ao consumo.

As atuais estratégias de consumo nada têm a ver com a alienação das consciências como antes, dirá Lipovetsky (2005). Hoje se identificam com a repetida multiplicação de possibilidades de escolhas, a partir da oferta ao indivíduo de uma gama de combinações sob medida.

Aqui, não fazemos menção aos simples consumos dos pacientes que, quando podem, preferem a garantia médica que prometem os equipamentos mais modernos, mas, sobretudo, aos consumos dos médicos, das clínicas, dos hospitais, das prefeituras, todos indissociáveis ao aumento dos gastos familiares com saúde, assim como as grandes seguradoras e os planos de saúde.

Ao tempo em que a saúde é concebida num universo individual, as cobranças capitalistas pelo bem-estar nos induzem à percepção de que é nosso organismo que está falhando. Assim, a saúde, que é algo que possui expressão orgânica e individualizada, leva a demandar cuidados que não parecem implicar nosso meio como criador de vulnerabilidades coletivas, que são técnicas e políticas.

o consumo de medicinas, ou mesmo de transportes para acessar os serviços de saúde, ainda que públicos, está baseado numa concepção de que nossas inseguranças sejam enfrentadas individualmente. A própria racionalidade constituinte no objeto parece que tende a obscurecer essa consciência, comprometendo a cidadania como aprendizado social.

As tecnologias médicas que nos cercam em nosso cotidiano nos conquistam não somente por sua presença, mas por suas promessas. 
E, na medida em que uma sociedade de risco procura nos convencer de novas necessidades - introduzindo preocupações cotidianas individualizadas - as oportunidades à qualidade da vida são mediadas por interesses mercantis.

A cientifização da técnica impõe-se cada vez mais a partir do poder dos agentes hegemônicos industriais. A revolução informática para a saúde, dependente dos avanços em microeletrônica, biotecnologia e, entre outros, em física moderna, implica processos de produção também sofisticados.

Entretanto a medicina moderna não dispensa suas ferramentas ou máquinas, seus instrumentos técnicos mais antigos, embora a velocidade das modernizações tenha repercussão sobre as diferentes temporalidades.

A convivência de objetos de diferentes idades é permitida, sobretudo, pela organização hierárquica da oferta de serviços públicos. Já que, podemos dizer, as clínicas e hospitais privados geralmente possuem aparelhos mais sofisticados como estratégia de mercado.

A nova visão permitida ao médico da constituição dos tecidos, das células, através dos equipamentos de ultra-som e tomografias computadorizas, são conquistas históricas. Mas é preciso estar consciente de nosso encantamento para perceber que a maneira de ver nossas doenças tem estado subordinada às formas com as quais as máquinas inteligentes são padronizadas para perceber.

\subsubsection{0 endurecimento tecnológico dos equipamentos médicos}

Sabemos que em nossas sociedades modernas 0 discurso industrial estabelece o crescimento como um objetivo central e, nessa medida, a criação de resposta às necessidades, úteis ou fúteis, se torna uma autojustificação da indústria.

Todavia, onde uma visão ingênua conceberia um equilíbrio dinâmico entre medicina e saúde, a indústria médica não deixa dúvida de que o estado das técnicas disponíveis ao aperfeiçoamento da sociedade é alienável quando mediado por uma lógica de mercado.

Inquestionáveis são as conquistas no processo de busca por eficiência médica, entretanto, o poder para instituir inovações 
de alguns grandes atores hegemônicos denota um movimento sob o domínio dos interesses de mercado e a garantia de seus lucros.

No dizer de Illich (1975:83), "em certas condições de existência, o instrumental da sociedade determina as necessidades que a aplicação dos instrumentos pode também satisfazer". Mas, ainda que o produto industrial seja capaz de tornar a ação mais eficaz, os imperativos de uma eficiência técnica e de mercado estrangulam valores de uso, fazendo esmorecer formas autênticas e insubordinadas de produção e cidadania.

Em sua noção de confiscação institucional ${ }^{18}$ do savoir-faire, Gaudin (1978) explica que o crescimento industrial se dá por uma tendência ao endurecimento tecnológico ${ }^{19}$. A respeito dos equipamentos médicos, observamos esse movimento de produção global pelo número de empresas e países que dominam o mercado de objetos técnicos modernos.

TABELA 2 - Principais importadores e exportadores no comércio internacional de aparelhos e instrumentos para usos médico-hospitalares 2003-2006

\begin{tabular}{c|c}
\hline \hline Exportação & Importação \\
\hline & \\
\hline EUA & EUA \\
\hline Alemanha & Alemanha \\
\hline Holanda & Japão \\
\hline Irlanda & Holanda \\
\hline Japão & Reino Unido \\
\hline Suíça & França \\
\hline França & China \\
\hline China & Canadá \\
\hline Hong Kong & \\
\hline Austrália & \\
\hline Reino Unido & \\
\hline México & Outros \\
\hline Outros & \\
\hline \hline
\end{tabular}

Fonte: Elaboração da Fundação Instituto de Pesquisas Econômicas (FIPE), São Paulo, 2008.

${ }^{18}$ Gaudin (1978: 127) já ensinara que o movimento das técnicas nos dá as modalidades de transmissão do savoir-faire. Dirá o autor que a manipulação dos circuitos financeiros, da informação, dos preços, a introdução da tecnologia, máquinas e engrenagens, revela a aposta dos tempos modernos de despossar o homem moderno de sua técnica, tirando-o do lugar da produção.

19 O endurecimento tecnológico é expresso em três fases: a escolha de um modelo mais rentável, a produção em grande escala para que substitua os modelos correntes (daí a construção de uma ferramenta específica), e a restauração de uma variedade artificial, com lançamentos permanentes de acessórios, embalagens etc. (Gaudin, 1978) 
Vemos que os maiores exportadores e importadores de equipamentos médico-hospitalares e odontológicos são países desenvolvidos, sendo que EUA, Alemanha e Japão têm forte vantagem comparativa na produção de instrumentos e aparelhos de medicina, cirurgia, odontológica e veterinária (FIPE/IPT, 2008).

Segundo o estudo da FIPE e IPT (2008), as dez maiores empresas norte-americanas são Jonhson \& Jonhson, GE Medical System, Baxter Internacional, Tyco Healthcare, Medtronic Inc., Abbot Laboratories, Becton Dikinson, 3M Heathcare, Guidant, Stryker Corp.

Entretanto, para essas empresas, a competição com a Siemens (Alemanha), Corporação Médica Hitachi Toshiba (Japão), Philips Eletronics (Holanda) e Sistemas Medicos Marconi (Itália) envolve principalmente produtos com elevado conteúdo tecnológico.

No endurecimento tecnológico, apesar da multiplicação dos objetos médicos, há uma redução da diversidade da técnica. 0 que se revela quando atentamos a produção hegemônica é a promoção de equipamentos médicos cada vez mais performáticos e especializados, cuja diferenciação é, em grande parte, incremental ou aparente ${ }^{2 \theta}$.

Daí o envolvimento de especialistas médicos ser crucial no desenvolvimento das inovações dos equipamentos médicohospitalares, dirá o estudo de Albuquerque e Cassiolato (2002:142). Como a produção de equipamentos é dependente de uma diversidade de outras áreas do conhecimento e outras indústrias, a produção desses aparelhos exige um saber próprio do médico para "trazer" a tecnologia para a área da saúde.

Essa proximidade do médico à indústria se torna um fator da difusão da inovação, onde o processo entre a invenção, a aceitação para fins industriais e sua afirmação histórica é por isso acelerado. Daí, ainda, poder dizer dos hospitais como parte do sistema de pesquisa dos equipamentos médicos (Albuquerque e Cassiolato, 2002:138).

Empresas como a Siemens, Philips, GE são grandes conglomerados em que a área da saúde é apenas uma dentre as

\footnotetext{
${ }^{20}$ Quando são grande revelações como os tomógrafos, em relação ao raio x, e as ressonâncias, em relação ao ultra-som, são grandes avanços de outras áreas do conhecimento, como a física, a genética, a eletrônica, entre outras.
} 
frentes de produção globalizada. Nesse sentido, seus empenhos em pesquisa e desenvolvimento são dirigidos às plataformas tecnológicas, onde a saúde é apenas um aperfeiçoamento apropriado à área médica.

Entretanto, somos convidados a crer numa diversidade, ou melhor, numa variedade supérflua de necessidades. Daí que algumas opções tecnológicas se tornam assentadas na força dessas empresas incitarem ao consumo. Entretanto, tais modernizações terminam por trazer a inflação de um terciário terapêutico em detrimento da capacidade produtiva de bens à saúde nos diferentes lugares.

Parece que estamos vendo um processo de padronização de modos de fazer, conduzido por poucas e grandes empresas produtoras de equipamentos acrescidos de melhorias que são estéticas e funcionais, não apenas à saúde, mas funcionais no interior do próprio objeto técnico.

Num ensaio sobre técnica e estética, Simondon (2002:258) escreve que ainda que não seja verdade que todo objeto estético tenha um valor técnico, pode-se dizer que todo objeto técnico tem, sob certo aspecto, um teor estético. A indústria médica certamente se vale desse caráter para diferenciar seus produtos.

Poder-se-ia argumentar sobre as necessidades clínicas dos aperfeiçoamentos estéticos, mas certamente não podemos deixar escusos os interesses de mercado da indústria do design e do conforto enquanto abordagem do objeto técnico, e, ainda, o poder do discurso do uso embutido na estrutura funcional dos objetos.

No caso extremo da ressonância magnética, a claustrofobia de muitos pacientes já é hoje razão de competitividade entre as grandes empresas na fabricação de aparelhos onde o indivíduo não precisa mais entrar e ficar todo envolvido pelo aparelho.

Casos mais simples, podemos dizer dos produtos chineses que invadem o mercado nacional com preços inferiores aos nacionais, apresentando agulhas com sofisticado design apropriado para o maior conforto do paciente. Mas, também podemos dizer da diferenciação de produtos para o conforto dos médicos, onde o manejo dos instrumentos deve lhe oferecer um incremento de facilidade, muito próximo a um prazer motor. 
Atualmente os equipamentos médicos são incrementados também e, sobretudo, em seus níveis informacionais, facilitando funções propriamente médicas, mas, antes, exigindo maior sistemismo entre as partes, numa sala, num consultório, num hospital. Esse incremento não é diretamente à saúde, mas é certo que serve a maior produtividade que almeja o prestador do serviço.

Constituído pela estreita associação e interdependência entre a ciência, a técnica, a indústria, a defesa, a administração, um novo sistema de técnicas se faz pela concentração do poder financeiro de agentes hegemônicos, o que favorece esse processo de endurecimento tecnológico.

Suporte de um novo sistema de relações sociais, esse contexto hegemônico da produção médica moderna é responsável por ocultar o savoir-faire, transmitindo-o somente no interior das instituições produtoras. Esse é o modo pelo qual, assevera Gaudin (1978:175), controla-se a técnica, "o verdadeiro lugar das escolhas estratégicas e do exercício do poder".

Se antes a diferenciação dos objetos esteve assentada em consequência do uso cada vez mais especializado, hoje é válido acrescentar nesse processo as estratégias de mercado das empresas hegemônicas. Nesse sentido, a confiscação da técnica pelo endurecimento tecnológico parece algo como uma confiscação da saúde.

Nessa direção, Sennet (2006:128) dirá que o que torna lucrativa a diferenciação de produtos no contexto moderno se sustenta no que chamou de paixão consumptiva. Ao gosto individual, a paixão consumptiva se baseia numa identificação do comprador com o excesso de capacidade contido no objeto. Na indústria eletrônica é comum que equipamentos sejam adquiridos sem que sejam utilizados em todas suas virtualidades ${ }^{21}$.

Ainda que médicos ou pacientes, hospitais ou governos não sejam simples consumidores, tampouco serem os objetos médicos quaisquer objetos, todos estão sujeitos aos mecanismos que encorajam consumos ostentatórios, pois se trata de um processo mais abrangente nas sociedades.

\footnotetext{
${ }^{21}$ Sennet (2006:139) assevera que a renúncia ao objeto hoje não é vivenciada pela perda, mas se coaduna com o processo de busca de novos estímulos. O mercado apela para que consumidores estejam envolvidos num ambiente imagístico forte na expectativa, mais do que no uso do objeto, e associa essa paixão consumptiva à intemperança e o desperdício.
} 
No caso da saúde, a questão é que a dinâmica dos territórios responde a essas opções influenciadas por instrumentos de trabalho submetidos a preferências custosas que, além de criarem fragmentação, nem sempre correspondem às exigências das populações.

Ainda e, sobretudo, essas predileções por objetos mais e mais sofisticados nos fazem encantados por objetos os quais não fabricamos. Digamos que esses consumos desmedidos têm participação num movimento de obsolescência da própria capacidade do país produzir saúde.

A novidade demanda a criação de habilidades técnicas e, por esse lado, revela um modo de influência da indústria na definição das profissões ligadas à área médica. A destreza exigida na prática médica mobiliza um mercado permanente de cursos técnicos e atualização profissional, além de tecnológica.

Evidência disso é a proximidade com que a indústria médica está para com seu mercado. Por meio da visita de oferta das novidades médicas, médicos, hospitais, clínicas são focos das estratégias de venda das indústrias hegemônicas, bem como não hegemônicas.

Mas quando o Estado e a sociedade já se tornaram convencidos de necessidades sempre renovadas, tais práticas são ignoradas. 0 médico aparece apenas como um cliente ${ }^{22}$ da indústria, ou seja, o nexo entre o profissional de saúde e a indústria aparece apenas como ambiente mercadológico.

0 processo de endurecimento tecnológico é identificado, portanto, por um crescimento "desinovador", marcado pela

\footnotetext{
${ }^{22}$ Quase metade dos médicos paulistas que recebem visitas de propagandistas de laboratórios prescreve medicamentos sugeridos pelos fabricantes, é o que diz a pesquisa do Conselho Regional de Medicina do Estado de São Paulo (Cremesp). Tal pesquisa avaliou o comportamento médico perante a indústria, com 600 médicos de várias especialidades, dentro de um universo de 100 mil profissionais que atuam no estado de São Paulo. Na área de equipamentos médico-hospitalares, a eficácia da visita é de $71 \%$, os profissionais de saúde acatam a recomendação da indústria. Do total, $80 \%$ deles recebem visitas dos propagandistas, em média 8 por mês; $93 \%$ diz ter recebido produtos, benefícios ou pagamentos da indústria em valores até 500 reais nos últimos 12 meses; e 37\% declaram que já receberam presentes de maior valor desde cursos à viagens para congressos internacionais. Mas a sedução da indústria começa com os estudantes de medicina, quando a mesma pesquisa mostra que $74 \%$ dos médicos declararam ter presenciado ou recebido benefícios durante os seis anos de curso, com brindes, patrocínios à eventos científicos e esportivos. Fonte: Folha de São Paulo, 31 de maio de 2010.
} 
multiplicação de um mesmo objeto e, sobretudo, pela redução da competência relativa da produção noutros lugares do mundo.

Quando Santos (2003:188) mostra que os mais recentes avanços tecnológicos equipam as economias centrais de objetos cuja estrutura técnica abriga intencionalidades, ensina que a partir do pós-guerra, as coisas adquiriram um tipo de potencialidade que nunca haviam possuído anteriormente.

A saúde mediada por objetos endurecidos e eficazes se mostra parte de um subsistema hegemônico e, tanto a produção quanto seu consumo, tendem a se tornar hegemonizados pelo poder de ação que possuem alguns agentes.

Por terem papel sobre a cientifização dos objetos, tais agentes exercem influência determinante na forma como o trabalho se divide. As técnicas, como ensina Silveira (2000:213), não podem ser interpretadas apenas como materialidade, pois são também formas de organização, imperativos de regulação.

Através das formas, a estrutura socioeconômica de um país pode ser facilmente atacada, ensina Santos (2003:190) e, em conseqüência, "o mecanismo do planejamento tornou-se mais sutil”. Daí por diante, o fato notável é que foi possível dirigir a ação exclusivamente às formas e não mais necessariamente a formas e estrutura juntas.

As normalizações técnicas incorporadas aos equipamentos médicos - que, por um lado, são efeito dos padrões empreendidos pelos avanços da medicina, por outro, são também mobilizadas pelas estratégias comerciais de grandes agentes econômicos, sendo que, em certa medida, esses agentes assumem esse duplo papel - revelam-se como um mecanismo estrutural, cujas variáveis se tornam determinantes no modo como a saúde se realiza no país.

Nesse sentido, a tecnificação da medicina por parte dos agentes hegemônicos acirra um meio em que será preciso provar a eficácia dos objetos a partir dos parâmetros engendrados pelos próprios fabricantes, os quais dominam grande parte da pesquisa e desenvolvimento e suas normas de uso.

"Quando tanto se fala em flexibilização e flexibilidade do modelo de acumulação, defrontamo-nos com um verdadeiro endurecimento organizacional, devido a indispensabilidade das normas de ação, tanto mais rígidas quanto mais se pretende 
alcançar a produtividade e a sacrosanta competitividade”. (Santos, 1996:144)

A existência de segredos agregados a esses objetos, assim como as reservas normativas por meio de patentes, são, bem verdade, exemplos de um processo amplo de endurecimento organizacional determinante à regulação do uso dos novos objetos.

A subtração da aptidão de outros agentes produzirem e, com efeito, promoverem saúde, depende, nesse sentido, da capacidade desses conglomerados fabricarem equipamentos médicos, considerando que, com isso, organizam em seu favor a divisão do trabalho em escala global.

Efeito próprio dos países do Terceiro Mundo em relação aos processos de modernização em saúde, esse “esvaziamento" relativo da produção de equipamentos médicos nacional é entendido a partir do controle e manipulação, pelas empresas hegemônicas, das variáveis-força do período, a técnica, a ciência, a informação, a finança.

"Antes os sistemas técnicos eram apenas locais ou regionais. $\mathrm{Na}$ aurora da história havia tantos sistemas técnicos quanto eram os lugares. Quando apresentavam traços semelhantes não havia contemporaneidade entre eles, muito menos interdependência funcional. A história humana é igualmente a história da diminuição progressiva do número de sistemas técnicos autônomos (relativamente) sobre a face da terra. O movimento de unificação, acelerado pelo capitalismo, hoje alcança o seu ápice, com a predominância em toda parte de um único sistema técnico, base material da globalização.” (Santos, 1999:8)

Vemos que a existência sistêmica da técnica, hoje à escala do planeta, mostra que os cuidados à saúde das populações se defrontam com o poder de ação dessa produção heteronômica.

A existência no país de um arsenal de pequenos fabricantes de equipamentos médico-hospitalares de menor complexidade tecnológica é reveladora dos processos historicamente intrínsecos em respostas às contradições particulares de uma determinada sociedade em relação ao desenvolvimento desigual.

Dedicaremos esse debate aos capítulos a frente, mas, de modo geral, podemos dizer que as empresas mais antigas do país estão na metrópole de São Paulo. São também as maiores empresas do 
ramo, não apenas pelo pessoal ocupado (com mais de 500 funcionários cada), mas pelo maior rendimento, e representam apenas $8,5 \%$ do total das empresas nacionais.

Apesar de virem intensificando a inserção no mercado internacional, num contexto em que o Brasil representa apenas $1 \%$ dos 310 bilhões de dólares da produção mundial, essas grandes empresas nacionais possuem tradicionalmente esforços tecnológicos em produtos específicos para garantir seu poder no mercado nacional.

No entanto, 34\% são médias (até 499 funcionários) e quase 58\% são micro e pequenas empresas (até 99 funcionários), e responsáveis pela geração de $91 \%$ do emprego entre os fabricantes de equipamentos médicos no país. São Paulo, nesse sentido, é o principal estado não apenas produtor, mas também onde se abriga $57 \%$ do emprego da produção nacional.

Ainda, podemos mencionar esse estudo da FIPE (2008:22) que revelou haver, entre 1998 e 2004, um aumento da participação do emprego das pequenas empresas em 3,3\% em contrapartida ao montante aproximadamente igual à redução da participação do emprego nas médias empresas no mesmo período.

Nesse sentido, a produção de equipamentos médicos no país compreende um perfil em que são as grandes empresas nacionais as mais antigas. Isto quer dizer que as grandes empresas no país são aquelas firmas que, num contexto de permanente dinamismo conseguiram desempenhar certa capacidade de capital, tecnologia e organização.

Entretanto, a enorme maioria das firmas nacionais são pequenas e médias empresas, sendo que são também aquelas com maior proporção de responsabilidade no abastecimento do mercado interno, dado que menos de $10 \%$ da produção nacional é exportado e, pelas maiores empresas.

Daí que, para compreender as diferenças no impacto do modo de produção técnico científico sobre as diversas regiões e lugares, devemos atentar para o papel do Estado, da sociedade civil e da própria configuração social na mediação dos vetores externos.

Os modos de cuidar da saúde na atualidade não prescindem da observação do fenômeno indissolúvel entre o modo de produção e o espaço geográfico. Todavia, como ensina Santos (1977), a 
história espacial é seletiva e o lugar torna-se a cada momento dotado de uma significação particular.

Hoje, momento em que os objetos passam a ser, sobretudo, informação (Santos, 1992:53) a intencionalidade das ações hegemônicas compreende uma racionalidade tanto na concepção do objeto, quanto na sua localização. Ações com base científica constituem fins definidos e estão em conformidade também com os meios, isto é, com os próprios objetos.

o trabalho se torna mais e mais científico e, com efeito, o território se informatiza ainda mais depressa que a economia e a sociedade. Explica Santos (1988:59) que, sem dúvida, tudo se informatiza, "mas o território se informatiza ainda mais, na medida em que o trato do território supõe o uso da informação, que está presente também nos objetos."

Podemos observar os subsistemas técnicos hegemônicos e a natureza geográfica da saúde hoje a partir da concentração das medicinas modernas. 0 meio geográfico tornado mais denso e complexo responde como se dão a produção e o consumo da saúde.

Se por um lado a constituição técnica e normativa dos lugares mostra-se como dificuldade de produzir os bens ou acompanhar o imperativo dos avanços para a saúde, por outro, vemos o crescimento de um mercado para novos serviços ligados aos equipamentos médico-hospitalares.

Esses aparelhos, sem os quais a medicina se torna inoperante, mostram, portanto, geografias reveladoras. A concentração de equipamentos e hospitais sofisticados, a concentração da produção nacional de aparelhos mais simples tecnologicamente, a multiplicação de atividades correlatas, são expressões de um mesmo fenômeno, a globalização incompleta.

A capacidade de ações tornarem-se hegemônicas a partir das atuais variáveis determinantes, que são a informação e as finanças, define o novo patamar do processo de internacionalização e o poder de alguns agentes para hierarquizar outras divisões do trabalho.

\subsection{3.i. A diversidade irredutível}

Desde que a ciência moderna passa a preceder a técnica, a inovação industrial acredita que apenas a idéia científica 
conta, de modo que a pesquisa se torna única causa legítima de inovação. Daí que será preciso examinar alguns parâmetros do conceito de inovação para permitir nossa observação sobre a economia urbana ligada aos equipamentos médicos.

No entanto, a própria difusão de objetos que, como vimos, ocorre facilmente em escala global, obedece à lei da imitação que nos dizia G. Tarde (1921). A dinâmica da imitação é própria de um modo de existência popular e difuso da técnica, portanto, pertence a um âmbito social estendido, que não coincide com as formas instituídas da pesquisa científica.

Gaudin (1978:15) de outro modo dirá que é a maneira como a idéia se realiza, se difunde, se transmite que transforma a realidade. Ao contrário do que dizem os representantes institucionais, a pesquisa não será causa única da inovação, se as técnicas estão compreendidas por um processo incessante de interação social, onde iniciativas heterogêneas e improváveis também encontram seus contextos de invenção no movimento da sociedade.

Isso nos leva a verificar que o trabalho mais produtivo economicamente provoca um discurso e sua aceitação na vida social, na medida em que um controle da criação de novidades incessantes é exercido pela criação cotidiana de um homem ignorante.

M. Chauí (1984:11) nos inspira a conceber a natureza ideológica da incorporação de tecnologias médicas ao cuidado à saúde ao escrever que "a condição para o prestígio e para a eficácia do discurso da competência como discurso do conhecimento depende da afirmação tácita e da aceitação tácita da incompetência dos homens enquanto sujeitos sociais e políticos”.

Ao refletir sobre a criação da necessidade do discurso, Santos (1992) escreveu:

"O aparelho de barbear traz a indicação de como utilizá-lo e o instrumento mais complicado tão pouco se utiliza sem esse discurso, criando na sociedade os especialistas dos discursos especiais, ao mesmo tempo em que se debilita a criação do homem capaz de fazer o discurso do todo, isto é, de entender a história e de propor uma nova história." (Santos, 1992:54) 
Graças à posição que ocupa e disso se possa desviar o interesse social para interrogar o presente e a história, o conhecimento passa a servir de justificação a uma suposta neutralidade racional. Efeito dessa recusa pelo saber que habita a experiência, o discurso se vale da capa da cientificidade, onde encontra a legitimidade de certas formas de dominação.

As técnicas populares defrontam as técnicas elitistas num modo de existência que, como ensina Gaudin (1978:160), não existe em estado puro, mas cujo movimento oscila entre um modo concentrado, da especialização, e um modo disperso, da bricolagem e auto-produção.

0 enfoque de que há um movimento do mundo, dado por uma ordem unitária que então reúne em uma mesma lógica atores e objetos tão diversos, implica o pressuposto de uma visão ontológica. Como nos ensina Santos (1996:96) a produção do real não passa de um real abstrato, cuja realização concreta da historicidade somente pode dar-se no espaço.

A variedade das buscas por meios de sobrevivência, alternativas de realização do trabalho em diferentes contextos, e a criatividade dos agentes são expressão de um conteúdo existencial $^{23}$ da constituição do espaço geográfico.

0 território usado se constitui por uma diversidade de agentes, apesar de suas diferenças. Na sociedade do capitalismo, escreve Zaoual (2006:62), “[...] tudo está interligado. Contrariamente às crenças científicas dos economistas, a sociedade do capital é irreduzível a um simples sistema técnico ou mesmo a um sistema econômico".

Como ensina Santos (1996b), o espaço geográfico é o espaço de todos os homens, independente de suas qualidades, de todas as empresas, independente de sua força, de todas as instituições, independente de seu poder normativo.

Mesmo sem adentrar, por ora, o universo próprio da densificação e complexificação dos circuitos da economia urbana, ainda detidos nessa caracterização da natureza atual dos objetos e das ações para a saúde, podemos observar as repercussões criativas da evolução das técnicas, no âmbito da produção dos equipamentos médicos. 
Quando o savoir-faire se torna socialização pelo uso, uma visão dicotômica da hegemonia se torna ainda mais destituída de sentido. A produção de bens e serviços vinculados aos equipamentos médicos possui diferentes níveis de capital, tecnologia e organização.

Como manifestação resultante da mesma causa modernizadora, ensina Santos (1978), diferentes divisões territoriais do trabalho permitem novos nexos que multiplicam as atividades possíveis em diferentes contextos. Nesse sentido, a coexistência é valorizada por sua diferença e o movimento das técnicas aparece como resposta à existência em sua diversidade.

Micro e pequenas empresas representativas da produção nacional revelam estratégias particulares na ocupação de interstícios da economia urbana, a partir de uma variedade de objetos médicos que são de menor complexidade tecnológica.

Vale lembrar que embora um hospital de alta complexidade seja o ambiente adequado aos equipamentos mais sofisticados, ainda constitui sua demanda afastadores de língua, agulhas, soro, macas, chapas e filmes, cadeira de rodas, entre muitos outros objetos.

Também, como já apontamos, a expansão de um terciário ligado aos diagnósticos e terapias modernas multiplica empregos e diversifica os serviços de saúde, tornando mais densa a economia urbana ligada aos equipamentos médico-hospitalares.

Os avanços dos conhecimentos médicos praticados pela indústria induzem à transformação das qualificações profissionais, das reparações dos aparelhos, das consultorias para melhoria da produção e da gestão dos fabricantes nacionais, das consultorias para a produtividade de hospitais, o que evidencia o poder de influência dos interesses hegemônicos.

Daí porque Santos (1996:173) nos alertara para a intencionalidade dos objetos técnicos não apenas inscritas na concepção da sua estrutura interna, isto é, no papel que desempenham, mas na sua localização, onde tal objetividade responde a uma funcionalidade cujo interesse é distante.

A miopia global do pensamento global, escreve Zaoual (2006:63), ofusca a percepção de que riqueza e pobreza são criadas ao mesmo tempo, pois entre a descoberta científica e a 
adoção da inovação o caminho estará, por princípio, definido pelo que corresponde ao mercado, pelo que rende lucro, pelo que reforça o controle do sistema sobre outros homens.

\subsection{Consumo e cidadania}

Ao passo em que a sociedade enfrenta tantos avanços e contradições inerentes, o medo líquido, o qual Bauman ${ }^{24}$ (2008) nos chamou atenção, faz despontar no cotidiano as esferas dos medos. A ciência médica, como agente importante no aumento das "advertências globais", pressupõe nossas vulnerabilidades e, quando tomada pelas empresas mundiais, torna-se uma complexa indústria do bem-estar e da esperança.

Sendo anunciados diariamente novos perigos, as demandas por seguros se tornam estratagemas sagazes numa economia do consumo. Dependente da produção de consumidores, a esfera da busca contínua de afastar a iminência dos perigos se expressa por uma indústria de seguros, que estimula a pensar nos obstáculos como riscos ${ }^{25}$, cujos perigos são calculáveis.

Soluções que nascem antes de problemas, somos atraídos pela possibilidade de viver a crédito. Com as facilidades oferecidas por uma variedade de agentes financeiros, satisfazemos nossas necessidades de cuidados de toda ordem, antes que chegue o inesperado, o arriscado, o detestável, o inadministrável.

Diante de nossas necessidades de cuidados, os seguros de saúde entram nos custos de vida até mesmo das classes empobrecidas do país. As adesões, aliás, são parte da estratégia das empresas operadoras dos planos de saúde que ampliam ${ }^{26}$ o

24 O medo líquido discutido por Zigmunt. Bauman (2006) dirá que a modernidade contemporânea desmoronou nossas utopias de controle e expôs nossos medos. Daí os estratagemas, os quais o autor chamou para designar a inventividade humana que historicamente busca afastar, mesmo que temporariamente, a ameaça dos perigos e retardar a frustração do homem quando se reconhece temporário e imperfeito. Da mesma forma, os estratagemas propõem a garantia de afastar o medo e burlar o tempo, e não retardar a satisfação de meios seguros e confortáveis para viver.

${ }^{25}$ No contexto da sociedade de risco, proposta por Ulrich Beck (1992), a consciência do risco repousa não no presente, mas no futuro.

26 De acordo com a Associação Brasileira de Medicina de Grupo, em declaração ao Jornal da Tarde em 02 de junho de 2010, os novos compradores dos planos de saúde são pessoas que acederam a classe $\mathrm{C}$, sendo esses o público potencial. Entretanto, a racionalidade a qual essa estratégia reage parece estar ligada a um tipo de inflação médica criada pelos leitos privados equipados e vazios, pelo grande número de médicos, a cada ano, credenciados, a qual as 
acesso aos serviços de saúde sem consonância com a disponibilidade proporcional com os equipamentos disponíveis.

Nesse caminho das demandas, as crescentes modernizações hospitalares são justificadas, sendo o hospital reconhecido, espontânea ou organizacionalmente, como centro da possibilidade de responder às nossas exigências vitais.

0 nível de automatismo que se deseja dos equipamentos médicos, ou do próprio hospital, propõe crescentes modernizações, cujo critério se encontra na própria tecnicidade das soluções. A sociedade convencida desses valores técnicos ${ }^{27}$, ou seja, da racionalidade instrumental e eficácia dos meios, deixa que a técnica, ela própria, opere as escolhas a utilizar.

A difusão das inovações que, por sua natureza, é seletiva, encontra a hierarquia funcional do sistema universal de saúde como base territorial sobre a qual as modernizações vêm aprofundar desigualdades em relação ao acesso aos serviços de saúde.

Cada instituição hospitalar é um organismo complexo com maior ou menor autonomia para demandar seus próprios aparelhos. De modo que o sistema de saúde como um todo, abarcando serviços públicos, filantrópicos e privados, administrados de diferentes formas, encontra dificuldades de coordenar o arsenal de objetos em função das necessidades da população.

o hospital, mais ou menos capaz de desempenhos específicos, sendo um subsistema técnico em si mesmo, exerce um papel subjacente na dinâmica socioespacial mais ampla. Nesse sentido, assumimos que o hospital representa um peso no processo sistêmico de medicalização da saúde, atraindo para si um poder de definição das demandas econômicas e cidadãs.

operadoras encontram nessa classe $\mathrm{C}$ um modo de diluir os custos e diminuir o impacto da inflação médica.

27 "A disponibilidade de um arsenal tecnológico crescentemente sofisticado e a inclinação médica à sua utilização têm colaborado para um substancial aumento nos custos da assistência à saúde sem necessariamente serem acompanhadas por um aumento da equidade e eficácia do sistema de saúde. As novas tecnologias têm sido incorporadas sem uma avaliação sistemática de sua eficácia e segurança, estabelecendo um sistema sem capacidade de regulação e afetando, por outro lado, a economia nacional - tais equipamentos são em sua maioria importados, gerando um ônus na balança comercial do país e em detrimento dos produtos nacionais. A compra de equipamentos de alta complexidade não é necessariamente a melhor opção. São recorrentes as situações em que esses aparelhos se encontram em hospitais que não possuem pessoal capacitado para operá-los e/ou não têm condições sequer de arcar com seus custos de manutenção.” BNDES, Setorial, 2004. 
À frente na incorporação das inovações, o hospital se torna importante no aprimoramento de novas tecnologias, assim como é um pivô do sistema de assistência médica nacional e, nesse sentido, atesta a força legitimadora do discurso científico.

\subsubsection{0 discurso competente da ciência}

o discurso competente é o discurso instituído, escreve Chauí:

"O discurso competente confunde-se, pois, com a linguagem institucionalmente permitida ou autorizada, isto é, com um discurso no qual os interlocutores já foram previamente reconhecidos como tendo o direito de falar e ouvir, no qual os lugares e as circunstâncias já foram predeterminados para que seja permitido falar e ouvir e, enfim, no qual o conteúdo e a forma já foram autorizados segundo os cânones da esfera de sua própria competência.” (Chauí, 1984:7)

A cientificização da técnica, processo marcado desde o final do século XIX, não mostra mais um simples poder de disposição técnica. Quando se torna ela mesma mola propulsora do progresso técnico, o interesse incessante pela sofisticação marca uma mudança histórica, onde a técnica e a ciência transformaram-se em forças produtivas, elevando a novos patamares a racionalização.

A introdução continuada de inovações tecnológicas para os cuidados à saúde expressa a constituição material e ideológica com que a tecnociência e a informação fundam as práticas da saúde numa economia globalizada. A investigação industrial em grande estilo, a organização atual da assistência médica, estão amparados pelo papel que assume o discurso instituído da ciência.

Como veremos, a política de saúde no país, seja em seu âmbito produtivo ou na dimensão da assistência médica, demonstra de que maneira o discurso competente da saúde, por meio da tecnociência como força produtiva, se integra na estrutura institucional do Estado e da sociedade como um todo.

Daí acompanharmos Chauí (1984) quando diz que podemos observar o discurso competente enquanto discurso do conhecimento a partir da burocratização da sociedade contemporânea e a idéia 
de organização na base desse fenômeno. 0 sistema de saúde do país, veremos, está prenhe dessas formas e nexos modernos.

Habermas, em seus estudos de 1968 (2006:81), irá dizer que a nova ideologia se distingue das antigas pelo fato de separar os critérios de justificação da organização da convivência, portanto, das regulações normativas da interação em geral. Despolitizando tais critérios, vincula-os às funções de um suposto sistema de ação racional dirigida a fins específicos.

A produção de uma consciência tecnocrática ${ }^{28}$ é "menos ideológica” que as precedentes, por não ser um poder opaco que sugere falsamente a realização do interesse. É, pois, uma ideologia de fundo, dirá Habermas (2006:80).

Proferida do alto, inscrita no mundo, a ciência institucionalizada é declarada pelos experts. Inclinada a fundar-se na pura racionalidade de fatos racionais, a ciência é convertida em discurso anônimo e impessoal e, como assevera Habermas (2006), arrisca-se a não passar de discurso à existência real da dominação.

A concepção normativa do desenvolvimento histórico erigiu as bases para que certa ideologia se fizesse dominante e eficaz, pela racionalização das relações vitais. Quando a modernização compreendida pela perspectiva única do acúmulo de riquezas e o critério é a própria racionalidade dos meios de ação, outras formas de experiência no universo do trabalho são desprestigiadas.

A ciência enquanto variável mobilizadora na organização das atividades e cuidados à saúde revela-se como uma espécie de hegemonia do saber, onde o sistema tenta planejar a descoberta com base em seus próprios critérios de verdade.

Zaoual (2006:162), em sua crítica às certezas absolutas nas quais se assentam as teorias econômicas, escreve que o problema não é admitir que essa visão de mundo possa oferecer algumas receitas na gestão de negócios dos homens, mas, pelo contrário,

${ }^{28}$ Para Habermas (2006), essa consciência tecnocrática hoje dominante, é vítrea, fazendo da ciência um feitiço mais irresistível e de maior alcance do que as ideologias de tipo antigo, pois, na medida em que dissimula as questões, afeta, sobretudo, o interesse emancipador do gênero humano. 
é a arrogância quanto à sua capacidade de dirigir sistemas tão complexos como são as sociedades humanas.

Gaudin (1978) é quem nos inspira ao questionamento sobre o poder de instituir das instituições, não estritamente no sentido jurídico, mas em seu sentido amplo de organização. Voltaremos nessa observação mais a frente.

Haverá, nesse sentido, uma ignorância ideológica a partir da diminuição da capacidade de reação dos demais agentes, pois se impõe ao ser-lhes negado o saber enquanto fruto do trabalho, isto é, por não ser conhecimento em sua forma instituída.

Reduzido o espaço do pluralismo no campo das ciências e, de maneira geral, no do pensamento humano, como alerta Zaoual (2006:64), dinâmicas urbanas são aproveitadas pela indústria hegemônica, ampliando mercados, cujo viés contemporâneo mais parece com uma indústria da doença.

Daí que a consciência tecnocrática não pode basear-se numa repressão coletiva do mesmo modo que as velhas ideologias, assevera Habermas (2006:81), pois a lealdade das massas só pode ser obtida por meio de compensações destinadas à satisfação das necessidades privatizadas.

0 "consumidor-mais-que-perfeito ${ }^{29 "}$ (Santos, 1987, 1998) de hoje busca na diferença de objetos o estímulo que os personaliza, mas cujos procedimentos são cada vez mais homogeneizados. Ao escrever sobre a cultura do novo capitalismo, Sennet (2006) aponta que a questão do consumo nos leva ao cerne da nova economia.

Ao passo em que o reconhecimento de um bom profissional de saúde é denotado pela capacidade de adquirir equipamentos de última geração, pacientes, o constatamos pela segurança assimilada na solicitação de exames e prescrições médicas.

A saúde, nesse sentido, é traduzida no imaginário popular como o resultado de técnicas bem aplicadas. A percepção social do que é e como se pode alcançar saúde passa a ser um poder

\footnotetext{
${ }^{29} \mathrm{O}$ modelo de desenvolvimento neoliberal empenhado pelo país a partir dos anos 1970, e o progresso econômico dele resultante, foi responsável, como nos explica Santos (1987), pela atrofia da cidadania, que se deu em detrimento da formação de um consumidor-mais-queperfeito.
} 
banal da sociedade que, através do consumo, decide o que é publicamente valioso.

Com efeito, essa psicoesfera (Santos, 1996) assim alimentada ${ }^{30}$, institui e legitima modos de fazer que terminam por restringir que outras formas de trabalho, menos subordinadas, venham suprir de outro modo suas necessidades de saúde.

\subsubsection{A saúde como consumo e vínculo cidadão}

A maneira neoliberal de nos fazer ser reconhecido em nossos direitos, ao mesmo tempo em que cresce a descrença das instituições públicas, nos envolve no sentimento de que pertencemos quando ocupamo-nos de consumir.

Firmas hegemônicas, bancos e tantas outras instituições nãogovernamentais assumem influentes posições que transformam as práticas que dão sentido de pertencimento a uma nação, enquanto a vida social se torna regulada em função de interesses privatistas.

Nesse sentido, o subsistema técnico médico que vem sustentar a garantia do direito à saúde hoje revela, por parte dos poderes públicos e privados, um modelo de introdução de inovações que contribui para associar a idéia dos cuidados à saúde da população à velha noção de ausência de doença.

A assistência médica se torna necessidade premente, gerando uma demanda sempre crescente para os serviços hospitalares e o consumo de serviços médicos. De modo geral, podemos dizer que esse fenômeno torna mais complexo o debate contemporâneo sobre os modos pelos quais a saúde é exercida como consumo, e este como direito à cidadania.

As influências liberais que, num primeiro momento, concebe os homens cidadãos e, num segundo, trata-os como consumidores compreende o desenvolvimento histórico das democracias. No

30 G. Canguilhem (1989, 2005:24) escreve que "nas sociedades contemporâneas em que a medicina se empenhou para se tornar uma ciência das doenças, a vulgarização do saber, por um lado, e as instituições de saúde pública, por outro, fazem com que, na maioria dos casos, o viver a doença para o doente seja também o falar dela ou ouvir falar dela segundo clichês ou estereótipos, isto é, valorizar implicitamente as recaídas de um saber cujos progressos são, em parte, devidos ao fato de o doente ter sido posto entre par6enteses enquanto eleito da diligência médica”. 
Brasil, a formação dos direitos essenciais mostra que a cidadania não se completou enquanto processo cívico.

A formação da classe média com suas demandas de conforto e bem-estar, e seu alargamento a partir dos anos 1990, vem transformando a herança moral que sustenta nossos direitos sociais.

A elaboração brasileira do não-cidadão pretende que estejamos convencidos de que o acesso à saúde seja assegurado pela tecnificação dos serviços públicos de saúde e pela desmercantilização do acesso, tornado gratuito pelo sistema universal.

Sabemos que não há gratuidade nem por parte do sistema público, financiado com dinheiro do contribuinte, nem por parte do cidadão que, de acordo com a distribuição hierarquizada dos serviços, percorrerá maiores distâncias, quanto mais complexo tratamento precisar.

Nesse sentido, ser cidadão não tem a ver apenas com os direitos reconhecidos pelos aparelhos estatais para os que nasceram em um território, mas com as práticas sociais que organizam a satisfação das necessidades coletivas e dão sentido à vida pública e individual.

Canclini (2008:35) nos orienta nessa direção sobre as transformações nos vínculos entre consumo e cidadania, pretendendo desconstruir as concepções que julgam os comportamentos dos consumidores como irracionais, isto é, que veem os cidadãos atuando em função da racionalidade dos princípios ideológicos.

$\mathrm{Na}$ tabela seguinte vemos as despesas com saúde no rendimento familiar, por regiões metropolitanas. 
TABELA 3 - Despesa com saúde no rendimento familiar, por Regiões Metropolitanas - 1987 e 1996

\begin{tabular}{|c|r|r|}
\hline \hline Região Metropolitana & $\begin{array}{l}\text { \% do } \\
\text { rendimento } \\
\text { familiar - 1987 }\end{array}$ & $\begin{array}{l}\text { \% do } \\
\text { rendimento } \\
\text { familiar - 1996 }\end{array}$ \\
\hline RM de Belém & 5,6 & 6,1 \\
\hline RM de Fortaleza & 5,2 & 4,8 \\
\hline RM de Recife & 4,9 & 7,4 \\
\hline RM de Salvador & 4,5 & 6,3 \\
\hline RM de Belo Horizonte & 6,2 & 7 \\
\hline RM do Rio de Janeiro & 4,7 & 5,6 \\
\hline RM de São Paulo & 5,7 & 6,2 \\
\hline RM de Curitiba & 6,7 & 6,9 \\
\hline RM de Porto Alegre & 6,4 & 5,4 \\
\hline Total & 5,5 & 6,1 \\
\hline \hline
\end{tabular}

Fonte: IBGE/POF, 1987 e 1997

Nesse debate em que as mudanças na maneira de consumir alteram as possibilidades e as formas de exercer a cidadania, Canclini (2008) nos lembra que a capacidade de apropriação de bens de consumo sempre esteve associada à noção de cidadania, mas as diferenças estavam compensadas pela igualdade em direitos abstratos.

Hoje, a modernidade líquida (Bauman, 2001) desmascarou as contradições das legitimidades constituídas. Nosso atual modelo de sociedade, prevendo que muitas funções do Estado sejam assumidas, direta ou indiretamente, por corporações privadas, refaz os vínculos reais entre Estado e sociedade, reconfigurando as formas de participação e pertencimento através da ordem do consumo.

Não significa prognosticar a dissolução da cidadania no consumo, alerta Canclini (2008). Daí a passagem do cidadão como representante da opinião pública ao cidadão interessado em desfrutar de certa qualidade de vida revela a saúde não apenas como direito, mas também como consumo.

Inscrito na letra das leis e assegurado por dispositivos institucionais, o direito à saúde e seus modos de fazer valer à condição cidadã caminham, pois, com a transformação social. Mutante como aprendizado social e como condição de ser reclamada, a garantia da cidadania não se fará sem que dependa também da noção de individualidade. 
É factível observar que, nas últimas décadas, o mercado desacreditou a atividade política ao exibir sua eficácia para organizar as sociedades, conduzindo a descrença em instituições políticas e alimentando a concepção de que os interesses cidadãos devem receber respostas por meio dos consumos privados.

A saúde como direito e como bem coletivo a ser consumido não foge a essa processo. A realidade do cidadão é partilhada num cotidiano que, pela glorificação do consumo em que está enredada, não se ocupa de fazer florescer as individualidades.

Ao diminuir outras sensibilidades, a formação de um cidadãoconsumidor se confunde com individualismo e subverte o exercício eficaz da cidadania por meio de respostas setoriais e estímulos conformados em satisfações limitadas. A saúde hegemonicamente produzida e consumida nos convida a correr esse risco. 


\section{CAPÍTULO 2. O TERRITÓRIO ATIVO NA CONSTITUIÇÃO DAS EXISTÊNCIAS}

\subsection{A espessura da divisão do trabalho na região concentrada}

o meio geográfico do atual período é produzido e produz dinamismos de um mercado que se torna global. 0 nexo informacional assegura a presença planetária do novo sistema técnico, que empenha as condições de implantação de uma nova forma de organização do trabalho.

As técnicas informacionais permitem a repartição do trabalho em muitos lugares, ampliando a área de abrangência dos sistemas de objetos e ações. Ainda assim, vemos que a economia hegemônica não prescinde da existência de áreas contínuas, dotadas de infraestruturas coletivas unificadas quanto ao seu uso produtivo (Santos e Silveira, 2001:140).

Constituindo um meio técnico científico e informacional concentrado nas regiões onde já há uma densidade da divisão territorial do trabalho, a economia hegemônica tende à especialização cada vez maior das áreas produtivas, expressando um movimento de concentração implícita à sua lógica seletiva de valorização dos lugares.

Os lugares são tomados por suas condições de aproveitamento advindas das possibilidades de aplicação da ciência e da técnica à produção e à circulação. E a economia, assim acelerada pela necessidade de intercâmbio, vale-se daquelas áreas em que o trabalho é já concentrado, sendo essa a maneira pela qual o capital se torna unificado.

A presença de grandes conglomerados torna essa concentração da economia ainda maior em algumas cidades, pois a quantidade de capitais fixos envolvidos na produção moderna, pela demanda de assessoramento industrial, financeiro, jurídico não permite que tal interesse se realize em qualquer parte.

De modo geral, a concentração seletiva e cumulativa da produção moderna mostra de que modo os fatores da produção técnico-científica, informacional e financeira condicionam um sistema territorial comandado por esse subsistema hegemônico. E não é de se estranhar que as empresas ligadas ao sistema produtivo hegemônico de equipamentos médico-hospitalares estejam instalas na Região Concentrada (Santos e Ribeiro, 1979), pois a 
economia moderna vem exigir insumos científicos que, no país, são também concentrados.

As grandes empresas hegemônicas mundiais recentemente têm se instalado no país não apenas aproveitando o crescimento do mercado brasileiro de equipamentos modernos, sobretudo de diagnóstico por imagem, como também vêm aproveitar suas plantas industriais no país para fabricar e vender para países latinoamericanos e, a longo prazo, para China, India e Europa Ocidental.

Ainda mais, tomam proveito da capacidade produtiva nacional quando adquirem importantes empresas nacionais e, a longo prazo "treinam" outras a servirem a sua produção hegemônica. Antes de adentrarmos essa realidade, é válido reconhecer um processo que tornou concentrados os serviços de saúde e a produção nacional de equipamentos médico-hospitalares na formação socioespacial brasileira.

\subsubsection{A formação socioespacial ligada à produção nacional de equipamentos médicos}

Sabemos que o acelerado crescimento das cidades, historicamente, não esteve acompanhado da oferta de serviços públicos capaz de dar condições de vida e trabalho a todos seus habitantes. A grande cidade se tornou abrigo da pobreza e a periferização uma característica do crescimento desigual.

Mesmo que ainda hoje numerosas cidades e extensas periferias pobres são desprovidas de água e esgoto tratado, as tecnologias médicas sofisticadas vêm conformando novas demandas sociais, estimuladas pelos governos.

Como mostrou Santos (1990:46), "é na verdade a combinação do modelo econômico com o modelo cívico que é a matriz do empobrecimento, das migrações galopantes, da urbanização caótica, da degradação das condições de existência”.

No Brasil, a indústria de equipamentos médico-hospitalares data da década de 1950, período em que o país dá impulso ao seu processo de industrialização. Instalam-se empresas de materiais de consumo, produtoras de artigos de complexidade baixa, como agulhas e seringas. 
Mais a frente, também aparelhos de anestesia passam a ser fabricados no país e, na década seguinte, surgem os primeiros fabricantes de instrumentos cirúrgicos.

A divisão internacional do trabalho vem imprimir novos contornos à expansão do sistema capitalista e, a partir da segunda metade do século XX, a internacionalização do território nacional se torna uma tendência ligada às modernizações técnicocientíficas.

0 Estado brasileiro assume a criação de condições internas para receber os novos vetores externos, condições estas que vão do planejamento territorial e crescimento econômico à ideologia do consumo. 0 desenvolvimento dos meios de transporte e a expansão demográfica compunham o processo de desenvolvimento econômico e rápido crescimento urbano do país.

São Paulo é a grande beneficiária na difusão seletiva das modernizações, concentrando grande parte das forças produtivas. Ao mesmo tempo, o país tendia a uma generalização do fenômeno da urbanização, proliferando as cidades de menor porte e fazendo crescer as cidades maiores.

Neste contexto, a criação do sistema previdenciário no país repercutiu diretamente na lógica dos serviços de assistência médica da época. Como observou Almeida (2005), a institucionalização da assistência individual e o estímulo às ações curativas foram causas do direcionamento da transformação do hospital num símbolo nacional da inovação e da competência da cura.

A população empregada nas indústrias desencadeava uma expansão da demanda, que canalizava a renda arrecadada com a previdência para o gasto em saúde. 0 sistema de reembolso, quando o provedor da assistência era privado, fazia aumentar também o gasto privado em saúde, através das empresas de seguro médico.

Os hospitais do país e a indústria nacional cresciam mutuamente concentrados na região de maior dinamismo econômico, São Paulo e a indústria de equipamentos médicos-hospitalares integrava, assim, o impulso nacional de internalização da nova divisão internacional do trabalho. 
A densificação e diversificação das divisões territoriais do trabalho que consolidavam a metrópole de São Paulo eram estímulo para o florescimento e afirmação das pequenas indústrias de equipamentos médicos. Ao passo em que a produção nacional servia, sobretudo, ao mercado interno, os hospitais nos centros dinâmicos do país eram aparelhados com decisivo apelo tecnológico.

o mecanismo previdenciário de compra de serviços hospitalares e médicos foi fator importante no surgimento dos hospitais próprios da previdência. Como nos explica Almeida (2005), esses hospitais foram a porta para inserir a medicina brasileira na moderna tecnologia hospitalar.

Agente num processo denominado de capitalização da saúde, o Estado provia e pagava a ampliação da demanda aos médicos e aos produtos industriais vinculados à promoção da saúde; financiava os investimentos e contratava os serviços da rede privada, apoiando assim os empreendimentos capitalistas no setor (Braga \& Silva, 2001:20).

Neste sentido, a partir da década de 1970, a indústria de equipamentos médicos passou a produzir equipamentos de tecnologia mais complexa, como os aparelhos eletro-eletrônicos. É quando nascem as empresas nacionais produtoras de aparelhos de raio-x, instrumentos de laboratório, eletromédicos e monitoração, dialisadores e oxigenadores, válvulas cardíacas e marcapassos.

Neste período, podemos dizer que os governos militares defenderam diretamente a assistência médico-hospitalar privada e a ampliaram. Os serviços de saúde, estimulados pelo sistema previdenciário, privilegiaram os trabalhadores urbanos inseridos no mercado de trabalho, influenciando a localização dos hospitais melhor equipados do território nacional.

Esse processo foi determinante para que tenha havido uma concentração da rede médico-hospitalar nos centros mais dinâmicos do país. Os trabalhadores e as indústrias, concentrados na região metropolitana de São Paulo, estimulavam uma demanda também concentrada pelo consumo em saúde e pela produção de equipamentos médicos.

Contudo, grande parcela da população permanecia excluída de qualquer proteção social e estava relegada a viver os efeitos 
das modernizações, criando novas demandas de um mercado segmentado.

Em contrapartida, a preocupação pelos interesses das parcelas empobrecidas fortalecia a corrente médico-sanitária. Nesse caminho, fazer valer a saúde como direito se tornava uma longa jornada de luta política no país, cuja conquista culminou na constituição de 1988, quando a saúde vem integrar o projeto político de democratização do país.

Fato é que os interesses privados já estavam imbricados e as estruturas oligopolísticas já estabelecidas no território. A indústria farmacêutica, a indústria de equipamentos médicohospitalares, os laboratórios, os hospitais, as empresas médicas, o setor financeiro, combinavam e influenciavam fortemente a organização dos serviços de assistência médica e a formação dos profissionais da saúde no país.

Este processo histórico constitui a base material sobre a qual se dão os processos mais recentes das políticas de saúde. Nesse sentido, o território é uma norma da qual se vale uma economia da saúde que se abriga em algumas cidades que constituem essa realidade.

Daí que a diversificação das empresas nacionais de equipamentos médicos foi dinamizada pelo mercado interno. Na década de 1980, houve um marco importante para produção nacional de equipamentos médico-hospitalares. A política de reserva de mercado estabelecida para o setor de informática foi estendida à indústria de eletromédicos, pela sua estreita ligação com as tecnologias informáticas.

Por um lado, as indústrias estrangeiras que vinham instalando unidades produtoras de equipamentos complexos são afugentadas (NEPP, 2000:18) transformando-se em importadoras e prestadoras de assistência técnica. Por outro lado, a Lei de Informática ${ }^{31}$ -

${ }^{31} \mathrm{O}$ setor de informática foi regulado inicialmente pela Lei 7.232/84, que estabeleceu a reserva de mercado para o setor. Em 1991, a Lei 8.248 pôs fim à reserva, mas diminuiu a porcentagem do Imposto sobre Produto Industrializado cobrado se a empresa investisse $5 \%$ do faturamento em Pesquisa e Desenvolvimento. Os benefícios iriam até 1999. A Lei foi reeditada em 2001, sob o número 10.176. O prazo de concessão dos benefícios foi novamente estendido, até 2009. A obrigação dos investimentos em Pesquisa e Desenvolvimento foi mantida, assim como o porcentual de $5 \%$ e redução no mesmo imposto. A principal alteração, de acordo com especialistas, foi a exigência de que parte dos investimentos fosse direcionada para as regiões Norte, Nordeste e Centro-Oeste. A lei também criou o Fundo Setorial de Informática. A empresa terá maior redução do imposto se, além de fazer $\mathrm{P} \& \mathrm{D}$, também produzir nessas 
Lei $7.232 / 84$ beneficiou os fabricantes nacionais da indústria de eletromédicos, consolidando algumas empresas nacionais no fornecimento destes aparelhos ao sistema de saúde do país.

A abertura comercial, ocorrida na década seguinte, entretanto, expõe a debilidade da indústria nacional, sobretudo, por não ter havido mediação de uma política que estivesse atenta à proteção da produção nacional de bens que correspondiam às necessidades do serviço público de saúde. A própria reedição da lei de informática pode ser vista como fator nesse processo.

$\mathrm{Na}$ década de 1990, o acelerado avanço tecnológico no plano internacional, a dependência tecnológica já estabelecida, a facilidade de importar os insumos, além da entrada de equipamentos importados de alta complexidade tecnológica davam o contexto que fazia crescer o déficit da indústria nacional e a dependência dos investimentos estrangeiros.

A tabela seguinte mostra, em 1996, a distribuição concentrada das atividades produtivas de equipamentos médicos nas regiões Sul e Sudeste do país, quando vemos que quase $10 \%$ das unidades produtivas se encontram fora desses Estados. Vemos ainda que tais atividades estão, sobretudo, no Estado de São Paulo.

TABELA 4 - Unidades produtivas de equipamentos médico-hospitalares nos Estados das Regiões Sul e Sudeste (exceto Espírito Santo) - Brasil, 1996

\begin{tabular}{|c|r|r|r|r|r|r|r|}
\hline $\begin{array}{c}\text { CNAE 33.1 } \\
1996\end{array}$ & Brasil & Minas Gerais & $\begin{array}{c}\text { Rio de } \\
\text { Janeiro }\end{array}$ & São Paulo & Paraná & $\begin{array}{c}\text { Santa } \\
\text { Catarina }\end{array}$ & $\begin{array}{c}\text { Rio } \\
\text { Grande } \\
\text { do Sul }\end{array}$ \\
\hline Unidades & 589 & 82 & 66 & 308 & 37 & 11 & 26 \\
\hline Pessoal Ocupado & 19.894 & 2.549 & 3.591 & 10.582 & 735 & 582 & 575 \\
\hline
\end{tabular}

Fonte: IBGE, Pesquisa Industrial, 1996

regiões. No final de 2004, o governo sancionou a Lei 11.077, que substituiu a 10.176/01. A nova Lei de Informática mantém a exigência do cumprimento do Processo Produtivo Básico, que regula sobre as etapas da produção a se realizar no país, e coloca a não obrigatoriedade que os produtos fabricados no Brasil sejam desenvolvidos aqui, mas cria um adicional para produtos também feitos localmente. A lei fez a seguinte divisão: se o produto é feito no país, nas regiões Sul ou Sudeste, conta com redução de 80\% de IPI; caso isso ocorra no Norte, Nordeste e Centro-Oeste, a redução é de 95\%. Para produtos que são desenvolvidos e fabricados aqui, o porcentual é maior: nas regiões Sul e Sudeste, é de 95\%, e para o Norte, Nordeste e Centro-Oeste, a empresa se torna isenta do pagamento de IPI sobre o produto fabricado. Esses porcentuais valem até 2014, quando serão reduzidos progressivamente até a extinção dos mesmos, que ocorrerá em 2019. Segundo especialistas, o objetivo é aproveitar a tendência de descentralizar as atividades de Pesquisa e Desenvolvimento em curso no país e atrair os interesses de pesquisa das multinacionais para projetos de inovação de produtos que serão vendidos no país e em outros mercados. 
TABELA 5 - Unidades produtivas de equipamentos médico-hospitalares, nos Estados das Regiões Sul e Sudeste (exceto Espírito Santo) - Brasil, 2000

\begin{tabular}{|c|r|r|r|r|r|r|r|}
\hline $\begin{array}{c}\text { CNAE 33.1 } \\
2000\end{array}$ & Brasil & \multicolumn{1}{|c|}{$\begin{array}{c}\text { Minas } \\
\text { Gerais }\end{array}$} & \multicolumn{1}{|c|}{$\begin{array}{c}\text { Rio de } \\
\text { Janeiro }\end{array}$} & São Paulo & Paraná & $\begin{array}{c}\text { Santa } \\
\text { Catarina }\end{array}$ & $\begin{array}{c}\text { Rio } \\
\text { Grande do } \\
\text { Sul }\end{array}$ \\
\hline Unidades & 556 & 52 & 39 & 234 & 45 & 14 & 27 \\
\hline $\begin{array}{c}\text { Pessoal } \\
\text { Ocupado }\end{array}$ & 20.727 & 2.136 & 771 & 10.000 & 1282 & 738 & 435 \\
\hline
\end{tabular}

Fonte: IBGE, Pesquisa Industrial, 2000

Quando damos atenção para o período entre 1996 e 2000, podemos observar uma queda das unidades produtivas nos Estados da região Sul e Sudeste, enquanto há um incremento considerável, de 59 para 145 unidades nas outras regiões do país.

Nesse contexto dos anos 1990, apenas aquelas empresas de equipamentos médicos que conseguiram obter maior organização dentro do novo momento produtivo resistiram ao impacto da abertura comercial e da valorização da moeda.

Ao passo em que vemos a mortalidade de muitas empresas que não foram capazes de acompanhar a evolução tecnológica em curso, podemos compreender melhor porque as empresas mais antigas são também as maiores empresas do país e, como dissemos antes, aquelas com maior capacidade tecnológica e, cuja inserção no mercado internacional é maior.

Esse processo pode, então, ser explicado pela abertura econômica da década de 1990 que, de um lado, facilitou o aumento da divisão territorial do trabalho e, com efeito, o surgimento de novas atividades no país. Por outro, fez com que muitas atividades não conseguissem se inserir no novo momento produtivo, diante das novas acelerações.

É importante ressaltar o programa REFORSUS nesse processo. No final de 1996, o REFORSUS foi lançado pelo Ministério da Saúde para realizar investimentos na recuperação da rede física de saúde do país. Tal empreendimento contou com o Banco Interamericano de Desenvolvimento (Bird) e o Banco Mundial, com recursos da ordem de US\$650 milhões.

Esse programa refere-se à compra de equipamentos médicos e unidades móveis (ambulâncias), obras de reforma nos 
estabelecimentos, beneficiando hospitais públicos e filantrópicos. Com 1.175 projetos aprovados, sabemos que não houve qualquer orientação em benefício dos equipamentos nacionais.

As conseqüências desse evento são estruturais. Não poderemos medir, todavia é sabido do poder cumulativo da capacidade já instalada diante dos investimentos e, sobretudo, a desestruturação da capacidade produtiva nacional.

Vemos pelas tabelas que o que foi um incremento nos outros estados entre 1996 e 2000, não mantém a progressão entre 2000 a 2005, enquanto os estados da Região Concentrada mostram haver condições para o surgimento acelerado de atividades produtivas de equipamentos médicos.

TABELA 6 - Unidades produtivas de equipamentos médico-hospitalares, nos Estados das Regiões Sul e Sudeste (exceto Espírito Santo) - Brasil, 2005

\begin{tabular}{|c|r|r|r|r|r|r|r|}
\hline $\begin{array}{c}\text { CNAE 33.1 - } \\
\mathbf{2 0 0 5}\end{array}$ & Brasil & \multicolumn{1}{|c|}{$\begin{array}{c}\text { Minas } \\
\text { Gerais }\end{array}$} & \multicolumn{1}{c|}{$\begin{array}{c}\text { Rio de } \\
\text { Janeiro }\end{array}$} & São Paulo & Paraná & $\begin{array}{c}\text { Santa } \\
\text { Catarina }\end{array}$ & $\begin{array}{c}\text { Rio } \\
\text { Grande } \\
\text { do Sul }\end{array}$ \\
\hline Unidades & 747 & 72 & 63 & 386 & 51 & 23 & 47 \\
\hline $\begin{array}{c}\text { Pessoal } \\
\text { Ocupado }\end{array}$ & 25.318 & 2.173 & 3.329 & 13.481 & 1.666 & 1.034 & 1.345 \\
\hline
\end{tabular}

Fonte: IBGE, Pesquisa Industrial, 2005.

Nos três mapas que se seguem, poderemos observar essa progressão de 1996 a $2005^{32}$. Observamos que o incremento das

32 Os dados referentes aos anos posteriores a 2005, não puderam ser trabalhados de modo agregado por conta da mudança da classificação nacional das atividades ligadas aos equipamentos médico-hospitalares. Aqui devemos parar para tratar do problema que temos para classificar os segmentos industriais do ramo de equipamentos médicos e, nesse sentido, obter e trabalhar os dados. Quando adotamos a classificação em Equipamentos, Dispositivos e Consumíveis, trata-se de empresas hegemônicas mundiais, as quais observamos de um modo geral. Quando adentramos a produção nacional, o problema de classificação se revela profundo por diferentes motivos: i) até a década de 1990, o Instituto Brasileiro de Geografia e Estatística (IBGE) adota uma classificação detalhada do setor de equipamentos médico-hospitalares, onde existiam quatro grupos que dividiam atividades diferenciadas (a. Aparelhos não eletrônicos; b. Aparelhos eletrônicos, partes e acessórios; c. Aparelhos de prótese e órtese; d. Material de consumo). Após a década de 1990, o IBGE adota uma nova forma de classificação, o Cadastro Nacional de Atividades Econômicas (CNAE), de modo a tornar as informações nacionais compatíveis com outras classificações internacionais, como a ISIC-REV3. Nessa nova classificação, ocorre uma assimilação dos três primeiros grupos anteriores na classificação CNAE 33.1, que corresponde à "Fabricação de aparelhos e instrumentos para uso médicohospitalares, odontológicos e de laboratórios e aparelhos ortopédicos”; aquele grupo “d. Material de consumo”, que teve historicamente enorme importância na indústria nacional, passa a fazer parte do setor farmacêutico, classe CNAE 24.54-6. De qualquer maneira, a rápida difusão de tecnologias eletrônicas e novos materiais têm colocado em questão as fronteiras para a classificação dos diferentes produtos da indústria nacional. Daí que, em 2007, o Cadastro 
atividades nas outras regiões não se sustenta entre 2000 e 2005, mostrando a dificuldade das atividades se manterem em regiões com menor densidade técnica e informacional relativamente à Região Concentrada.

Nesse período mais recente, trabalharemos com mais atenção no item subseqüente. Por ora, podemos observar pelos mapas a seguir que o crescimento maior das atividades produtivas de equipamentos médicos no restante do país foi no período entre 1996 e 2000, o que vimos também nas tabelas 5 e 6 .

Já na Região Concentrada, nesse mesmo período entre 1996 e 2000, há uma diminuição das unidades produtivas. No mapa 2 e 3, vemos que o estado de São Paulo, apesar de manter destaque na região Sul e Sudeste, passa a ser menor proporção da diferença em relação ao restante do país.

Se neste período, por um lado, a modernização diversificava e tornava densa a divisão do trabalho no interior das aglomerações, por outro, expandia a pobreza dos grandes centros urbanos, do mesmo modo que estimulava a proliferação de atividades menos modernas e capitalizadas.

Esse processo pode ser verificado na progressão histórica dos mapas, quando reunimos a eles o contexto mais abrangente da formação socioespacial que, desde os anos 1990, se empenha na inserção na divisão internacional do trabalho.

Nacional de Atividades Econômicas passou por nova revisão, substituindo a anterior, CNAE 1.0 pela CNAE 2.0. Tal movimento altera a classificação dos equipamentos médicos, deixando os equipamentos eletromédicos e eletroterapêuticos do restante. A implementação da nova classificação é muito recente, e, embora haja correspondência entre as duas classificações, torna as análises dificultosas, sobretudo no que diz respeito às séries históricas. Ainda mais, o problema se agrava quando a bibliografia recente, dado o interesse recente pela atividade, sejam os estudos documentais do governo federal e do estado de São Paulo, as informações das entidades representantes da atividade produtiva, aponta diferentes critérios de classificação, a depender do interesse que têm para mostrar os números. Por exemplo, podemos encontrar dados com ou sem a fabricação de termômetros, ataduras, com ou sem cadeira de rodas, móveis hospitalares, com ou sem lavadora de roupas, como ou sem instrumentos odontológicos, com ou sem próteses e órteses, apenas com aparelhos eletromédicos e assim por diante. Nesse sentido, a bibliografia com a qual tivemos contato mostra que cada estudo termina por adotar o que lhe parece mais adequado. Mais um complicador nesse debate, é que nem sempre o mercado de destino desses produtos é exclusivamente a saúde, como é o caso dos equipamentos e insumos laboratoriais destinados aos mercados científico e industrial. Por outro lado, esse processo no interior das questões de padronização internacional e do crescimento da produção nacional é revelador da dinâmica e heterogeneidade tecnológica existente entre as indústrias que servem à dimensão da saúde. 
Daí o sistema produtivo de equipamentos médicos no país ter uma constituição efetiva de micro e pequenas empresas, sendo que as grandes empresas, com mais de 500 funcionários, representam menos de $10 \%$ da produção nacional ${ }^{33}$.

É sobretudo na cidade de São Paulo que são criadas muitas pequenas empresas fabricantes de equipamentos médicos, assim como no estado como um todo relativo ao restante do país. Entretanto, ainda que a nova classificação nacional desagregue essas atividades a partir de 2007, vale observar alguns detalhes.

TABELA 7 - Unidades produtivas de equipamentos médico-hospitalares, com 5 ou mais pessoas ocupadas - Brasil, Sul e Sudeste (exceto Espírito Santo) - 2007 e 2008

\begin{tabular}{|c|c|c|c|c|c|c|c|c|}
\hline \multirow[t]{2}{*}{ CNAE 26.6} & \multicolumn{2}{|c|}{$\begin{array}{l}\text { Número de } \\
\text { Unidades }\end{array}$} & \multicolumn{2}{|c|}{ Pessoal Ocupado } & \multicolumn{2}{|c|}{$\begin{array}{l}\text { Receita Líquida de } \\
\text { Vendas (mil R\$) }\end{array}$} & \multicolumn{2}{|c|}{$\begin{array}{c}\text { Valor da } \\
\text { Transformação } \\
\text { Industrial (mil R\$̣) }\end{array}$} \\
\hline & 2007 & 2008 & 2007 & 2008 & 2007 & 2008 & 2007 & 2008 \\
\hline Brasil & 228 & 226 & 5.777 & 5.948 & 681.601 & 692.216 & 370.763 & 393.843 \\
\hline Minas Gerais & 31 & 22 & 488 & 488 & 58.100 & 65.735 & 33.222 & 33.444 \\
\hline Rio de Janeiro & 21 & 22 & 579 & 648 & 40.244 & 43.541 & 22.841 & 21.635 \\
\hline São Paulo & 87 & 111 & 3.428 & 3.647 & 487.246 & 486.706 & 255.198 & 277.010 \\
\hline Paraná & 35 & 24 & 519 & 431 & 30.002 & 22.339 & 15.165 & 11.295 \\
\hline Santa Catarina & 5 & 6 & - & - & - & - & - & - \\
\hline $\begin{array}{c}\text { Rio Grande do } \\
\text { Sul }\end{array}$ & 19 & 16 & 250 & 279 & 26.615 & 30.868 & $17 \cdot 312$ & 19.122 \\
\hline
\end{tabular}

Fonte: IBGE, Pesquisa Industrial, 2007 e 2008

Como dissemos, o grupo CNAE 33.1 reunia uma diversidade de equipamentos médicos e, desde 2007, o grupo CNAE 26.6 agrega apenas os equipamentos eletromédicos. Não podemos apontar muitos detalhes dessa tabela, mas é válido observar a diminuição das empresas em Minas Gerais, com o mesmo número de funcionários e receita líquida maior.

Essa relação parece se referir ao processo de aquisição e fusão de empresas menores diante da abertura para a instalação de multinacionais, como a Philips e a GE. Apontaremos essas questões no próximo item.

33 Em 2001, 80\% do total de empresas é formado por capital nacional (Furtado e Souza, 2001:66), enquanto em 2009, esse dado é de 90\%, de acordo com a ABIMO. 
MAPAS 2, 3, 4 - Número de unidades industriais de equipamentos médicohospitalares no Brasil (com destaque para a Região Concentrada, exceto Espírito Santo) - Brasil, 1996 - 2005

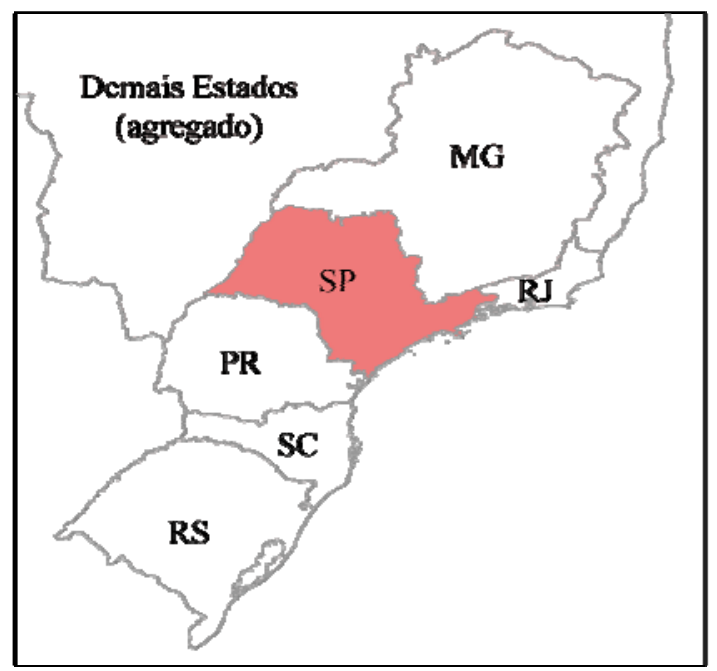

1996

Unidades locais industriais por Unidade da Federaçấo
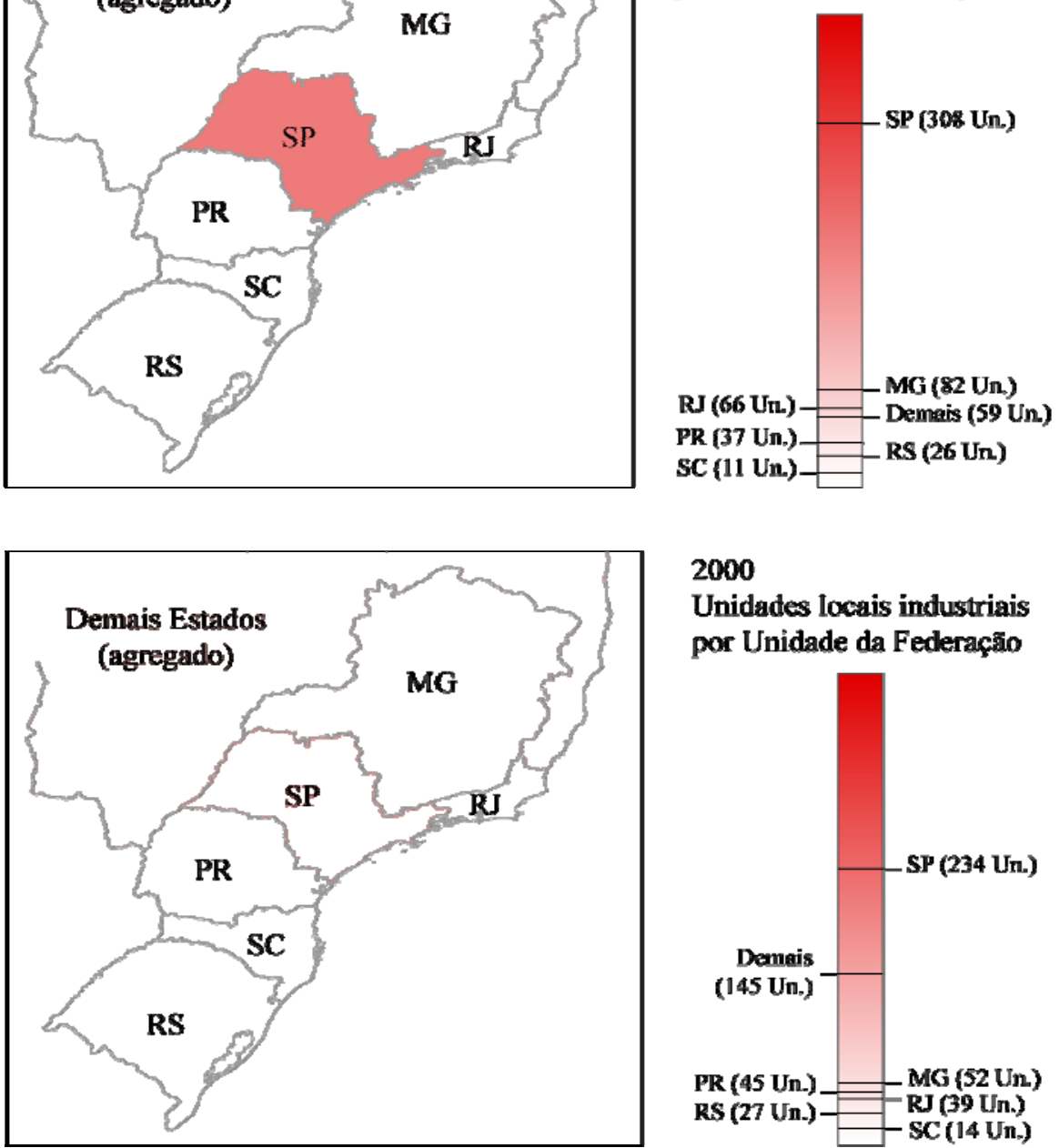

2000

Unidades locais industriais por Unidade da Federação

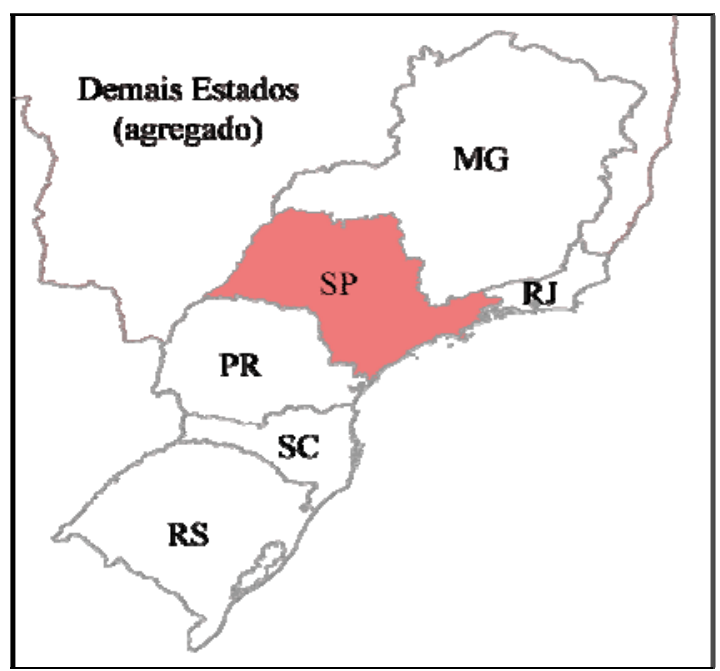

2005

Unidades locais industriais por Unidade da Federaçån

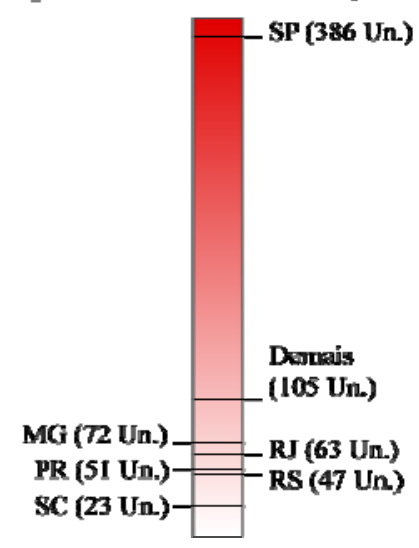


As maiores cidades, com um mais denso tecido de relações inter e intra-urbanas, se mostram como oportunidades para uma diversidade de agentes, e, enquanto cidades que abrigam uma economia de aglomeração relacionada às demandas da saúde, autorizam maior complexidade dos circuitos da economia urbana ligado aos equipamentos médicos.

A dinamização do mercado interno e expansão da demanda de produtos fabricados no país, o aumento das demandas em saúde e o crescimento de um terciário terapêutico, nas últimas décadas, são tanto expressão quanto motivação da dinâmica dessas economias urbanas.

Neste sentido, muitos dos agentes da produção nacional puderam se especializar em produtos com pouca tecnologia e se manterem importantes na oferta nacional. Enquanto, a produção de equipamentos mais complexos, como os eletroeletrônicos, mantevese apenas entre aquelas empresas nacionais mais capitalizadas.

Apoiadas pela regulação da Lei de Informática, alguns agentes nacionais puderam reorganizar sua produção e especializá-la, como estratégia num mercado mundializado. Enquanto outros se beneficiaram da possibilidade de importação de insumos para produzirem objetos relativamente mais complexos.

Em alguns segmentos, mesmo sendo pequenas as empresas, são empresas dominantes no mercado interno, como a Drake de Ribeirão Preto, empresa que possui 25 anos e, antes em São Paulo, hoje sediada em São José do Rio Preto com menor número de funcionários, produz analisadores de gases sanguíneos, cujo mercado está em todo o Brasil.

Nessa direção, as empresas nacionais estão constituídas em vários dos segmentos industriais de equipamentos médicos de menor nível tecnológico, apresentando uma ampla oferta de produtos à variedade das necessidades instrumentais dos hospitais, clínicas, postos de saúde do país.

Vale ressaltar que haverá certa dificuldade em que as políticas de estímulo e apoio às indústrias de equipamentos médicos do país sejam capazes de abranger e beneficiar as empresas em sua diversidade. 


\subsubsection{Processo de urbanização e modernização seletiva}

A divisão internacional do trabalho toma proveito da divisão territorial do trabalho da nação. Comandada por um subsistema hegemônico determinante, a força sistêmica para propor e transformar os lugares a sua conveniência provém desse poder globalizado de algumas empresas.

Pois é dessa forma que o processo de urbanização é atrelado às possibilidades de articulação que a dinâmica da circulação promove. Enquanto, a circulação de ordens, de mais-valia, de informação toma a frente da organização dos processos sociais, surgem novos processos de diferenciação dos lugares.

À medida que esse novo sistema temporal baseado numa produção técnico-científica e informacional organiza e transforma o meio geográfico, a divisão interna do trabalho em algumas cidades se densifica, aumentando a complexidade com a qual se relacionam as formas de trabalho.

o país conhece a partir da década de 1970 um processo de metropolização, com o aumento do número de cidades milionárias e de cidades de porte médio (em torno de meio milhão de habitantes). Santos e Silveira (2001:203) nos mostram que "aumenta o número de cidades locais e sua força, assim como o dos centros regionais, ao passo que as metrópoles regionais tendem a crescer relativamente mais que as próprias metrópoles do Sudeste”.

A tabela seguinte mostra que cresce o número de cidades grandes, mas também o organismo urbano é maior, mostrando que a rede urbana é cada vez mais diferenciada, ao passo em que se torna também mais complexa suas inter-relações.

TABELA 8 - Tendência à metropolização no Brasil, 1950 - 1996

\begin{tabular}{|l|l|l|l|l|l|l|}
\hline & 1950 & $\mathbf{1 9 6 0}$ & $\mathbf{1 9 7 0}$ & $\mathbf{1 9 8 0}$ & $\mathbf{1 9 9 1}$ & $\mathbf{1 9 9 6}$ \\
\hline Entre 100 e 200 mil habitantes & 4 & 18 & 38 & 56 & 78 & 90 \\
\hline Entre 200 e 500 mil habitantes & 5 & 6 & 15 & 32 & 45 & 61 \\
\hline Mais de 500 mil habitantes & 3 & 4 & 8 & 13 & 22 & 24 \\
\hline Total com mais de 100 mil habitantes & 12 & 28 & 61 & 101 & 145 & 175 \\
\hline Mais de 1 milhão de habitantes & 2 & 2 & 5 & 9 & 9 & 12 \\
\hline
\end{tabular}

Fonte: Santos, M e Silveira, M L. O Brasil - território e sociedade no início do século XXI, Ed. Record, Rio de Janeiro, 2001, p.208 
Esse processo é intrínseco ao aumento da quantidade de trabalho intelectual, necessário ao novo momento do processo produtivo (Santos, 2005:91), pois "as cidades de porte médio passam a acolher maiores contingentes de classes médias e de letrados, indispensáveis a uma produção material, industrial e agrícola, que se intelectualiza.” (Santos e Silveira, 2001:203)

Nesse sentido, podemos observar o fenômeno da metropolização, processo cumulativo das maiores cidades do país como um processo interdependente e concomitante à desmetropolização (Santos, 1993), definida como a repartição com outros grandes núcleos de novos contingentes de população urbana.

Enquanto as metrópoles regionais tendem a crescer relativamente mais que as próprias metrópoles do Sudeste, com um crescimento econômico metropolitano menor do que o das áreas atingidas pela modernização tecnológica e científica, vemos a expansão da pobreza, observada pela "baixa do rendimento médio e expansão do número de empregos mal remunerados" (Santos e Silveira, 2001).

Vemos que esse fenômeno de metropolização e desmetropolização está vinculado à redistribuição da classe média, paralelamente a dos pobres, no território nacional. Por sua vez, os desenhos da rede urbana respondem à redistribuição geográfica dos fatores de produção, dos homens, dos produtos, das mensagens, dos capitais na sua forma de dinheiro e outras formas.

Nesse fenômeno conjunto de metropolização e desmetropolização, em que se revela a respeito da possibilidade generalizada de produção e difusão das modernizações e seu modo de existência, vemos a forma como a nova divisão territorial do trabalho atinge a própria região concentrada.

"Se muitas variáveis modernas se difundem amplamente sobre o território, parte considerável de sua operação depende de outras variáveis geograficamente concentradas. Dispersão e concentração dão-se, uma vez mais, de modo dialético, de modo complementar e contraditório." (Santos, 2005:101)

As grandes cidades que, antes, eram consideradas únicos lugares adequados ao crescimento, hoje dividem esse potencial com outras cidades menores. Áreas portadoras de um arranjo de objetos de épocas pretéritas, como algumas cidades do Estado de São Paulo que conhecem um incremento populacional nas últimas 
décadas, passam a compor novo papel na divisão territorial do trabalho do país.

Em Campinas, Ribeirão Preto e São José do Rio Preto, entre 1991 e 2007, vemos o crescimento demográfico nas três cidades. Em 2007, vemos a proporção do valor adicionado industrial do município em relação ao Estado de São Paulo e o Brasil.

TABELA 9 - População e Valor Adicionado Industrial de Campinas, Ribeirão Preto e São José do Rio Preto

\begin{tabular}{l|c|c|c|c|c|c|c}
\hline \hline & $\begin{array}{c}\text { População } \\
\mathbf{1 9 9 1}\end{array}$ & $\begin{array}{c}\text { População } \\
\mathbf{1 9 9 6}\end{array}$ & $\begin{array}{c}\text { População } \\
\mathbf{2 0 0 0}\end{array}$ & $\begin{array}{c}\mathbf{2 0 0 7} \\
\text { (estimada) }\end{array}$ & $\begin{array}{c}\text { Valor } \\
\text { Adicionado } \\
\text { Industrial } \\
\mathbf{2 0 0 7}\end{array}$ & $\begin{array}{c}\text { Valor } \\
\text { Adicionado } \\
\text { Industrial SP } \\
\mathbf{2 0 0 7}\end{array}$ & $\begin{array}{c}\text { Valor } \\
\text { Adicionado } \\
\text { Industrial } \\
\text { Brasil } \\
\mathbf{2 0 0 7}\end{array}$ \\
\hline Campinas & 847.595 & 903.462 & 969.396 & 1.039 .297 & 5.328 .059 & 193.980 .716 & 539.315 .998 \\
\hline $\begin{array}{l}\text { Ribeirão } \\
\text { Preto }\end{array}$ & 436.682 & 453.752 & 504.923 & 547.417 & 2.073 .134 & 2.073 .134 & 2.073 .134 \\
$\begin{array}{l}\text { São José } \\
\text { do Rio } \\
\text { Preto }\end{array}$ & 283.761 & 324.492 & 358.523 & 402.770 & 814.795 & 814.795 & 814.795 \\
\hline \hline
\end{tabular}

Fonte: IBGE, canal: cidades@ - acesso em 23/og/og http://www.ibge.gov.br/cidadesat/topwindow.htm?1

Campinas, Ribeirão Preto e São José do Rio Preto, ainda que suas diferenças sejam incomparáveis, são três cidades com importantes papéis na produção industrial de equipamentos médicos no país. Abrigam um número significativo de fabricantes, assim como representam significativa participação na produção nacional, dado que mais da metade desta se realiza no estado de São Paulo.

TABELA 10 - Empresas fabricantes de equipamentos médicos-hospitalares (CNAE 1.0/ 33.1) no Estado de São Paulo, por cidade - 2005

\begin{tabular}{c|c|c}
\hline Cidades & Unidades & $\begin{array}{c}\text { Pessoal } \\
\text { ocupado }\end{array}$ \\
\hline São Paulo & 205 & 3.794 \\
\hline Ribeirão Preto & 47 & 1.217 \\
\hline Campinas & 20 & 286 \\
\hline Piracicaba & 13 & 180 \\
\hline Rio Claro & 13 & 550 \\
\hline São Carlos & 12 & 278 \\
\hline S. J. Rio Preto & 11 & 715 \\
\hline Araraquara & 9 & 128 \\
\hline Diadema & 9 & 322 \\
\hline
\end{tabular}

\begin{tabular}{c|c|c}
\hline S. B. do Campo & 9 & 49 \\
\hline Sorocaba & 8 & 532 \\
\hline Barueri & 7 & 178 \\
\hline Osasco & 7 & 116 \\
\hline S. J. Campos & 7 & 132 \\
\hline Guarulhos & 6 & 231 \\
\hline Batatais & 5 & 27 \\
\hline Mogi das Cruzes & 5 & 127 \\
\hline Taubaté & 5 & 18 \\
\hline
\end{tabular}

Fonte: RAIS 2005 
A distribuição geográfica das cidades com maior número de empresas fabricantes de equipamentos médicos revela a influência dos sistemas de movimento rodoviário na localização das pequenas e grandes firmas industriais de equipamentos médicohospitalares.

As três cidades são nós de uma infra-estrutura existente no Estado de São Paulo, onde há uma densa e moderna malha rodoviária intra e interestadual. Ainda, Campinas se destaca pelo aeroporto, segundo maior terminal de carga do país.

O governo do Estado de São Paulo, em dezembro de 2008, através do decreto n. 50.504 de fevereiro de 2006, criou o Sistema Paulista de Parques Tecnológicos (SPTec). Cinco parques tecnológicos estão em fase de implantação: São José dos Campos, Campinas, Piracicaba, Ribeirão Preto e São Carlos.

Outras sete iniciativas estão também em processo nas cidades de Santos, Praia Grande, Americana, Limeira, Paulínia, São Paulo e São José do Rio Preto. E, para as atividades produtivas ligadas à saúde, esse programa se torna importante evento na dinâmica territorial observada na pesquisa.

o empenho atual do Estado em desenvolvimento da produção industrial anuncia o interesse nas três cidades, Campinas, Ribeirão Preto e São José do Rio Preto, para a modernização da produção. Apresenta-as como espaços já produtivos que vêm conhecer especializações territoriais de uma nova natureza.

0 modo seletivo com que as modernizações tendem a se concentrar em algumas cidades mostra que essas especializações territoriais são a passagem de aglomerações urbanas à execução de novas funções produtivas. 0 que revela, também, a redistribuição da população urbana.

o processo de urbanização que nesse sentido se acelera, torna maior o papel de algumas cidades pela possibilidade de aplicação da ciência e da técnica à produção e à circulação como um todo. As três cidades representantes importantes da produção nacional de equipamentos médicos ganham relevo.

Ao passo em que há a dissolução da metrópole de São Paulo no território nacional, como explicam Santos e Silveira (2001:141), vemos que São Paulo se torna metrópole informacional, dada pela 
capacidade de comando da cooperação necessária entre cada pedaço do território (Bernardes, 2001).

Da mesma forma, a densa e diversificada divisão do trabalho na Região Concentrada desponta tal espessura, técnica e política, por uma intensidade de movimentos internos, quando comparados com outras áreas do país. o que revela maior divisão interurbana do trabalho na região.

A especialização espacial impõe uma intensificação de atos de comércio - de um comércio feito à distância - que se acompanha do reforço e da expansão do aparelho bancário, parabancário, comercial e administrativo, assim como de meios de armazenamento e transporte. A urbanização resulta disso. As atividades intermediárias abrigadas pelas cidades tornam-se nervo essencial de uma economia cada vez mais capitalista e monetarizada, porque sem a circulação de bens não há circulação do excedente. (Santos, 2003:144)

As atividades modernas presentes em diversos pontos do país se mostram, pois, dependentes de novos fluxos de informação indispensáveis ao processo produtivo, e passam a ter relações privilegiadas com a metrópole São Paulo. Nesse sentido, as multinacionais de equipamentos médicos no país têm, no mínimo, seus escritórios centrais em São Paulo.

\subsection{2.i. 0 circuito superior puro e as grandes empresas de equipamentos médicos no Brasil}

Já vimos que nos Estados Unidos estão as principais indústrias de equipamentos médico-hospitalares (44\% da produção mundial), o principal mercado (45\% das vendas) e o principal pólo exportador desta indústria, inclusive para a América Latina.

Do mercado mundial de equipamentos médico-hospitalares, 4/5 é realizado entre quatro países, Estados Unidos, Alemanha, Japão e França. Os Estados Unidos são dominantes em $45 \%$ do mercado mundial, possuem 13 das 20 maiores empresas mundiais. 0 Japão destaca-se com $18 \%$ do mercado de equipamentos de radiológicos e de ultrasom.

Já a Alemanha, com 11\%, é mais forte pelos equipamentos de imagem e implantes, enquanto a França possui $5 \%$ deste mercado mundial (Braga \& Silva, 2001). Daí vermos que a competitividade 
entre essas empresas é relativa ao subsetor dos equipamentos médicos a que dedicam seus avanços inovativos.

Essa condição norte-americana, explica J. Furtado (2001:45), deve-se à capacidade tecnológica de suas empresas na concepção de novos objetos e do seu sistema produtivo apoiado na regulação no plano doméstico e no acesso aos mercados externos.

Entretanto, vale ressaltar que as exportações americanas reduziram entre 1999 e 2006, de 43\% a quase 27\%, mas não quer dizer que a sua produção vem sofrendo alguma queda, mas sim que as empresas têm intensificado a estratégia de descentralização da produção, instalando plantas em outros países, a partir dos quais abastecem o mercado mundial (ABDI, 2008).

É importante considerar que a dinâmica tecnológica da produção de equipamentos médicos está baseada nos avanços em pesquisa e desenvolvimento de outras áreas do conhecimento, como a mecânica de precisão, a microeletrônica, as tecnologias de informação, além da biotecnologia, biologia molecular, genética, entre outras.

De modo geral, a indústria possui múltiplas categorias de produtos e famílias tecnológicas, de modo que os agentes hegemônicos também se pronunciam num mercado diversificado. No entanto, essas grandes empresas são únicas na fabricação de novos equipamentos, sobretudo de diagnósticos por imagem.

Sinônimos de precisão, esses equipamentos vêm contribuir para a previsão de doenças crônicas, imagens que autorizam análises em tempo real, assim como armazenamento e transmissão de dados do paciente, maior conforto aos pacientes, entre outras vantagens médicas.

Esses agentes multinacionais de equipamentos médicos possuem, portanto, a característica de conceberem, desenvolverem e comercializarem com marca própria seus produtos. Os equipamentos divididos por segmentos de produtos, podem ser, genericamente, equipamentos, dispositivos e consumíveis hospitalares.

Podemos distinguir as grandes empresas por sua estrutura interna organizacional em relação aos segmentos de equipamentos que produz. Este é um dado revelador da organização do espacial da empresa e, com efeito, da escala de ação do seu circuito produtivo. 
De acordo com Ribeiro (2006), as grandes empresas globais de equipamentos médico-hospitalares podem ser diversificadas ou focalizadas. Algumas empresas produzem em vários segmentos, diversificando seus produtos para responder a um conjunto das procuras hospitalares.

São exemplos, as norte-americanas Johnson \& Johnson; a Baxter International; Tyco Healthcare, entre outras. Outras são empresas focalizadas num ou dois segmentos que possuem afinidades funcionais, como a Siemens Medical Solutions, GE Healthcare, Medtronic.

Para o segmento de equipamentos de diagnóstico por imagem e diagnóstico de laboratório, as empresas são focalizadas, isto é, especializadas quase exclusivamente neste segmento, entretanto vale observar que não se trata de empresas unicamente de produtos para a saúde, mas produzem em diferentes setores produtivos.

Ainda mais, o fato de serem especializadas, não significa que produzem um único produto, mas sim que mobilizam um universo em pesquisas para diferenciar produtos e serviços correspondentes dentro do segmento em que têm foco.

Também são focalizadas as empresas que produzem equipamentos de apoio funcional, cuja área dominante é a especialidade cardiovascular, onde estão também presentes como produtoras de dispositivos para cirurgias não invasivas. As empresas que produzem próteses ortopédicas estão também presentes nos segmentos produtores de materiais para tratamentos para feridas e dor.

A indústria de equipamentos médico-hospitalares é, portanto, mundializada. Sua dinâmica para fabricar, montar, distribuir, além das atividades de pesquisa e de marketing é capaz de abraçar o planeta, o que exige um grau de organização junto às variáveis determinantes do período, a tecnociência, a informação e a finança.

No caso que observamos dos equipamentos médicos são essas empresas as próprias criadoras dessas variáveis, mobilizando-as através da dinâmica das inovações. Esse processo de alargamento da ação dos agentes hegemônicos foi observado por Santos (1996) pela transformação dessas variáveis determinantes em variáveis 
dominantes. Graças à divisibilidade atual da técnica, sua difusão é rápida, onde se torna suporte de novas ações.

Detentoras de competências específicas na área das tecnologias de produção, da logística e gestão de redes de fornecimento, as empresas multinacionais de equipamentos médicos oferecem, ainda, soluções integradas, onde os produtos são associados a serviços, como assistência técnica, monitoração de assistência e, ainda, linhas de financiamento para seus produtos.

Apesar de outras áreas do conhecimento serem sustentação para o desenvolvimento dos avanços ligados aos equipamentos médicos, as inovações médicas não são uma consequência automática (Albuquerque e Cassiolato, 2002:142). Isto é, há processos inovativos que ocorrem na própria prática clínica.

Nesse sentido, os aperfeiçoamentos dos objetos, a partir dos usuários, levam a que haja uma aceitabilidade da tecnologia antes de serem difundidos no mercado (Gomes \& Dalcol, 2007). Dessa forma, é importante observar o papel que têm os hospitais e a profissão médica na interação no processo de pesquisa e desenvolvimento e difusão dos equipamentos médico-hospitalares.

Nesse processo em que temos não apenas o alargamento do comércio internacional de equipamentos, mas também a difusão de modelos de produção científica, vemos que "a cada modernização o sistema tende a desdobrar sua nova energia para os subsistemas subordinados" (Santos, 2004:31).

Nessa direção, queremos destacar as multinacionais que possuem atividades no Brasil. Não por acaso, são principalmente aquelas grandes empresas fabricantes de aparelhos de diagnóstico por imagem que atualmente têm se destacado no mercado nacional de equipamentos médicos. Considerado mercado emergente, o Brasil tem intensificado o uso destes aparelhos.

A Siemens, a GE e a Philips agregam atributos comuns: são grandes em tamanho, o que significa intensa divisão interna do trabalho, são diversificadas, por produzirem também noutros ramos industriais, e são internacionalizadas, dada a escala de ação dos seus circuitos de produção.

Neste sentido, a Siemens Medical Solutions, a General Electric Healthcare e a Philips Medical System são apenas as 
divisões produtivas para a saúde, que compreendem uma área estratégica dessas grandes empresas multinacionais.

A Siemens Medical Solution tem sede na Alemanha e produz em três categorias de produtos: Diagnóstico por imagem, Radioterapia e Eletrônica. Em pesquisa e desenvolvimento, a Siemens $M$. S. se sobressai mundialmente na área de medicina molecular.

A detecção precoce das doenças é uma das diretrizes de inovações dessa empresa. Outra é a busca por soluções de produtividade para a redução do tempo de realização de exames. A aplicação clínica do aparelho é outra diretriz, que torna o médico indispensável nos seus laboratórios industriais.

Para a Siemens M. S. a compra de outras firmas, que aparecem como recursos tecnológicos ou industriais complementares à sua atividade em produtos para a saúde (Furtado, 2001:58), é uma prática freqüente de reestruturação do grupo empresarial e alargamento do seu controle espacial.

Internamente, Siemens M. S. possui uma estrutura específica que se dedica a facilitar a compra de seus produtos por meio de financiamentos próprios. É a segunda maior empresa mundial de equipamentos de diagnóstico por imagem e uma das maiores fornecedoras mundiais de objetos técnicos para a saúde.

No Brasil desde 2001, a Siemens M. S. não fabrica no país, mas possui uma organização que lhe permite vender equipamentos sofisticados para cardiologia, neurologia, oncologia e radiologia, assim como plataformas de tecnologia da informação, além de exportar para países da América Latina e África.

Em Wisconsin, nos EUA, há uma grande concentração de competências em equipamentos de diagnóstico por imagem, onde se destaca a General Electric Healthcare, a maior empresa mundial na área de equipamentos médicos. A GE Heathcare também está presente na Holanda e Baviera, onde predominam a produção no segmento de diagnóstico por imagem.

Em termos de desenvolvimento de produtos, a empresa procura incorporar novas funções aos produtos já existentes e aprimorar as antigas, o que atesta sua especialização. Ainda mais, oferece uma gama de produtos nos quais os serviços são integrados (Furtado, 2001:58). 
A GE H. também vem se fundindo com outras empresas grandes, como na Inglaterra e na Finlândia. Recentemente, a empresa estabeleceu sua primeira unidade industrial na América do Sul, localizada no Brasil, em Contagem, Minas Gerais.

A planta brasileira será destinada inicialmente à produção de raio $x$ e mamografia, mas também as linhas de tomografia computadorizada e PET/CT, sendo este $O$ equipamento mais sofisticado que existe para o diagnóstico do cancer, doenças do coração, por preverem distúrbios de funções celulares antes de mudanças anatômicas.

o discurso da instalação se fundamenta no aumento da possibilidade de acesso, dado pela diminuição dos impostos e de logística no preço dos equipamentos, o que traria aumento da qualidade dos serviços de saúde.

Até 2015 é dito que a empresa criará 750 novos empregos diretos e indiretos. Com essa nova planta industrial, houve o lançamento do primeiro centro de treinamento no país, focado na formação de uma mão-de-obra local para qualificar fornecedores em padrões de qualidade.

Veremos que esse movimento é consonante com as prioridades do governo no que diz respeito à capacitação e incentivo à pesquisa e desenvolvimento por parte dos produtores nacionais. Nesse sentido, a empresa diz que dessa forma promoverá a transferência tecnológica para os fornecedores locais, auxiliando o fomento da indústria nacional, também para se transformarem em exportadores.

A chegada dessa fábrica representa uma grande mudança na divisão territorial do trabalho no país. E ainda, por tomar o Brasil como uma plataforma de exportação para os países da America Latina e outros, observamos a pretensão do alcance dessa nova fábrica, deixando evidente o poder do circuito superior na macroorganização do território.

Vale ressaltar que a GE $H$. alega a vantagem de que essa planta industrial se dedicada também ao reparo de aparelhos recondicionados, já que a venda desses equipamentos vem crescendo no país e América Latina nos últimos seis anos.

Acompanhado do discurso das empresas - de que o aparelho recondicionado é a porta para que muitos estabelecimentos de 
saúde possam se beneficiar das tecnologias modernas - a GE, assim como a Siemens já atuam nesse mercado no Brasil. Todavia, vemos que a ocupação desse mercado pelas empresas hegemônicas diminui a possibilidade de que agentes não-hegemônicos continuem a se valer dos $40 \%$ do mercado intersticial de consertos que já não lhes sobra.

Sabemos não ser possível admitir de modo simples que o aparelho recondicionado é a porta de entrada para a melhoria dos serviços de saúde. Esses objetos demandam gastos enormes em insumos para exames, para manutenção, para os recursos humanos capazes de opera-los.

De modo que os hospitais menos modernos ou os serviços de saúde das cidades menores preferem enviar seus pacientes aos serviços mais próximos do que estimular tais atividades, consideradas despesas em suas cidades. Nesse sentido, vemos que - aparelho recondicionado, para além da sua virtualidade médica, se torna mais um mecanismo de oligopolização da economia.

Da mesma forma, podemos dizer a respeito dos mamógrafos, que sabemos, no Brasil são subutilzados. Como apontou a auditoria do Tribunal de Contas da União entre maio de 2008 e abril de 2009, há uma baixa produtividade de exames no país por falta de manutenção e de funcionários para operá-los, além de outros problemas de infra-estrutura ligados à demanda do equipamento por um ambiente específico.

Já a Philips M. S. possui sede na Holanda e é, em termos de vendas, a terceira maior empresa de equipamento de diagnóstico de imagem e a sétima maior empresa de equipamentos médicos do mundo. Nos EUA, em Connecticut/Massachusetts, região de concentração de indústrias biomédicas, a Philips M. S. possui relevo na área de equipamentos de diagnóstico por imagem.

A Philips M. S. inaugurou em outubro de 2008 a primeira fábrica de aparelhos de ressonância magnética da América Latina, planta esta que produzirá no país, pela primeira vez, equipamentos de tomografia computadorizada. Entretanto, a nova unidade de produção foi construída dentro das instalações da VMI Sistemas Médicos.

A VMI é uma empresa tradicional e mais moderna fabricante nacional de equipamentos por imagem, em Lagoa Santa, MG. Para que venha produzir o quanto antes os aparelhos de ressonância 
magnética da Philips, fornecedores de peças vem sendo capacitados e também há parcerias com pesquisadores da Universidade de São Paulo e Universidade Estadual de Campinas.

Como a VMI, a Philips vem adquirindo algumas das principais empresas nacionais, como a Dixtal, fabricante de monitores de beira do leito, sistema de ventilação forçada, aparelhos de anestesia, eletrocardiógrafos, possui 30 anos e é importante fornecedor de equipamentos médico-hospitalares no mercado nacional.

Também é relevante mencionar nesse contexto nacional que a internacionalização das grandes empresas se dá tanto no âmbito da produção, como vimos, quanto no âmbito comercial, dada a rede de representantes e serviços autorizados que cativa no território nacional.

É evidente que esse conjunto de atividades recentes ligadas à divisão do trabalho hegemônico configura o circuito superior vinculado aos equipamentos médicos. Diante das unicidades produtoras da globalização ${ }^{34}$, vemos que essas empresas são portadoras de uma força, cujas variáveis são produtoras das unicidades.

Determinantes no movimento das técnicas à saúde, são empresas também difusoras de uma certa informação globalizante que, vinculadas às redes financeiras, são diretamente responsáveis pela aceleração das modernizações em saúde e do território nacional.

\subsubsection{A produção nacional de equipamentos médico-hospitalares}

Tanto pela organização da produção como pelas novas necessidades baseadas na informação e no consumo, é possível observar uma dialética do território vinculada ao papel atual do trabalho intelectual como força produtiva do nosso tempo.

\footnotetext{
${ }_{34}$ "No fim do século XX, graças aos avanços da ciência, produziu-se um sistema de técnicas presidido pelas técnicas da informação, que passaram a exercer um papel de elo entre as demais, unindo-as e assegurando ao novo sistema técnico uma presença planetária” (Santos, 2000:23). Base do fenômeno da globalização, a unicidade da técnica, a convergência dos momentos e a existência de um motor único na história, representado pela mais-valia globalizada são os três fatores contemporâneos com os quais Santos explica a globalização como ápice do processo de internacionalização do mundo capitalista e as transformações recentes do espaço geográfico.
} 
Nesse sentido, a saúde enquanto criação de um território a cada dia com maior conteúdo em ciência, tecnologia e informação, apresenta-se como perspectiva privilegiada na observação dos atuais processos da urbanização. Da mesma forma, as atividades ligadas aos equipamentos médicos permitem observar como a economia urbana responde à divisão do trabalho que se instala sobre as divisões do trabalho pretéritas.

Pela observação das diferentes situações geográficas (Silveira, 1999) nas cidades de São José do Rio Preto, Ribeirão Preto e Campinas, a densa e diversificada divisão territorial do trabalho se mostra na forma dos circuitos da economia urbana.

Como Santos (1979) nos ensina reconhecer, o espaço não é homogêneo, acumula tempos e evolui de modo desigual, pois a difusão dos objetos modernos e a incidência das ações não são tampouco as mesmas em toda parte.

Desse modo, o processo de desmetropolização que vemos acontecer na região concentrada parece revelar um aporte significativo para perceber a dinâmica territorial que se dá pela produção nacional recente de equipamentos médicos, assim como as escolhas geográficas das empresas hegemônicas.

A existência das vias de transporte e de comunicação, o conteúdo técnico e científico desses lugares, a intensa organização política, expõe tais cidades ao interesse das ações públicas e privadas que envolvem a modernização das atividades de produção e consumo da saúde.

Com o intuito de aumentar a competitividade do país a partir de condições específicas oferecidas por alguns lugares, as três cidades são hoje tomadas com ênfase pelos programas de desenvolvimento da saúde, seja pelo Sistema de Parques Tecnológicos do Estado de São Paulo, seja pelas políticas federais, como veremos mais adiante.

Nesse sentido, a existência de serviços de saúde de alta complexidade médica como "referência" nesses municípios, não é um dado menor na escolha das localizações das especializações produtivas. Pelo contrário, revela que alguns subespaços se tornam mais aptos ao acolhimento das intencionalidades dos agentes. 
As condições de circulação são tão importantes quanto as condições de produção, ensina Arroyo (2006):

"Daí as pressões das empresas para a existência e a eficácia de uma rede de transportes e comunicações quando decidem estabelecer-se num lugar. As vias rápidas lhes garantem uma circulação rápida, isto é uma transformação rápida do produto em consumo, em mercadoria, em capital realizado" (Arroyo, 2006:76)

Pois é dessa maneira que a circulação diferenciada do excedente cria uma hierarquia entre os lugares. Decidida pelas empresas e pelo Estado, as atividades são redistribuídas na rede urbana, cuja hierarquia se torna plástica, pois sempre mutante em função dos interesses e estratégias dos agentes.

As vantagens que os lugares oferecem são, portanto, cada vez menos naturais e sim mais construídas, de tal modo que modernizações, técnicas e políticas, são sobrepostas às divisões do trabalho de momentos pretéritos, privilegiando algumas áreas a adquirirem maior especialização territorial produtiva.

A propósito dos novos imperativos da circulação, o espaço se mundializa. Graças ao fato do sistema técnico ser dependente do saber científico, alguns lugares são dotados de uma especificidade ainda mais nítida, compreendida pelos processos de diferenciação responsáveis por atribuir novas funções às cidades.

Esses programas são baseados nas exigências de um território fluído em sua base material e organizacional, obedientes aos mandamentos da competitividade. Desse modo, revelam como o Estado, se empenha na construção de infraestruturas, na organização do trabalho, enfim, na distribuição os recursos públicos da nação.

Vimos que a lógica da oferta de serviços responde a um modelo híbrido público e privado de saúde. Nesse contexto, onde diversas hierarquias se impõem parece aumentar a compartimentação do uso do território ${ }^{35}$, sobretudo quando o Estado alinha suas funções a um código da mercadoria.

${ }_{35} \mathrm{O}$ governo de São Paulo anunciou recentemente o incentivo fiscal para hospitais e laboratórios particulares na importação de tomógrafos, mamógrafos, ressonâncias magnéticas e ultra-sons, entre outros aparelhos de imagem, sob a condição de que o equipamento não tenha similar fabricado no Brasil (Folha de São Paulo, 12 de março de 2010). Ao invés de pagarem o ICMS na importação, realizarão exames gratuitos em pacientes do sistema único de 
o princípio da diferenciação do espaço, que nos mostra Camille Vallaux (1914), pode ser observado hoje pelo modo como os atores hegemônicos não apenas usam como, nesse movimento, recriam permanentemente as variáveis determinantes do período, isto é, a tecnociência, a informação e as finanças.

As funções modernas, aquelas que orientam a inserção da cidade na atual divisão internacional do trabalho, expressam as ações representativas do período. Contudo, são as heranças de divisões do trabalho passadas que permitem uma combinação presente, tornando complexa a coexistência e intensa a interdependência entre as atividades, as cidades, os países.

A cooperação e conflito do território usado por diferentes agentes pressupõem que não haverá no país uma única divisão territorial do trabalho, mas sim um rendilhado de atividades com diferentes condições técnicas e políticas à produção.

Sob a força de um consumo que se aprofunda, áreas diferentemente equipadas permitem a instalação de usos mais ou menos rentáveis, ensina Silveira (2004). É esse o sentido da consideração da cidade como um todo em permanente movimento, pois é, ela mesma, um conjunto solidário e contraditório de

saúde, até que chegue o valor do incentivo dado. O governo de São Paulo vem, com isso, buscando modernizar o parque de equipamentos de muitos hospitais e, ao mesmo tempo, aumentar os exames para o SUS, numa ação conjugada. Entretanto, isso se dá ao lado da realidade da diminuição de leitos públicos. Entre 2000 e 2009, os leitos públicos caíram 26\%, fato explicado, sobretudo, pela influência das ações dos planos de saúde, que prometem maiores rendimento aos hospitais, à medida que passam a preferir outros acordos diferentes daqueles com SUS. Todavia, acrescentamos àquela notícia que o anúncio dos hospitais empenhados em trocar o incentivo fiscal pelo atendimento ao SUS de dá por parte dos mesmos hospitais que, recentemente, anunciaram se unir para atrair para o Brasil um mercado internacional de turismo médico (Estado de São Paulo, 27 de agosto de 2010). Estes hospitais são filantrópicos e alguns dos mais modernos hospitais do país: Albert Einstein, Sírio Libanês, Oswaldo Cruz, Samaritano e Hospital do Coração. Sob influência de agências de planos de saúde internacionais, o país revelado um mercado em ascensão para o turismo médico. Não podemos inferir essa relação de modo mecânico ou direto, mas podemos reunir elementos que evidenciam uma lógica econômica da assistência médica no país, ao lado da socialização do dinheiro público em benefício de grandes agentes econômicos. Essa observação apenas reforça essas questões estruturais, reveladoras de um descompasso entre a tecnificação da medicina e um sistema de saúde que se pretende universal. Nesse sentido, enquanto o Tribunal de Contas reclama a subutilização dos mamógrafos no país, o governo de São Paulo se gaba do incentivo fiscal para o bem dos pacientes e o Ministério da Saúde diz que a diminuição dos leitos públicos não representa um problema em si (pois há uma tendência a que os muitos procedimentos sejam resolvidos em ambulatórios), a aceleração das modernizações no sistema de saúde revela uma lógica da economia hegemônica. Ainda nesse sentido lógico, vemos que essa realidade altamente moderna convive com realidades opacas, como o exemplo do Hospital Estadual da Restauração, no Recife (PE) que, em 2009, reclamava dos pacientes em macas, nos corredores, por falta de vagas e tudo mais. 
divisões do trabalho, onde as mais variadas atividades encontram seu lugar.

Daí que o território não é formado apenas pela ação dos grandes grupos e do grande capital, pelo contrário, compreende a todos, independente de suas forças.

"O espaço se dá ao conjunto dos homens que nele se exercem como um conjunto de virtualidades de valor desigual, cujo uso tem que ser disputado a cada instante, em função da força de cada qual." (Santos, 1996:254)

No processo de urbanização, a modernização industrial que o país conhece nos últimos 40 anos mostra que 0 aumento da população empregada foi devido à profusão, nas metrópoles, de indústrias menos modernas, com diferentes graus de capital tecnologia e organização.

Vimos que essa realidade casa-se bem ao que se apresenta como produção nacional de equipamentos médico-hospitalares. Em 2008 temos que mais de $80 \%$ das empresas têm capital de origem nacional, 58\% do total das empresas está representado pelas firmas com menos de 99 funcionários.

No período de 1998 a $2004^{36}$, a região Sudeste foi responsável por $75 \%$ do total do emprego dessa indústria, enquanto que a região Sul e Nordeste, cada uma delas, 7,2\%, a região CentroOeste, $1,4 \%$ e a Norte, $0,6 \%$. Já a participação do estado de São Paulo representa 55\%, Minas $13 \%$ e Rio de Janeiro 6,6\% do total do emprego no setor.

Essas e outras informações parecem mostrar como a produção de equipamentos médicos no país pode ser compreendida no interior dos processos da urbanização brasileira. A diversificação e densificação da divisão do trabalho nas maiores cidades evidenciam que quanto maiores e mais populosas, mais capazes são de abrigar uma extensa gama de atividades e de conter uma lista maior de profissões (Santos e Silveira, 2001).

A cada dia há um número menor de atividades e de empregos relacionados diretamente a essa produção hegemônica, e isso é mais visível nas grandes cidades do país, destaca Silveira (2004:10). Nesse sentido, conhecemos uma expansão da

36 FIPE, 2008 - "Uma agenda para a indústria de equipamentos médico-hospitalares e odontológicos". Estudo solicitado pela Secretaria de Desenvolvimento do Estado de São Paulo. 
terciarização da economia e do emprego e, com efeito, uma urbanização galopante, tanto mais concentrada quanto os capitais (Santos, 2008:55).

Em contraposição ao capital intensivo das grandes empresas, atividades não-hegemônicas, estimuladas pela expansão do consumo tanto das classes pobres como médias, surgem compensando o capital escasso através de trabalho intensivo. Sendo que são as maiores cidades que consente custos mais baixos de produção.

Enquanto crescem as demandas, o mercado adquire espessura e segmentação. Como a adaptação do meio construído à economia moderna se dá apenas pontualmente, a cidade permite abrigar naquelas áreas menos valorizadas formas de trabalho que subsistem a partir de uma variedade de combinações de possibilidades produtivas.

Nesse momento em que os lugares são caracterizados em função das diferenças de informação neles contidas, isto é, que os fluxos de informação venham hierarquizar o sistema urbano, a expansão da pobreza nas maiores cidades expressa o fenômeno da involução metropolitana, observado por Santos (1987).

Definida pela tendência do crescimento econômico metropolitano ser relativamente menor do que o das áreas mais facilmente atingidas pela modernização tecnológica e científica, a metropolização se dá também como involução metropolitana, pois ao passo em que há uma dispersão da classe média, a grande cidade irá abrigar um grande número de pobres.

Em resposta desencadeada à rigidez das novas necessidades de intercâmbio e regulação, as maiores cidades aparecem ao processo de urbanização como sítios em que há lugar para todos os níveis e tipos de capital, ao qual se agregam tantos tipos de trabalho.

A noção de trabalho e de instrumento de trabalho, nesse sentido, assevera Santos (1996) são muito importantes na explicação geográfica. E escreve:

"A cada lugar geográfico concreto corresponde, em cada momento, um conjunto de técnicas e de instrumentos de trabalho, resultado de uma combinação específica que também é historicamente determinada”. (Santos, 1996:46) 
2.1.3.i. Sobre a diversidade de divisões territoriais do trabalho

A partir de um enfoque que não se detém na anteposição de uma visão escalar do espaço, porquanto escala significa tempo, vemos que é o contexto próprio dos agentes que revela as variáveis que se integram num conjunto de vida. Santos (1996) quando ensina que a técnica autoriza um tempo empírico como escala de ação nos aponta sobre esse contexto de vida nas formas.

Ao tempo em que se torna mais complexa a geografia do mundo, a divisão do trabalho é tomada como um conceito plural (Silveira 2007). A cidade que, quanto maior e mais populosa mais capaz de abrigar diferentes formas de trabalho, expressa de modo plural as temporalidades práticas dadas pela variedade de níveis de tecnologia, capital e organização que abrigam.

Acompanhando Silveira (2007) nessa direção, a divisão do trabalho como uma noção plural evoca tal conceito renovado de escala. Entendida como escala de tempo, a ação se torna flexível em relação à diversidade dos objetos e das formas de trabalho. Em seu conjunto, a força dos diferentes agentes coexistindo revela um princípio de realidade histórica.

Ainda que as mesmas oportunidades estejam presentes, os usos das variáveis da época são diversos, conferindo aos agentes diferenças de temporalidade em seus contextos de pertencimento. Nessa direção, Cariola e Lacabana (2001) nos alertam para o fato da pobreza ser hoje ainda mais heterogênea.

Vemos que a técnica hegemônica não apenas seleciona, mas, ao passo em que se geografiza nos lugares, permite que, da mesma forma, seja selecionada. A essa altura, as demandas hegemônicas não são as únicas que determinam as racionalidades de uso do território.

Diferentemente do sistema técnico de outra época, o atual período possui a qualidade de que com alguns instrumentos de trabalho, num simples local, haja a produção de um bem ou serviço. Ainda que incapazes de dar maior valor às atividades e aos produtos, agentes não-hegemônicos garantem outros níveis de troca num mercado que é segmentado.

Nesse sentido, o efeito ampliado da quantidade de famílias mal providas que se valem da oferta e proximidade de insumos, 
mão de obra e clientes, representa uma demanda constante responsável pela multiplicação de formas de trabalho que se interconectam, diante das novas condições da produção.

Como observa Santos (1996), as técnicas contemporâneas são flexíveis, divisíveis, doces. Entretanto, vale ressaltar que para os equipamentos de saúde, os limites normativos são determinantes das reais possibilidades de produção e também de consumo desses objetos técnicos.

o crescimento simultâneo das cidades e das formas de trabalho com capitais reduzidos e tecnologias menos modernas mostra a dialética da modernização que, seletiva, cria maior complexidade dos circuitos da economia urbana.

Diante da modernização da saúde, as táticas de sobrevivência dos agentes econômicos para lidar com os eventos orientaram nossa investigação para observar os interstícios da economia urbana praticados por uma variedade de divisões territoriais do trabalho.

Nesse sentido, a atenção para a segmentação da economia urbana revela que a própria região concentrada constitui meios construídos fragmentados quanto a seus valores, onde divisões do trabalho de diferentes idades convivem de modo mais ou menos harmônico.

É assim que a região concentrada, locus de divisões 'extremas' do trabalho (Santos e Silveira, 2001:141), onde "aumentam as áreas destinadas à circulação e os movimentos internos resultam mais intensos do que no resto do país", permite nossa observação da economia urbana ligada aos equipamentos médicos.

Compreendendo-a pelas atividades em sua pluralidade de condições existência, a economia urbana em Campinas Ribeirão Preto e São José do Rio Preto revela o circuito superior marginal como a própria diversidade dos agentes abrigados nas cidades.

Identificado por um comportamento ora residual, ora emergente, $o$ circuito superior marginal vinculado aos equipamentos médicos autoriza que diferentes divisões do trabalho desempenhem papéis na produção e consumo da saúde. 
Num extremo que aproxima o circuito superior marginal do circuito inferior, encontramos atividades que apresentam comportamento residual em relação aos vetores modernos, como a manutenção de aparelhos de pressão analógicos, atividade muito procurada pelos hospitais públicos das cidades vizinhas às três cidades visitadas.

Noutro extremo, a porção marginal do circuito superior, quando funcional aos mecanismos da economia moderna, embora com menor condição em capital, tecnologia e organização, exprime-se por atividades emergentes. Num tempo em que a economia exige tantas complementaridades, vimos as manutenções autorizadas e fabricantes autônomos como expressões da inserção de atividades locais na organização vertical de grandes empresas.

À medida que Campinas, Ribeirão Preto e São José do Rio Preto respondem à ordem temporal da produção hegemônica, vemos multiplicar as atividades que ali compartilham de uma coerência espacial, desempenhando temporalidades que não coincidem puramente com a lógica hegemônica.

Daí o circuito superior marginal ser misto, como nos ensina Santos (1979). Dentro da cidade, dirá o autor:

"O princípio de unidade é dado, ao mesmo tempo, pelo mercado e pelo território, responsáveis pela unificação dos diversos segmentos característicos da vida urbana. Mercado urbano e território urbano são noções inseparáveis e realidades interdependentes, havendo, porém, submercados e subcircuitos espaciais de produção específicos, cada qual com sua racionalidade" (Santos, 1996:246).

Acontece que o atual alargamento dos contextos torna solidário o acontecer dos lugares num movimento unificado à escala do planeta. E as atividades, ainda que sejam marginais em algum aspecto técnico, de capital ou de organização, participam de mecanismos hierárquicos da produção globalizada.

$\mathrm{Na}$ medida em que o processo de urbanização responde às modernizações seletivas, impondo racionalidades em que 0 imperativo é a própria sobrevivência, as ações hegemônicas buscam condições preexistentes para maximizar sua força de influência para que se dê a entrada de novas técnicas, isto é, as inovações. 
Nesse sentido, como assevera Silveira (2007), as variáveisforça ao tornam-se rapidamente variáveis-suporte, terminam por sobrepor às divisões territoriais do trabalho local racionalidades vinculadas a divisões do trabalho cujos interesses são distantes.

Ao impregnar os objetos e ações que caracterizam nossa época e transformar o conteúdo dos lugares, a sobreposição de divisões do trabalho hegemônico sobre a materialidade preexistente torna complexos os circuitos da economia urbana, transformando o que Santos (1996) chamou do acontecer solidário dos lugares.

Definindo um processo acelerado de expansão e densificação dos elementos definidores da modernidade atual, a tecnociência, a informação e a finança inscrevem agentes locais numa dinâmica complexa que não obedece meramente à contiguidade urbana, mas se torna interdependente em nível global.

Desse modo, em função a produção das unicidades da técnica, da informação e do dinheiro, há uma ampliação do universo do circuito superior marginal quando observamos a economia urbana que se realiza na contiguidade. Como mostra Silveira:

\footnotetext{
"Não é surpreendente, então, que tais formas e nexos estejam presentes entre os pobres, nas divisões territoriais do trabalho que permitem sua sobrevivência, nas suas formas de consumo, nas relações de dependência, subordinação e verticalidade com os atores hegemônicos, mas igualmente nas relações horizontais que perfazem a sua existência.” (Silveira, 2007)
}

A cidade se revela por um movimento em que é pelo que contém como meio construído seletivamente valorizado que desperta o interesse de agentes hegemônicos. Observaremos adiante como as atividades de manutenção de equipamentos médicos nascidas nos lugares se tornam condições de alargamento das ações do próprio circuito superior puro.

Nesse sentido, os nexos aos quais estão ligadas as atividades locais se ampliam. A interdependência do trabalho hegemônico e não-hegemônico dilata a escala de ação dos agentes locais, tornando mais densas as relações entre a cidade, a formação socioespacial e o mundo.

Outrossim, a produção de escassez e pobreza permite que firmas menores subsistam em porções menos valorizadas da cidade 
que, com efeito, revelam modos de resistência inerentes ao próprio processo de oligopolização da economia.

Aliás, a superposição de divisões territoriais do trabalho de diferentes alcances escalares e velocidades mostra uma economia plural, como insiste Zaoual (2006:66) quando diz que o paradigma econômico e tecnicista que assegura as tendências uniformizantes mostra-se míope em relação à diversidade e à pluralidade da condição humana.

Os diferentes tempos e formas de uso do território expressam a coexistência de mercados desiguais e segmentados. A compreensão da sobrevivência de atividades menos capitalizadas e tecnificadas no tecido urbano nos leva à consideração da materialidade e o movimento da sociedade de forma indissociável.

Santos (1994:123) nos lembra que "a marcha do capitalismo é, também, a marcha para a socialização capitalista, graças à acentuação da divisão do trabalho e à necessidade, igualmente crescente, de coordenação, a cooperação é a outra face da divisão do trabalho".

Neste sentido, a cidade, apesar de fragmentada socioespacialmente, constitui um fator de socialização das forças produtivas, enquanto a urbanização reforça a socialização da produção. E nos países subdesenvolvidos, são as cidades maiores que aceleram este processo.

Daí a importância do que Santos (1994:127) ensina quando distingue do ponto de vista analítico uma economia política da urbanização e uma economia política da cidade, e enfatiza o processo de urbanização como fenômeno não apenas social, político ou econômico, mas também espacial.

\subsection{3.ii. A contiguidade das cidades para as diferentes intencionalidades}

Diante da proposta de perseguir os comportamentos dos agentes da economia urbana vinculados ao sistema produtivo dos equipamentos médicos, a espessura da região concentrada mostrounos de que forma particular o território se torna imperativo a uma economia para a saúde.

A estrutura técnica e de seu arranjo em cada situação geográfica definida nas cidades de Campinas, Ribeirão Preto e 
São José do Rio Preto, mostram como as atividades à saúde encontram nesses lugares fatores apropriados para a temporalidade prática da economia da saúde moderna.

As instituições públicas e privadas abrigadas nessas cidades, como as universidades públicas, os hospitais e outros serviços de saúde de referência apontam para o interesse se inserem no desenvolvimento dos sistemas de objetos e ações à saúde no país.

Da mesma forma, a concentração geográfica dessas instituições anuncia de que modo a esfera da saúde participa da política científica e tecnológica do país, assim como revela o papel das cidades de São José do Rio Preto, Ribeirão Preto e Campinas na divisão territorial do trabalho ligada a essa medicina moderna.

A indústria de equipamentos médico-hospitalares caracterizase por um forte conteúdo científico interdisciplinar, e como já mencionamos depende intensamente de desenvolvimentos realizados em outras disciplinas científicas e outras indústrias.

"A aplicação da ressonância magnética na medicina dependeu de avanços dos físicos no estudo da estrutura do átomo, a ultrasonografia foi filha da guerra submarina, a tomografia computadorizada foi consequência de avanços na computação e na matemática, o aparelho de litotripsia surgiu a partir de descobertas casuais da indústria aeronáutica" (Albuquerque e Cassiolato, 2002:135)

Ainda que a produção nacional não possua esse nível de inovação, o padrão tecnológico demandado por esse sistema produtivo vem caracterizar a força de influência de importantes instituições de pesquisa acadêmica existentes nessas cidades e regiões, diante da criação de oportunidade ao surgimento das atividades modernas.

Nas situações geográficas dessas cidades, a produção nacional de equipamentos médicos com maior ou menor complexidade tecnológica mostra a dependência significativa de instituições de formação técnica e superior na constituição das oportunidades de trabalho nessa área.

Aliás, vimos que as empresas produtoras de bens e serviços existentes nas três cidades nasceram dessa combinação de fatores. Isto é, o fato de terem sido funcionários numa outra empresa do setor, ou por já terem trabalhado no serviço de 
saúde, ou ainda porque contam com uma densidade tecno-científica nas cidades, são todos fatores que permitiram o nascimento de empresas nessas cidades.

Já mencionamos que a inovação na indústria de equipamentos médico-hospitalares se dá pela dependência de pesquisas realizadas na prática clínica. Nesse sentido, para o aperfeiçoamento das tecnologias médicas, a contribuição científica do exercício médico no interior do circuito produtivo não pode ser minorada.

Nessas cidades, apesar do crescimento dos estabelecimentos de saúde privados, as instituições de tradição médica são de natureza pública, como os hospitais universitários de Ribeirão Preto e Campinas.

Ramires (2007:177) nos alerta para a localização dos hospitais universitários na região concentrada ao enfatizar que estes são parcela da produção de conhecimento na área da saúde no país. Atualmente, os hospitais públicos de ensino têm participado da pesquisa em saúde. No país, estes são historicamente Locus privilegiado dos cuidados médicos e, hoje, são também local privilegiado da pesquisa em saúde.

Argumentos para uma política de ciência, tecnologia e inovação em saúde articulam a idéia de que os hospitais de ensino brasileiro vêm passando por problemas desde os anos 1990, sob o risco de perder sua característica histórica na vanguarda da pesquisa clínica e avaliação tecnológica (Guimarães, 2004).

Sob o reconhecimento da atual dependência dos serviços de saúde das tecnologias importadas, a atual política nacional de ciência, tecnologia e inovação em saúde ressalta esses hospitais de ensino do país e, nesse sentido, atribui importância a essas cidades.

A propósito, o apoio à produção científica no país esteve tradicionalmente vinculado a instituições públicas de pesquisa, principalmente acadêmicas, ainda que atualmente haja uma tendência à participação da iniciativa privada no financiamento e execução da pesquisa e desenvolvimento no Brasil.

Trataremos dessa questão no capítulo seguinte quando dermos mais atenção aos programas políticos em específico. Por ora, vale dizer que aprimorar medicinas depende da prática clínica e, 
nesse sentido, o incremento tecnológico não se trata apenas de uma proximidade da indústria a médicos empenhados em testes, mas demonstra o papel de médicos-cientistas, ou seja, a prática médica na própria pesquisa acadêmica pública.

Pelo estímulo à interação universidade-empresa, ou mesmo outras formas mais abrangentes de investimento privado para a inovação, a saúde se torna tema forte no interior dos grandes debates nacionais, trazendo a tona as especializações territoriais em algumas cidades do Estado de São Paulo.

De qualquer forma, a desarticulação da capacidade científica nacional com a indústria nacional de equipamentos médicos é um dado da formação socioespacial, enquanto o estímulo à interação das instituições de pesquisa com os sistemas produtivos é parte da tendência recente da política científica e tecnológica do país.

Essas três cidades vão, então, mostrando sua relevância para os programas políticos atuais pelo conteúdo técnico-científico em saúde que a constituem. Também, um olhar para a formação médica não será aqui um acaso. Obedecendo a concentração da produção de bens e de serviços mais "nobres" nessas cidades, as qualificações renovadas e novas profissões se tornam indiscutíveis demandas nas cidades.

Os novos cursos de medicina, enfermagem, nutrição, fisioterapia, educação física, além dos cursos técnicos específicos para os equipamentos - seja para atividades de fabricação ou mesmo para os serviços de saúde, como inspeção radiológica - mostram não apenas essa densidade tecnocientífica apropriada à produção moderna, como revelam o denso mercado de produtos médicos.

Essas cidades acolhem maior contingente de classes médias e veem crescer o número de letrados. A difusão geográfica do ensino de medicina e áreas afins, assim como os mais recentes cursos técnicos radiológicos, por exemplo, respondem a essa racionalidade própria do lugar.

Como puderam verificar Santos e Silveira (2001):

"Há, certamente, seletividade na expansão desse meio técnico científico informacional, com reforço de algumas regiões e o enfraquecimento relativo de outras. A divisão social e territorial 
do trabalho amplia-se e torna-se mais complexa. Em todo caso, a demanda por qualificações específicas aumenta em todas as regiões, enquanto a oferta parece acompanhar as especializações produtivas dos lugares." (Santos e Silveira, 2000:34)

De modo geral, vemos que o modelo capitalista da globalização está para além do domínio industrial. As modernizações impõem-se de forma renovada às esferas públicas, em que a organização e o conteúdo do ensino, as profissionalizações, assim por diante, passam a responder às novas demandas da cientifização do trabalho e informatização do território.

A incorporação de novas tecnologias na saúde tem exigido novas qualificações para operação dos aparelhos. Nesse sentido, sabemos que $20 \%$ a $40 \%$ do parque de equipamentos no país está inoperante, por aquisições inadequadas, qualidade insatisfatória e pelo uso indevido dos equipamentos (ABDI, 2008).

E, para mudar a complexidade tecnológica da produção nacional e beneficiar a condição do parque nacional, os programas de modernização têm considerado a importância do desenvolvimento de recursos humanos.

Os múltiplos campos correlatos de saber terapêutico concentrados no Sul e Sudeste do país (Santos e Silveira, 2000), bem como a formação médica tradicional, permitem refletir sobre os novos conteúdos do território atrelados às modernizações dos serviços de saúde, e aos apelos profissionais condicionados por uma geografia da saúde.

Como em tais cidades se aglutina uma demanda de serviços de diagnósticos e tratamentos, vemos a busca de atualização dos saberes técnicos e científicos relacionados com os equipamentos médicos, ao mesmo tempo em que há uma demanda por saúde moderna amplia um mercado ligado às qualificações.

Ainda, sabemos que os médicos se concentram onde estão as novas técnicas e, com isso, mostram a força de influência do "mercado de trabalho" na instalação do médico. o crescimento das clínicas privadas mostra como respondem os lugares às novas demandas de um mercado de saúde.

No gráfico a seguir, nota-se que o aumento do número de estabelecimentos privados é enorme. 
GRAFICO 6 - Número de estabelecimentos de saúde por tipo de prestador Brasil, 2005 - 2010

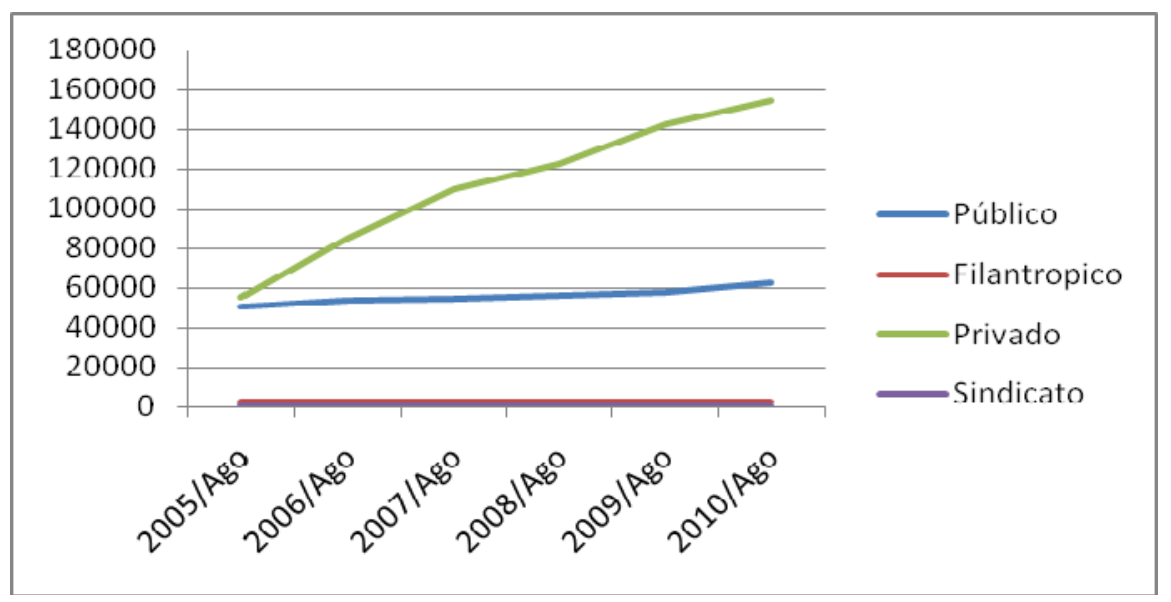

Fonte: Ministério da Saúde, DATASUS - Cadastro Nacional dos Estabelecimentos de Saúde do Brasil

A concentração de diferentes estabelecimentos públicos e privados exibe parte dessa lógica vinculada aos equipamentos médicos, assim como uma economia urbana para a saúde. Desse modo, revela o papel dessas cidades na divisão territorial do trabalho mais moderna da nação.

TABELA 11 - Estabelecimentos de saúde por tipo de prestador - Campinas, Ribeirão Preto e São José do Rio Preto, 2005 - 2010

\begin{tabular}{l|r|r|r|r|r|r}
\hline \hline & \multicolumn{2}{|c|}{ Publico } & \multicolumn{2}{c|}{ Privado } & \multicolumn{2}{c}{ Filantrópico } \\
\hline & 2005 & 2010 & 2005 & 2010 & 2005 & 2010 \\
\hline Campinas & 92 & 116 & 206 & 1704 & 16 & 18 \\
\hline Ribeirão Preto & 70 & 127 & 184 & 1199 & 6 & 8 \\
\hline São José do Rio Preto & 55 & 66 & 251 & 596 & 9 & 11 \\
\hline \hline
\end{tabular}

Fonte: Ministério da Saúde, DATASUS - Cadastro Nacional de Estabelecimentos de Saúde do Brasil

Nesse sentido, as intencionalidades ocultas das técnicas que se implantam nas nações e nos lugares nos permitem captar a pluralidade de divisões territoriais do trabalho e a convivência da diferença que a cidade autoriza.

Se por um lado há uma economia espontânea ligada às demandas da saúde e por saúde, por outro, esses lugares aparecem como oportunidades para que vetores específicos sejam portadores de interesses particulares no processo de modernização dos serviços de saúde e do sistema produtivo nessas cidades.

A partir da possibilidade de aproveitamento de uma racionalidade situada (Zaoual, 2006), a saúde, enquanto 
estratégia de crescimento econômico do Brasil, compreende essas cidades no programa de desenvolvimento produtivo do país, associando, com isso, a intenção de trazer melhorias à saúde.

Assim como a ideologia do consumo e do crescimento econômico, - planejamento também se revela um instrumento político na adaptação dos espaços nacionais à economia internacional (Santos, 1996). Veremos como essas cidades respondem aos interesses produtivos de uma saúde moderna no país a partir de alguns programas estaduais e federais.

Nesse sentido, sabemos que, hoje, as potencialidades dos lugares são suscetíveis de avaliação prévia. Esse conhecimento fundamental na escolha das localizações mostra não apenas a cobiça cientificizada a que os lugares estão sujeitos, mas também o papel condicionante que desempenham na dinâmica da competitividade global.

Refletindo sobre o papel das normas no processo de funcionalização da totalidade, isto é, o espaço geográfico, Silveira (2004) nos ensina ao dizer:

"Existe uma totalidade prévia, um mundo construído. É o arranjo de objetos que, ao mesmo tempo em que é transformado, obriga os vetores a uma adaptação. A esse fenômeno poderíamos chamar de escala de império, um verdadeiro limite normativo, porque material e organizacional, ao processo de totalização. É a extensão da ação de fato funcionalizada (Silveira, 2004:91)

A introdução de fatores de complexidade a partir dos acréscimos de ciência, tecnologia e informação amplia os limites e também os dinamismos, enquanto a superposição de divisões do trabalho mais modernas nos lugares convida a todos os agentes a obediência de tempos acelerados.

0 apetite das formas e nexos integrados à economia mundial imprime um ritmo das normas, cuja aceleração, muitos não conseguem acompanhar. Portanto, a subordinação que encontramos de um grande número de agentes nessas cidades, submetidos aos imperativos de uma economia moderna, não pôde ser medida apenas pela distância tecnológica e de capital entre as firmas hegemônicas e não-hegemônicas.

A maneira pela qual o Estado se torna mediador das variáveis determinantes do período diante de uma aceleração das 
tecnologias médicas se revelou um caminho de observação das economias urbanas ligadas à saúde e a dinâmica vinculada aos equipamentos médicos.

A natureza dos objetos informacionais, a racionalidade vertical que é imposta, o modo de integração da produção nacional num circuito de escala global, convidou-nos à reflexão sobre o papel do Estado na combinação dos interesses do mercado e da nação.

Sob a perspectiva das oportunidades para a sucessão de modernizações a partir de políticas públicas, convém lembrar que o próprio sistema de saúde constitui essa norma do território, quer queira, quer não, facilitadora da concentração das benesses da medicina moderna.

\subsection{O papel dos hospitais na economia urbana}

A economia urbana para a saúde no período da globalização deve muito à dinâmica promovida pela centralidade que desempenha o hospital no sistema de saúde do país. Nesse sentido, o peso relativo do hospital anuncia uma particularidade das cidades que o abrigam.

As conexões geográficas (Souza, 1992) que se estabelecem nesse contexto, pois, configuram um sistema urbano, cujos elementos se referem às relações complementares, e hierárquicas, em virtude das demandas por saúde, bem como das demandas do próprio serviço de saúde.

A moderna tecnificação da saúde testemunha não apenas o fluxo de pacientes que, privados de muitos serviços em seus lugares migram por acesso à saúde, mas também um fluxo produtivo, sobre o qual o hospital exerce um poder centrípeto.

Vemos a operação hierárquica do sistema único de saúde, que conduz algumas cidades à referência em serviços de saúde de uma abrangência regional e até nacional, como é o caso de algumas especialidades médicas. Entretanto, quanto mais modernos se tornam os estabelecimentos e, com efeito, os serviços, maior é a intensidade das trocas, isto é, a circulação não apenas de pessoas, mas de objetos e mensagens. 
Portadores de uma força na rede urbana, os hospitais são expressão de uma diferenciação geográfica da oferta de serviços de saúde na formação socioespacial brasileira, oferta que devemos observar tanto pela esfera pública como pela esfera privada.

Da mesma forma, os hospitais imprimem uma combinação de caráter geográfico, como define A. Cholley (1964), no entanto, como assevera Arroyo (2206:77), trata-se de uma combinação específica referida a um determinado produto ou atividade produtiva.

Os hospitais, portanto, são responsáveis por assegurar elementos importantes na constituição de uma produtividade espacial (Santos, 1979) para a economia da saúde. Compreendidos em seus contextos, os hospitais motivam a coexistência de diferentes divisões territoriais do trabalho, autorizadas por uma variedade de demandas a serem satisfeitas.

Desse modo, ao atermos a observação sobre os equipamentos médicos, nossa interpretação das hierarquias urbanas busca compreender as existências materiais sem que estas estejam dissociadas do trabalho vivo que anima os objetos. A dinâmica modernizadora da medicina e, com efeito, dos hospitais, evidencia o reforço às funções hospitalares e mostra também um uso do território que não é apenas hierárquico, mas também desigual.

Pela liberdade dos hospitais privados, dos filantrópicos e, ainda, pelo empenho público de concentrar alguns serviços de excelência no Estado de São Paulo, podemos dizer que há uma compartimentação territorial do acesso à saúde, pelo sistemismo fragmentado em função de interesses de mercado ${ }^{37}$.

Cidades em que a capacidade de atendimento dos serviços de saúde, referência para suas regiões, está em grande parte medida

\footnotetext{
37 No Brasil, 80\% da população é dependente do sistema único de saúde, isso porque o restante conta com planos de saúde - o que não quer dizer que esses mesmos $20 \%$ não se utilizem de alguns serviços médicos públicos. Entre 2000 e 2009, a redução de leitos públicos do sistema único de saúde foi de 26\%, mas o Ministério da Saúde não declara ser este um problema, mas um efeito da própria evolução médica, em que algumas doenças hoje deixam de depender da hospitalização. Mas quando as questões se revelam no âmbito do mercado, outros fatores entram em cena. Os hospitais privados conveniados têm preferido acordos com as empresas de planos de saúde, onde o pagamento por um procedimento médico é maior do que o realizado pelo SUS, e aumentam assim suas receitas, importantes também para modernizarem a oferta particular de seus serviços.
} 
pelo nível de modernização, mostram também a lógica geográfica da oferta e do acesso a qual os serviços estão submetidos.

A modernização dos hospitais e serviços de saúde torna densa a dinâmica em que estão envolvidas as demandas relacionadas aos equipamentos médico-hospitalares. Por vezes essa dinâmica econômica resulta em certa integração regional de atividades.

Sabemos já que quanto mais mercantilizado o universo da saúde, maior a intensidade das trocas, pois pela natureza dos sistemas de objetos e ações contemporâneos, os circuitos espaciais de produção não se completam nos lugares.

A modernização, nesse sentido, representa um crescimento das demandas por equipamentos e atesta o aumento da circulação de objetos, normas de manipulação dos mesmos, orientações para seus consertos, regras para suas práticas, informações de toda ordem, fiscalizações e assim por diante.

Se por um lado as funções hospitalares representam crescentes demandas por conteúdos técnico-científicos e informacionais em saúde, é cada vez mais densa a divisão do trabalho em que a obtenção de seus insumos está envolvida.

o Brasil é grande consumidor de tecnologias médicas modernas e, relativamente, pouco produtor. Embora tenha aumentado em todos os subsetores ${ }^{38}$ a exportação nacional, a balança comercial revela que, entre 2000 e 2006, há um aumento da importação ${ }^{39}$, menos de aparelhos odontológicos.

A indústria brasileira responde por mais de $50 \%$ do mercado interno total de equipamentos médicos no país, sendo o restante suprido pelas importações. A necessidade de importação de equipamentos médico-hospitalares é, ela mesma, um imperativo à aceleração da substituição da divisão do trabalho por outra mais moderna. Pois, o aumento dos fluxos, nesse sentido, representa também o acréscimo de exigências, às quais estarão submetidos não só alguns, mas todos outros agentes.

\footnotetext{
38 De acordo com essa classificação emprestada da Associação Brasileira de Desenvolvimento Industrial, os subsetores são Odontologia, Laboratório, Radiologia (diagnóstico por imagem), Equipamentos Médico-Hospitalares, Implantes e Materiais de consumo.

39 A balança comercial entre 2000 e 2006, de acordo com a ABDI, teve um aumento do déficit, que passou de US $\$ 1.093 .857$ para US $\$ 1.590 .862$.
} 
A realidade de Campinas, Ribeirão Preto e São José do Rio Preto como cidades em que é significativa a produção científica e tecnológica, anuncia certa tendência a acumular modernizações tecnológicas de equipamentos médicos.

Mas, por mais que a região permita uma integração econômica, dada pela cooperação do trabalho existente na contiguidade, os mecanismos de racionalização das atividades imprimem a subordinação de alguns agentes.

A chegada de sempre mais nova divisão do trabalho nessas cidades autoriza maior complexidade da economia urbana e desvela o permanente movimento que é o uso do território como um sistema de vasos comunicantes, em que podemos observar ambos os circuitos, inferior e superior e sua porção marginal.

Nesse sentido, a partir dos objetos novos, o reforço às funções hospitalares para a promoção dos cuidados à saúde termina por aglutinar nessas localidades um enorme poder de compra, válido pelo volume, diversidade e qualidade dos bens e serviços de que demandam. Podemos acrescentar que não apenas o sistema público, mas também a iniciativa privada tem tido participação significativa no aumento da demanda para a indústria de equipamentos médico-hospitalares.

A produção nacional tem importante papel no fornecimento de equipamentos médico-hospitalares no mercado interno, entretanto, entre 2007 e 2009, houve um decréscimo dos compradores públicos e aumento das proporções de compras por estabelecimentos privados.

TABELA 12 - Tipo de compradores de equipamentos médico-hospitalares no país, 2007 - 2009

\begin{tabular}{l|r|r}
\hline Compradores & $\mathbf{2 0 0 7}$ & $\mathbf{2 0 0 9}$ \\
\hline Publico & $44 \%$ & $21,6 \%$ \\
\hline Privado & $48 \%$ & $68,6 \%$ \\
\hline Exportação & $8 \%$ & $8,8 \%$ \\
\hline Outros & - & $1 \%$ \\
\hline
\end{tabular}

Fonte: ABIMO - 2008 e 2010

o território é, ele próprio, uma oferta para a produção e o consumo de saúde. Desse modo, os diferentes circuitos da economia urbana se mostram quando se observa o conjunto dessas 
atividades num dado contexto e a população que, em função de um mercado segmentado, se liga a elas para trabalhar e para consumir.

Compreender a dinâmica da produção nacional de equipamentos médicos, a partir dos comportamentos expressos enquanto fornecedores de insumos hospitalares, permite observar o modo como as empresas estão integradas nas suas respectivas economias urbanas.

As diferentes divisões territoriais do trabalho autorizam, pois, que atividades usem de forma diferenciada a rede urbana. A partir de onde estão abrigadas, as atividades hoje estabelecem circuitos de produção mais largos. Como ensina Silveira (2007)

"Cada uma [empresas] tem uma forma particular de combinar os objetos que necessita para o exercício de sua ação e uma forma particular de organizar as ações para fazer funcionar tais objetos. Se trata de pontos e áreas que a empresa seleciona e que conformam sua base material de existência. É sua própria divisão do trabalho: uma verdadeira topologia, tantas vezes confundida com as necessidades da nação." (Silveira 2007:15)

Nesse sentido, há aquelas atividades que estão na região, tomando proveito das infraestruturas, mão de obra, por uma condição técnica e de capital tal que permite vantagem esperada à sua rentabilidade. Mas, há aquelas empresas que dali não podem sair, pois não é uma opção, mas uma condição, da qual tomam proveito.

Ao meditarmos no papel das normas atuais, observamos a capacidade produtiva nacional, expondo-a as contemporâneas exigências técnicas, organizacionais e políticas. Entretanto, antes dessa abordagem dirigida, perguntamo-nos por que meios a indústria nacional põe em circulação seus produtos, já que seus mercados nem sempre coincidem com seus locais de fabricação.

\subsubsection{Algumas implicações geográficas}

Como dinamizadores de uma economia urbana para a saúde, os hospitais apresentam alguns complicadores à compra direta da produção nacional, por representarem alta e média complexidade tecnológica e por serem compradores de grandes volumes, quando os produtos são de complexidade mais baixa. 
A estrutura produtiva nacional de equipamentos médicos possui um relativo limite tecnológico e, por serem pequenas empresas, por produzirem em pequenas quantidades, propomos observar algumas nuanças.

Muitos produtores repassam suas mercadorias a distribuidores como forma de aumentar seu alcance de mercado. Esses pequenos fabricantes estão localizados nas regiões onde há os serviços mais modernos do país, sendo que a demanda por produtos médicos é difundida no território nacional.

Aqueles hospitais mais modernos, situados nas regiões mais ricas do país, são grandes potencias de consumo produtivo. Mas grande parte de seus insumos e equipamentos têm origem multinacional ou de empresas maiores, capazes de maiores escalas de produção.

Nesse sentido, o acréscimo compatível a escala da compra hospitalar é obtido pelas atividades de grandes distribuidores, ou mesmo representantes de empresas maiores que, assim, tornamse fornecedores dos hospitais.

Já aqueles serviços com certa complexidade médica, previstos pelo sistema único de saúde, estão em muitos lugares, isto é nas maiores cidades e capitais do país. Esses sim encontram nos produtos nacionais uma oportunidade, o que torna as atividades de distribuição também uma oportunidade de encontrar mercados, ainda que difusos no território nacional.

Nesse sentido, aquelas empresas fabricantes com maior nível de capital e organização distribuem seus próprios produtos, mas aquelas com menores capacidades de alcances largos, dependem ainda mais dos seus mercados próximos e de distribuidores.

A produção nacional vende seus produtos a muitos outros serviços de saúde do país, não apenas aos hospitais. Embora a oferta dos serviços seja desigual, o sistema único de saúde garante a existência em todos os municípios de algum serviço que é no mínimo de atenção básica.

Como serviços que usam obrigatoriamente muitos tipos e níveis de produtos médicos, ainda que básicos, há uma inumerável demanda por agulhas, termômetros, seringas, soros, e muitos outros usados em muitos contextos. 
Já vimos mostrando que as empresas nacionais são, em sua maioria, micro e pequenas e estão concentradas naquelas regiões em que é possível o acesso às vias de transporte e comunicação. Também, que os conteúdos técnico-científicos desses lugares a formação técnica ou superior adequada ao ramo dos equipamentos médicos sustentam algumas razões de suas localizações.

De qualquer modo, são meandros os caminhos que a produção nacional percorre para encontrar seus mercados de destino. E é a própria densidade e diversidade de divisões territoriais do trabalho que autoriza diferentes circuitos espaciais da produção de equipamentos médicos no interior do país.

Propostos por Santos (1985) para compreender o comportamento do espaço indivisível diante da repartição das atividades entre lugares, os circuitos espaciais de produção procuram captar o movimento que o processo de acumulação realiza, envolvendo diversas empresas e ramos e, também, diversos níveis, local, nacional, internacional, como ensina Arroyo (2006:76).

Captar essa contemporânea intensificação das relações entre pessoas e lugares em seu permanente movimento, como assevera a autora (Arroyo, 2006), pressupõe o fluxo material e nãomaterial, como ordens, informações, capital de modo indissociável.

Podemos afirmar que a variedade incalculável de objetos médicos, o crescimento dos consumos de bens e serviços à saúde, e as outras demandas inevitáveis à prestação dos serviços, permite a existência de pequenos mercados compatíveis com a produção nacional.

De acordo com nossas pesquisas em Campinas, Ribeirão Preto e São José do Rio Preto, há alguns processos específicos e gerais nas cidades, ambos relacionados com o imperativo contemporâneo da circulação e as complementaridades do trabalho.

o fato da produção nacional ter enorme dificuldade de que os hospitais, principais compradores, sejam seus consumidores finais foi um dado extensamente verificado pelos diferentes agentes, isto é, produtores, distribuidores, representantes, compradores hospitalares, gestores públicos.

Porém, o território usado por uma diversidade de condições particulares compartilhadas, diante das incompletudes que fazem 
com que o processo de totalização não cesse, revela como as pequenas empresas ocupam interstícios da economia urbana e se ocupam de um trabalho que se torna indispensável ao conjunto da sociedade.

Por meio de distribuidores, representantes, vendedores autônomos, por meio eletrônico, assim como outras formas de trabalho, os produtores nacionais de equipamentos médicos usam o território também como um mercado segmentado, buscando, com isso, sobreviver e distribuir seus bens de saúde.

Quando nos atemos exclusivamente aos fabricantes - e não representantes - desses equipamentos, como demonstraram os dados das cidades que os abrigam, conferimos em Ribeirão Preto um número maior de produtores relativamente a Campinas e São José do Rio Preto, apesar de ter quase a metade da população de Campinas.

Aliás, dentre as cidades que produzem equipamentos médicos no estado de São Paulo, Ribeirão Preto aparece como tendo as empresas com maior média de idade, 9,3 anos, assim como a maior media de empregados. Ainda, as três cidades mostraram apresentar o maior nível de escolaridade dos funcionários das empresas fabricantes, com nível superior completo, assim como Presidente Prudente.

Das 74 cidades que possuem indústrias de equipamentos médicos hospitalares no Estado de São Paulo, apenas 12 concentram as 21 maiores empresas. Dessas, 7 estão registradas em São Paulo, 2 em Ribeirão Preto e São José do Rio Preto.

As maiores empresas produtoras de equipamentos médicos nacionais estão sediadas tanto na Região Metropolitana de São Paulo $^{40}$, como K Takaoka em São Bernardo do Campo, quanto em algumas cidades do interior ${ }^{41}$ do estado, como Dental Morelli em

\footnotetext{
${ }^{40}$ Nascida na década de 1960 , a Takaoka oferece hoje mais de 400 produtos entre aparelhos de anestesia, vaporizadores, respiradores para terapia intensiva, equipamentos de monitorização e oxigenioterapia, É uma importante empresa para os serviços de saúde, também exportadora para muitos países.

${ }_{41}$ A Braile nascida na década de 1960, fabrica produtos Cardiovasculares (filtro de sangue artéria, sistema de profusão intraperitoneal, filtro de recirculação, oxigenador de membrana, reservatório venoso, tubos de circulação extracorporal, cânulas, hemoconcentrador); Endovasculares (cateter, mola de embulização, endopóteses auto-expansivas); Eletromecânicos (máquinas de circulação, termômetro clínico digital, misturador de gases, transdutor de pressão descartável, monitor de pressão, aquecedor de sangue, sensor de temperatura, monitor de vácuo).
} 
Sorocaba, Braile Biomédica em São José do Rio Preto, Gnatus em Ribeirão Preto, Baumer em Mogi Mirim.

As cidades, então, possuem um conjunto de empresas de diferentes no porte, também com uma diversidade de objetos fabricados, em condições que revelam certa consolidação do sistema produtivo na região. Verificamos que a maneira mais comum de comercializar a produção dessas empresas é por meio de agentes distribuidores. Dentro desse sistema, tal atividade aparece como a complementaridade que permite aumentar o alcance do trabalho da pequena empresa.

Os distribuidores que mencionamos antes podem ser parceiros dos fabricantes, quer dizer, revelam um destino certo até o consumidor final, que pode ser um cliente antigo. Mas ainda há distribuidores mais autônomos, são eles próprios um tipo de estoque para distribuidores menores ou lojas em outras cidades. Nesse caso último, falamos de equipamentos pequenos, às vezes de uso pessoal, também alguns descartáveis, como agulhas entre outros. Aqui vale ressaltar algumas diferenças entre os produtos.

De modo geral, podemos dizer que quanto maior a complexidade tecnológica da mercadoria, mais direto é seu caminho até o cliente, menor é a existência de estoques e, ainda, mais controladas são suas peças. Isso porque seus representantes não possuem liberdade sobre as peças dos fabricantes.

Quanto menor o tempo de vida da mercadoria, como agulhas, seringas, mais parece haveria articulação entre diferentes agentes que repassam mercadorias, ocupando-se de tarefas em diferentes frações do território. Ainda que não seja possível generalizar, parece um dado da especificidade do circuito espacial de produção dos equipamentos médicos.

Considerando um espectro de situações, os distribuidores se abastecem direto com os fabricantes, tendo seus próprios

A Baumer, também da década de 1960, fabrica aparelhos Ortopédicos (enxerto ósseo, próteses articuláveis, fixação intramedular, fixação interna de coluna vertebral); Hospitalares (esterilização e controle de infecções, produtos e acessórios para centros cirúrgicos, recuperação, transporte e apoio de paciente); Castanho (secadoras, mobiliário para lavanderias, lavadoras de roupas hospitalares).

As outras duas, Gnatus e Dental Morelli são empresas fabricantes de produtos odontológicos, também antigas. Não nos acupamos das empresas fabricantes de produtos odontológicos na pesquisa, apesar disso revelar alguns problemas com dados, os quais já apresentamos na introdução e ao longo da discussão. 
clientes, ou ainda distribuidores que são representantes de vendas dos respectivos produtores de diferentes mercadorias.

Pois é assim que chega aos diferentes lugares do país uma produção que é concentrada em algumas regiões. Seus consumidores são na grande maioria serviços privados, também, serviços públicos de diferentes cidades no sistema urbano. Tais topologias aparecerem como estratégias individuais de comercialização de cada produção.

Como ensina Arroyo (2006):

"O circuito espacial permite agregar a topologia de várias empresas em um mesmo movimento; mas ao mesmo tempo, permite captar uma rede de relações que se dão ao longo do processo produtivo, atingindo uma topografia que abrange uma multiplicidade de lugares e atores." (Arroyo, 2006:79)

É válido mencionar que, de modo geral, os fabricantes nacionais dependem de insumos fornecidos em grande maioria pela Região Metropolitana de São Paulo. Apesar de que pequenas oficinas de peças metálicas e outros insumos de base fazem parte de uma complementaridade que se integra na própria cidade.

0 que não podemos estender aos componentes eletrônicos, cuja oferta é predominante na metrópole de São Paulo. As maiores empresas produtoras de equipamentos médico-hospitalares dependem igualmente de insumos eletrônicos, mas importam peças diretamente, enquanto as menores se utilizam dos importadores.

Entretanto, atualmente tem havido 0 interesse em criar padrões de qualidade à produção daqueles agentes forncedores de insumos para os fabricantes de equipamentos médicos, garantindo, com isso, maior qualidade produtiva nacional num contexto globalizado.

Nas cidades de Campinas e São José do Rio Preto, como o número de fabricantes é proporcionalmente menor, observamos uma multiplicidade de outras formas de trabalho praticadas pelas empresas. Nesse sentido, a produção nacional serve aos hospitais e outros serviços de saúde, não apenas pela fabricação, mas como representantes de empresas maiores nacionais ou estrangeiras. 
Ao ocupar um mercado existente para a saúde nas regiões, as atividades participam da topologia de outras ${ }^{42}$ empresas, assim como realizam sua própria topologia, ampliando as escalas das ações. De alcances espaciais variados, portanto, diferentes formas de realização econômica, mostram a interdependência das frações do território e do trabalho.

\subsection{1.i A economia urbana em Campinas Ribeirão Preto e São José do Rio Preto}

A economia urbana dessas cidades revelou tipos muito particulares de fabricação. Em Campinas, podemos dizer que a natureza técnica e científica das condições da região permite a existência de pequenos fabricantes que fazem inovação, desenvolvendo produtos novos em proveito de um denso mercado da saúde na região e demandas longínquas no território nacional.

Entretanto, há uma diversidade de empresas exercendo não apenas fabricação, mas o comércio ligado a uma variedade de outras empresas, nacionais ou estrangeiras; e ainda serviços de manutenção, sendo ou não representantes, de muitas ou apenas uma marca.

Isso quer dizer que há empresas que além de fabricantes, são também representantes de vendas de outras empresas, assim como prestadores de serviços, autônomos ou como assistência autorizada. De qualquer modo, as combinações são muitas, mas as restrições se apresentam para representação de empresas-mãe concorrentes.

Como as empresas-mãe normalmente definem a área geográfica de atuação da representante, essa última tem algumas vezes funcionários ou vendedores autônomos que se distribuem nessa área. Existe a ação da empresa-mãe e da empresa-filha, como se houvesse uma desagregação da empresa para que os equipamentos cheguem aos diferentes lugares do território nacional.

\footnotetext{
${ }^{42}$ Em Campinas, a Biocam é uma empresa nascida em 1999, cujo dono era antes funcionário da Intermed - importante empresa nacional - e fundou sua própria empresa em Campinas como distribuidor Intermed. Ao longo dos anos a empresa passou a distribuir produtos de outras importantes empresas nacionais, como a Fanem, Prolife, e a Stryker do Brasil. Em 2006 decidiram iniciar um processo de inovação e atualmente esperam as certificações devidas para começar a fabricação de seus próprios produtos. Isso não significa que deixarão de distribuir. Outro dado relevante é que a Biocam vende esses produtos de empresas que não são concorrentes, mas juntas permitem a Biocam uma ampla lista de produtos de uma linha que não se diferencia muito, de modo que podem oferecer aos clientes ao mesmo tempo.
} 
Essas empresas representantes são importantes e indispensáveis intermediários do fornecimento aos hospitais e demais serviços de saúde do estado de São Paulo. Entre seus produtos - cujas origens não variam muito, pois há de ser a Região Concentrada ou empresas estrangeiras - há serviços prestados aos equipamentos vendidos.

Como assistentes técnicos autorizados ou manutenções preventivas, até mesmo atividades mais sofisticadas, como a engenharia clínica, as atividades de manutenção se revelaram importantes formas de trabalho na economia urbana.

0 fato de que os equipamentos de saúde devem ter um acompanhamento mais de perto, pois se precisam de reparo o serviço deve ser o quanto antes, e um acompanhamento de um tipo preventivo, capaz de aferir e regular o equipamento com periodicidade, a manutenção de equipamentos médicos demanda os agentes locais.

Pois, se o aumento das demandas por saúde é associado à acelerada corrida científica e tecnológica como um processo de mútua implicação, à medida que técnicas são renovadas, ampliamse as demandas por serviços relacionados a esses objetos.

Para Granger (1994), o emprego de máquinas cada vez mais poderosas faz com que hoje essas máquinas de processar informação ganhem espaço nas funções e nas tarefas do executante. E escreve:

"De modo que o aspecto mais repetitivo das tarefas, há pouco justamente codificado pelo taylorismo, é em grande parte transferido para a máquina, e o papel do executante consiste cada vez mais no exercício de uma tecnicidade de segundo grau: um saber de supervisão, de manutenção do bom andamento, de reconhecimento da falhas e dos incidentes de funcionamento. No limite, ocorre até uma comunicação entre o homem e a máquina que ele utiliza.” (Granger, 1994:38)

Nessa direção, há empresas que prestam diferentes tipos de serviços de manutenção, tendo, com isso, uma forma autônoma de trabalho na região, ou como representantes de fabricantes. A LAC, empresa em Campinas, é representante exclusiva da $\mathrm{K}$ Takaoka, uma das grandes empresas nacionais. 
A ação da LAC traduz uma condição definida pela empresa-mãe, possui 18 funcionários e uma capilaridade e organização do trabalho que, embora dependente da Takaoka, possui grande importância na manutenção dos equipamentos distribuídos nos estabelecimentos de saúde da região, definida pela representação. Daremos mais atenção às atividades de manutenção no último capítulo.

Em Campinas, devemos mencionar a existência do Centro de Engenharia Biomédica da Unicamp, que realiza atividades em diferentes níveis de conhecimento em engenharia biomédica e física médica. $O$ CEB é um importante centro de formação profissional na região. A propósito, das empresas entrevistadas, todas mostraram relação recente ou mais antiga com o CEB.

Responsáveis pelo parque de equipamentos do Hospital das Clínicas da Unicamp, o CEB desenvolve atividades de manutenção, corretivas e preventivas, no hospital, assim como são o órgão responsável por adquirir e instalar os novos equipamentos no hospital.

A realidade de São José do Rio Preto, longe de ser comparável à de Campinas, mostra que as atividades de manutenção estão também articuladas com os cursos técnicos, mas não se apresentaram tão integradas e sustentadas de algum modo por atividades institucionais públicas de pesquisa.

As idéias de obsolescência planejada na produção, segundo a qual as coisas não eram feitas para durar, dirá Sennet (2006:130), são atualmente substituídas pelos atuais empenhos em gerenciamento de qualidade.

A manutenção dos equipamentos parece confirmar isso que diz Sennet (2006). Alguns equipamentos mais sofisticados possuem certa durabilidade, como tomógrafos, ressonância magnética, raios-x. No entanto, o sistemismo das técnicas informacionais permite que o controle hegemônico seja praticado não pela obsolescência do objeto, mas pelas partes.

Isto é, aquelas partes dos objetos que são as peças que participam da manutenção, ou mesmo os insumos necessário ao funcionamento do aparelho, como o contraste da ressonância, o gel do ultra-som, o colete de chumbo das tomografias, etc. 
Enquanto isso, crescem as formas de oligopolização, pois a dependência atual dos equipamentos de saúde desse monitoramento eletrônico dos equipamentos como um sistema técnico hospitalar moderno é premente por meio das atividades difundidas da manutenção preventiva e engenharia clínica.

o imperativo dessa manutenção sofisticada, em seu sistemismo técnico científico e informacional com os objetos, aparece como serviços agregados às compras dos aparelhos. Oferta de serviços pós-venda, garantias de manutenção preventiva por anos, tornamse mecanismos de empresas hegemônicas que terminam por instigar a modernização dos serviços.

Nesse sentido, os sistemas de objetos e ações ligados à manutenção de equipamentos mostram os atributos a força de algumas empresas. Fabricantes como os grandes conglomerados Siemens, Phillips, GE, com forte participação no mercado interno, facilitam a aquisição dos seus produtos, por meio de sua capacidade imperiosa de serem também financiadoras.

Os aparelhos de diagnósticos sofisticados, hoje necessidades tão banalizadas, são duráveis, mas, em contraposição, os compradores, que são em qualquer instância serviços de saúde, são convocados a usar seus insumos específicos, os quais aparecem em família de técnicas.

Nesse sentido, a unicidade da técnica mostra de que modo serviços públicos ou privados de saúde se tornam dependentes assíduos dessas grandes firmas. Não apenas pelos insumos à funcionalidade do aparelho, mas também pelas peças de manutenção que são exclusividades da marca, "segredos" do seu poder hegemônico.

Enquanto a importação de aparelhos que não produzimos nacionalmente é facilitada por lei, potencialidades produtivas dessas cidades à manutenção de equipamentos médicos são expropriadas. Formas mais autônomas de trabalho vão se tornando comprimidas por um mercado, cujo domínio vem criando dependência e subordinação de outros modos de fazer reparação.

Ainda faz-se importante ressaltar que são os médicos que decidem sobre qual equipamento comprar, ainda que o hospital tenha um conselho de engenharia clínica. A descrição técnica da qualidade terapêutica, por meio de um discurso competente do 
equipamento, convida a refletir sobre a proximidade entre médicos e indústria ${ }^{43}$.

Por outro lado, essa relação entre médico e indústria que já mencionamos no primeiro capítulo, não é desmedida, mas, pelo contrário, é parte intrínseca do fluxo de informação científica e tecnológica para a saúde.

E. Cordeiro (1980) já assinalava um complexo médicoindustrial para nomear a articulação entre a assistência médica, as redes de formação profissional (escolas, universidades), a indústria farmacêutica, a indústria produtora de equipamentos médicos e instrumentos de diagnóstico.

Para compreender os nexos atuais dessa relação, devemos acrescentar a participação dos hospitais na produção científica que serve à indústria, chamado pela literatura internacional de sistema biomédico de inovação.

Nesse sentido, os hospitais na economia urbana não apenas aglutinam atividades afins, mas pelo modo como o território é usado hoje, são fatores de desintegração dessa economia na região. Entretanto isso não se dá de modo dualista, pelo contrário, há interstícios na economia das cidades.

Por outro lado, o próprio sistema único de saúde, ao lado da difusão dos consumos, aparece como fator de dispersão, enquanto oportunidade para que empresas possam produzir e encontrar seus mercados em lugares distantes, pela complementaridade entre as formas de trabalho.

\footnotetext{
${ }^{43}$ Recentemente a Folha de São Paulo publicou uma notícia sobre uma ação judicial sofrida por uma grande empresa farmacêutica, Pfizer, e revelou o "ghostwriting", mecanismo que encomenda artigos científicos de pesquisa não comprovada e os submete à publicação em revista científica em co-autoria com um pesquisador convidado, como forma de legitimar produtos no mercado. Folha de São Paulo, 8 de setembro de 2010.
} 


\subsection{A criação das densidades normativas}

Atualmente, quando enfrentamos o modo como o Brasil vem lidando com as questões da saúde, entendendo-as para além da oferta dos serviços, somos trazidos à reflexão pelas idéias e práticas políticas do planejamento territorial e os modelos dos programas atuais.

As políticas industriais que hoje envolvem a esfera da saúde a compreendem no contexto do desenvolvimento produtivo nacional, bem como das políticas de ciência e tecnologia do país. Já suas idéias, não dispensam tradicional associação com a teoria dos pólos de crescimento de François Perroux.

Fazer notar os debates e nuanças históricas entre ciência regional e planejamento não é em qualquer instância tarefa nossa diante do que nos oferecem os estudos extensivos e aprofundados de grandes autores como Boudeville (1961), Lasuen (1969); Berry (1972), Furtado (1974), Santos (1979), Andrade (1987), Benko (1995), entre outros.

Podemos dizer, nesse sentido que o planejamento foi um dos conceitos-chave criados pelo sistema capitalista para disseminar em vários espaços nacionais o capital internacionalizado (Santos, 1979; 2003:16).

"Pelo mero fato de que toda teoria do comércio internacional está integrada à teoria da localização, o planejamento espacial ganha importância ainda maior com a internacionalização do capital” (Santos, 2003:24)

Do mesmo modo, quando o desenvolvimento é apenas possível pelo estabelecimento de modelos de tecnologia, de organização e utilização do capital, continuamos a perceber os esforços de um certo planejamento na sua versão primorosa ao serviço do capital.

Em tempos de globalização, algumas políticas orientadas para o desenvolvimento de "espaços econômicos" parecem revelar o renovado vigor das importadas modelizações que, nesses termos, são responsáveis por uma planificação indissociável da desintegração das economias e da sociedade. 
Importantes autores já mostraram a desigualdade dos efeitos das modernizações, como Mabogunje (1968), Celso Furtado (1974), Santos (1979), entre outros. A visão crítica não está sobre a efetividade que os cálculos permitem alcançar, mas sim nas aplicações, cujos cálculos abstratos abandonam a definição de um espaço geográfico, espaço de todos os agentes.

A natureza das atuais centralidades produtivas obedece a novos fatores de produção. As modernas fabricações têm na pesquisa técnico-científica um mote muito mais importante e, nesse sentido, possuem suas próprias exigências em matéria de localização.

A organização do território, inseparável da distribuição dos recursos, está marcada pelos conteúdos da tecnociência, informação e finanças atuais, onde apenas alguns lugares são constituídos com essa carga de racionalidade.

A concessão de recursos públicos a cidades e regiões onde o capital se acumula rapidamente demonstra as necessidades atuais de que o excedente se faça antes de tudo pelo fluxo. Expondo a natureza do espaço contemporâneo à natureza da política atual, o planejamento se atualiza para desempenhar seu papel na acumulação capitalista.

Como nos ensina Correa (2006:30), a rede urbana se apresenta como a forma espacial que viabiliza a existência de ciclos de exploração, onde a singularidade de cada cidade só se verifica em razão de sua inserção em uma parte específica do território submetido ao processo de criação, apropriação e circulação do valor excedente.

As forças de modernização são extremamente seletivas, tanto por suas formas como pelos efeitos. Porém, é pela urbanização, que tanto resulta como alimenta esse processo, que o lugar é tomado pela quantidade e qualidade de capital que o constitui e dá valor aos novos objetos e ações.

Essa intensificação de capital em alguns lugares é reveladora, como demonstra Santos (2003:152): "as possibilidades de retenção de uma parte do excedente e de sua redistribuição parecem ser maiores em certos pontos do espaço do que outros."

o próprio discurso do desenvolvimento imprime esse objetivo quando define as potencialidades regionais para articular o 
apoio dos programas de governo. Vemos a exigência de que os lugares da ação sejam globais e, para isso, o território como norma (Santos, 1996) age como condição para garantir a uma dada produção uma produtividade maior.

A ética da competitividade que caracteriza nosso tempo deixou de ser aquela da velha concorrência, onde se admitia o outro como estímulo e não para tomar seu lugar. Hoje, o lugar da competição na ordem societária justifica o individualismo não apenas econômico, ou político, mas também, territorial (Santos, 2000:47).

Os próprios hospitais filantrópicos e privados não são a parte dessa racionalidade quando se valem das modernizações para atrair "clientes", sendo este o modo de aumentar a produtividade e aumentar seus rendimentos. Os hospitais, como os fixos geográficos da prestação de serviços de saúde, são expressão dessa lógica que se instala.

Alguns aspectos contemporâneos da busca por eficiência e produtividade estão expressos pelas novas modalidades do desenvolvimento ligados ao planejamento na forma dos Arranjos Produtivos Locais e Parques Tecnológicos.

Como vimos, no âmbito estadual, o desenvolvimento da indústria nacional ligada à saúde revela destaque de algumas cidades do interior do estado de São Paulo. Já analisamos alguns fatores gerais dessa seleção, e sabemos que as atuais necessidades da organização do trabalho limitam os lugares da produção moderna.

Campinas, Ribeirão Preto e São José do Rio Preto estão no eixo dos programas ligados às especializações produtivas do Estado de São Paulo. Entendidas pelas suas "vocações regionais ao crescimento econômico", essas cidades passam a integrar o desenvolvimento produtivo na área da saúde.

Nesse sentido, nossa análise do planejamento se dá pelas particularidades que se observam na divisão do trabalho em cada cidade e no processo de urbanização. Pois essas, tanto resultam quanto alimentam as intencionalidades que permitem à valorização planificada de tais lugares.

"É o lugar que oferece ao movimento do mundo a possibilidade de sua realização mais eficaz”, ensina Santos (1996:271), pois 
são porções do território onde a racionalidade hegemônica se torna uma oportunidade.

A seletividade espacial das modernizações por parte do Estado, e os interesses distantes, vistos pelo comando das variáveis da tecnologia, da informação e das finanças por parte de grandes poderes empresariais, incitam uma reflexão mais além do crescimento pelas estatísticas que o PIB oferece.

Nos últimos anos, governo e indústria têm procurado manter o mercado de equipamentos médico-hospitalares em crescimento com programas de ações conjuntas.

No âmbito federal, a produção desses objetos integra a estratégia de aumento da capacidade inovadora das empresas nacionais e o objetivo de dar "sustentabilidade" ao atual ciclo de expansão da economia brasileira a partir de "setores produtivos”.

Por meio da Política Industrial, Tecnológica e de Comércio Exterior (PITCE/2004) e do Programa de Desenvolvimento Produtivo (PDP/2008), o governo tem empenhado esforço para transformar o sistema produtivo dos equipamentos médicos em área estratégica ao desenvolvimento nacional ${ }^{44}$.

0 recente crescimento da produção nacional de equipamentos médicos, com expansão e diversificação do mercado interno, ao lado da retração de produtos tecnologicamente mais complexos e o aumento das importações, têm orientado medidas públicas para fortalecer a indústria nacional.

Elevar os investimentos em inovação, aumentar e diversificar a participação do país no comércio mundial desses produtos e dinamizar as micro e pequenas empresas são medidas à competitividade do ramo que, por sua vez, definem o escopo do desenvolvimento esperado.

Nesse sentido, os programas de desenvolvimento produtivo, associados à política científica e tecnológica do país nos permitiram testemunhar de que modo a saúde, tomada como instância econômica, participa desse processo de totalização.

\footnotetext{
${ }^{44}$ Sobre esse debate atual ver Viana, A. L.; Ibañez, N.; Elias, P. E. (Org.) Saúde Desenvolvimento
} e Território, Ed. Hucitec, São Paulo, 2009. 
Historicamente no país, e é possível dizer, ainda hoje, as áreas da saúde e agricultura revelam a existência de uma convergência entre a geração da pesquisa pública com as demandas do setor privado (Furtado, 2005:44).

Entretanto, o que nos parece novo é a política industrial para a saúde concebida pelo planejamento urbano. As políticas de especialização produtiva aplicadas pelos programas de desenvolvimento do estado de São Paulo vêm autorizar Campinas, Ribeirão Preto e São José do Rio Preto na realização de algumas possibilidades do atual período.

Tais fatos nos levam ao arcabouço institucional dos programas, responsável pelo aumento das densidades normativas ${ }^{45}$ (Silveira, 1996). Criadas para dirigir as atividades de produção dos equipamentos médicos, as normas vêm inscrever as cidades de forma renovada na divisão do trabalho hegemônico.

Nesse sentido, ainda convém apontar algumas outras nuanças das políticas nacionais nas quais as cidades estão abraçadas. De modo geral, sabemos que a política de ciência e tecnologia no âmbito internacional busca maiores interações entre a pesquisa pública e privada na economia.

Furtado (2005:41) defende que esse novo padrão global consiste muito mais em uma mudança de ênfase na gestão das organizações existentes do que uma nova orientação dos gastos públicos.

Justificado pelas importantes mudanças produtivas e econômicas no plano internacional, o imperativo da competitividade parece fazer com que um papel cada vez mais relevante nas decisões de pesquisa seja assumido pela iniciativa privada.

\footnotetext{
${ }_{45}$ Santos (1994) propõe a abordagem das modernizações pela densidade da técnica e da informação na constituição dos lugares. Dirá (Santos, 1994:8) que a densidade da técnica está representada pelos "espaços inteligentes dispostos a atender prontamente as intenções dos que o conceberam, produziram e instalaram" e a densidade da informação se refere "aos graus de exterioridade do lugar, sua propensão a entrar em relação com outros lugares, privilegiando setores e atores". Silveira (1997:43) assevera que hoje, mais do que antes, a técnica impõe modos de regulação, que buscam "revogar a pluralidade de marcos regulatórios para afirmar uma única regulação". Nesse sentido, Silveira (1997:43) acrescenta àquelas duas a densidade normativa, como a construção mais aperfeiçoada da ordem global, onde identificaríamos aquelas áreas em que a "lei do mercado e as demais normas globais agem mais profundamente, arrostando a exígua resistência das normas locais".
} 
Seguindo a tendência dos países desenvolvidos ocidentais desde o pós-guerra, o Estado brasileiro passa a ser indutor da atuação de demais agentes, sobretudo de empresas, como modelo de política científica e tecnológica para o país.

Ademais, como assevera Santos (2003:55), a unificação do trabalho, permitida pelo trabalho intelectual como fator predominante da produção, corresponde a um processo de organização do espaço representado por uma verdadeira difusão dos métodos de produção científica.

O Brasil acompanha esse processo de forma particular. 0 sistema de ciência e tecnologia está concentrado no Estado e resiste como formação social pois, até o fim dos anos 1980, era quase insignificante a participação de instituições não-públicas na formulação da política de ciência e tecnologia.

É a partir da Constituição Federal de 1988 que decisivamente a indústria nacional, no contexto da competitividade internacional, ganha outra implicação. Em direção às pesquisas aplicadas, os Planos Plurianuais, desde então obrigatórios às ações em cada governo, revelaram novos rumos da política de ciência e tecnologia no país.

Desde 2000, atesta Theis (2009:74), os esforços em ciência e tecnologia foram orientados à inovação, passando a ganhar maior centralidade o setor produtivo. Ainda, sem descurar deste, os dois Planos Plurianuais a partir de 2004 vêm anunciar a inclusão social no escopo das questões da ciência e tecnologia.

Vale dizer que a década de 1990, o Brasil passa por grandes transformações políticas e econômicas para que se dê sua inserção na atual divisão internacional do trabalho. Os imperativos de mercado tornado global passam a acelerar os acréscimos de ciência e tecnologia aos lugares, mas não é a inovação o mote ao desenvolvimento.

São, pois, por esses parâmetros que a saúde irá integrar as políticas de desenvolvimento do governo federal. o Complexo Industrial da Saúde (CIS), concebido como um braço da política de desenvolvimento produtivo, possui um grupo executivo ${ }^{46}$, cuja gestão é centralizada no Ministério da Saúde.

\footnotetext{
${ }^{46}$ Ministério do Desenvolvimento da Indústria e Comércio Exterior, Ministério da Ciência e Tecnologia, Agencia Nacional de Vigilância Sanitária, Banco Nacional de Desenvolvimento
} 
Essa articulação coordenada pelo Ministério da Saúde, e não pelo Ministério do Desenvolvimento Industrial e Comércio Exterior, mostra a tentativa de conciliar a política de saúde, comprometida com o acesso universal, com aquelas metas da política de desenvolvimento industrial.

Embora essa preocupação tenha ficado reduzida aos fármacos e medicamentos nos primeiros dois anos, o Complexo Industrial da Saúde tem dado recente importância aos equipamentos médicos, tendo em vista que a intensificação das aquisições desses objetos hospitalares fez perceber o impacto deficitário na balança comercial ligada a tais produtos.

É certo que não se explica pelo déficit da balança, mas além de que esse dado aparece no discurso das justificações institucionais, é válido ressaltar a política de desenvolvimento nacional atual como modo de inserção na divisão internacional do trabalho e o papel da saúde como variável técnica científica e informacional desse projeto.

Nesse contexto, há o reconhecimento da tecnociência que ressalta a vulnerabilidade do sistema de saúde pelas importações, enquanto o desenvolvimento econômico deixa que a saúde se valha como política social de interesse abrangente.

Os equipamentos médico-hospitalares não são apenas os tomógrafos computadorizados, fabricados pelos grandes conglomerados, mas também às agulhas, os afastadores de língua, os cateteres, as paramentas cirúrgicas, o que representa uma gama de objetos.

Esses materiais de consumo hospitalar, assim como insumos de laboratório apresentaram, entre 2000 e 2006, as maiores taxas de crescimento das importações dentre os subsetores de equipamentos médicos. Isso é explicado, sobretudo, pelo avanço da China no mercado mundial desses objetos.

A produção nacional diante das novas dependências criadas pela internacionalização da economia, e seus efeitos sobre a política de saúde, imprimiram nova preocupação política que

Econômico e Social, Financiadora de Estudos e Projetos, Agência Brasileira de Desenvolvimento Industrial (ABDI), Fundação Oswaldo Cruz, Ministério da Fazenda, das Relações Exteriores e Casa Civil da Presidência da República, ainda, articulados com diferentes entidades da Sociedade Civil. Portaria n 1.942 de 17 de Setembro de 2008. 
passou a ser entendida como oportunidade a certa idéia de desenvolvimento econômico.

Através do Complexo Industrial da Saúde, busca-se desenvolver tecnologia para produzir, no país, produtos estratégicos para o sistema de saúde. Nesse sentido, o âmbito da saúde se alarga no interior das relações intergovernamentais. A questão dos radiofármacos é exemplar.

0 Brasil é totalmente dependente de molibidênio $99^{47}$, matéria-prima indispensável ao exame de cânceres e outras doenças específicas. O tálio era a substância utilizada anterior às modernizações recentes nos equipamentos, atualmente, o tecnécio formado a partir do molibdênio é usado em quase a totalidade desses exames no mundo.

É através do Complexo Industrial da Saúde que o Ministério da Saúde vem articulando os interesses da saúde com a política nuclear capaz de gerar o produto nacionalmente, buscando com isso diminuir a dependência externa e fragilidade do sistema de saúde.

Essa política mais ampla estaria envolvida na proposta de construção de um reator nuclear cuja base tecnológica revela interesse estratégico, por ser uma plataforma que serve à produção de outros elementos não apenas à saúde.

A despeito desse caso específico, a proposta de desenhar medidas que elevem a capacidade tecnológica da indústria

\footnotetext{
${ }^{47}$ Em 14 de maio de 2009, o reator canadense, que produzia todo o Molibdênio consumido no Brasil e fornecia a diversos países do mundo fechou. Com a falta da substância, hospitais públicos e privados tiveram que diminuir o número de exames, selecionar pacientes e realizar exames alternativos na tentativa de continuar o trabalho de diagnosticar as doenças como os cânceres. O molibdênio 99 é uma substância radioativa, importada do Canadá e processada em São Paulo pelo INPE, que envia cargas semanais para todo o país, pois não é possível armazenar o material por muito tempo. Nos laboratórios, de acordo com o exame a ser feito, o molibdênio gerador de tecnécio é misturado a um fármaco específico e aplicado no paciente. Em um equipamento chamado Gama Câmara, a substância emite radiações no órgão a ser examinado, destacando-o como contraste, formando imagens digitais. Numa comparação, o exame de cintilografia, que usa o molibdênio, difere do raio-x, porque neste é a máquina quem emite as radiações e naquele é o paciente que emite as ondas radioativas captadas pelos equipamentos. O Brasil passou, então, a importar da Argentina um terço do material necessário para suprir a demanda nacional. Por se tratar de um produto desse porte tecnológico e desse nível de dependência para os serviços de saúde, o governo então estuda não apenas como suprir essa demanda a curto prazo, mas também a longo prazo, pela construção de um reator nuclear capaz de gerar a substância, assim como ser base tecnológica para a fabricação de outros produtos nacionais.
} 
nacional tem sido conduzida pelo fórum permanente do grupo executivo do CIS. A propósito desses interesses, a regulação sanitária sobre os produtos e fabricações dos equipamentos médicos tem sido um mecanismo nesse processo.

É nesse amplo contexto de projetos e programas federais que o estado de São Paulo, região onde se concentra enorme parte das empresas produtoras de objetos médicos, empenha-se para promover de um modo complexo a modernização de equipamentos médicohospitalares.

Com vistas a aumentar a competitividade da indústria paulista dentro do país, assim como dar efetividade às metas do governo federal, as políticas de especialização produtiva serão vetores de novas compartimentações e novos dinamismos territoriais nas três cidades visitadas.

A irrecusável modernização da medicina, mas, sobretudo, a atual divisão internacional do trabalho ligada à produção global dos equipamentos médico-hospitalares exalta, nesses lugares, assim como na totalidade da formação socioespacial, uma aceleração normativa que se impõe sobre as formas de trabalho.

Como ensina Silveira (2000:216), "as técnicas aparecem-nos como um sistema, um sistema de objetos, mas também, um sistema de organização, um sistema de informações e, sobretudo, um sistema de normas."

Novos métodos organizacionais, novos padrões de qualidade dos processos produtivos e dos produtos, parâmetros internacionais, multiplicação das instâncias de controle e de fiscalização, são alguns dos resultados da complexização da técnica do nosso tempo, em particular, da tecnologia médica.

Se antes a proximidade das empresas na forma do que eram os distritos industriais parece que esteve para catalisar trocas tecnológicas eficientes, atualmente, o novo sistema técnico constituído por técnicas mais flexíveis, vem invocar mais e mais protocolos organizacionais, daí enquadramentos normativos.

Essas cidades refazem sua coerência histórica a partir desses novos eventos, possíveis ali pela predominância do trabalho intelectual que autoriza os comandos distantes das etapas da produção desempenhadas nessas cidades, que passam a um novo papel na divisão territorial do trabalho da nação e do mundo. 
Segundo Santos (1996:115), os eventos são um veículo das possibilidades do mundo assim como um vetor das possibilidades existentes numa formação social, num lugar. Como são, todos, presente, os eventos apenas se realizam quando criam nova geografia.

Nesse sentido, como assevera Silveira (1997:37), a refuncionalização dos eventos no lugar promove um processo dialético, onde algumas normas, pertencentes à atual ordem global, antecedem à modernização material e chamam a si objetos e ações contemporâneos.

É nesse contexto de incremento do capital e da organização do trabalho em alguns lugares que é tornada mais espessa a divisão do trabalho. Por sua vez, as possibilidades de coexistência de atividades com menor capital, tecnologia e organização e a multiplicação de novas formas de cooperação são resultados do mesmo processo.

"O sistema territorial comandado por esse subsistema hegemônico supõe uma convivência interna em cada país com os outros muitos subsistemas. O resultado é que cada país é territorialmente definido não mais pelo subsistema hegemônico, mas pelos outros, porque é a combinação entre eles que nos vai permitir reconhecer e definir, através da análise, as novas amálgamas.” (Santos, 1988:59)

Enquanto os empenhos normativos desses programas mostram de que maneira o Estado vem mediar e presentificar as possibilidades da moderna medicina, a conformação material única das cidades de Campinas, Ribeirão Preto, São José do Rio Preto, manifesta de forma singular a imperatividade da regulação.

Pois o processo de especialização dos lugares vem remodelar a materialidade e as normas, autorizando novas solidariedades do trabalho vivo. A continuidade temporal e a coerência espacial, que singulariza cada cidade, mostra seu respectivo conjunto de eventos geografizados.

Daí nossa perspectiva de discutir a situação geográfica em tais cidades a partir da proposta de Silveira (1999), isto é, vinculada à noção de evento:

"Por isso, uma situação geográfica supõe uma localização material e relacional (sítio e situação), mas vai além porque nos conduz à 
pergunta pela coisa que inclui o momento da sua construção e seu movimento histórico" (Silveira, 1999:22)

De modo geral, as situações geográficas nas cidades mostram o papel de cientificidade e extrema organização na constituição dos circuitos da economia urbana. Enquanto eventos geografizados, tais programas se tornaram significativos para que a existência mais clara de um circuito superior marginal vinculado aos equipamentos médicos pudesse se revelar.

Importa ressaltar a ênfase que as micro e pequenas empresas de equipamentos médicos assume nesse processo de atualização da dinâmica produtiva no âmbito federal e estadual. Vimos que quase $90 \%$ da produção nacional se realiza por micro, pequenas e médias empresas.

Daí também a política industrial desses objetos técnicos se empenhar na valorização das empresas pequenas. Os Arranjos Produtivos Locais, como modelo de planejamento que atribui peso aos fatores de localização em função de "setores" produtivos, mostram como Ribeirão Preto se torna adequada às modelizações atuais.

Para Benko e Lipietz (1994:248), a planificação racional invocada na esteira da concepção dos distritos marshallianos encontra no que, antes, fora uma "atmosfera" sua contrapartida atual na cultura, isto é, na experiência compreendida por uma maior espontaneidade dos agentes.

Nessa direção, Ribeiro (2008:194) faz uma distinção entre regionalização como fato, que independe da ação hegemônica do presente, e regionalização como ferramenta, que toma forma pelo planejamento conduzido pelo Estado. Assim, a planificação atual compreende que seja conhecida a regionalização como fato para ser utilizada como ferramenta pelos agentes hegemônicos.

Podemos observar, nesse sentido, que "o processo social está sempre deixando heranças que acabam constituindo uma condição para as novas etapas”. (Santos, 1996:112). Pois a situação geográfica definida para Ribeirão Preto revela esse processo de transformação da produção e organização do mercado pela presentificação dos parâmetros da tecnociência da informação e da finança na cidade. 
Sendo for possível dizer de uma inércia dinâmica (Santos, 1985) é em proveito desta que uma nova cultura empreendedora ligada aos equipamentos médicos é criada, a partir da participação de novos agentes nesse processo de modernização das forças produtivas na região e no país.

A aproximação entre difusão de inovação e modernização fora feita por grandes autores, onde podemos mencionar Akin Mabogunje (1973) e Celso Furtado (1974) quando nos ensinam a observar as causas do sistema capitalista pelos efeitos das modernizações próprios dos países subdesenvolvidos.

Mabogunje (1973) quando explica que os processos de urbanização se dão em sociedades não-industriais e Furtado (1974), ao ensinar que o subdesenvolvimento não é uma etapa do processo de desenvolvimento, desmistificam dois pilares das teorias econômicas que vêm justificar as inovações como caminho ao desenvolvimento.

Nesse sentido, Santos (1977) assevera sobre a não existência de um dualismo nos países subdesenvolvidos, tampouco de um dualismo urbano na economia das cidades desses países. Daí sua interpretação da particularidade da formação socioespacial de cada país, diante do movimento do mundo.

Daí dizer que somente aliada à história da sociedade local, a história da sociedade mundial pode "servir como fundamento à compreensão da realidade espacial e permitir a sua transformação a serviço do homem. Pois a História não se escreve fora do espaço, e não há sociedade a-espacial. o espaço, ele mesmo, é social."

Entendendo, então, que as modernizações adquirem uma concreticidade que é própria a cada país, as rugosidades (Santos, 1978) assumem um papel importante nas nossas observações. Silveira (1997) diz:

"O lugar surge como o reino da superposição de vetores e rugosidades, onde o acontecer tem uma extensão e uma densidade. A extensão significaria escala de império e a densidade ganha diversas formas: técnica, informacional (Santos, 1994) e normativa" (Silveira, 1997:32).

Em Ribeirão Preto, o Arranjo Produtivo Local de Equipamentos Médico-hospitalares compreende a cidade como um todo, quer 
dizer, não é uma área que no interior do município esteja definida para tal.

Entretanto, o próprio $\mathrm{APL}$, por resolução ${ }^{48}$, se limita a investir em algumas empresas, embora atualmente vemos maior o número de empresas sob a atenção dos gestores do APL. O que nos leva à consideração do caráter sempre seletivo das modernizações, ainda que, pelo discurso, essa difusão esteja direcionada a uma cidade como um todo.

A missão de transformar a região num centro de referência de ciência e tecnologia para a saúde está gerida pela FIPASE, fundação responsável pela gestão do pólo avançado de saúde de Ribeirão Preto.

Instituição pública de direito privado, o órgão promove o desenvolvimento da indústria de equipamentos e produtos da saúde no município, colaborando para a expansão desta nos mercados nacional e internacional. É esse o esboço do que pretende o APL, focado nas empresas já existentes na cidade.

\footnotetext{
${ }^{48}$ O Edital MCT/ CNPQ/ Ação Transversal I n. 039/2008, da Seleção Pública de Propostas para apoiar projetos que envolvam ações de capacitação, formação e pesquisas tecnológicas visando o desenvolvimento de Arranjos Produtivos Locais, escreve: 1) Dos Objetivos: o presente projeto, com base no atual estado de desenvolvimento tecnológico do setor, visa deflagar um processo de capacitação tecnológica em algumas empresas do mesmo com a finalidade de melhorar a competitividade nos mercados nacionais e internacionais. 2) Dos Métodos: visando a melhoria da competitividade, nivelamento da qualidade e produtividade e busca de novos mercados, as ações sugeridas estão centradas em: capacitação em gestão, capacitação em produção, melhoria do processo, promoção e comercialização. Estas ações visam consolidar a região de forma profissional e competitiva, que almeja os mercados internos e externos com qualidade e preço competitivo, tornando-se referência nacional. A estratégia das empresas para implementação do projeto deverá concentrar-se nas principais forças restritivas e nos pontos fortes, conforme as três premissas apontadas pelas empresas, durante a elaboração da uma Oficina de Planejamento Participativo: "aumentar as vendas, diminuir os custos e focar a inovação tecnológica”. Utilizando uma visão tática sobre as premissas, definiuse componentes gerenciáveis a curto, médio e longo prazo, tendo como foco estratégico a capacitação para a Boas Práticas de Fabricação, a capacitação da mão de obras e o desenvolvimento dos gestores das empresas. O projeto deverá contemplar inicialmente um conjunto de pelo menos 20 empresas do setor de EMHO de capital nacional, de porte predominantemente pequeno. Os atores convidados são a ABDI, ABIMO, SINAEMO. As instituições colaboradoras são CIESP, FIESP, SEBRAE SP, SENAI, Prefeitura Municipal de Ribeirão Preto e 21 empresas do setor de equipamentos médico-hospitalares do município. A instituição executora é a FIPASE - Texto extraído do documento que institui o Programa de Desenvolvimento do Arranjo Produtivo Local de Equipamentos Médico, Hospitalar e Odontológico do Município de Ribeirão Preto e Região e Edital MCT/ CNPQ/ Ação Transversal I n. 039/2008.
} 
Entretanto, o projeto é ainda mais amplo, pois envolve a idealização e execução do Parque Tecnológico da Saúde no município, cuja efetivação está em andamento.

Ainda, vemos o incentivo à criação de novas empresas de base tecnológica nesta área, assim como a transformação do conhecimento gerado nas universidades e centros de pesquisa em atividades produtivas. Esse é o esboço do programa SUPERA, a incubadora de empresas de que é responsável.

Ademais, essa incubadora é também prestadora de serviços tecnológicos, embora o mais novo Centro de Desenvolvimento e Inovação Aplicada (CEDINA), inaugurado em 2010, já como antecipação ao Parque Tecnológico de Ribeirão Preto, esperado na cidade, passe agora a realizar tais serviços.

o CEDINA aparece como um sistema de objetos e ações representativo da cooperação entre empresas e instituições de pesquisa públicas e privadas, assim como da formação de novas redes de conhecimento. Da mesma forma, aparece como uma infraestrutura de referência ligada às áreas da saúde e biotecnologia de enorme valia para o desenvolvimento que se espera da produção nacional como um todo.

Tendo em vista as demandas por certificação de produtos, o CEDINA vem sendo acreditado pelo Instituto Nacional de Metrologia, Normalização e Qualidade, para que possa certificar produtos para o mercado nacional, junto a Agencia Nacional de Vigilância Sanitária (ANVISA), e para o mercado externo, isto é, os selos CE, FDA que são os principais.

Ainda, o CEDINA realiza pesquisas de potenciais conhecimentos aptos ao desenvolvimento de inovações de produtos ou processos, e oferece serviços tecnológicos, como os ensaios e testes necessários a avaliar a conformidade do produto durante 0 processo de desenvolvimento pelas empresas.

Vale a ressalva de que essas atividades do CEDINA compreendem uma disponibilidade recém-nascida no país, pois datam de 2010. Com todo esse sistema de engenharia que vem sendo abrigado em Ribeirão Preto, podemos falar do papel que terá o CEDINA na atração de agentes produtores em outras cidades vizinhas, como São Carlos, São José do Rio Preto, entre outras. 
Captando recursos de várias fontes e fazendo parcerias (CNPq, CAPES, FAPESP, FINEP, SEBRAE, PMRP, SPPT/FAPESP, Nossa Caixa Desenvolvimento, receitas financeiras, empresas incubadas e inscrições de eventos) para o desenvolvimento de projetos, a FIPASE organiza e integra as ações de diferentes atores locais e longínquos.

É importante ressaltar que a natureza diferente dos agentes representa, antes de mais nada, a assimetria de suas forças, as posições hierárquicas e de poder pressupostas pelas diferentes capacidades de modificar os sistemas de objetos e ações, sob o qual, com efeito, os outros estarão subordinados.

Nesse sentido, promover um sistema de informação especializada para a comunicação entre agentes com diferentes atribuições não será algo menos importante nesse processo de difusão de inovações.

Em Ribeirão Preto, o Arranjo Produtivo de equipamentos médicos impele a necessidade de uma linguagem comum entre os agentes, atestando a comunicação como requisito relevante do estabelecimento das redes de difusão.

Para que se dê a solidariedade entre diferentes agentes, reconhecemos, pois, a importância de algum papel da FIPASE na coordenação funcional e adequação das comunicações na rede, de modo que o discurso que preexiste no enraizamento das práticas pretéritas seja também alterado.

Como nos lembra Silveira (2007:11), "quanto maior a racionalização do território, porque fundada em um cálculo, maior a irracionalidade e o número de desconformes. E quanto maior a irracionalidade, mais necessidade de discurso para intentar produzir convencimento"

A FIPASE mostra-se, assim, como o órgão de gestão da aceleração desse processo de expansão e densificação das variáveis definidoras da modernidade atual em Ribeirão Preto. Os aconteceres da cidade serão alargados não apenas pelos circuitos produtivos, mas também pela intensificação das cooperações dirigidas à produção local.

Vemos como a divisão do trabalho mais moderna impõe novas formas e nexos de cooperação e controle. Esse processo assinala novas e importantes solidariedades organizacionais na região. 
Ainda que a originalidade da cidade seja a condição prévia, muitas lógicas externas passam a compor seu cotidiano, em que vemos criar novas cooperações, mas também novas fragmentações.

\subsubsection{Alguns efeitos nas cidades de Campinas Ribeirão Preto e São José do Rio Preto}

A viabilidade da teoria da difusão das inovações de Hagerstrand (1962) a serviço da concepção e aplicação de modelos matemáticos fortaleceu seu viés utilitário. A despeito disso, trazer à geografia o esforço sistemático de tornar empírico o tempo é reconhecidamente pioneiro.

Entretanto, Santos (1996:42) é quem nos ensina a tratar o espaço em termos de tempo, quando nosso interesse recai sobre casos específicos e queremos ir mais além das mudanças espaciais impostas pelo próprio período aos lugares.

É na interpretação da vida ativa dos diferentes agentes da economia urbana que esse tempo ainda mais concreto se expressa. As diferentes divisões do trabalho nos autorizam estabelecer o que Sartre (1960) chamou de temporalizações práticas, isto é, formas particulares de utilizar esse tempo mais geral.

Cada lugar é então reconhecido por aconteceres que têm origem no mundo, mas que somente se realizam nos lugares. Assim, se os materiais que constituem o movimento do mundo são os mesmos, é por suas combinações diversas que o mundo se realiza através dos lugares. Daí a noção de escala ser dada em função do tempo, isto é, tempos empíricos que são divisões funcionais do tempo.

Nesse sentido, aproximar do acontecer dos lugares e as divisões do trabalho que permite tempos internos mais lentos, racionalidades que respondem a uma ordem dos lugares, significa ter atenção voltada ao tempo interno dos lugares.

À medida que Ribeirão Preto se revaloriza no sistema global, porções da cidade são desvalorizadas. Os fluxos alimentados pela informação e pelo dinheiro tornam hegemônicas as ações coletivas. A economia urbana é segmentada na formação socioespacial como um todo, pela depreciação relativa de divisões territoriais do trabalho pretéritas.

Objetos se tornam velhos por serem menos informados, sendo que aquelas empresas que não alcançam a capacidade de acompanhar 
os parâmetros rígidos das novas normas, com efeito, não atingem o incentivo que se limita aos "campeões". Isso se dá mesmo no espaço intra-urbano, ainda que o discurso pareça se referir à cidade como um todo.

A forte demanda tecnocientífica e informacional do ramo dos equipamentos médicos se torna um meio onde podemos observar o reforço às desigualdades socioespaciais. Acredita-se mobilizar uma fonte de recursos à produção nacional associando demanda empresarial à geração de tecnologia do setor acadêmico.

De qualquer modo, podemos perceber que no âmbito da competitividade global, a saúde moderna, que nos impõe a necessidade de seus objetos novos, vale-se da capacidade de agentes hegemônicos para criar e recriar as variáveis definidoras do período por meio da inovação.

A modalidade de fomento que, a partir da década de 1990, enfatiza a promoção de interações entre universidades e empresas, foi observada nas três cidades visitadas, entretanto, cada uma apresentou esse contexto de pesquisa a partir de arranjos distintos, respondendo à racionalidade própria do lugar.

Aliás, vem sendo significativo o papel do Ministério da Saúde na articulação da capacidade de institutos de pesquisa e universidades do país com as necessidades de mudança do patamar tecnológico da produção nacional dos equipamentos médicos.

Como não faz investimento na indústria, o Ministério da Saúde vem usando a questão da certificação de métodos e produtos como meio de promoção dessa articulação. A situação geográfica identificada em Campinas revela a configuração desse verdadeiro sistema de inovação em saúde, que pudemos observar por diferentes perspectivas.

Estratégia em relação aos interesses ligados ao Complexo Industrial da Saúde, o Ministério da Saúde vem investindo em infraestrutura tecnológica de laboratórios que fazem ensaios para a certificação de produtos na Universidade Estadual de Campinas, na Universidade de São Paulo e na Universidade Federal do Rio Grande do Sul.

Ampliando a capacidade operacional de emissão desses selos, tornando a produção mais "segura", o objetivo de elevar o nível 
tecnológico nacional torna-se um processo encaminhado. Nesse sentido, acredita-se que a infraestrutura mobilizada com base na ação regulatória cria a vantagem de nivelar por cima a competição.

A lógica dessa operação consiste em que a certificação cada vez mais ampla dos produtos, de acordo com os novos parâmetros, impele as outras empresas fabricantes a também investir em inovação.

Também, como meio de induzir esse sistema, o Ministério da Saúde vem fazendo parcerias com órgãos públicos, como a Financiadora de Estudos e Projetos (FINEP), o Ministério da Ciência e Tecnologia para o lançamento de editais cooperativos entre institutos de ciência e tecnologia e empresas.

Ainda, por meio do reaparelhamento desses institutos, o Ministério da Saúde tem forçado a chamada transferência tecnológica entre as instituições de pesquisa e as empresas, buscando minimizar a dependência de tecnologias externas.

Nessa direção, em Campinas, por outra perspectiva, pudemos observar que a existência das incubadoras tecnológicas permitiu o surgimento e consolidação de algumas empresas de equipamentos médicos na região.

Nesse processo, essas empresas incubadas, quando ingressam no mercado, já possuem um grau de organização e tecnologia maior do que aquelas que nascem de demandas menos modernas. De todo modo, pudemos observar que, em Campinas, as empresas fabricantes possuem maior nível tecnológico que as outras duas cidades, a não ser se olhamos apenas as grandes empresas do ramo produtivo nacional.

Por outro lado há também o caminho inverso, quando a existência de uma empresa na cidade serve aos testes para desenvolvimento de novos produtos. Como a Komluz que, na década de 1980, serviu ao Ministério da Ciência e Tecnologia para projetar e desenvolver equipamentos cirúrgicos com fibra ótica ${ }^{49}$.

\footnotetext{
49 As aplicações são em endoscopia clínica, vídeo endoscopia, iluminação auxiliar móvel ou fixa para exames clínicos e procedimentos cirúrgicos, polimerização em odontologia, iluminação de instrumentos com fibra ótica, transiluminação corporal, iluminação especial para sistemas óticos.
} 
Outra menção possível é o caso de pesquisadores que, por encontrar um interesse econômico em seus trabalhos, abrem seus próprios empreendimentos. Apesar desse fenômeno ser mais ralo do que as parcerias entre as universidades e as empresas, vimos que em Campinas é maior essa possibilidade.

Campinas, por ter uma densidade de meios de formação e conhecimento técnico-científico informacional e uma demanda incessante por saúde, deixa brotar atividades que surgem para suprir diferentes mercados. Nesses termos, esse efeito também ocorre em Ribeirão Preto, pelo peso da Faculdade de Medicina da Universidade de São Paulo.

0 conteúdo técnico científico e informacional das três cidades pôde mostrar que a existência de instituições de ensino de diferentes níveis de escolaridade, técnicas e superiores, de diferente natureza, SENAI, SENAC, Universidades públicas e privadas, assim como as diferentes áreas que confluem aos objetos médicos, como a engenharia elétrica, mecânica, física, são condições inerentes a existência desses empresários nas cidades.

São José do Rio Preto é também um município que integra o Sistema Paulista de Parques Tecnológicos. No entanto, esse novo sistema técnico ainda não se consolidou de forma definitiva. Sua realização, aliás, não conta com um órgão gestor responsável, como em Ribeirão Preto, e seu processo se desenvolve a partir da própria secretaria de planejamento municipal.

O Parque compreende um projeto ligado à "sustentabilidade", isto é, uma estação experimental de atividades de pesquisa e desenvolvimento tecnológico, voltadas para a área da saúde com processos corretos ambientalmente. 0 projeto segue se beneficiando das instituições municipais, como a plano de manejo, o zoneamento será realizado com a UNESP, onde argumentase sobre a proximidade física que permite a troca de conhecimento.

Com isso, querem criar uma cultura de pesquisa, de trabalho científico regionalmente, elevando a categoria da cidade no sistema urbano atual. As ações do programa vêm sendo discutidas e amadurecidas com os diferentes representantes de entidades, públicas e privadas, da cidade, que participam de um conselho gestor específico do projeto. 
Enquanto isso, a Secretaria de Desenvolvimento do Estado de São Paulo viabiliza as soluções de infraestutura, recursos humanos, para atrair investimentos das empresas locais e outras intensivas em conhecimento e desenvolvimento tecnológico.

Cabe dizer que São José do Rio Preto possui uma tradição de desenvolvimento industrial baseada em distritos, manifesta pela existência de uma variedade de mini-distritos com micro e pequenas empresas de diferentes ramos produtivos.

Nos anos 1970, quando as modernizações sob novas bases técnocientíficas e informacionais dão atenção para aumentar o crescimento econômico do país a partir da desconcentração industrial, algumas cidades do interior de São Paulo vieram conhecer um dinamismo econômico permitido pela criação dos distritos industriais.

Àquela época, São José do Rio Preto identificou na cidade um grande número de pequenas firmas e, com isso, empreendeu sua política industrial, adaptando-a a essa realidade. Essa parece ser a tradição do planejamento na cidade, onde há pequenos distritos industriais espalhados por várias áreas do município.

Reconhecer o empenho do Estado para promover o gasto privado em inovação, assim como coordenar redes de cooperação entre empresas, instituições de pesquisa e outras entidades públicas e privadas, é testemunhar a nova natureza cooperativa que se impõe às novas formas do planejamento pelos novos conteúdos da cientificização do trabalho e do processo de informatização do território.

Por outro lado, a inovação, enquanto é intrínseca a esse modelo produtivo técnico-científico na dinâmica das empresas e importante medida das dinâmicas gerais ligadas à globalização, parece mostrar-se, ela mesma, como categoria importada.

A empresa brasileira não inova, é o que diz a literatura empenhada em diagnosticar o ramo dos equipamentos médicos. Uma inovação que serve ao funcionamento do sistemismo do nosso tempo parece não querer incluir o homem como indivíduo que concebe objetos, cria técnicas.

Essa realidade imbuída de uma concepção erigida como modelo, entretanto, não se deve às individualidades, senão à própria formação socioespacial brasileira. E é ela mesma que sustenta a 
necessidade, mas do que a escolha, de que nossos produtos para a saúde estejam prenhes de criatividade, inventividade, imitações, adaptações, combinações as mais diversas.

De outra maneira, Zoaoual (2008) assinala que toda inovação é situada e logo reinterpretada em certos casos, ou rejeitada como tal. Assevera que é o sítio de pertencimento que fornece o enraizamento à pessoa e à síntese entre as singularidades próprias a sua visão de mundo e à mudança técnica que chega de fora. E escreve:

"Os mecanismos de evolução e de adoção da mudança e da inovação não são uniformes. Mudam em função dos sítios e da dinâmica dos mesmos. Isso constitui um problema insuperável para o pensamento globalizante.” (Zaoual, 2006:69)

Pois são as estruturas sociais que impedem a generalização das inovações, ensina Santos (1979). E parece que atualmente é em seu proveito que as modernizações correspondem tanto a maiores diferenciações dos lugares, quanto maior será a complexização dos circuitos da economia urbana.

As empresas produtoras de equipamentos médicos vêm tendo que intensificar seus esforços internos em pesquisa e desenvolvimento, assim como buscar fontes externas de conhecimento tecnológico. Contudo, em Ribeirão Preto, são assoladas por uma aceleração das exigências à própria sobrevivência.

Em função do ritmo que se impôs sobre a cidade para inserir a produção de equipamentos médicos na atual dinâmica global, o SEBRAE em Ribeirão Preto representa um papel relevante na criação de condições basilares.

Então, por meio de cursos de capacitação tecnológica, como para a certificação de seus produtos, e cursos de gestão, como para se inserirem noutros mercados, o SEBRAE instrui os empresários a melhorarem suas capacidades de organização.

O SEBRAE também se mostrou de grande relevância na criação do que chamaram de uma "cultura de cooperação", dado que agora muitas empresas deveriam parar de se tratar como concorrentes para ingressar um projeto coletivo de transformação da região numa referência produtos médico-hospitalares. 
Por ser o município paulista que, depois de São Paulo, mais produz equipamentos médicos no país, e estar sob o foco dos programas de desenvolvimento do governo federal e estadual, Ribeirão Preto revelou as modernizações normativas como principal fator de diferenciação dos circuitos da economia urbana ligados aos equipamentos médicos.

Já em Campinas, a economia urbana para a saúde é menos convergente aos interesses específicos dos equipamentos médicos, mas sim à tecnologia da informação. Nesse sentido, quando encontramos um fabricante sem as certificações necessárias, isso não se apresentou como um problema urgente à sua sobrevivência.

Apesar da legislação que recai sobre seu produto ser mais branda, no sentido de que não se trata de um equipamento de procedimento invasivo, a fabricação de seus lasers e chapas funciona às escusas, sem autorização devida. Mas ainda assim possui clientes em diferentes lugares do país.

Isso porque, tendo formação em física e exercido atividade profissional na área nuclear, esse fabricante possui a capacidade de fazer aparelhos de laser usados para marcar o ponto exato do tratamento médico, assim como as chapas e a máquina que faz as chapas para proteger o restante do corpo da radiação provinda dos procedimentos.

Como tais produtos, quando importados, são de alto custo para os estabelecimentos de saúde de menor capacidade financeira, sua imitação se torna uma demanda. Perguntado sobre a crescente modernização dos aparelhos e o acoplamento desses marcadores ao próprio objeto, o fabricante disse que vende para muitos lugares, onde essas tecnologias modernas não chegaram.

Certamente não queremos com isso legitimar o que é comumente chamado de pirataria, ou qualquer objeto que saia da conformidade técnica exigida pelo critério da segurança dos pacientes. Mas sim oferecer o que observamos, no sentido de que os limites normativos desenham as possibilidades, enquanto o território vivo parece permitir oportunidades a diferentes agentes.

Campinas, por ser um centro de tecnologia da informação e densa urbanização, revelou a existência de muitos fabricantes beneficiados antes e hoje, pelas universidades, institutos de 
pesquisa, assim como incubadoras de empresas que a cidade abriga.

No entanto, deparamos com uma quantidade de empresas que combinam diferentes formas de produzir serviços sofisticados ligados aos equipamentos médico-hospitalares, como a manutenção por meio da representação ou assistência técnica. Nessa complementaridade, encontramos ainda muitos agentes que comercializam produtos de outras empresas, nacionais ou não, grandes ou menores.

Em São José do Rio Preto, pudemos observar a perspectiva do Parque de Biotecnologia e de fabricantes de aparelhos de alta tecnologia, mas, assim como Campinas e Ribeirão Preto, encontramos muitas atividades cujo trabalho está vinculado aos serviços que os objetos médicos, de diferentes idades, demandam.

Nesse termo, a diferença entre as duas situações geográficas, se é que cabe dizer dessa forma, é que em São José do Rio Preto as atividades de manutenção, de um modo geral, pareceram de um caráter mais residual, sendo de enorme importância para as cidades vizinhas.

Trataremos essas complementaridades regionais com mais cuidado adiante, mas vale dizer já que tal fenômeno não parece responder apenas às demandas dadas pela hierarquia do sistema de saúde. A própria modernização por que passam os serviços de saúde desses municípios centrais estabelece a prevalência de manutenções mais qualificadas.

\subsection{0 papel das normas na obsolescência das formas de trabalho}

Vimos que as técnicas se dão como famílias, isto é, verdadeiros sistemas. A chegada da técnica da informação, por meio da cibernética, da informática, da eletrônica, que um novo sistema técnico é assegurado e, pela primeira vez na história, envolve o planeta como um todo.

As tecnologias médicas modernas são representativas desse novo tempo. O momento em que a emergência do mercado global se vale de um sistema de técnicas informacionais, a produção da saúde é também marcada pela comunicação entre as diversas técnicas e atesta um sistema invasor, dominante quanto ao uso hegemônico. 
Base do fenômeno da globalização, as unicidades das técnicas, da informação e do dinheiro (Santos, 1996) transformam os conteúdos dos lugares, enquanto os agregados de ciência, tecnologia e informação na medicina são expressões e motores das unicidades contemporâneas. São grandes corporações que dominam a produção desses objetos médicos modernos.

Da mesma forma, a organização dos serviços de saúde revela uma das manifestações desse novo subsistema hegemônico. Podemos mencionar a tendência à telemedicina, isto é, a realização de procedimentos diagnósticos e terapêuticos à distância, as consultas e orientações, a educação médica continuada, videoconferências, utilizando cabos e fibras óticas ou via satélite.

Para Ramires (2007:181), “não é difícil prever que, no futuro, existirá um limitado número de centros de telemedicina que deverão coincidir com os grandes centros líderes na produção do conhecimento e tecnologia médica”.

Mesmo sem apontar a telemedicina como discurso que busca reduzir custos e desigualdades no acesso à saúde, ou adentrar o debate que responsabiliza a criação desses ambientes de telesaúde como obstáculo à aplicação de investimentos em serviços locais, novas ${ }^{50}$ formas de obter saúde são reveladoras do caráter sistêmico das técnicas recentes.

Nessa mesma tendência, há hoje uma área nova dentro do ramo dos equipamentos, que são os equipamentos individuais de monitoração a distância. Tais mercados vêm ganhando proporções para o acompanhamento de pacientes pós-cirurgias e também idosos. Esse processo se revela ao lado do empenho dos hospitais em diminuir as custos com internações.

0 conhecimento instantâneo do acontecer do outro é o que Santos (1996) chamou de convergência dos momentos. Como temos visto, não estamos nos referindo à simples organização do sistema de saúde, ou de um apoio individual, mas sim a uma

${ }_{50}$ Também mencionamos outras tendências modernas na saúde: a existência de softwares que servem à leitura precisa em tempo real do que o paciente necessita numa mesa cirúrgica; os arquivos digitais individuais que permitem ao paciente ter organizado seu histórico clínico; o gerenciamento integrado do sistema de equipamentos médicos de um hospital ou de uma sala de procedimentos médicos; a rede online de diagnóstico por imagem que permite conectar unidades de saúde a partir de uma central onde se concentram médicos para a emissão de laudos. 
história comandada pelos atores hegemônicos, que são os agentes desse tempo real.

A interdependência que hoje põe todos os lugares incluídos num mesmo sistema global de ralações, podendo ser comunicado a qualquer outro de modo simultâneo o acontecer de cada lugar, é reveladora do privilégio do uso do tempo por um número reduzido de agentes poderosos. A informação como a energia que impregna as ações contemporâneas mostra de que modo esses agentes globais desfrutam da exclusividade na produção e difusão de uma certa informação para produzir e consumir saúde moderna.

Nesse sentido, tais empresas, como a Siemens, GE Electric, a Philips - representativas desse subsistema hegemônico, cujo poder de ação se realiza também no território nacional - são determinantes na produção das unicidades, como autores de um discurso ideológico e como agentes no comando de uma fluidez efetiva.

Se olhamos para a técnica médica em si, vemos sua eficiência para a saúde, entretanto sua existência histórica não permite tomá-la em absoluto, pois a técnica é tal como é usada pelo homem. Daí que a seletividade como princípio de realização das modernizações mostra que a medicina integra um processo de hierarquização entre as pessoas, as coisas e os lugares.

o trabalho que se torna, a cada dia, mais e mais trabalho científico, compreende um amplo processo em que o território se informatiza. 0 tempo unificado pelo uso do mesmo momento a partir de múltiplos lugares revela um planeta informado, para servir aos interesses de alguns atores hegemônicos.

A unicidade do motor, então, revela-se pelo processo da produção e como resultado da competitividade entre essas grandes empresas. Santos (1996) é quem nos apresenta esse processo como a emergência de uma mais-valia agora universal, que se impõe como um dado empírico e objetivo do acontecer dos lugares.

Em sua versão contemporânea, a tecnificação da medicina se pôs ao serviço de uma produção globalizada, onde não estamos longe de reconhecer que, a despeito da saúde das populações, é a busca desenfreada do lucro e dos elementos capazes de permiti-lo o que conta. 
Os estabelecimentos de saúde, enquanto representantes de interesses particulares, buscam aumentar a produtividade de atendimentos médicos por meio da incorporação de tecnologias sofisticadas. 0 conforto ao paciente, a maior definição para auxiliar os diagnósticos e tratamentos são benefícios que acompanham o aumento da velocidade dos procedimentos médicos.

É inegável que essa rapidez na obtenção de resultados termina por beneficiar a vida, que é sempre a de cada paciente, mas revela, da mesma forma, o mecanismo de modernização como meio de aumentar o número de exames e alcançar uma produtividade econômica através da serventia médica.

Quando se trata da sobrevivência ou mesmo do aumento da competitividade de alguns estabelecimentos de saúde ${ }^{51}$, os planos de saúde são elementos relevantes no entendimento dessa dinâmica econômica. A modernização, empenhada pelos serviços de saúde como recurso econômico, mostra a saúde enquanto consumo e a ampliação do uso dessa nova base técnica moderna.

Para Silveira (2007), essa expansão da constituição e uso dos objetos e ações representativas de nossa época revela a realidade complexa e multifacetada da metrópole.

"Não é surpreendente, então, que tais formas e nexos estejam presentes entre os pobres, nas divisões territoriais do trabalho que permitem sua sobrevivência, nas suas formas de consumo, nas relações de dependência, subordinação e verticalidade com os atores hegemônicos, mas igualmente nas relações horizontais que perfazem sua existência” (Silveira, 2007:2)

\footnotetext{
${ }_{51}$ A exemplo, dois hospitais privados do Grande Recife (PE) e outros dois no interior do Pernambuco deixaram de atender pelo Sistema Único de Saúde, tirando a disponibilidade de 400 leitos do sistema publico na região. Dos Santos, diretor de um desses estabelecimentos, numa declaração revelada pela Folha de São Paulo, em 23 de outubro de 2009, justifica ao dizer: "Somos um hospital privado e temos contas a pagar. Devo $\mathrm{R} \$ 5$ milhões em impostos. Essa tabela do SUS é ridícula, estamos tentando sobreviver". Nessa direção, o Ministério da Saúde reconhece que não é possível comparar a remuneração dos planos de saúde com a do sistema único de saúde, por isso vem adotando o que acredita serem medidas para que a diminuição dos leitos públicos não represente desassistência médica, como o reajuste da tabela do SUS, mas, sobretudo, como já mencionamos, a melhoria da gestão dos hospitais públicos, com as Organizações Sociais, e a relação preferencial com hospitais filantrópicos. Alguns representantes governamentais alegam o subfinanciamento do SUS como principal causa desses entraves, outros dizem que o fato de hospitais passarem a fazer procedimentos de maior complexidade e que os de menor complexidade sejam resolvidos em ambulatórios, isto é, sem hospitalização, é uma tendência mundial. Para nós ambos são realidades, parte de um mesmo processo.
} 
Os sistemas técnicos contemporâneos possuem uma qualidade inexistente em relação ao período industrial. Por serem divisíveis e flexíveis (Gaudin, 1978; Santos, 1996), permitem que um pequeno agente faça uso das mesmas variáveis modernas, mas, por necessidade ou criatividade, realize um trabalho próprio do meio a que pertence.

Atividades de reparação de equipamentos à saúde, nascidas no contexto urbano das medicinas modernas, não podem ser explicadas unicamente pela economia hegemônica. Da mesma forma, o consumo é ação prenhe de informação. Embora imbuída de uma natureza ideológica, a informação permite que pequenos agentes locais se valham da publicidade de outros para encontrar seus mercados.

É o caso de pequenos fabricantes de móveis médicohospitalares que, pela visita aos sítios eletrônicos de empresas hegemônicas ou seus concorrentes, reconhecem as tendências de mercado a serem acompanhadas. Nesse sentido, o computador e a internet se revelaram instrumentos de trabalho de extrema importância para a dinâmica dos fabricantes de equipamentos médicos.

A informação globalizada veiculada em meio banal termina por servir aos diferentes consumos. Do mesmo modo, o computador facilita a negociação com os fornecedores de insumos, assim como autoriza clientes longínquos. Tais objetos são parte da base material indispensáveis aos usos e alcances de escalas diversas.

A internet, como meio facilitador das trocas, se abre como oportunidade aos pequenos produtores. Entretanto, à medida que alguns prestadores de serviços de saúde se beneficiam desse meio para importar produtos sem controle adequado, torna-se ainda mais denso o discurso sobre produtos "falsificados".

Ao observarmos a interdependência atual dos eventos a partir dos diferentes graus de capital, tecnologia e organização dos agentes, vemos que os circuitos da economia urbana são expressão da convivência de diferentes divisões territoriais do trabalho, que se realizam pela solidariedade dos acontecimentos contemporâneos.

Advindos da unicidade técnica, da convergência da informação e da lógica do dinheiro à escala do planeta, os circuitos da economia urbana são resultado e condição da interdependência obrigatória entre as diferentes formas de trabalho. 
Resultado direto da modernização tecnológica, o circuito superior, representado, sobretudo, pelos monopólios e oligopólios, alarga, a cada dia, seus circuitos espaciais de produção e círculos de cooperação. Sinônimo de uma divisão do trabalho hegemônica ${ }^{52}$, sua interferência sobre as demais atividades é determinante.

Resultado indireto do mesmo fenômeno de modernização tecnológica, o circuito inferior está em modificação permanente. Suas atividades, como mostra Montenegro (2006), representam conteúdos próprios do meio geográfico no qual se localizam.

Fruto de uma demanda de emprego e serviços não atendidos pela moderna economia urbana, o circuito inferior responde a uma ordem local e nem por isso deixa de complementar ou subordinarse a outros circuitos produtivos.

A solidariedade desse novo tempo da globalização depende ou independe da vizinhança, e como nos mostra Silveira (2004) é pela contiguidade que vemos a interrelação dos circuitos da economia urbana. Santos (1996:132) é quem define esse acontecer solidário como "a realização compulsória de tarefas comuns, mesmo que o projeto não seja comum”.

Santos (1996) caracteriza esse acontecer dos lugares a partir da diferenciação analítica de três tipos. Daí escreve:

"Esse acontecer solidário, malgrado todas as formas de diferença, entre pessoas, entre lugares, se apresenta sob três formas no território atual: um acontecer homólogo, um acontecer complementar e um acontecer hierárquico.” (Santos, 1996:132)

A extensão da ação de pequenos agentes será, pois, não apenas resultado do ato de império (Silveira, 2004b) que vem funcionalizar a divisão do trabalho hegemônico. Mas também racionalidades situadas, pois o aumento da divisão do trabalho se torna condição às interdependências entre diferentes temporalidades de alcances diversos.

\footnotetext{
${ }^{52}$ Como observa Silveira (2007), "graças à relevância da informação e da finança, seus atores não são apenas grandes indústrias e bancos, mas corporações globais multisetoriais, empresas de produção e serviços de alta tecnologia, empresas de consultoria e outras firmas produtoras de informação, grandes firmas de entertainment e poderosos atores do sistema financeiro, como fundos de investimentos, fundos de pensão e outros."
} 
Nessa direção, Santos (1988:59) assevera que o sistema temporal comandado pelo subsistema hegemônico supõe uma convivência com os outros muitos subsistemas, sendo o resultado aquele em que "cada país é territorialmente definido pelo não pelo subsistema hegemônico, mas por combinações as mais diversas”.

Daí também poder dizer que os circuitos da economia urbana não se definem apenas pelas atividades de produção, tampouco de um ramo produtivo em particular. Pois é a cidade a totalidade que se revela como abrigo de um permanente movimento de cooperação e conflito, expresso por diferentes divisões territoriais do trabalho.

"Quanto maiores e mais populosas as cidades, mais capazes são de abrigar uma extensa gama de atividades e de conter uma lista maior de profissões (Santos e Silveira, 2001), autorizando uma maior complexidade dos circuitos da economia urbana." (Silveira, 2004:3)

Diante do novo sistema urbano marcado pela extensa diferenciação e complexificação, cada uma das cidades visitadas fez atentar por suas funções mais modernas, isto é, aquelas que orientam sua inserção na atual divisão do territorial hegemônica do trabalho, e aquelas funções que ali coexistem, ainda que não sejam modernas.

Com atenção para os diferentes níveis de relação com o meio construído e o mercado, os circuitos da economia urbana ligado aos equipamentos médicos se pronunciaram, em cada cidade, por um conjunto solidário e contraditório de divisões do trabalho.

Com vistas à tamanha diversidade nessas cidades, nossa interpretação foi enriquecida pelas narrativas dos entrevistados. Estas permitiram apreender um enredo constituído de elementos menos visíveis da economia urbana.

Sendo a cidade essa totalidade integral das diferenças, o que se pôs foi também uma questão de método. Sartre (1960) em sua Crítica à Razão Dialética nos orienta ao escrever:

"Não é a diversidade de interesses que faz nascer os conflitos, mas são os conflitos que produzem o interesse, na medida em que a matéria trabalhada se impõe aos grupos em luta como realidade 
independente pela impotência provisória que nasce de sua relação de força." (Sartre, 2002)

Para então reconhecer a existência de um circuito superior marginal vinculado aos equipamentos médicos, procuramos desvendar alguns mecanismos dos atores hegemônicos na criação daquilo que se torna escassez aos outros agentes. Pois, enfim, os atores não têm igual força para realizar as possibilidades do período.

0 endurecimento dos objetos médicos modernos se mostra por técnicas duras e condicionamentos ao uso. A técnica é criadora de normas, ensina Silveira (2000:216). A validade mercantil das tecnologias à saúde passa a requerer garantias, que devem responder às trajetórias programadas. Vale enfatizar que a geografia que dota alguns lugares de uma carga de racionalidade - como o tratamento político da saúde em termos de ciência e tecnologia - é mediada pelas normas políticas de cada Estadonação.

Há uma dupla produção de ordem, apura Santos (1996:238), aquela produto da existência técnica de cada objeto e aquela que resulta de sua disposição, de seu arranjo. E acrescenta: "Em ambos os casos, é uma ordem que arrasta outros objetos e ações, um resultado da própria sistematicidade das técnicas”.

Nesse sentido, criar novas condições de cooperação e interdependência funcional implica um processo modernizador em que é maior o peso dos fatores organizacionais. A organização é aqui entendida como normas de ação (Santos 1996:241).

Defrontamos, outrossim, com um verdadeiro endurecimento organizacional, como chamou Santos (1996:144) essa indispensabilidade das técnicas de ação para alcançar a produtividade que se pretende.

Desse modo, torna-se evidente que a globalização como ápice da internacionalização do mundo capitalista está constituída não apenas pelo estado das técnicas, mas, pelo estado da política, sendo inseparável daquele.

A produção da globalização pelas unicidades, parece, elevou a competitividade à escala do planeta como um caminho inelutável. A partir de um comportamento padronizado pelas normas, a 
obediência à racionalidade hegemônica e os desafios ao desenvolvimento nacional aparecem como uma e a mesma questão.

À medida que a organização se instala como demanda da economia moderna, parece tornar-se um elemento motor da diferenciação dos circuitos de economia urbana. Igualmente, o nível de organização adquire papel na definição do circuito superior marginal, na medida em que distingue empresas mais e menos poderosas.

As unicidades, nesse sentido, mostram que os acréscimos de tecnociência, informação e finanças nos conteúdos da medicina e suas áreas afins transformam a saúde em um elemento no processo de produção da globalização.

Para observar os modos de regulação no período técnicocientífico e informacional, Silveira (1997) nos ensina reconhecer normas técnicas, normas organizacionais e normas políticas.

As normas técnicas são aquelas criadas na concepção mesma do objeto. No caso dos equipamentos médico-hospitalares, as normas técnicas são originadas nos Estados Unidos ${ }^{53}$ (Braga e Silva, 2001:22), base mundial dessa indústria.

Também definidas como técnicas de constituição e de uso (Silveira, 2000:216), as normas técnicas "são, progressivamente, ancoradas nos graus diversos de informação”. Daí que o dado científico dos equipamentos médicos modernos mobiliza um processo de cientifização do trabalho, cuja repercussão está para além desse âmbito técnico da norma.

Nesse sentido, podemos dizer que a porção marginal do circuito superior vinculado a esses objetos médicos cresce e se torna mais complexa, pois, os novos patamares científicos multiplicam as possibilidades de um acontecer hierárquico, subordinado às tarefas confiadas pelo circuito superior puro.

É esse o caso de muitas atividades que realizam a manutenção em equipamentos sofisticados. Campinas, por ser uma metrópole e, relativamente às outras duas cidades, possuir maior densidade da

${ }_{53}$ É também nos Estados Unidos que se originam os parâmetros da saúde, dada a fundamentação científica dessa indústria e o desenvolvimento das soluções determinantes no campo médico. 
tecnociência e informação, mostrou haver um mercado amplo e mais acessível para as atividades relacionadas aos equipamentos.

Entretanto, o ritmo das modernizações tecnológicas dos objetos médicos revela que "as normas técnicas serem substituídas por outras tão aceleradamente quanto os objetos técnicos se sucedem e se tornam obsoletos” (Silveira, 1997:36) produz uma aceleração normativa incessante.

De algum modo, o crescimento do consumo de modernas tecnologias médicas que não produzimos no país e estas, ao se apresentarem como família de técnicas, pode ser explicado também por um processo de oligopolização desempenhado pelas normas técnicas.

Já as normas organizacionais são "responsáveis pela regulação das formas de utilização dos novos objetos no processo do trabalho" (Silveira, 1997:37). Podemos ainda entendê-las como normas de difusão dos sistemas técnicos (Silveira, 2000).

As normas de organização, empreendidas pelas instituições públicas, nacionais e internacionais, e empresas privadas, buscam criar um âmbito de fluidez efetiva com a presença de novos sistemas técnicos, instalados sobre os preexistentes.

Nessa direção, Bicudo (2006), em seu estudo sobre a indústria farmacêutica no país, mostra a existência de um circuito superior marginal formado, em larga medida, pelo aparato normativo que regula a produção de medicamentos.

Com disposição para substituir o conjunto normativo vigente, a busca por eficiência de uso do território se reflete nas medidas organizacionais que surgem como forma de homogeneizar as diferentes razões locais.

De todo modo, tais normas podem significar benefícios, assim como obstáculos à produção e ao consumo, a depender da força de cada agente. Nesse sentido, diferentes velocidades são criadas ao mesmo tempo em que se compartimenta o território.

Em Ribeirão Preto, a promoção de uma acelerada conformação às regulamentações nacionais e internacionais ligadas à modernização do sistema produtivo de equipamentos médicos mostra não apenas oportunidades, mas a vulnerabilidade da produção nacional diante da velocidade das exigências normativas. 
Noutra vertente, o empenho à corrida pela certificação dos produtos nacionais e a facilitação tributária da importação de equipamentos modernos pelos serviços de saúde são a circularidade de um mesmo processo, onde a capitalização é a regra diante do imperativo à competitividade.

De modo geral, há um processo crescente em que o uso do território presume formas e conteúdos informacionais. Nesse sentido, a informação demandante para trabalhar os objetos e contida nos mesmos mostra um vetor de diferenciação entre os agentes.

Já mencionamos que cidades como Campinas, Ribeirão Preto e São José do Rio Preto revelaram-se como lugares em que a existência de cursos técnicos e superiores são condição à dinâmica econômica ligada aos equipamentos médicos. É nesse sentido que a modernização tecnológica e organizacional por que passam os equipamentos médicos hoje mostra um papel das normas na obsolescência das formas de trabalho.

Daí o circuito superior marginal vinculado a esses objetos se deixar reconhecer pelo que tem de funcional à economia moderna, assim como pelo comportamento residual de algumas atividades intersticiais na economia urbana. A incapacidade de se modernizar ao ritmo da época manifesta um universo de atividades hegemônicas e não-hegemônicas, as quais pudemos observar pelo alargamento do circuito superior marginal e sua natureza criadora de economia.

Equipamentos de pressão arterial não se tornaram obsoletos com a chegada dos digitais. Para muitos prestadores de serviços de saúde, a qualidade dos equipamentos analógicos é maior, mesmo porque ainda não há uma forma padronizada de calibração que garanta a precisão adequada para o uso médico-hospitalar.

Aqueles agentes que fazem a manutenção destes aparelhos continuam a fazer. Utilizando-se de insumos fornecidas por grandes empresas em São Paulo e estando suas atividades de consertos, calibrações, certificações sob a regulação da agencia de fiscalização, vimos que muitos são os hospitais e clínicas, públicas e privadas que se valem do serviço na região de Campinas.

Assim, à medida que alguns serviços de reparação de equipamentos mais modernos vêm exigir conhecimento científico e 
treinamento técnico, outros serviços ainda se mantêm, por um lado, pelo que permite a norma, mas, por outro, pelo que os lugares apresentam como demandas a serem satisfeitas.

Ainda, vale atentar para o fato de que a densidade de normas que hoje recai sobre os equipamentos médicos, como um processo acelerado de adequação às regras e padrões internacionais de certificação de produtos, revela da mesma forma o crescimento da chamada pirataria na área médica.

Isso não quer dizer a falta necessária de esterilização ou qualidade duvidosa de materiais e aparelhos, tampouco a fraude das embalagens originais com produtos sem procedência, mas sim, a relação entre os altos lucros possíveis quando descomprometidos com os altos gastos com a certificação.

Já as normas políticas, “abrangem as relações de cooperação e disputa entre o Estado e o mercado e contribuem, assim, para comandar o funcionamento dos sistemas de engenharia” (Silveira, 1997:39).

Podemos mencionar as reformas do Estado implementadas pela chamada desregulação como nova modernidade, ao lado da tendência à mudança da gestão dos hospitais públicos brasileiros, onde a crise $^{54}$ anunciada na década de 1990 sugeria a flexibilização administrativa dessas organizações a despeito da burocratização.

Enquanto fluxos transnacionais de capital são um dado do período, o Estado parece cooperar no propósito dessa nova engenharia organizacional do sistema capitalista. Entendidas também como normas de intencionalidade (Silveira, 2000), as atuais normas políticas relacionadas aos objetos médicos se mostraram uma forma moderna de organização que se impõe como solução de fluidez à escala planetária.

Nesse sentido, o ramo dos equipamentos médico-hospitalares no país está compreendido por uma densidade normativa (Silveira,

\footnotetext{
${ }_{54}$ "Limitada em sua capacidade operacional e processual em razão da baixa possibilidade de escolha do gestor; submetida em suas decisões aos controles administrativos formais e às formas difusas e externas de autoridade e influência" (Costa et al (2000:429) sustentaram os argumentos da crise da gestão pública hospitalar na década de 1990. "A falta de alternativas que ampliassem a capacidade dessas organizações responderem às novas demandas por qualidade e presteza no atendimento". Esse cenário, como explica Costa et al (2000), foi alterado pela difusão da agenda de flexibilização administrativa, cujo exemplo bem acabado no Estado de São Paulo é o modelo de contato de gestão entre a secretaria de saúde e as organizações sociais.
} 
1996). Veremos como algumas questões da saúde, enfrentadas no país pelo caráter técnico e científico que hoje a define, se embaraçam quanto à garantia do direito a esse bem coletivo.

o Estado, pensando fazer políticas gerais de benefício à nação como um todo, pratica políticas territoriais seletivas. Como revela o programa de especialização produtiva em Ribeirão Preto, uma maior espessura da divisão do trabalho se instala em alguns lugares, criando novos dinamismos, assim como novas fragmentações.

Nesse sentido, podemos falar de um caráter não apenas técnico, mas político da obsolescência das formas de trabalho. Para os atores que são todos aqueles que não chegam a medir sua eficiência pelos fins à competitividade, o território é um abrigo e não dispensa a idéia de nação, sinônimo para estes de Estado.

\subsection{Controvérsias das políticas públicas}

Como vimos, é dado que as lacunas da distribuição dos serviços de saúde estejam eventualmente relacionadas à natureza concentradora das tecnologias. No entanto, importa também lembrar que a densidade de hospitais nas regiões Sudeste e Sul do país precede à concepção do sistema de saúde universal.

0 território assim constituído desempenha sua inércia dinâmica ao projeto de equidade em saúde, assim como termina por constituir a base material sobre a qual o território é usado em benefício de novas concentrações dos serviços e das tecnologias médicas.

Nesse sentido, o território parece ser, ele mesmo, resistência à realização do acesso universal à saúde, pois sua estrutura operacional em níveis de complexidade termina por privilegiar um uso por parte dos agentes hegemônicos, cujo efeito são as polarizações já conhecidas.

É comum que as interpretações a respeito do acesso desigual aos serviços de saúde no Brasil privilegiem uma análise sobre o lugar de residência das populações e a distribuição dos estabelecimentos, usando variáveis como renda, sistema de transportes, entre outros. 
Entretanto, há mecanismos ainda mais complexos na realização do sistema único de saúde. Vimos alguns mecanismos que fazem com que o sistema público de saúde responda por uma lógica mercantil. Haverá outros que dizem respeito ao comportamento dos agentes produtivos e daremos atenção mais a frente.

Nesse sentido, pudemos observar que o território usado por uma economia segmentada é revelador de algumas controvérsias das políticas públicas que contribuem ao agravamento das desigualdades evidentes.

o Estado, por meio do serviço público de saúde, é comprador de serviços privados e termina por incentivar as modernizações e desigualdades. Por outro lado, o Estado é também comprador de produtos médicos para prestar o serviço público, nesse sentido, possui importante papel na dinâmica econômica dos equipamentos médicos.

Quando o que se pretende é o direito ao bem coletivo e o acesso universal ao sistema de saúde no país, veremos como questões estruturais se revelam quando temos, lado a lado, as ações do Estado na mediação dos interesses da nação e as ações hegemônicas da iniciativa privada.

Para que a política de saúde seja uma oportunidade concreta para refletir e servir às necessidades da nação, alguns paradoxos da relação entre a política social e a política econômica se tornam expressos pelo modo como o território é usado por uma diversidade de agentes com força desigual.

As políticas de ciência e tecnologia e as políticas de especialização dos lugares, atreladas aos interesses das políticas de saúde, são reveladoras de contradições expressas no movimento permanente que é o uso do território. o que torna a tarefa de compreensão ainda mais árdua.

Ainda que o mérito nacional de trazer à política de desenvolvimento o concílio com as demandas do sistema de saúde não deva ser obscurecido, propomos um olhar cuidadoso sobre a dinâmica da economia urbana, diante dos efeitos de tantas esferas modernizadoras.

Os circuitos da economia urbana são, portanto, um fundamento histórico e metodológico com o qual nos propomos internar a dinâmica de cooperação e conflito entre as diferentes divisões 
territoriais do trabalho. Estes respondem hoje por uma solidariedade, produto da organização à escala do planeta.

Diante da interdependência dos eventos, nosso esforço de interpretação reside sobre alguns lugares que nos permitiriam surpreender o movimento do modo como a produção e o consumo da saúde se fazem no contexto da especificidade da urbanização brasileira e seu processo recente.

Quando Santos (1996:96) nos ensina sobre a importância de distinguir a totalidade produzida e a totalidade em produção, sendo que as duas convivem no mesmo momento e nos mesmos lugares, parece apontar, sobretudo, para as oportunidades que os lugares representam à objetivação das possibilidades do mundo.

Nesse sentido, continua o autor (1996:271), esse espaço territorial que, localmente, age como norma é locus de um processo de totalização, mas, enquanto coisa acabada nos dá apenas uma cristalização do movimento, e não a própria vida.

Os serviços de saúde de referência nas respectivas regiões de Campinas, Ribeirão Preto e São José do Rio Preto, aparecem como efeito e condição dos processos de totalização relacionados aos novos conteúdos técnico-científicos e informacionais que, atualmente, definem a saúde e presidem a organização do espaço.

"Como os fatores de produção e as atividades relacionadas têm um lugar próprio no espaço a cada momento de evolução social, seguese que todos os fatores têm influência sobre a forma como o espaço se organiza, e sobre a urbanização.” (Santos, 2008:59)

É sob essa perspectiva do fenômeno técnico que queremos apontar as controvérsias das políticas públicas como observação sobre o território vivo, o território sendo usado, revelador de que o lugar tanto defronta o mundo quanto também o confronta, graças a sua ordem (Santos, 2008:166).

Nas cidades, a presença dos hospitais públicos e privados, clínicas e outros estabelecimentos de saúde empreende um papel sobre as demandas da produção e consumo de bens e serviços na região. E, com efeito, na caracterização dos circuitos da economia urbana relacionados à saúde.

Ainda que esse arsenal técnico e político esteja para fortalecer a indústria nacional de equipamentos médicos, a carência de uma visão capaz de contemplar as particularidades da 
urbanização brasileira tende a comprometer seus objetivos e eficiência política.

Nesse sentido, não admitir a segmentação da economia urbana e as diferentes atividades ligadas à produção e consumo da saúde, sendo este um desafio político na efetivação do chamado desenvolvimento nacional, termina por fazer com que os mecanismos de oligopolização da economia ganhem força no mercado interno.

o Estado é o principal comprador da produção nacional. Nesse sentido, os hospitais públicos, maiores demandantes de materiais de toda ordem, seriam os principais responsáveis por uma dinâmica entre os fornecedores de produtos médico-hospitalares.

Quando observamos a região concentrada por essa perspectiva, vemos também uma densidade e diversidade de divisões territoriais do trabalho que podem coexistir pelas próprias demandas diversificadas dos serviços de saúde.

Isso porque as funções hierárquicas e complementares da organização desses serviços permitem a coexistência entre técnicas de diferentes idades, pois, os objetos mais antigos não se tornam automaticamente obsoletos com a dinâmica das modernizações.

o território é, nesse sentido, uma norma que autoriza a existência de uma diversidade de demandas por equipamentos médicos, o que amplia nosso pensamento sobre o estímulo e a existência de formas de trabalho que convivem, apesar das diferenças de níveis de capital, tecnologia e organização.

Entretanto, sabemos, as formas de trabalho são permanentemente recriadas e, quando damos atenção às compras por parte dos hospitais, o movimento de totalização põe em relevo outros elementos na nossa análise.

Nesse sentido, quando tratamos a respeito de materiais de uso contínuo ou aparelhos que não são unitários, como tomógrafos, etc, ou seja, quando tratamos dos produtos que correspondem ao próprio perfil de menor complexidade tecnológica da produção nacional, os hospitais não favorecem esses pequenos fabricantes, que são a maioria no país.

Os hospitais são consumidores de grandes quantidades. Esse é, sem dúvida, um nexo da causalidade que cria dificuldade de 
acesso desses fabricantes ao mercado público, pois é pequena a escala de cada pequena firma nacional. Entretanto, algumas outras peculiaridades ajudam observar mais largamente a complexidade desse enredo revelado pela economia urbana.

Outro nexo pode ser definido pela relevância da circulação que, hoje, permite, mesmo a pequenos produtores, mercados longínquos. A terceirização da economia faz dos distribuidores logísticos um trabalho complementar indispensável quando 0 consumo se torna difuso no território nacional.

Esses distribuidores, a depender de seus tamanhos, medidos, sobretudo, pela capacidade de estoque, são verdadeiros atravessadores entre os fabricantes e os consumidores finais, os serviços de saúde. De tal modo que são eles que muitas vezes participam das licitações.

Noutro sentido, mas ainda nesse nexo que limita a oferta da produção direta dos fabricantes ao serviço público, os objetos representados pela atual unicidade da técnica se dão cada vez mais como grupos de técnicas. São subsistemas técnico-médicos que impedem que o produto seja comprado sem que com ele esteja atrelada uma família de técnicas.

Desse modo, os fabricantes capazes de grandes escalas de produção não costumam coincidir com os agentes produtivos nacionais. A participação nas licitações foi reveladora para observar alguns dos mecanismos de entraves a que estão sujeitos.

Os encargos e impostos elevados, a obrigatoriedade das certificações da produção, também declarada como determinante direta dos altos custos da produção das pequenas empresas, são elementos que os afastam das compras públicas, já que, ainda hoje, o preço é o critério determinante das licitações.

Da mesma maneira, a demora que há para a tramitação burocrática da realização do pagamento público ao pequeno fabricante faz parte desse desestímulo que tem o produtor nacional de encontrar, no comércio com os serviços públicos, um interesse ao negócio.

Mais um elemento desse pequeno círculo vicioso, podemos observar, é a crescente sistematização eletrônica dos pregões licitatórios, cuja organização exige uma dedicação tal que somente aqueles produtores que vêm na compra pública um mercado 
relevante especializam essa área na composição interna da própria empresa.

Vemos que a padronização desse sistema digital dos pregões termina por selecionar a participação de um grupo, ainda que aberto, de empresas, que vão criando habilidade e se especializando nas técnicas de ações que essa atualização das licitações propõe.

As compras públicas, de modo geral, tendem a beneficiar as empresas com maior escala de produção. Nesse sentido, quando essa realidade é problematizada pelas políticas e os órgãos gestores, as questões entre sistema produtivo nacional e serviço de saúde têm no seu centro a escala de produção nacional.

Contudo, esse tratamento não terá uma solução simples como um modelo a ser aplicado. Por exemplo, sabemos que os médicos, como aqueles que decidem sobre quais equipamentos e quando os adquirir, possuem preferências técnicas. Nesse sentido, há uma possibilidade de que as descrições das necessidades e virtualidades dos aparelhos técnicas podem significar certo direcionamento das licitações.

Aliás, quando o equipamento não possui correspondente na produção nacional, a importação é facilitada. Por um lado, entende-se a importância dessa regulação, por outro, vemos a lacuna que pode significar a origem da demanda por técnicas médicas mais e mais modernas.

Nesse sentido, ainda sobre o poder de compra do Estado, quando mencionamos os equipamentos mais modernos, grandes objetos como os ultra-sons, tomógrafos, ressonâncias magnéticas, até mesmo raios-x digitais etc, precisamos apontar o papel da modernização dos hospitais filantrópicos.

o tratamento tributário diferenciado de que usufruem, inclusive quando é feita a aquisição de equipamentos, por sua vez, muitas vezes exagerada em relação às necessidades dos pacientes, termina por beneficiar uma aceleração das modernizações em saúde.

Isso porque a preferência dessas entidades por uma complexidade médica altamente sofisticada representa também rendimento e uma vantagem competitiva em relação a outros hospitais, o que não parece um dado menos importante na inchação 
das demandas técnicas e políticas que acompanham a modernização médica.

Tal fenômeno imprime um ritmo que se verifica pelas disputas no mercado interno. E a velocidade parece se tornar o principal repressor de muitos pequenos empresários, pois é acelerada a obsolescência da capacidade produtiva nacional.

Com isso é alterado também o ritmo daquela regulação que vê urgência na certificação da qualidade dos produtos nacionais, de modo a não perder pontos em competitividade internacional, dado que é essa mesma a razão do imperativo que empurra à importação.

No país, o aumento da demanda por saúde e da oferta de serviços tem-se revelado em expansão dos serviços de saúde privados. Pois, enquanto as reformas políticas obrigam uma contenção no volume de gastos públicos, os recursos advindos de seguros e convênios médicos aumentam a espessura e segmentação do mercado privado.

Nesse contexto em que cresce e se diversifica um vasto número de clínicas e outros serviços de saúde particulares no país, acrescentamos que o próprio sistema público é demandante de serviços de saúde privados e, por meio deles, realiza seus procedimentos.

A iniciativa privada tem exercido papel na dinâmica econômica da indústria nacional de equipamentos médico-hospitalares nacional. Esse caminho, de algum modo, parece evidenciar os hibridismos das ações públicas e privadas e algumas contradições explícitas entre o poder de compra do Estado e as disputas do mercado interno.

Nesse sentido, parece que estamos autorizados a entender que cada estabelecimento de saúde, sobretudo os hospitais, revela um sistema técnico-médico particular. E, tendo certa autonomia sobre a decisão de suas compras, o sistema de saúde brasileiro, que prevê o acesso universal, torna-se um funcionamento dissintônico.

Sabe-se que, por vezes, a tecnologia mais moderna não é necessariamente a melhor opção clínica para algumas especialidades médicas. E que para a aquisição de equipamentos novos há falta de planejamento adequado ao perfil epidemiológico das regiões. 
Também há concentração de um mesmo tipo de equipamento na mesma região. E essa situação é ainda agravada pelo fato do Estado possuir limitado conhecimento da quantidade e qualidade do parque de equipamentos médicos do país (Calil, 2001).

Evidências disso são as estimativas do próprio Ministério da Saúde, que denunciavam, em 2002, a má alocação dos equipamentos médicos no país. 0 parque estava $40 \%$ subutilizado ou inoperante em função de aquisições inadequadas, de qualidade insatisfatória, uso indevido, gerência e manutenção deficiente (ABDI, 2006:203).

Considerando a existência de um excesso e falta de objetos desarticulados com as demandas de saúde da população, e desperdícios desarticulados das demandas de trabalho nas regiões, podemos considerar que a lógica de modernização dos equipamentos médicos está enviesada de interesses que não estão em acordo com a origem das nossas demandas.

Nesse sentido, a subordinação de um grande número de agentes econômicos pode ser medida não apenas pela distância tecnológica, mas sim pelo modo como as diferentes empresas nacionais são integradas num circuito de produção, ainda, capaz de servir as necessidades da nação.

Enquanto aumenta o consumo de saúde e, com ele, as importações de equipamentos médicos modernos, a indústria nacional vem ganhando estímulos e melhorando sua participação no mercado internacional.

Isso não quer dizer que haja uma integração econômica maior da produção aos lugares e região.

"Os indicadores de consumo crescem sem que alcancemos o desenvolvimento, pois não se trata só de aumentar o consumo senão também de cuidar que as formas de produção de todos os tamanhos e todas as velocidades possam ter seu lugar." (Silveira, 2007:21)

Nessa esteira desse processo de cientificização do trabalho ligado às atividades para a saúde, podemos observar o que assevera Silveira (2007:21) quando diz que muitas vezes em que se fala em mercado interno, o que se realiza na realidade é uma profunda internacionalização do consumo interno. 
o poder de compra do Estado que, em grande medida, serviria para beneficiar o mercado interno precisa transpor entraves para que se faça valer. As propostas políticas que mencionamos em curso trazem o reconhecimento de que é preciso estimular a produção daqueles produtos que servem ao sistema de saúde.

Essa articulação entre o fortalecimento da indústria nacional e o Estado, como garantia de mercado a alguns produtos de ordem estratégica, explicita alguns limites quando a vemos pela dinâmica do território usado.

A concepção de que há uma vulnerabilidade do sistema de saúde por sua dependência de alguns monopólios e outros produtos médicos importados pôs em marcha um interesse do Estado de enfrentar a questão por uma política de inovação, inserindo a saúde num novo contexto nacional.

Embora o empenho nos métodos esteja direcionando seus objetivos, ou seja, estimular a cooperação entre universidadeempresa e usar a regulação, ambos como mecanismo para elevar a capacidade tecnológica da produção nacional, o poder de compra do Estado nos pareceu ainda pouco articulado.

A lista à qual se amarram alguns produtos como estratégicos para o uso desse poder de compra não é fixa, mas revista pelo fórum do grupo permanente do complexo industrial da saúde $(\text { GECIS })^{55}$. Por se tratar de casos e produtos específicos nesse desenho das vulnerabilidades do sistema de saúde em relação à força de algumas empresas, essa lista é cada vez mais restrita, pois os produtos são criteriosamente escolhidos, como exceções.

\footnotetext{
${ }_{55}$ A Portaria n.978 de 16 de maio de 2008, dispõe sobre a lista de produtos estratégicos, no âmbito do Sistema Único de Saúde, com a finalidade de colaborar com o desenvolvimento do Complexo Industrial da Saúde e institui a Comissão para Revisão e Atualização. Na ocasião, em 2008, a referida lista continha: Aparelho de Anestesia, com suporte (carrinho); Aparelho de Ultra Som Diagnóstico; Aparelho de Mamografia; Aparelho de Endoscopia, em suas mais variadas aplicações; Aparelho de RX: (Móvel e Fixo) e odontológico; Cateteres eletrofisiológicos; Cateteres Angiográficos de uso em radiologia; Marcapasso Implantáveis; Cardioversor/Desfibrilador; Indutores, bainhas e agulhas para estudos e procedimentos eletrofisiológicos; Stents: sem fármacos e com fármacos; Desfibrilador Externo Automático DEA; Eletrocardiógrafos: portáteis ou de mesa; Equipamentos de Hemodiálise e acessórios; Freezer/Conservador de Amostras, Sangue, Vacinas; Endopróteses vasculares; Filtro de veia cava; Oxímetro de Pulso: portátil ou de mesa; Monitoração: monitores cardíacos e Monitores Multiparâmetros; Ventilador Pulmonar; Implantes Ortopédicos; Equipamentos para diagnóstico in vitro e in vivo; Sensores de Oximetria e Capnografia; Receptores/detectores digitais para geração de imagem (Radiologia Digital)
} 
Ainda que seja uma ação de importância extrema, quando observamos o Estado como o grande comprador de equipamentos médicos e dinamizador da economia urbana, essa informação se dilui pela interdependência com outros dilemas que apontaremos a seguir.

A verticalidade do uso do território brasileiro como um mercado, quando vemos essas grandes empresas, como a Siemens, a GE, e a estrutura de seus investimentos em pesquisa e desenvolvimento, parece tornar implacável a fragilidade das nossas políticas.

Diante da atual interdependência dos eventos, a saúde moderna presidida pela inovação constante, não passa de um veículo que, por meio do próprio sistema de saúde, envolve muitos outros agentes em relações de dependência e subordinação.

Enquanto isso, os serviços de saúde dominados por essa modificação permanente dos objetos e das ações não passam de um suporte às demandas que não são próprias da população, mas, antes, dos agentes hegemônicos.

Um dos mecanismos de ação hegemônica que, inclusive, já tratamos antes, é a proximidade de tais agentes com o sistema financeiro, sendo este um meio pelo qual se amplia a possibilidade da aquisição de seus produtos pela oferta de financiamentos próprios.

Ainda mais, o mecanismo mais recente é a venda de produtos com serviços pós-venda integrados. Isso alonga a vida útil desse verdadeiro oligopsônio na relação entre os serviços de saúde e os agentes hegemônicos. Os hospitais são grandes cúmplices desse processo.

Contradição ainda relevante mencionar é o mecanismo de estímulo à produção nacional por meio das subvenções econômicas. Carecendo de adequada amarra ao poder de compra do Estado, os recursos públicos são gastos com projetos que, a princípio, são significativos para o país, mas que sem esse elo, não recompensa o próprio Estado do investimento feito.

A elevação da complexidade tecnológica da capacidade produtiva nacional pela via das parcerias entre institutos de pesquisa de ciência e tecnologia e as empresas, promovidas pelo Ministério da Saúde, encontra também entraves. 
Diante dos editais cooperativos de fomento ao desenvolvimento de protótipos de materiais estratégicos para a saúde, o incentivo que busca aproximar os dois agentes se defronta com a própria cultura apartada entre a iniciativa privada e a área acadêmica. Trata-se de um processo de mudança em curso.

Noutra vertente, o caminho político de fortalecer a produção nacional através do estímulo à regulação sanitária se revelou também como desestímulo a muitos agentes produtores, já que nem todos alcançam cumprir as prerrogativas e contornar seus embutidos embaraços.

Já mencionamos que a política vê vantagem no caminho de aumentar o patamar tecnológico através da acreditação de laboratórios de engenharia biomédica e certificação dos produtos. Aliás, a regulação sobre os equipamentos médicos vem sendo aprimorada desde a constituição do sistema único de saúde.

Um dado interessante é que por longo tempo a regulação sanitária esteve comprometida com os fármacos e medicamentos, e somente agora, com as novas políticas que promovem a inserção da produção nacional na divisão internacional do trabalho, os equipamentos médico-hospitalares entram com vigor nas atribuições da ANVISA.

Antes os selos faziam parte de um diferencial do produto no mercado, agora o mercado se torna restrito somente para aqueles produtos e empresas que estão em conformidade. 0 território se torna uma norma rígida, nesse sentido, de modo que o que circula fora dessa racionalidade se torna um "pirata".

A regulação e fiscalização dos produtos médicos são certamente indispensáveis, e quanto a isso não ouvimos nenhum agente emitir comentários contrários. Todavia, as normas e as verificações da ANVISA chegaram antes do que as condições de infraestrutura do país para certificar nas exigências.

Alguma regra sempre foi prevista, mas sua cobrança é hoje acirrada em função de um processo de aceleração material e organizacional do sistema produtivo de equipamentos médicos.

Além da norma sobre o produto, há a regulação também da produção, chamada Lei de Boas Práticas Fabricação. Essa regra exige transformações no espaço físico das fábricas, de modo que 
é preciso um investimento alto por parte de pequenos empresários.

Vale ressaltar que o arcabouço regulatório está baseado num padrão de qualidade que, ainda que seja ANVISA, sua referência normativa deve servir ao acesso aos mercados internacionais. Ainda mais, os selos "FDA" e "CE" envolvem toda uma dinâmica de consultorias própria dos Estados Unidos e Europa para que sejam efetivados.

Em Ribeirão Preto, a promoção de conhecimento que o APL oferece, através de cursos do SEBRAE, entre outros, permite que os fabricantes da cidade incrementem a capacidade de organização empresarial nesse novo contexto.

Vimos que as empresas que têm conseguindo se estabelecer nos níveis exigidos são aquelas já consolidadas há algum tempo, como 10 ou mais anos, mas também, outras mais recentes que encontram na solicitação ao crédito, comumente em bancos públicos, um meio de se elevar ao padrão da qualidade da norma e garantir a permanência no mercado.

Aqui vale mencionar outros agentes nessa busca de sobrevivência. A ANVISA vem também passando por um momento de mudança organizacional e a observamos pela unanimidade das queixas em relação à demora aparentemente crônica da liberação dos pedidos encaminhados.

A produção nacional atualmente passa por um intenso processo de substituição de uma divisão territorial por outra mais moderna. O que parece representar a criação de novas condições necessárias à introdução de novas técnicas, como nos inspira Santos (1996:32) quando nos lembra Akrich (1987) ao dizer que o objeto define ao mesmo tempo os atores e um espaço.

Os custos e atrasos das certificações parecem se agravar com a velocidade das exigências que os produtores têm tido que lidar. Enquanto a acelerada modernização dos equipamentos médicos é já preocupação prevista pelos produtores nacionais, a aceleração das normas amplia o rol e o ritmo das preocupações à sobrevivência de suas atividades.

Nesse sentido, por mais que haja esse efeito positivo esperado da regulação para aumentar o nível da competição da indústria nacional, o processo de totalização mostra, por um 
momento, as dificuldades, sobretudo, dos fabricantes para fazer sobreviverem suas atividades.

Enquanto o circuito superior marginal de equipamentos médicos se faz possível constatar nesse processo, 0 enquadramento normativo pelo qual passam as atividades nas diferentes cidades revela diferentes situações geográficas. Nesse movimento atual, é o meio construído quem torna possível a expressão diversificada do circuito superior marginal.

Nesse processo de competitividade darwiniana, o fortalecimento da produção nacional se mostra por um mercado interno cuja disputa é plena de obstáculos. Enquanto tais empresas pelejam para adquirir seus certificados, os agentes hegemônicos, como a GE, Philips, aumentam sua participação, renovando até onde vão seus interesses o parque de equipamentos médico-hospitalares do país.

Ainda nessa direção, o nascimento de empresas hoje se torna algo mais dificultoso que em outra época. Por tantos investimentos necessários para responder aos enquadramentos normativos, é possível dizer que alguma espontaneidade tenha sido desfeita.

Pois, ainda que exista o savoir-faire, não se produz sem que, antes, ingresse o poder instituído. Mas, o espaço geográfico é mesmo esse movimento permanente, ensina Santos (1996):

"O processo pelo qual o todo se torna um outro todo é um processo de demanche, de fragmentação e de recomposição, um processo de análise e síntese ao mesmo tempo. Trata-se um processo pelo qual o único se torna múltiplo e vice-versa." (Santos, 1996:97)

Se há casos em que as dificuldades estruturais terminam por eliminar uma empresa, as demandas por atividades terciárias ligadas aos equipamentos de saúde ainda permitem o surgimento de novas. Como produtoras de serviços de assistência autorizada, ou softwares, novas empresas nascem, sendo esse um meio para entrar no mercado para, eventualmente, conquistarem outros mercados. 


\subsection{A força criativa na interdependência do trabalho nas cidades de Campinas, Ribeirão Preto e São José do Rio Preto}

Vimos que a seletividade da divisão internacional do trabalho num país é manifesta por funções repartidas espacialmente. E que a tendência crescente à especialização dos lugares revela um processo de diferenciação que se completa por formas de cooperação também variadas.

A interdependência funcional e hierárquica entre as atividades, entre lugares e regiões intensifica os intercâmbios e expressa um novo patamar do processo de internacionalização da economia capitalista.

Esse movimento desigual e combinado, manipulado pela capacidade dos agentes hegemônicos para imprimir mudança nos sistemas técnicos e mobilizar o excedente em seu favor, se faz, portanto, por um processo em que participam diferentes divisões territoriais do trabalho.

Efeito do curso das modernizações e condição da socialização capitalista $^{56}$ (Topalov, 1974), as diferentes divisões territoriais do trabalho permitem um sistema de vasos comunicantes entre agentes com diferentes níveis de capital, tecnologia e organização.

Essa reflexão nos faz atentar para o fato de que os circuitos da economia urbana não são apenas os resultados, sempre mais

\footnotetext{
${ }^{56}$ A noção de socialização capitalista foi cunhada em 1974 por Christian Topalov, para quem "a cidade constitui uma forma de socialização capitalista das forças produtivas. Ela mesma é o resultado da divisão social do trabalho e é uma forma desenvolvida de cooperação entre as unidades de produção. Em outras palavras, para o capital, o valor de uso da cidade reside no fato de que é uma força produtiva, porque concentra as condições gerais da produção capitalista. Essas condições gerais, por sua vez são condições da produção e da circulação do capital e da produção da força de trabalho" apud Santos, M. 1994:123

M. Santos (1994:122) dirá ainda mais claramente: "Entenda-se por socialização capitalista a criação de capitais comuns, de meios coletivos à disposição do processo produtivo. É socialização pelo fato de que não são os capitais individuais que a devem empreender diretamente; é capitalista porque os beneficiários são poucos, segundo uma hierarquia que vêm do seu poder enquanto capitalista, isto é, de sua capacidade de utilizar produtiva e especulativamente as infra-estruturas financiadas por meio de impostos, com o esforço coletivo, isto é, mediante a contribuição social. A socialização capitalista é, sobretudo, um processo de transferência de recursos da população como um todo para algumas pessoas e firmas."
} 
complexos, das modernizações que os presidem, mas, igualmente, são condições mutantes e diferenciadas de agentes variados e ações múltiplas.

Nesse sentido, o princípio de diferenciação do espaço é traduzido não apenas pelas ações dos agentes capazes da corrida pela inovação, mas também pela resposta que a própria segmentação da economia oferece ao processo de totalização, enquanto cooperação entre as diferentes formas de trabalho.

Entretanto, quando nossa atenção está para a economia urbana neste processo dialético entre segmentar-se e buscar unificar o processo globalizado do trabalho, a cidade aparece por suas formas e nexos, definidos pela coexistência desses atores de força desigual.

A tecnociência, a informação e a finança que, de algum modo, passam a constituir as ações sobre todos os lugares do planeta, tornam mais densa a divisão interna do trabalho em algumas cidades, assim como aumentam a complexidade com a qual se relacionam as novas formas de fazer da cidade.

Como um todo em permanente movimento, a cidade é reconhecida pelo conjunto da base material e da vida que a anima. Vista como meio construído e como grande mercado, assevera Silveira (2004:2), a cidade é um abrigo para a existência de todas as atividades, independente de suas forças.

Ao perguntarmos sobre o comportamento dos diferentes agentes nas cidades, num mercado de acelerada renovação técnica e normativa, como o da saúde, o que se revelou foi a formação e existência de uma porção marginal do circuito superior da economia urbana ligada aos equipamentos médicos.

0 sistema produtivo de equipamentos médicos, sejam hegemônicos ou não seus atores, responde aos imperativos da circulação no período atual. As atividades, especializadas e concentradoras, as demandas, diferenciadas e difusas, imprimem movimento e aceleração ao uso do território. Contudo, as atividades de manutenção dos equipamentos médicos nos permitiram distinguir os atributos da força de algumas empresas para controlar mercados e segmentar o território em seu favor.

Em Ribeirão Preto, a intencionalidade do novo momento produtivo transforma o território usado, de modo que o circuito 
superior marginal se fez observar, sobretudo, pela busca incansável dos agentes produtores para se adequarem às novas funções da cidade.

o circuito superior marginal emergente na cidade pôde ser verificado por dois modos, que se revelaram mais salientes. Um, confundido com o próprio poder das decisões organizacionais públicas, o outro, com o poder de ação, podemos dizer, mais imediato de grandes empresas.

No primeiro, o movimento impresso pelas normas do mercado global e da formação socioespacial para transformar a escala do acontecer da região refaz os arranjos na cidade. 0 que aparece como uma verticalidade mediata, pois as novas necessidades de intercâmbio e regulação são diretamente promovidas pelo Estado.

No segundo, a parcela técnica da produção ali representada desperta o interesse de grandes agentes. A empresa Microem ${ }^{57}$, importante fabricante nacional de alguns produtos eletroeletrônicos, possui um escritório com um funcionário particular que lida com as vendas de ultrasom como representante da Philips.

A gigante Philips parece se interessar pela rede de relações de clientes da Microem, já que esta empresa não fabrica ultrasons. Nesse sentido, a grande firma sobrepõe sua topologia particular, criando novas interdependências para seus produtos, com a ressalva de que isso se dá a partir dos agentes locais.

Como representante de vendas de grandes empresas, a parceria entre fabricantes não-hegemônicos e hegemônicos amplia a escala de ação de ambos. Mas, diferente das verticalidades criadas pelos programas de governo, outra forma de verticalidade organizacional, mais imediata, como dissemos, é um meio habilidoso do comportamento dos atores hegemônicos.

\footnotetext{
57 A Microem foi fundada em 1984 e é importante fabricante de equipamentos médicos no país; possui 52 funcionários e vem aumentando esse número em função da exigência de novos tipos profissionais, como a área de qualidade; seus fornecedores de insumos, muitos estão em Ribeirão Preto; seus clientes, é dito, são frutos da divulgação de muitos anos da empresa em feiras hospitalares. A empresa produz para a área médica e também veterinária. Alguns dos seus produtos são: detectores fetais de mesa e portáteis, doppler vasculares, amnioscópio, cadeira oto/oftalmo, cardiotocógrafo, colposcópio, criocaltério, mesa ginecológica, clínicas e urológicas, negatoscópio, foco auxiliar cirúrgico e clínico, mesas clínicas, videocoloscópio. Ainda, vende também ultra-som Philips. Cada unidade é testada individualmente, sendo que esses testes devem garantir a segurança do produto médico. A empresa possui normas rigorosas de produção, sendo este um meio de atender aos padrões internacionais de qualidade para, então, ocupar mercados fora do país.
} 
A criação dessas funcionalidades com o circuito superior não é apenas a condição de existência da sua porção marginal emergente, mas também a evidência de que a interdependência contemporânea é, ela mesma, criadora do circuito superior marginal.

Poderíamos ainda mencionar uma terceira observação, que são aquelas empresas mais antigas, que se encontram consolidadas há mais tempo na cidade, como a Deltronix em Ribeirão Preto, ou a Drake em São José do Rio Preto.

Essas empresas normalmente possuem um, ou poucos produtos, em que são únicos fabricantes no país, além de produzirem outros. Contudo, ainda assim, se veem vulneráveis diante da necessidade de responder permanentemente à acelerada renovação técnica e normativa.

São José do Rio Preto, como dissemos, participa também do Sistema Paulista de Parques Tecnológicos, sendo que este é um projeto em andamento. Enquanto esse evento encontra o arranjo mais adequado à sua funcionalização na cidade, vimos algumas atividades ali abrigadas.

A Drake é uma empresa cuja tecnologia é relativamente mais complexa. Casos menos comuns na produção nacional, seus funcionários são em maioria profissionais com curso superior em diferentes áreas.

Os fornecedores estão em países como Japão, Alemanha, EUA, mas uma pequena porcentagem dos analisadores de gases sanguíneos é importada, entretanto trata-se de uma parte indispensável na fabricação desse aparelho. Costumam usar o máximo possível de insumo nacional, mesmo que o custo seja maior, por conta da facilidade do contato e eliminação de burocracias.

Mais da metade dos seus insumos vêm de São Paulo e o restante, da própria região de Rio Preto, com fornecedores menores. Principalmente porque são únicos fabricantes no país de determinados produtos. Quando é assim, a empresa produz também a família de equipamentos que o acompanha.

Nesse caso, tal exclusividade, explicada pelo dono da Drake, advém do fato de ter trabalhado na área da saúde e, com efeito, ter extraído dali a idéia de fabricação do equipamento. Por conhecer determinado aparelho que, na ocasião, era importado, a 
Drake reconheceu a oportunidade de imitar o objeto, agregando os materiais produzidos nacionalmente e importando apenas algumas peças.

Todavia, embora estejamos falando de uma empresa de maior complexidade tecnológica, as outras empresas como Microem, Martec, Lumar de Ribeirão Preto, também a Komluz, de alta tecnologia, a Bioluz em Campinas, todas imitaram produtos importados a partir de conhecimento na área da saúde e na área técnica, agregando insumos nacionais e algumas peças específicas importadas.

É nesse sentido que as fabricações também se atualizam em níveis tecnológicos, agregando partes mais sofisticadas, informatizando-se, mas sobre os mesmas bases. Para tanto, há os congressos, as feiras, onde acompanham as novidades (mais potente, mais rápido, mais fácil, não quebra, consome pouco reagente, etc) e observam como estão agindo os concorrentes.

A Drake nasceu em São Paulo, mas migrou para Rio Preto, mantendo na metrópole um escritório de vendas, assim como alguns fornecedores de insumos. Trata-se de uma evidência do processo de desmetropolização e o trabalho intelectual presidindo a organização da produção.

Tal mudança levou a empresa a diminuir o número de funcionários e, atualmente, são 25. Nesse movimento, a mecânica menos especializada que antes fazia na fábrica, hoje é terceirizada. Com maior capital que muitos outros fabricantes do ramo, seu mercado consumidor está em todo Brasil e também América Latina. Além disso, a empresa possui um funcionário que transita noutras regiões do país para dar assistência técnica e instalar seus produtos vendidos.

Daí a tática de muitas empresas maiores espalharem representantes de seus produtos no território nacional, pois com a produção na Região Concentrada, sobretudo em São Paulo, as empresas com maior nível de capital e capacidade tecnológica são capazes ter maior organização da sua topologia particular.

Como muitas empresas nacionais não têm o nível de capital da Drake, por exemplo, alcançam, de outra forma, as outras regiões do país. Isso é, não têm autonomia para controlar por si mesmas seu nível de organização, pelo contrário, o comércio de seus produtos depende de diferentes distribuidores. 
Por meio dos representantes, as empresas mais modernas, como a K Takaoka, em São Bernardo do Campo, criam uma demanda de treinamentos técnicos específicos, passando a profissionalizar os funcionários da sua representante, a LAC, em Campinas.

Por se tratar de equipamentos médicos, deve ser urgente o atendimento a esses objetos quando precisam de consertos, daí os serviços de instalação, as instrução de uso, a assistência técnica especializada estar crescentemente atrelados ao comércio como um serviço pós-venda. Aqui, entende-se essa importância, no entanto, quando falamos das empresas ligadas ao circuito superior puro, essa característica pós-venda aparece como pretexto para que mecanismos de oligopolização sejam estabelecidos.

Nesse caso, por se tratar de equipamentos muito sofisticados, os serviços pós-venda são realizados por profissionais próprios da Siemens, Philips, GE, sendo que são pessoas que circulam no território, aparentemente sem local fixo. 0 ponto é que esses serviços fazem parte do sistema de garantia de venda dos objetos. 0 que mostra outro modo do sistema técnico hegemônico obstruir o surgimento de demandas na economia da cidade.

Como dissemos anteriormente, não são os fabricantes que entram nas licitações, pois é preciso uma área dentro da empresa dirigida apenas para o aproveitamento desse mercado. Nesse caso, são os representantes locais, que estão mais próximos das demandas dos lugares.

Para conhecermos que alguns agentes nacionais, mesmo usando o território de forma hegemônica, encontram-se numa situação de vulnerabilidade, mencionamos um caso particular da Drake, fabricante de analisadores de gases sanguíneos, comuns em pronto socorro e locais de cirurgia.

Seus concorrentes no mercado mundial desses aparelhos de gasometria e íons seletivos são a Bayer e a Roche. Conhecendo o poder dessas grandes empresas, que trabalham com uma lista bem mais ampla de produtos, a Drake sabe que se aquelas a julgarem esbarrar em algum de seus interesses de mercado, é decisiva a força que têm para devorá-la.

Daí dizermos que um dos modos de existência do circuito superior marginal é pela ocupação de interstícios praticados na economia urbana. Ainda que a empresa seja de tecnologia mais 
complexa e seu produto encontre sentido num mercado interno, o circuito superior marginal se caracteriza pela vulnerabilidade de seus agentes.

Nesse sentido, as vigilâncias federal, estadual, municipal, os alvarás necessários, a demora da liberação das certificações da ANVISA, os custos altos - reclamações de todos os agentes que tivemos oportunidade de entrevistar - se tornam justificações dos agentes a respeito das suas dificuldades.

Dificuldades estas que apontam não conseguirem conter a invasão dos produtos chineses, muito baratos. Recentemente o Brasil $^{58}$ referendou a aplicação do direito de antidumping para a importação brasileira de seringas descartáveis por um período de cinco anos.

Desse modo, vemos como os circuitos da economia urbana não são apenas expressão das diferentes divisões territoriais do trabalho, mas uma condição relativa em permanente movimento, relativa ao modo como a lógica do Estado e do mercado realiza o processo de modernização.

Enquanto a produção nacional se fragiliza pela sobreposição de normas, bem como pela lentidão dos processos de certificação, as multinacionais se instalam no país, importando intra-empresa para apenas montar no país e exportar aos países da América Latina.

No âmbito da manutenção, o que observamos foram novos mecanismos de criação de atividades subordinadas aos interesses hegemônicos. Daí porque as atividades de manutenção se revelaram importantes para perseguirmos os modos pelos quais há um circuito superior marginal vinculado aos equipamentos médicos.

Mesmo que os serviços de manutenção venham imbuídos de um discurso de eficiência, que se refere à proximidade como dever

\footnotetext{
${ }^{58} \mathrm{O}$ Comitê Executivo de Gestão (Gecex) da Câmara de Comércio Exterior (Camex), em reunião realizada no Ministério do Desenvolvimento, Indústria e Comércio Exterior (MDIC) decidiu em 18 de setembro de 2009 o antidumping sobre as seringas chinesas. O direito antidumping é uma medida clássica de defesa comercial utilizada para evitar que produtores nacionais sejam prejudicados por importações desleais, sendo amparada pela Organização Mundial do Comércio (OMC) quando há confirmação da prática de dumping, exportação de bens para outros mercados com preços inferiores ao praticado no mercado de origem. - texto extraído do Ministério do Desenvolvimento da Indústria e do Comércio Exterior. O Brasil possui grades e antigas empresas fabricantes de seringas capazes de suprir o mercado interno.
} 
de um serviço realizado com agilidade para à vida do paciente, essa justificativa não sustenta a complexidade dos mecanismos de criação de hierarquias e escassez na economia urbana.

Ainda em São José do Rio Preto, pudemos observar esse processo de perto. As atividades dos equipamentos médicos estão vinculadas às diferentes áreas de conhecimento. A manutenção está, em grande medida, vinculada às engenharias e a cidade, aparece como uma oportunidade para que atividades de reparo ocupem interstícios.

Como forma de ingressar no mercado de equipamentos médicos, sem precisar atravessar o mesmo arsenal normativo que se desenha para as atividades de fabricação, as empresas de manutenção nascem diante das demandas diferenciadas por serviços na região.

Uma vez nos lugares, muitas atividades de reparo se transformam também numa extensão do fabricante longínquo, isto é, revela-se como capilaridade das empresas maiores. Entretanto, essa relação não é apenas necessidade das grandes empresas de assegurar circuitos hegemônicos na economia urbana, mas oportunidades das empresas menores, que encontram meio de sobrevivência.

Por mais perverso que seja esse modo de integrar atividades genuínas numa funcionalidade hegemônica, é preciso reconhecer o sentido da ação no contexto próprio dos agentes, na contiguidade qual pertencem. Nesse sentido, é esse o modo como a cidade abriga as atividades de manutenção: uma racionalidade do lugar e uma ordem hierárquica se fazem mutuamente, aumentando o nível de organização de cada uma das empresas.

As manutenções são, então, atividades surgidas de demandas insatisfeitas que se exprimem por uma diversidade de formas de trabalho. Mas, pela própria particularidade de serem esses objetos médicos e os serviços de saúde fixos geográficos, mecanismos de verticalização da economia urbana vêm se utilizar das relações contíguas por meio da assistência autorizada.

o que vemos é a existência marginal de um circuito superior dada por um acontecer hierárquico. Ambos os circuitos trabalham juntos, já ensinara Santos (1994):

"utilizando a cidade como um mercado unificado de mão-de-obra, de economias externas, de capital e o lugar do consumo também 
unificado. Graças às diferenças de nível tecnológico e organizacional, há, de fato, mais que complementaridade, uma verdadeira cumplicidade ao nível de mercado.” (Santos, 1994:96)

Em Campinas, pudemos observar singularidades nesse processo de totalização. Sabemos, com Santos (1994:100), que quanto maior a cidade tanto mais ela se torna sinônimo de mercado acessível. Nessa perspectiva, a densidade das divisões territoriais do trabalho, resultado da sucessão histórica de sistemas técnicos superpostos na região, permite a existência de uma produção diversificada.

Essa produção, tanto de bens como de serviços, serve a um mercado de consumo de uma fração mais exigente tanto quanto ordinário. Sendo assim, uma economia da saúde se vale da região como meio construído e como grande mercado, onde pequenas e médias empresas usufruem de uma produtividade espacial para a saúde, cuja vantagem acaba por ser tanto mais importante quanto menor a firma.

As existências que na cidade estão relacionadas às atividades de manutenção de equipamentos médicos se mostraram por uma diferenciação de formas de trabalho que queremos apontar. Nascidos pela possibilidade da prévia formação em cursos técnicos especializados historicamente consolidados na cidade, tais agentes desempenham suas atividades na economia urbana.

Sabemos que a unicidade da técnica vem transformando nossas liberdades de escolha, mas essa realidade sobre a vertente dos equipamentos médicos exprime algumas nuanças que nos parecem importante considerar, diante da pretensão de uma análise abrangente.

Já dissemos que a globalização é produzida a partir das três unicidades que se dão em conjunto, a unicidade da técnica, da informação e do dinheiro. Nesse sentido, os benefícios pós-venda assegurados pelas compras desses objetos responderiam a uma demanda autêntica do lugar se não fosse de interesse dos maiores agentes sincronizar-se com o acontecer dos lugares.

Deixemos mais nítido. A assistência técnica que os equipamentos precisam e a proximidade da manutenção terminam por constituir elementos que convidam essas atividades nãohegemônicas a participar de mecanismos aprimorados da divisão do trabalho hegemônica para criar relações de subordinação. 
Nesse sentido, ainda que a manutenção de objetos constituídos de nova base científica seja uma necessidade, a idéia de gerenciamento de qualidade, dada por aspectos vinculados às peças e marcas, ou às propriedades informacionais e informáticas, parece sustentar um discurso científico da eficiência para atualizar a subordinação de antigas atividades de reparo.

Os objetos médicos modernos fazem cada vez mais importantes as atividades de manutenção preventiva e de engenharia clínica, entretanto, com atenção à economia urbana, é também saliente que atividades autônomas de manutenção se tornam comprimidas por um mercado tomado por representantes de empresas maiores, desautorizado-as.

Daí nossa atenção a um movimento mais amplo em relação ao caráter político do processo de cientifização do trabalho e obsolescência das profissões. Ainda que muitas atividades demonstrem uma habilidade técnica para produzir bens ou serviços, a economia política da cidade mostra as possibilidades assim como as perversidades do período atual.

De qualquer modo, há níveis dessa relação. Vimos empresas que são completamente definidas pelos papéis que a empresa maior lhes atribui. São representantes exclusivos, como a LAC, proibidos de dar manutenção às marcas concorrentes, responsáveis por uma região definida dentro do estado de São Paulo, por sua vez, controlada pela empresa-mãe K Takaoka, que possui representantes em todo o país.

Mas há ainda representantes exclusivos menos integrados à lógica da empresa mãe, como a Biocam. Isso se deve a organização da divisão do trabalho interna à empresa maior. Ou seja, a Biocam não representa produtos concorrentes, mas também sua lógica não é uma reprodução da empresa-mãe.

Nesse caso não estamos falando de uma firma estrangeira multinacional, mas de uma grande e antiga fábrica brasileira, $\mathrm{K}$ Takaoka. Residente na região metropolitana de São Paulo, possue uma estrutura interna que aglutina, como "família", seus representantes em todo país.

Por terem equipamentos médicos no Brasil todo, a empresa-mãe se utiliza das atividades de seus representantes para prestar a assistência, mas também leva o discurso da marca, sendo essa 
"integração familiar" uma estratégia de renovação técnica e política com seus clientes, a partir da modernização dos seus próprios aparelhos.

Os representantes não são grandes empresas, mas possuem uma organização que permite ação na contiguidade, e que se torna funcional a ambas as empresas, mãe e filha. Conta com técnicos de manutenção de aparelhos, que se deslocam até o equipamentoproblema, consertam ali ou trazem à firma para o reparo.

A LAC possui um ambiente de manutenção, com técnicos que consertam ali os problemas mais complexos. Ainda há os técnicos que visitam os clientes fazendo reparação preventiva, assim como corretiva, pois muitos equipamentos estão parados por falta de acessórios e não porque estão estragados.

$\mathrm{Na}$ ocasião das visitas de manutenção preventiva, há uma transmissão dos modos de fazer do aparelho para o operador, como se os objetos e a marca que o faz especial em algum aspecto ensinassem os homens a trabalhar em suas profissões dentro de um hospital, onde não são apenas os médicos, mas enfermeiros, técnicos entre outros.

Há vendedores externos, aqueles que visitam os hospitais e clínicas, também as prefeituras, que oferecem os produtos àqueles que ainda não são clientes. Há também vendedores internos, aqueles responsáveis pela venda, mas que por serem os representantes na região, são os próprios clientes que os procuram.

Há atualmente uma exigência da ANVISA em promover a rastreabilidade de cada peça e dos aparelhos, com número de série e para quem foi vendido. Isso nos aparece um modo de regulamentar um mercado de peças de segunda mão, impedindo ações ilícitas, como roubos etc, mas também, as manifestações espontâneas da socialidade.

Ainda, nesse âmbito dos representantes, muitas atividades de manutenção encontradas nas cidades revelam a capilaridade das empresas hegemônicas para estarem próximas de seus mercados. Segmentam assim o uso do território à sua topologia de conveniência, extraem de seus representantes informações precisas de um mercado que quem conhece é o próprio representante. 
Os treinamentos técnicos particularizados são exigidos por aqueles que são representantes de manutenção e oferecidos pela empresa-mãe, numa frequência que se parece com a das inovações ou incrementos dos objetos.

Nesse sentido, os treinamentos capacitam à venda, à instalação e manutenção dos produtos dentro das especificidades da marca. Da mesma forma, são fontes de informações particulares de cada mercado regional para a grande empresa para que monitore seu domínio.

Esses treinamentos obrigatórios aos representantes são, de algum modo, responsáveis por atualizar os diferentes agentes quanto às novidades médicas. Daí que enquanto a empresa-mãe assume os gastos com publicidade numa outra escala, a empresa representante tem cativa demanda. Tal mecanismo demonstra um modo de fazer da difusão das modernizações.

Sistemas técnicos, que são, por natureza, instrumentos para procedimentos médicos modernos, são, também, e antes, organização da divisão territorial do trabalho. Nesse sentido, a força sistêmica das técnicas se mostra para organizar as solidariedades na economia urbana e transformar o espaço geográfico no processo de reintroduzir nova técnica.

A temporalidade dos diferentes agentes converge mediante a interdependência fina que se estabelece pelo comando da representação e da assistência autorizada. Justificada pela unicidade da técnica e trazedora de eficiência essas atividades de manutenção são acompanhada de seu discurso.

Ainda nessa direção, quando damos atenção às assistências que são um nível mais brando de representação, vemos maior flexibilidade do agente para responder por si próprio às demandas de mercado. Mas, de qualquer modo, quanto à assistência técnica de representantes, as peças são comumente próprias do fabricante.

Em alguns casos, todas as peças de reparação são peças próprias da marca e esse é um compromisso do representante. Mas há outros em que há uma flexibilidade de trabalho com outros agentes e apenas algumas peças mais estratégicas são da própria marca. 
As peças de reparo com especificidades dadas pela marca são segredos técnico-científicos destinados a proteger a originalidade da fabricação, mas, também, como vimos, para controlar sua política organizacional sobre as subalternas. A indisponibilidade para permitir estoques expressa um modo da criação de escassez, num processo que é um verdadeiro subjugo da capacidade produtiva na cidade.

Se a empresa de assistência vende essa peça de marca para uma empresa de manutenção que não é autorizada, a manutenção desautorizada torna o serviço sem garantia pelo fabricante. Ainda mais, na instalação, oferecem um arsenal de informações técnicas científicas que dão suporte e instrução ao operador do aparelho, para que possa manter o equipamento em bom estado de funcionamento.

Pudemos verificar também o recurso que encontram algumas atividades de manutenção para comprar, consertar e revender os aparelhos. Nesse momento de revenda, os clientes são então convidados a fazer manutenção preventiva, tornando o consumidor integrado num sistema de demandas com determinado fabricanterepresentante.

0 encontro dessa diversidade de usos do território parece nos mostrar uma perspectiva do sistema de vasos comunicantes que são os circuitos da economia urbana. Nesse tempo em que o papel da organização ganha uma força na diferenciação entre empresas mais e menos poderosas (Silveira, 2007), somos convidados à pergunta sobre como se estabelecem as relações de cooperação e conflito, dado que coexistem.

Nesse sentido, procuramos compreender a cidade em sua dinâmica solidária e contraditória. Isso implica adentrar os circuitos da economia urbana pelo que apresentam em filigrana e buscar compreender por meio dos usos do território, usos que são sempre presente, o significado dos novos nexos de interdependência.

\subsection{O cotidiano compartilhado nas cidades de Campinas, Ribeirão Preto e São José do Rio Preto}

Temporalidades práticas de uma diversidade de formas de trabalho, os circuitos da economia urbana constituem 
interstícios ocupados por atividades marcadas pelo signo da falta, mas cuja condição implica um processo criativo contraditório que tanto limita quanto convida a ação.

0 modo como cada grupo de agentes usa as variáveis-chave do presente, como o são a tecnociência e a informação, indica as diferenças de situações de existência, pois os atores não têm igual força na realização das possibilidades (Silveira, 2008:59)

Esforço de um exercício analítico para interpretar o período como movimento unitário de impactos seletivos e para, além de tautologias, captar as diferentes manifestações dos eventos, pudemos reconhecer esse modo desigual e combinado pelo qual o tempo universal se torna empírico.

Santos (1996:132) é quem nos ensina contemplar esse processo espacial como um acontecer solidário, definido como a realização compulsória de tarefas comuns, mesmo que o projeto não seja comum.

Nesse sentido, o acontecer solidário faz aparecer a diversidade das divisões territoriais do trabalho na produção coletiva do nosso tempo, ainda que "essas interdependências tendam a ser hierárquicas e seu papel de ordenamento transporta um comando" (Santos, 1996:226).

Como os atores não têm igual força para realizar as possibilidades do período, o acontecer solidário se revela nas combinações dessas três formas: o acontecer homólogo, o acontecer complementar e o acontecer hierárquico.

0 acontecer homólogo é a base da construção das áreas modernizadas, gerador de novos desenhos na contiguidade. Como ensina Silveira (2008:60), são existências que deixam ver a primazia das formas e das técnicas. O Arranjo Produtivo Local em Ribeirão Preto é revelador de um acontecer homólogo.

O acontecer complementar é criador de novas relações entre as cidades. Orientadas pelas diferentes demandas de uma circulação moderna, novas complementaridades regionais despontam. O Arranjo Produtivo Local em Ribeirão é revelador também de um acontecer complementar, na medida em que vem criar novas relações da cidade com sua região.

Mas também atividades menos modernas criam complementaridades entre cidades. Em função das modernizações em saúde nessas 
cidades, há atividades que ocupam novos mercados através da representação de novos produtos, mas mantendo a atividade prévia de manutenção de equipamentos menos modernos nas cidades vizinhas, isto é, nos serviços de saúde menos modernos.

Como explica Santos (1996), o acontecer hierárquico é feito de ordens e informações que provêm de um lugar, mas se realizam em outro. Ainda, Silveira (2008:60) mostra que "a primazia das normas e a relevância da política" são centrais na definição do acontecer hierárquico. Esses eventos terminam por mobilizar os outros agentes, alimentando a racionalidade dos demais aconteceres.

Nesse sentido, os eventos produtores dos conteúdos da existência não são todos da mesma natureza, apesar do processo de racionalização crescente do território nutrir que os eventos sejam apenas os vetores da intensidade e da velocidade contemporâneas.

Desse modo, reconhecer as diferentes temporalidades e sentidos da ação, não apenas os dos agentes hegemônicos, expulsa o risco do discurso único da globalização impor-se como projeto comum e inelutável a todos ou ainda ofuscar as possibilidades da percepção e interpretação do novo.

Nesse sentido, pois, é que a cidade não pode ser vista somente pela economia moderna, pelas divisões territoriais do trabalho hegemônico, pelo circuito superior. 0 meio construído, constituído pelos atuais sistemas técnicos e aqueles herdados, manifesta formas de trabalho que nascem nos interstícios, respondendo às demandas sociais.

Como assevera Montenegro (2006), firmas que desempenham um tempo mais lento usam o território como um abrigo, revelando o papel do meio construído como condição para seu poder de mercado. Daí observarmos a importância do que nos ensina Silveira (2004) ao dizer que a cidade é vista como o conjunto da base material e a vida que a anima, pois nela todas as atividades encontram seu lugar. Ainda a autora (Silveira, 2998):

"Um olhar para suas formas de trabalho e relações com o meio construído permite refletir sobre os conteúdos existenciais do espaço, ou seja, a vida e as técnicas, que indicam como o território é usado. As formas de trabalho que compõem o circuito inferior e o circuito superior marginal no período atual podem ser vistas como 
divisões de trabalho espontâneas que nascem nos interstícios do circuito superior." (Silveira, 2008:64)

Para quem estar no mundo é estar em situação, Heidegger (1958) nos inspira quando Santos (1994:96) assevera que o circuito superior marginal aparece, ao mesmo tempo, como um obstáculo à oligopolização completa da economia e como uma de suas condições.

As atividades possuem "enraizamento" num contexto para o trabalho e para o consumo. Daí a cidade, concebida como meio construído e como mercado, permitir a existência de uma diversidade de agentes, cujas formas de trabalho deformam a intencionalidade que lhes vêm, atribuindo a partir de suas relações, novos sentidos da ação.

Nessa direção, observamos que é na ação presente e na presentificação do prático-inerte que há o reconhecimento das tendências definidoras do período, alerta Silveira (2008:64). Nesse esforço analítico, buscamos apontar algumas observações na constituição das situações geográficas nas três cidades.

o comportamento da porção marginal do circuito superior na cidade que o aproxima de um circuito inferior pôde ser observado por atividades que, diante da modernização dos serviços de saúde, são impelidos a confrontar o risco de obsolescência da sua produção.

Nesse caso, mencionamos aquelas atividades que, antes, faziam manutenção de equipamentos de raio $x$ analógico, assim como vendiam e prestavam assistência técnica a processadoras de filmes, filmes para exames e outros produtos assessórios na região.

Com um processo crescente de digitalização dos exames, a Akathec, em Ribeirão Preto, vem sofrendo os efeitos desse processo de mudança do seu mercado. Tintas e papeis especiais são novas demandas.

A Akhatec vem procurando estabelecer novas parcerias com novos produtores encontrados, por exemplo, nas feiras hospitalares, acrescentando essa forma de trabalho mais moderna, mas sem deixar de atender aqueles que ainda demandam serviços menos modernos, como nas regiões vizinhas. 
Nesse sentido, as feiras de produtos e fabricantes hospitalares são importantes para recorrerem a novos fornecedores, estabelecendo novas cooperações, diante das modernizações. Com produtos mais modernos, comumente esses fornecedores são firmas que possuem escala de produção e de ação mais larga.

A China aparece com peso na dinâmica do mercado interno, por possuir produtos modernos, pequenos e relativamente mais baratos, mas nem sempre de boa qualidade. Ainda no caso da Akathec, como na manutenção, a proximidade do equipamento médico é necessária, um diferencial no trabalho oferecido pela empresa é a rapidez no atendimento, os serviços aos fins de semana e feriados, o orçamento sem compromisso no local.

São esses mecanismos possíveis numa região de grande demanda em saúde que puderam nos mostrar o esforço de sobrevivência de alguns agentes, ao mesmo tempo em que o meio construído revela sua condição de existência.

Dessa maneira podemos observar o caráter misto do circuito superior marginal que, influenciado pelas ações hegemônicas, revela-se tanto por um trabalho segundo parâmetros modernos, o que o torna próximo do circuito superior, como por um trabalho que é, antes, resposta às necessidades de consumo localmente instigadas, o que o torna próximo ao circuito inferior.

Esses agentes trabalham sob o reflexo das variáveis do período que, ao se tornarem dominantes nos serviços de saúde, implicam revisões permanentes das demandas de suas atividades. Entretanto, encontram seu mercado, mais e menos moderno, na região e, ali, suas atividades reconstróem seu sentido.

Em Ribeirão Preto, os novos nexos da cidade mostram que a região passa a exercer um fator de concentração para as solidariedades das atividades de outros fabricantes, na medida em que nela surgem oportunidades, como o serviço tecnológico de certificação oferecidos pelos novos laboratórios (CEDINA), imprescindíveis serviços e fixos raros no território nacional.

Outro aspecto interessante que nos fala do papel do meio construído na totalidade que é a cidade, é o fato de uma importante empresa nacional, a Embracrius, ter falido na década de 1980. O que significou um grande número de pessoal qualificado para empreender seu próprio negócio. 
Daí também uma explicação, embora parcial, da diversidade de empresas e de produtos fabricados na cidade. Nesse sentido, revela grande diferença em relação à Campinas em que as empresas mais recentes mostraram ter nascido por conta das escolas de formação técnica específica na área e cursos superiores de áreas afins.

Já em São José do Rio Preto, as empresas de manutenção que foram observadas apresentaram um comportamento muito próximo de um circuito inferior, embora pratiquem atividades para serviços de saúde modernos na cidade.

No caso da Mac's, a empresa era formada apenas pelo dono e seu filho, que trabalhava também com conserto de computadores. Essa micro empresa nasceu depois de o dono terminar o curso técnico em aparelhos eletromédicos em São Paulo. Quando foi convidado por médicos que estavam se mudando para cidade para abrir sua empresa em Rio Preto, em 1985.

Ainda hoje a Mac's trabalha para as clínicas desses médicos como assistência técnica de equipamentos radiológicos. Mas a empresa também presta serviços em muitos outros lugares da cidade e da região. Perguntado sobre a relação da sua atividade com as cidades vizinhas, disse que "falta mão-de-obra, mas não posto de trabalho".

$\mathrm{Na}$ situação geográfica que definimos em Campinas, pudemos observar alguns distribuidores de materiais hospitalares de diferentes níveis de capital, trabalho e organização. De um lado, no centro de um distrito municipal de condomínios de classe média e alta, Sousas, a atividade conta com um mercado de consumo que tende aumentar, os "homecare".

A Romed tem como estratégia vender para mercados menores como clínicas estéticas, farmácias pequenas, bares e restaurantes, além do diferencial da alocação de equipamentos individuais, como macas, cadeiras de roda, e a entrega a domicílio de curativos especiais.

Nesse serviço, a empresa conta com enfermeiras parceiras que, em visita à casa dos pacientes, indicam seus produtos. Esse mercado de equipamentos pessoais vem crescendo, já dissemos, pela diminuição das internações hospitalares, assim como o envelhecimento da população revelado na pirâmide etária brasileira. 
Por um mercado que se expande em função de novas modalidades de cuidado domiciliar, a Romed é distribuidora para lojas na cidade, mas também possui uma pequena loja, além de fazerem entrega de materiais usando os serviços de motoboys. Por isso mesmo são obrigados a ter gastos com publicidade, como panfletagem, jornais de bairro, etc.

Esses distribuidores têm a característica de trabalhar com uma variedade de produtos, como estetoscópios, seringas, agulhas, gel para exames, lâmina de bisturi, atadura, materiais de paramentação, aparelhos de pressão, entre outros. Mas, quanto menores são, mais dedicados estão às demandas locais e, podemos dizer, privadas.

Nesse caso, abastecem seus estoques com intensa frequência a partir de parcerias com distribuidores maiores na região metropolitana de São Paulo. Resultado também da capacidade física de estocagem dos produtos que, por sua vez, demandam uma regulação específica, por serem materiais médicos.

Ainda, possuem parcerias com empresas internacionais que encontram nessas pequenas firmas uma representação da sua marca. Mas também são abastecidos por fabricantes regionais, assim como grandes lojistas antigos no centro de Campinas.

De outro lado, atividades de distribuição de porte relativamente maior, por sua capacidade de estoque, possuem uma área de mercado numa região contígua de raio largo no entorno da cidade. Possuem seus próprios transportes, que devem ter inspeção sanitária, e têm também vendedores pela região.

Pelo porte, os distribuidores são dinâmicos e variados. Podem comprar de fabricantes nacionais e fabricantes estrangeiros, e também de importadores. Sendo que é comum que o número de intermediários entre um distribuidor e outro seja gradativamente definido pela capacidade de capital desses agentes.

Por isso, o número de intermediários para que produtos de consumo cheguem a farmácias e casas cirúrgicas nas cidades parece responder à capacidade de compra do agente. Daí os fabricantes e os importadores estarem no topo desse circuito produtivo, pois vendem em grandes quantias, “dissolvendo" a produção em diferentes divisões territoriais do trabalho. 
Tais distribuidores, sejam os grandes, como a Hospmed, ou os pequenos, como a Romed, trabalham com diferentes marcas, importadas e nacionais. Nesse sentido, quando o próprio fabricante visita os hospitais e clínicas para ofertar seu produto, ele indica "seu" fornecedor-distribuidor mais próximo.

Essa capacidade de organização revela diferentes níveis de distribuidores que, por sua vez, possuem diferentes graus de capital. Os agentes com maior organização procuram trabalhar com soros fisiológicos, material de intenso consumo médico e hospitalar, que traz maiores rendimentos que luvas, cujo consumo é também intenso.

Mas, para tanto, as empresas são obrigadas a ter um funcionário farmacêutico, daí que isso se torna mais um elemento que irá nos dizer que quanto maior o nível de organização dos distribuidores, maior o nível de capital.

Nesse sentido, vemos os distribuidores desempenhando papéis em cascata na rede urbana, sendo que a depender de sua capacidade, principalmente de capital e, com efeito, organização, maior será sua capacidade de servir às compras públicas.

Por outro ângulo, já destacamos Campinas pela existência de universidades, institutos de pesquisa e indústrias de tecnologia de informação, condição que permite a existência de empresas que, de algum modo, têm relação com essas instituições.

A existência de representantes de outras empresas nacionais é bastante comum, ainda mais por se tratar de uma região de referência em saúde. Os maiores fabricantes nacionais que têm uma lógica territorial de organização da distribuição de seus produtos no país, comumente da região metropolitana de São Paulo, pesquisam firmas que já existem para serem "parceiros".

Como a região de Campinas é uma densa economia de aglomeração para a saúde, as firmas terminam por representar mais de uma empresa, diversificando seu próprio mercado. Também, a existência da incubadora de empresas da UNICAMP surge como oportunidade não apenas para fazer nascer uma nova empresa, mas também para fazer nascer um novo produto de uma empresa já existente como representante, ampliando sua atuação num mercado que já conhece. 
Nesse sentido, verificamos uma empresa que mesmo sem deixar de ser representante, desenvolveu um produto novo na incubadora em parceria com um pesquisador e, atualmente, espera as certificações da ANVISA. Para tanto, a firma teve que readequar todo seu ambiente físico para que pudesse ter $o$ selo de fabricação.

Aqui vemos um círculo vicioso, a empresa não pode fabricar ou comercializar enquanto não tem os selos, e a demora maior do que o tempo determinado pelo próprio órgão regulador começa a comprometer a empresa, pois não pode vender sendo que teve que fazer investimentos para estar adequada e obter a certificação.

Noutra condição, estão aquelas empresas que se valorizaram pela experiência em pesquisa e desenvolvimento da fibra-ótica no país. Já mencionamos a Komluz, é uma empresa pequena, mas com um nível de organização que dificilmente poderemos tratar como circuito superior marginal e sim como circuito superior.

0 que mostra bem que não é pelo porte que conseguimos definir o circuito superior marginal ligado aos equipamentos médicos. A matéria-prima que a Komluz precisa para fabricar seus produtos é importada. Trata-se de um insumo que é um monopólio mundial, onde essa multinacional vai comprando outras empresas por interesse ou confronto.

0 restante dos insumos são produtos nacionais. Como é uma empresa que realiza inovação, não tem muitos clientes que são consumidores finais. Quando desenvolvem seus produtos, procuram seus parceiros nas feiras hospitalares e congressos, e são estes que participam de licitações e vendem no mercado interno.

Já quando há exportação, a empresa fabrica e vende ela mesma. Também por ser uma empresa de inovação, os funcionários, de modo geral, estão sempre tendo que avançar seu nível de escolaridade. Antes eram 40 funcionários e atualmente são apenas 25 .

Por sua experiência pioneira e consolidação em inovação, a Komluz oferece serviços de consultoria em pesquisa e desenvolvimento às maiores empresas nacionais, da região de Ribeirão Preto e São Carlos.

Um caso interessante que é permitido por essa empresa é que o conhecimento de um equipamento médico importado de uso no serviço de saúde em Campinas pode despertar o interesse num 
pesquisador que faz uma parceria com a Komluz para desenvolver o produto nacional.

Isto é, dá-se o que preferimos chamar com G. Tarde (1921) de imitação. A difusão acelerada e generalizada dos objetos em escala global e as demandas insatisfeitas permitem, ainda mais intensamente, a imitação de objetos.

Nesse sentido, assim como a Komluz permite a imitação de um produto importado, por ser uma empresa de inovação, seu próprios produtos sofrem imitação de concorrentes depois que lançados no mercado. Por isso, apesar do porte da empresa, parece haver segredos de produção, assim como se dá no circuito superior.

Já quando vemos sobre a incapacidade de se modernizar ao ritmo da época, as atividades de manutenção de equipamentos médicos mais uma vez nos permitem um universo para observar o alargamento do circuito superior marginal e sua natureza criadora de economia.

Os equipamentos de pressão arterial, por exemplo, não se tornaram obsoletos com a chegada dos digitais. Principalmente para os prestadores que prezam por qualidade de serviço, os equipamentos digitais de pressão não têm uma forma padronizada de calibração que garanta a precisão da medição, adequada para o uso médico-hospitalar.

Aqueles agentes que realizam a manutenção destes aparelhos de pressão continuam a fazê-la, pois há uma demanda por consertos, calibrações, certificações trazidas pelos hospitais e clínicas da região de Campinas. Assim, à medida que alguns serviços de reparação de equipamentos mais modernos vêm exigir conhecimento científico e treinamento técnico, outros serviços se mantêm artesanais, como a atividade de amolar tesoura cirúrgica.

O selo de certificação, obrigatório ao serviço de manutenção, garante que o trabalho prestado esteja autorizado nos termos oficiais, entretanto, aparece como um freio ao desenvolvimento de outras atividades, pois os agentes se tornam limitados a executarem apenas aqueles serviços autorizados pelos órgãos responsáveis, mesmo que tenham a habilidade para desenvolver outros.

Não diferente das outras cidades, em São José do Rio Preto vimos que as áreas próximas a hospitais e clínicas terminam por 
agregar lojistas, assim como atividades de manutenção de equipamentos médicos.

A existência de estudantes em cursos universitários de medicina, nutrição, veterinária, enfermagem, fisioterapia são mercados potenciais para o crescimento do varejo ligado aos equipamentos médicos. Da mesma forma, a ocorrência de cursos técnicos de operadores de equipamentos médicos, como técnico em radiologia, cria uma mão de obra na cidade que, podemos dizer, nem sempre empregada.

Ainda assim, tais cursos de formação técnica ou superior respondem ao aumento das clínicas de diagnóstico e terapia na cidade que, por sua vez, solicitam demandas de manutenção para os equipamentos médicos.

Vimos em São José do Rio Preto que ainda prevalece a assistência técnica aos equipamentos a partir de contratos de manutenção entre as empresas e os hospitais, públicos e privados, e clínicas. Diferentemente da densidade dos discursos sobre engenharia clínica e manutenção preventiva em Campinas, em Rio Preto parece haver maiores interstícios para serviços de manutenção autônomos.

Desse modo, as heranças de situações passadas e a dialética impressa pela refuncionalização dos eventos nos lugares revelam de que modo algumas cidades são oportunidades às topologias de grandes corporações e bancos, e ainda o lugar de produção e serviços mais ordinários.

Nas três cidades, diante da ação conjunta entre atores de diferentes forças, de origens diversas, de interesses variados, o projeto não é o mesmo. As diferentes divisões do trabalho implicam-se com maior ou menor grau de cooperação e conflito na realização das geografias contemporâneas.

0 entremeado de formas antigas e novas constitui uma socialidade que, funcional ao movimento do mundo, é a própria cidade tecida junta. Ainda mais quando o período atual está definido por uma imbricada interdependência entre os eventos.

Nesse sentido, as diferentes divisões territoriais do trabalho são expressão do meio construído que, diferenciado pelas suas qualidades sempre relativas, constitui níveis múltiplos de relação com o mercado. 
Entretanto, o discurso que almeja contar uma narrativa única do nosso tempo torna indistinto o que ignora. De outro modo, ignora para, com isso, contar uma certa história, cuja concepção da economia e do homem facilita que a diversidade se torne enredada em relações hierárquicas de dominação e dependência.

Não haverá novidade nisso. Mas o fato de que a cientificidade e organização dos processos da economia moderna vêm recriar e, ao mesmo tempo, cooptar as propriedades diferenciais dos agentes, torna a parcela técnica da produção um mecanismo de perpetuação do controle por parte da parcela política do trabalho.

Para observar como, nas cidades de Campinas, Ribeirão Preto e São José do Rio Preto, as atividades ligadas aos equipamentos médicos são incorporadas às novas correntes mundiais, desenhando novas geografias, orientamos nossa atenção para a variedade de usos do território.

o território é usado por diferenças, manifestando, assim, situações geográficas vivas, em que são definidos permanentemente, e de forma relacional, o circuito superior, sua porção marginal, e o circuito inferior da economia urbana.

A relevância da circulação no processo de diferenciação espacial implica no alargamento dos contextos dos agentes. À medida que as solidariedades se fazem ver pelos mecanismos que organizam novas hierarquias do acontecer dos lugares, a economia urbana se revela pela própria natureza do processo de diferenciação dos agentes e dos lugares.

Entender este processo a partir do poder do circuito superior, que requalifica os lugares em função de seus interesses hegemônicos, foi uma constatação da globalização como perversidade. Quando a técnica se mostra tão indissolúvel à estrutura da ação como no período atual, a saúde moderna convida à criação de formas de trabalho subordinadas, legitimadas graças à produção científica de formas de convicção social.

Isso se dá não apenas no consumo da saúde como bem coletivo, mas no modo de produzir da saúde. A lógica territorial de grandes empresas para tornar hierárquica a temporalidade de outros agentes e refazer suas hierarquias pela inovação se mostra por mecanismos hegemônicos, alguns mais invisíveis que outros. 
Enquanto isso, o sistema de saúde se gaba das modernizações sem se ater que as sabidas e aceitas dificuldades de acesso relacionadas à distribuição geográfica dos serviços têm outra natureza. O uso do território se oligopoliza e se fragmenta em função de topologias que não estão expressas na paisagem.

Diante das dificuldades e contradições que procuramos apresentar, a economia política que, nessas cidades, se revela entre os fornecedores, compradores, distribuidores de objetos para a saúde, manifesta o modo como a demandas são criadas pelas forças do período, mas como a existência se dá a partir dos lugares.

Ainda que as diferentes divisões territoriais do trabalho sejam tomadas como convêm ao exercício de interesses que provêm de outro lugar, o lugar abriga a sobrevivência de atividades que ocupam os interstícios da economia urbana. Enquanto a criação de novas hierarquias compartimenta o uso do território, níveis diferenciados de relação com o meio construído são convidados a uma solidariedade organizacional verticalizada. 


\section{Considerações Finais}

Os objetos médicos modernos conquistaram o país. E não é válido dizer que integram nossa cultura pelo simples poder de grandes corporações, pois nossa identificação com um patrimônio que nos permite a sobrevivência, como chamou Isnard (1982:30) o espaço geográfico, circunscreve esse realidade.

As técnicas constituem o espaço geográfico, pois que é uma realidade projectiva. Daí dizer que se o meio obriga o homem a descobrir potencialidades latentes, a saúde do homem, atributo sem o qual a vida não se realiza, é razão de agir. Santos (1996:137) nos ensina que "cada período é portador de um sentido partilhado pelo espaço e pela sociedade, representativo da forma como a história realiza a promessa da técnica”.

Nossa época se tornou mais complexa e diversa, e a interdependência e simultaneidade de eventos parece nos confundir tanto quanto desafiar. Como nos lembra Ribeiro (1993), a cultura na qual encontramos os motivos das nossas escolhas técnicas e políticas é hoje crescentemente manipulada.

Para quem a troca de produtos não é mais importante que a troca de pensamentos, Vallaux mostra com “é por essa circulação interespiritual que geralmente se translada a energia ativa das diferentes formas sociais e, em particular, dos Estados” (Vallaux, 1914:267). É nosso tempo vivido quem nos chama à visão crítica. Pois se temos hoje uma universalidade como totalidade empírica, o modo como as grandes corporações se realizam, transformando os atuais processos de diferenciação em hierarquias e desigualdades, insiste em esconder as possibilidades reais de uma globalização mais humana.

Da mesma forma, o modo como o Estado realiza a política mostra o peso das exigências do mercado e limita o que a define: uma visão ampla e de conjunto. Espinosa (1973) quando ensina em seu "Tratado Político" que todo direito é um poder, isto é, que nosso direito vai até onde temos poder para realizá-lo e força para garantir, inspira-nos a observar a saúde pela forma como o território é usado.

Sorre (1947) nos ensina sobre os fundamentos biológicos da geografia humana e, com ele, vimos a contribuição da disciplina geográfica no alcance científico da interpretação das doenças. 
Hoje, porém, a geografia do mundo é tornada mais complexa com o advento das técnicas da informação, alterando a natureza técnica e política das questões relacionadas à saúde das populações.

Embora condições endógenas não cessem de criar necessidades médicas e as tecnologias importadas sejam possibilidade do período, o âmbito da saúde moderna parece facilitar um certo discurso universal como fábula no exercício da globalização.

A ciência e tecnologia na saúde, proposta como engajamento político do país no atual universo da competitividade global, revela formas atualizadas de (sub)desenvolvimento, assim como expõe controvérsias na garantia desse bem coletivo.

Atentamos para o modo pelo qual a saúde hoje responde a uma lógica de organização e uso dos objetos geográfico. o meio geográficos constituído por crescente conteúdo de técnica, ciência e informação nos mostra que a saúde, enquanto fenômeno técnico, possui uma ordem técnica sobre a qual se instala uma ordem social planetária em benefício de poucos.

Isso não se realiza apenas pelas técnicas de ação desses gigantes globais, como a Siemens a GE Electric, mas também pelo que falta ao Estado quando não admite a diversidade de agentes não-hegemônicos que, respondendo a um mercado concreto de bens e serviços ligados a saúde, é capaz também de produzir riqueza.

Pudemos observar que a natureza dos sistemas de objetos e de ações contemporâneos revela intencionalidades das técnicas médicas, cuja compreensão pareceu estar mais além do que insiste a idéia de setor. A interpretação do fenômeno técnico, partindo do entendimento do território usado por uma variedade de divisões territoriais do trabalho fez aparecer a forca desigual dos agentes.

Vimos que o aumento da demanda por saúde não é apenas resultado da ampliação dos direitos sociais no país, mas do próprio meio técnico-científico e informacional. Nesse presente histórico em que os objetos tornam-se concretos, prenhes de intencionalidades e imperativos de regulação, demandas por saúde adquirem nova natureza.

A intrínseca relação atual entre a técnica e a estrutura da ação nos mostra que a economia moderna da saúde, assim como a organização dos serviços de saúde no país, demanda equipamentos 
médicos sempre mais modernos, compreendidos pelo poder de oligopólios do centro do sistema.

Daí que as modernizações imprimam uma dinâmica territorial de renovação técnica e normativa que, acelerada por demandas particulares, termina por valorizar apenas alguns agentes da produção e, por sua vez, do consumo de equipamentos médicos na cidade.

Desse modo geral, o Brasil, apesar de possuir uma indústria capaz de suprir o mercado interno com a diversidade de produtos de que precisam os serviços de saúde, termina por criar necessidades tecnologias tão sofisticadas, cuja satisfação é externa.

Nesse mesmo passo, a produção nacional de equipamentos médicos se torna cada vez mais vulnerável aos enquandramentos que respondem ao crescimento do comércio e competitividade internacionais e, com efeito, à aceleração da criação de densidades normativas.

As dependências que se revelam na vulnerabilidade dos serviços de saúde, em relação à ampliação da demanda e às condições materiais e organizacionais do sistema, parecem explícitas. Nem tão evidentes são os mecanismos renovados de segmentação do mercado e oligopolização da esfera produtiva dos equipamentos médico-hospitalates.

A cidade, vista pela justaposição de divisões territoriais do trabalho, mostrou-nos como a saúde moderna possui papel na diferenciação dos lugares. Igualmente, a cidade, vista pelas relações entre a materialidade e o movimento da sociedade, mostrou-nos que as modernizações em saúde respondem à dinâmica mais ampla da urbanização brasileira.

Como dissemos, buscamos compreender esse fenômeno técnico pela análise da nova geografia que se mostra no processo de divisão do trabalho. Nesse sentido, verificamos três momentos dessa constituição: a constituição dos oligopólios, o papel ativo do território na difusão das inovações e a multiplicação das atividades impuras.

A verificação a respeito das atuais políticas de desenvolvimento industrial relacionadas à saúde, como os programas de Arranjos Produtivos Locais, ou mesmo o Complexo 
Industrial da Saúde, se apresentou como importante via de compreensão da dinâmica produtiva nacional.

Por serem eventos significativos na nossa análise, os quais perpassam três níveis de solidariedade: o mundo, a formação socioespacial e o lugar, estes eventos constituem a definição das situações geográficas nas cidades de Campinas, Ribeirão Preto e São José do Rio Preto.

Nesse sentido, quando damos atenção a compreensão do acontecer solidário nessas cidades, as mediações se tornam visíveis nos lugares. A escala, dada em função das temporalidades práticas dos diferentes agentes, mostra que idéia de hierarquia de escalas no território se dissolve diante da complexidade de fenômenos que são expressão da variedade de formas de existência.

As políticas de saúde, de desenvolvimento produtivo, de ciência e tecnologia, e o modo como as cidades realizam tais projetos contribuíram, portanto, para nossa perspectiva empírica das formas de sobrevivência encontradas pelos diferentes agentes da economia urbana.

o processo de cientifização do trabalho e, em particular, ligado aos equipamentos médicos, se realiza por um papel das instituições. Com Gaudin (1978:64), entendemos instituição como noção próxima à organização, isto é, não no sentido jurídico, mas "daquele que se define se instituindo".

Por veicularem publicações, notas, relatórios, atos, status (Gaudin, 1978), as instituições têm o poder de se auto-instituir ao produzir seu próprio discurso. Nesse sentido, não mencionamos apenas o Estado no que tratamos como obsolescência técnica e política das formas de trabalho relacionadas com os objetos médicos.

Mas também a instituição médica, que difunde sempre novos protocolos de procedimentos; as grandes corporações, por exemplo, com os empenhos em pesquisa e desenvolvimento ou em marketings; entre outras, como entidades de classe, bancos, consultores.

Pudemos observar uma lógica subjacente aos comportamentos institucionais desses atores no que diz respeito ao nosso tema de pesquisa. Atentamos aos seus comportamentos pelos seus interesses revelados diante do modo como a globalização é produzida. 
Nesse sentido, vimos que, nesse âmbito ligado aos equipamentos médicos, a cientifização do trabalho e informatização do território revelam o meio pelo qual essas instituições definem o escopo das possibilidades de atores nãohegemônicos e terminam por confiscar a força que têm para produzir saúde.

Essas modernizações técnicas e políticas mostraram que, graças ao aumento da divisão do trabalho, o circuito superior marginal ligado aos equipamentos não apenas existe, como se alarga. Expressão da relevância da circulação no período atual, - sistema produtivo desses objetos médicos irá contar com uma multiplicação de atividades, em que o trabalho se realiza por cooperação e conflito.

Outrossim, a manutenção desses equipamentos de saúde se revelou com relevo na caracterização dos circuitos da economia urbana. As necessidades atualizadas de manutenção dos aparelhos mostraram novos nexos de interdependência entre as diferentes formas de trabalho. Advindos da terceirização que não pára de crescer e, da mesma forma, de mecanismos técnicos e políticos do circuito superior puro confiar tarefas à sua porção marginal, o circuito superior marginal pôde ser observado.

As diferentes situações de existência nas quais estão envolvidas as atividades ligadas aos equipamentos médicohospitalares nas cidades de Campinas, Ribeirão Preto e São José do Rio Preto se tornaram expressas pelos circuitos da economia urbana.

o território usado por uma variedade de agentes revela que atividades de diferentes graus de capital, tecnologia e organização se comunicam por diferentes circuitos de produção, deixando evidentes suas capacidades para dar valor a seus produtos.

$\mathrm{Na}$ medida em que a saúde se torna tema estratégico ao desenvolvimento do país, pudemos observar na situação geográfica definida em Ribeirão Preto que a produção desse novo arranjo na cidade a revela por uma concretude territorial (Silveira, 1997), responsável por alargar e densificar, de uma só vez, o acontecer do lugar.

Definidas na construção de um meio perfeito, "resultado da convergência entre as funções planejadas e as funções 
desenvolvidas nos lugares” (Silveira, 1997:43), as atividades da cidade são modernizadas por um intenso processo de cientifização do trabalho e do território.

Mas se quanto maior e mais populosa a cidade, maior a complexidade dos circuitos da economia urbana que ali se entrecruzam, Campinas se deixou observar pela diversidade das formas de trabalho vinculadas aos equipamentos médicos. Já Rio Preto revelou circuitos relativamente menos densos e complexos.

Podemos dizer que é, sobretudo, pela densidade técnica e informacional (Santos, 1996:205) dessas cidades e a produtividade espacial que apresentam à saúde moderna, que um processo de racionalização encontra nesses lugares um caminho à inserção na atual divisão internacional do trabalho.

o conteúdo técnico científico e informacional que atualmente define a saúde nessas cidades dirige 0 interesse para transformá-las, além do que já são, em formas adequadas para responder aos imperativos da competitividade e as demandas de agentes hegemônicos.

A inserção desses subespaços na divisão interna e internacional do trabalho é parte de um processo maior, a internacionalização dos circuitos da economia urbana. Assim, a racionalidade que envolve essa modernização, material e organizacional, ligada aos equipamentos médicos nas cidades expressou-se por uma aceleração normativa.

Às atividades de fabricação é exigida severa adequação às regras e padrões internacionais de qualidade, sendo que a certificação dos produtos e das empresas se tornou grande medida dos níveis de tecnologia, organização e capital dos agentes.

Nesse sentido, o fio que definiria a sobrevivência da empresa mostrou não responder apenas pela natureza dos desígnios do mercado, mas pelas intencionalidades do Estado. As normas como motor da diferenciação da divisão do trabalho relacionada aos equipamentos médicos se mostrou dominante na existência do circuito superior marginal.

Entretanto, pela especificidade desses objetos constituirem os serviços de saúde e, em última instância, servirem à vida, a norma não é o que assusta os produtores nacionais. 0 que se 
mostrou determinar o comportamento do circuito superior marginal foi a velocidade.

Isto é, a velocidade cuja aceleração responde ao ritmo da competitividade global. Nesse sentido, apesar das normas que buscam amplamente meios de qualificar os objetos, a violência do que termina por qualificar os agentes não responde à norma, mas sobretudo, à velocidade impressa pelo modo como o Estado desenha sua forma de integrar à competitividade das empresas hegemônicas.

Criador das próprias variáveis-força do período, o circuito superior dos equipamentos médicos mostrou de que modo segmenta o mercado enquanto território, valendo-se dos lugares, isto é, das condições preexistentes e de vantagens construídas, para o exercício de mecanismos verticalizados capazes de extrair o excedente de um trabalho unificado à escala do globo.

A formação socioespacial brasileira é, nesse sentido, tomada como plataforma econômica de difusão de sistemas de objetos e de ações médicos, não apenas no mercado interno, mas no continente latinoamericano. Enquanto o sistema dos serviços de saúde do país revelou ser consoante com a projeção desses atores hegemônicos.

0 Estado, enquanto o agente da mediação dos interesses do mercado e da nação, mostrou dispor o uso do território, segmentando-o enquanto mercado. A produtividade espacial de Campinas, Ribeirão Preto e São José do Rio Preto para uma economia da saúde reuniu nessas cidades oportunidades à realização do capital hegemônico.

Daí a observação de que o acontecer dos lugares, ao se tornar solidário num movimento unificado à escala do planeta, mostra a presença generalizada com que a globalização se faz profunda e eficaz a partir dos lugares.

À medida que as variáveis-força difundem o sistema técnico, estendendo-o como suporte do período, a economia urbana se torna mais densa e complexa. Nesse sentido, vem permitir que novos nexos sejam integrados aos subsistemas hegemônicos, onde uma variedade de novas atividades cresce, diversificando a economia urbana. 
Hoje, podemos dizer que, sobretudo, Ribeirão Preto, passa por um acelerado processo especialização produtiva. 0 Estado, através do planejamento, exerce seu poder para criar as condições materiais e organizacionais de um território mais fluído. Da mesma forma, a cidade veio mostrar o papel que hoje tem a circulação nas transformações das hierarquias urbanas.

Lembramos Jean Gottman ao valorizar a circulação por sua natureza política e não apenas econômica. Esse mecanismo de ação regulada, pois, vem atualizar a integração da cidade na nova divisão internacional do trabalho, por meio da substituição de uma divisão do trabalho, por outra mais moderna.

De modo geral, é a velocidade com que esse novo subsistema hegemônico se instala que cria novos contornos da vulnerabilidade que define o circuito superior marginal. Nessa direção, o sistema de serviços de saúde no país possui uma concepção e operação hierárquica da oferta de serviços em função do nível de complexidade médica. Desse aspecto formal, acrescentamos que os equipamentos médicos, por não se tornarem necessariamente obsoletos com a chegada de um novo, permitem a convivência de objetos de várias idades.

Todavia, embora quase a totalidade da produção nacional de equipamentos médicos sirva ao mercado interno, ainda que haja demandas pela produção de objetos menos complexos e que o circuito superior não se preocupe em ocupar todos os mercados, é pela aceleração e densidade normativas que a capacidade de produzir e consumir de muitos agentes se torna comprometida.

No entanto, se por um lado um circuito superior marginal residual se amplia pela incapacidade de acompanhar o ritmo das modernizações, por outro, a expansão dos consumos, o caráter científico das atividades, a precedência do trabalho intelectual são demandas ao crescimento de um circuito superior marginal emergente.

A natureza mista do circuito superior marginal - próximo do circuito superior pela funcionalidade do trabalho e um comportamento que o aproxima do circuito inferior - mostra que o aumento da divisão do trabalho ligada aos equipamentos médicos cria estímulos tão perecíveis quanto se renovam permanentemente.

Por isso, como mostra Santos (1979), vimos que não é possível entender que haverá uma demanda específica que define o circuito 
superior marginal. Não se trata de um terceiro circuito ou intermediário, pois, como porção marginal do circuito superior, sua existência é o efeito diferenciado do movimento de incorporação desigual das variáveis do período.

Suas atividades, nesse sentido, tornaram significativas as condições locais do mercado como dados concretos do modo como as atividades econômicas e sociais se realizam. Daí podermos dizer, da mesma maneira, que o circuito superior marginal dos equipamentos médicos não revelou uma forma topológica que o defina.

Pois a cada modernização do circuito superior, a cada divisão do trabalho que se instala sobre o que preexiste, os agentes de um circuito superior marginal têm que encontrar os interstícios de seu abrigo na cidade.

A modernização técnica e normativa que vimos relacionada aos equipamentos médicos imprime ao circuito superior marginal a decodificação dos novos objetos e normas representativas do novo momento do modo de produção. Daí a situação geográfica em Ribeirão Preto ter se revelado também como oportunidade a um grande número de agentes.

Por meio de atividades desenvolvidas pela gestão do Arranjo Produtivo Local, como acessória aos agentes na confecção de projetos, palestras como com o Instituto de Política Tecnológica, seminário de capacitação com consultores para competitividade, de empreendedorismo com o SEBRAE, encontros para agilizar atrasos com a ANVISA.

Ao passo em que a cidade vem abrigar um novo elenco de funções científica e tecnicamente fundadas, criando as condições intencionadas de um novo tempo social global, pudemos reconhecer a dialética do território tornada expressa pelo próprio comportamento do circuito superior marginal.

Os vetores modernos, sendo, por natureza, seletivos, criam dependência e escassez da mesma forma que permitem uma variedade de novas atividades e oportunidades de trabalho, diversificando e densificando a economia urbana. O Estado nos mostra que é também criador de novos interstícios na trama econômica da cidade. 
Assim, ainda que algumas atividades sejam deixadas morrer, há demanda que não para de crescer, seja pelos aspectos sistêmicos da técnica, seja pela vocação do consumo que se difunde. E permite que outras atividades surjam, pela decadência ou emergência de profissões e empresas.

Talvez por isso as empresas nacionais mais antigas se revelaram como aquelas mais consolidadas, com maior número de funcionários, com mais capacidade para lidar com as mesmas modernizações que atormentam os agentes mais vulneráveis.

À medida que esse novo sistema temporal organiza e transforma nosso meio geográfico, cresce e torna mais complexa as atividades de um circuito superior marginal vinculado aos objetos médicos. Vimos, pois, que este, por sua vez, ocupa-se de interstícios da economia urbana ou se realiza por completar o trabalho de agentes hegemônicos.

Essa definição mista do circuito superior marginal se apresentou por diferentes formas de trabalho, entretanto, revelou também poder acontecer ao mesmo tempo. Haverá uma diferença de natureza entre o interstício da manutenção de termômetros hospitalares de mercúrio, e as manutenções autorizadas, inscritas tanto na organização das grandes empresas como no contexto das necessidades dos lugares.

Quando a manutenção de equipamentos médicos nos chamou atenção por serem serviços técnicos que exigem certa proximidade física do objeto, essas atividades revelaram mecanismos hegemônicos de criação de hierarquias e escassez.

Nesse sentido, a manutenção, crescentemente demandante de técnica ciência e informação, torna-se codificada por um discurso da eficiência e qualidade que se vale da "vida" para promover a transformação de marcas em mecanismos que engendram uma oligopolização da economia urbana. Tecnoesfera e psicoesfera são, assim, indissociáveis.

A observação desses mecanismos de cooperação, renovados enquanto nexos de subordinação de atividades locais aos interesses hegemônicos, foi de grande relevância para perseguirmos como se mostra o circuito superior marginal. 0 circuito superior, valendo-se das variáveis tornadas dominantes, usa o território a partir da vida de relações que perfaz a existência das atividades de manutenção na cidade. Tais 
atividades, nascidas em razão da economia de aglomeração relacionada à saúde desses lugares, servem e são servidas por um acontecer que se sincroniza.

A dimensão do acontecer hierárquico mostra como, pela manutenção crescentemente científica, atividades locais servem a uma solidariedade coordenada da produção globalizada, da mesma forma que é servida pelo alargamento de seu contexto pelo aumento de da escala de ação. Tratar-se-ia de um equilíbrio da penúria (Santos, 1981) das indústrias-serviços, em uma de suas formas atuais.

Vimos que peças de reparo, próprias das especificidades dadas pela marca do aparelho, são destinadas a proteger a originalidade da fabricação, mas, sobretudo, controlar a política organizacional sobre as firmas subalternas.

Mas também, controlar seu mercado em relação aos concorrentes, pois enquanto as garantias de serviços pós-venda asseguram que agentes locais mantenham as relações com os clientes, essas grandes empresas realizam seus empenhos em pesquisa e desenvolvimento, até que um objeto novo seja lançado.

Ainda, a indisponibilidade para estas empresas de manutenção fazerem estoques de aparelhos ou partes são manifestação dessa hierarquização como modo de criação de escassez. Esse processo de subjugo da capacidade produtiva da cidade pareceu-nos forma bem acabada do poder de produção da escala de império, assim como o papel do circuito superior marginal nesse processo de oligopolização da economia urbana.

Nesse sentido, foi possível observar quanto às atividades de manutenção e também de fabricação que a capacidade de organização é fator de definição dos circuitos econômicos relacionados aos equipamentos médicos. Porém, para a produção de bens, o nível de organização é correspondente ao nível de capitalização e tecnologia, enquanto que para os serviços, essas relações mútuas não pareceram tão estreitas.

Nessa direção, como resposta sistêmica à involução metropolitana, o circuito superior marginal nessas cidades, fruto da segmentação da economia urbana enquanto esta supre as demandas por empregos e serviços, é também um entrave à expansão da oligopolização contemporânea. 
A existência de circuitos diferenciados de produção e consumo é já resultado de uma expressão da luta diante das desigualdades, revelando o lugar de cada um na cidade. E quando essa diferença se torna retransformada por esses mecanismos de verticalização solidária, parece revelar a reprodução da pobreza, tornada estrutural, como observou Santos (2000:72).

Refém de regras técnicas e modelos de desenvolvimento engendrados por aqueles que comandam a produção e difusão dos equipamentos médicos, reproduzimos uma economia urbana que embora multiplique o emprego e as condições de existência, não parece capaz de transformar desenvolvimento em liberdade.

Nessa mesma medida, ainda, esse processo revela que se trata de uma racionalidade que não se completa sem que o circuito superior marginal seja tomado por uma racionalidade subordinada. Esse reconhecimento nos aproxima da percepção dos circuitos da economia como vasos comunicantes.

Nesse sentido, o circuito superior marginal se mostrou por sua vulnerabilidade, mas também pelo sentido que seu trabalho encontra nos contextos a que pertence. 0 acontecer complementar e homólogo, isto é, as relações entre as cidades e a generalização da informação, ambos efeitos das modernizaçõese capazes de criar um grau de cooperação na contiguidade, respondem às forças localmente centrípetas.

Aqui, o território local, constituído como norma pela forma que se organizam os padrões de modernização dos serviços de saúde, é uma força centípeta à realização das atividades de um circuito superior marginal. Como é no nível local que vemos uma dialética entre os dois circuitos da economia urbana - o circuito inferior e o circuito superior - a observação do circuito superior marginal dos equipamentos médicos nas cidades mostrou que é capaz de representar dois tipos particulares de relação com sua região.

Na dependência de insumos simplificados para a fabricação de equipamentos, na manutenção de equipamentos em cidades vizinhas, essas atividades mostraram de que modo o circuito inferior se relaciona com a porção marginal do circuito superior pela produção e pelo consumo dos equipamentos médicos.

Nesse sentido em que a proximidade tem um papel na realização no mundo, não nos pareceu arriscado refletir sobre a realização 
do circuito superior marginal relacionando-o com as duas áreas de influência da cidade, como explicara santos (1979) os circuitos na constituição de subsistemas do sistema urbano.

Daí a natureza de sua forma de resistir à oligopolização da economia, ou seja, a constituição técnica e política do território usado e as diferentes demandas a serem supridas. Eis porque insistimos observar cada cidade enquanto materialidade e ação simultaneamente.

Pois a escassez enquanto divisão territorial do trabalho não hegemônico torna-se imperativa contra-finalidade numa dinâmica criativa na produção da interdependência do trabalho. Admitimos tal perspectiva quando vemos as atividades pelos seus sítios e contextos específicos na cidade.

Desse modo a cooperação se revelou ser um conceito plural, pois, as divisões territoriais do trabalho em suas diferenças não são apenas resultados, mas condições que estabelecem relações de interdependência como combinação de diferentes oportunidades de uso do território.

Santos (1996:254) quando nos diz que a relação do sujeito com o prático-inerte inclui a relação com o espaço parece nos apontar o meio construído urbano como elemento da condição à sobrevivência de um grande número de formas de trabalho. Nesse sentido, é o lugar que realiza a mediação entre o sujeito e o mundo.

A cooperação enquanto conceito plural, assim como a divisão do trabalho, vimos, também o é, revela em que medida o meio construído, diferentemente valorizado para produzir e consumir, é fundamento da realização do fenômeno social total, isto é, o acontecer solidário, malgrado todas as formas de diferença entre pessoas, entre lugares.

Por um lado, o processo de modernização vinculado à saúde nos mostra as diferenças no impacto do modo de produção sobre os lugares, regiões e países. Por outro, o circuito superior marginal relacionado aos objetos médicos, sua existência e caracterização, revelou o papel do meio construído ao expor sua complementaridade do trabalho que se oferece aos serviços de saúde do país.

Nesse movimento de tecnificação da medicina, a forma como os lugares são usados revela a força de influência sobre o modo 
como as atividades econômicas e sociais da saúde são produzidas. Como nos ensina Santos (1996) o novo não poderá ser confundido com o moderno.

O estudo sobre as cidades de Campinas, Ribeirão Preto e São José do Rio Preto, observadas pelo modo como se constituem material e organizacionalmente em relação às atividades dos equipamentos médico-hospitalares, e a urbanização, observada pelo modo como se realiza enquanto fenômeno espacial, puderam apontar a inseparabilidade desse processo.

Os circuitos da economia urbana para a saúde foram instrumento de compreensão de alguns dos processos de interdependência e fragmentação que caracterizam a urbanização no período atual, enquanto a economia urbana, vista pelos níveis de integração e subordinação foi capaz de revelar, também, outras combinações possíveis. 


\section{Bibliografia}

AGENCIA BRASILEIRA DE DESENVOLVIMENTO INDUSTRIAL. Panorama setorial: Equipamentos médicos, hospitalares, odontológicos, ABDI, Brasília, 2008.

ALBUQUERQUE, E.M; CASSIOLATO, J.E. "As Especificidades do Sistema de Inovação do Setor da Saúde”. In: Revista de Economia Política, v. 22, n. 4 (88), out-dez, 2002.

ALMEIDA, E. P. Uso do território brasileiro e os serviços de saúde no período técnico científico informacional. Tese (Doutorado em Geografia Humana)Faculdade de Filosofia Letras e Ciências Humanas/ Universidade de São Paulo. São Paulo, 2005.

ANDRADE, M. C. Espaço. Polarização e Desenvolvimento: uma introdução à Economia Regional. 5. ed. Editora Atlas S.A. São Paulo, 1987.

ARROYO, M. M. Dinâmica territorial, circulação e cidades médias. In: SPOSITO, E S.; SPOSITO, M E B; SOBRAZO, O (Org), Cidades Médias: produção do espaço urbano e regional. São Paulo: Expressão Popular, 2006.

, M. A economia invisivel dos pequenos. In: Le Monde Diplomatique Brasil, out. 2008.

AUguSto, M.H.O. "Reflexões sobre o Uso das Tecnologias Médicas". In: CANESQUI, A.M. Ciências Sociais e Saúde para o ensino médico. Editora Hucitec, São Paulo, 2000.

BAUDRILLARD, J. O sistema dos objetos. Editora Perspectiva, São Paulo. [1968] 1973.

BAUMAN, Z. Medo Líquido. Tradução: Carlos Alberto Medeiros. Rio de Janeiro, 2008.

BENKO, G. La ciencia regional: Traducción: Roberto Bustos Cara. Universidad Nacional del Sur. Bahía Blanca, 1999.

, G; LIPIETZ, A; As Regiões Ganhadoras. Distritos e redes: os novos paradigmas da geografia econômica. Tradução: Antônio Gonçalves. Celta Editora. Oeiras, 1994.

BERnARDES, A. A Presença do Velho e do Novo na Cidade de São Paulo. o Caso das pequenas e médias indústrias não hegemônicas. In: Revista Experimental, n.1. p. 13-20, julho, 1996.

A. "A nova divisão territorial do trabalho brasileira e a produção de informações na cidade de São Paulo (as empresas de consultoria)". In: o Brasil - Território e Sociedade no início do século XXI. SANTOS, M. e SILVEIRA, M. L. Editora Record, Rio de Janeiro, 2001, p. 413-432.

BICUDO JUNIOR, E. C. O circuito superior marginal: produção de medicamentos $e$ o território brasileiro. Dissertação de Mestrado em Geografia Humana, FFCH/ USP. São Paulo, 2006.

BITTAR, O. N. V. "Produtividade em hospitais de acordo com alguns indicadores hospitalares", em: Revista de Saúde Pública, v.30 n.1, fev. São Paulo, 1996. 
BANCO NACIONAL DO DESENVOLVIMENTO - Setorial - Complexo Industrial da Saúde: insumos e equipamentos de uso médico. Rio de Janeiro, n. 19, p. 119-155, mar. 2004.

BOBBIO, N. A Era dos Direitos, Campus, Rio de Janeiro, 1992.

BOUSQUAT, A. "Conceitos de espaço na análise se políticas de saúde", In: Revista Lua Nova, n.52. São Paulo, 2001.

CALIL, S. "Análise do setor de saúde no Brasil na área de equipamentos médico-hospitalares." In: Negri, B. e Di Giovanni, G. Brasil: radiografia da saúde. Ed. IE/Unicamp Campinas, 2001.

CAMPOS, G.W.S. "O SUS entre a tradição dos Sistemas Nacionais e o modo liberal-privado para organizar o cuidado à saúde’. In: Ciência e Saúde Coletiva, 12(Sup): 1865-1874, 2007.

CANCLINI, N. G. Consumidores e Cidadãos: conflitos multiculturais da globalização. Tradução: Maurício Santana Dias. 7. ed. Editora UFRJ, Rio de Janeiro, 2008.

CANGLUILHEM, G. Escritos sobre a Medicina. Ed. Forense Universitária, Rio de Janeiro, 2005.

CAPANEMA, L.X.L.; FILHO PALMEIRA, P. L.; PRIEONI, J. P. Apoio do BNDES ao Complexo Industrial da Saúde: a experiência do Profarma e seus desdobramentos, em: BNDES Setorial, n.27, p.3-20, mar. Rio de Janeiro, 2008.

CARIOLA, C. e LACABANA, M. “La metrópoli fragmentada. Caracas entre la pobreza y la globalización”. In: Eure, Santiago, v.27, n.80, maio, Santiago, 2001.

CHAUÍ, M. Cultura e Democracia: o discurso competente e outras falas. 3 . ed. Editora Moderna. São Paulo, 1982.

M. Espinosa: uma filosofia da Liberdade. 2. ed. Editora Moderna. São Paulo, [1995], 2006.

CHOLLEY, A. "Observações sobre alguns pontos de vista geográficos." In: Boletim Geográfico, Fundação Instituto Brasileiro De Geografia e Estatística, n.180, 1964

COHN, A. "O Sistema Único de Saúde: a síndrome da dualidade”, em Revista USP, $\mathrm{n}^{\circ}$ 51, set./nov, pp. 6-15, Dossiê Saúde, 2001.

CONTEL, F. B. Espaço geográfico, sistema bancário e hipercapilaridade do crédito. Caderno CRH, v.22, n.55, p119-134, jan./abr, Salvador 2009.

CORDEIRO, H. As empresas médicas. Edições Graal, Rio de Janeiro, 1984.

CORREA, R. L. Estudos Sobre a Rede Urbana. Bertrand Brasil, Rio de Janeiro, 1988.

R. L. Trajetórias geográficas. Bertrand Brasil, Rio de Janeiro, [1996] 2005.

COSTA, N.R; RIBEIRO, J.M; SILVA, P.L.B. "Reforma do Estado e mudança organizacional: um estudo de hospitais públicos”. In: Ciência e Saúde Coletiva, 5 (2): 427-442, 2000.

CREUZ, V. o direito à voz no território - circuitos da economia urbana e a produção musical nas cidades de São Paulo, Porto Alegre, Rio de Janeiro 
e Goiânia. Trabalho de Graduação Individual, Universidade de São Paulo, 2008.

DAGNINO, R. "As Perspectivas da Política de C\&T”. In: Ciência e cultura $(S B P C)$, v. 59, p. 39-45, 2007.

DAVIDOVICH, F. “Urbanização Brasileira: tendências, problemas e desafios”. In: NERU - Núcleo de Estudos Regionais e Urbanos. Repensando o Brasil pós-60: as mudanças na dinâmica urbano-regional e suas perspectivas. Neru. São Paulo, 1984.

F.; FREDRICH, O. B. L. "A configuração espacial do sistema urbano brasileiro como expressão no território da divisão social do trabalho”, em: Revista Brasileira de Geografia, 44(4), IBGE, Rio de Janeiro, outdez, p. 541-590, 1982.

DIAS, L.C. "Redes: emergência e organização”. In: CASTRO, I.E; GOMES, P.C.C; CORRÊA, R. (Org.), Geografia: conceitos e temas. Editora Bertrand Brasil. 2001

ELLUL, J. A Técnica e o Desafio do Século. Tradução: Roland Corbisier. Editora Paz e Terra. Rio de Janeiro, 1968.

FARIAS, L. 0.; MELAMED, C. "Segmentação de mercados da assistência à saúde no Brasil”, em: Saúde \& Ciência Coletiva, 8(2): 585-598, 2003.

FEL, A. "La géographie et lés techniques". In: Gille, B (org.) Histoire des Techniques, Encyclopédie de la Pléiade, Paris, 1978.

FRIEDMANN, G. Sete estudos sobre o homem e a técnica. Ed. Difusão Européia do Livro, São Paulo, 1968

FouCAULT, M. o Nascimento da Clínica. Tradução: Roberto Machado. 6 . ed. Forense Universitária. Rio de Janeiro, 2008.

FURTADO, A. T. "Novos Arranjos Produtivos, Estado e Gestão da Pesquisa Pública”. In: Cienc. Cult. vol. 57. n.1. São Paulo. Jan./Mar. 2005.

FURTADO, A. T. e SOUZA, J. H. "Evolução do setor de insumos e equipamentos médico-hospitalares, laboratoriais e odontológicos no Brasil: a década de 90” em: Negri, B. e Di Giovanni, G. (org.) Brasil: radiografia da saúde. Campinas: IE/Unicamp, 2001.

FURTADO, C. O mito do desenvolvimento econômico. Ed. Paz e Terra, Rio de Janeiro, 1974.

GADAMER, H-G. O Caráter oculto da saúde. Tradução: Antônio Luiz Costa. Editora Vozes. Petrópolis, 2006.

GADELHA, C.A .G. "O Complexo industrial da saúde e a necessidade de um enfoque dinâmico na economia da saúde”. In: Ciência \& Saúde Coletiva, 8 (2): 521-535.

C.A .G; QUENTAL, C; FIALHO, B.C. "Saúde e inovação: uma abordagem sistêmica das indústrias de saúde’. In: Caderno de Saúde Pública, Rio de Janeiro, 19 (1): 47-59, jan-fev, 2003.

GAUDIN, T. L'ecoute des silences, lés institutions contre L'innovation?, Union Générale des Éditions, Paris, 1978.

T. Economia Cognitiva: uma introdução. Tradução: Paulo Anthero S. Barbosa. São Paulo: Beca Produções Culturais, 1999. 
GEORGE, P. Geografia Industrial do Mundo, 3. ed. Difel, São Paulo, 1973. P. L'ère des techniques, constructions ou destructions?, Presses Universitaires de France. Paris, 1974.

GODELIER, M. Racionalidade e irracionalidade na economia. Tempo Brasileiro, Rio de Janeiro, [1966] 1973.

GOMES, L.C.N. e DALCOL, P.R.T. "Estratégias de produção na indústria de equipamentos médicos de diagnóstico por imagem - uma análise da ressonância magnética”, em: Revista Produção on Line, Universidade de Santa Catarina, vol.7, n.1, abr. Florianópolis, 2007.

GotTMAN, J. La Politique des États et Leur Géographie. Paris, Librairie Armand Colin, 1952, p. 160-225.

GRANGER, G. G. A Ciência e as Ciências. São Paulo: Unesp, 1994.

GRIMM, F.C.A. Uso do território e coexistências de empresas de refrigerantes no Brasil. Dissertação de Mestrado em Geografia Humana, FFCH/ USP. São Paulo, 2002

GUGLIELMO, R. "A Geografia Ativa da Indústria”. In: GEORGE, P; GUGLIELMO, R; LACOSTE, Y; KAYSER, B. A Geografia Ativa. Tradução: Gil Toledo, Manuel Seabra, Nelson de La Corte. 3. ed. Difusão Européia do Livro. São Paulo, 1966.

GUIMARÃES, R. "Bases para uma política nacional de ciência tecnologia e inovação em saúde”. In: Ciência \& Saúde Coletiva, 9(2):375-387, 2004.

GUIMARÃES, R. B. "Saúde pública na América latina: questões de geografia política”. In: LEMOS, A. I. G; SILVEIRA, M. L.; ARROYO, M. (Org), Questões territoriais na América Latina. Buenos Aires-São Paulo: CLACSO/USP, p. 249-260, 2006.

R. B. "Serviços de Saúde, circuitos econômicos e cadeias produtivas”. In: Caderno Prudentino de Geografia, Presidente Prudente, n.21, p.17-24, jul. 1999.

R. B. "Regiões de saúde e escalas geográficas”. In: Caderno de Saúde Pública, Rio de Janeiro, 21 (4): 1017-1025, jul-ago, 2005.

GUtierREZ, R. M.; ALEXANDRE, P. V. M. Complexo industrial da saúde: uma introdução ao setor de insumos e equipamentos de uso médico, em: BNDES Setorial, Rio de Janeiro, n.19, p. 119-155, mar. 2004.

HABERMAS, J. Técnica e Ciência como Ideologia. Edições 70. Lisboa, [1968] 2006.

HAGERSTRAND, T. Innovation diffusion as a spacial process. Tradução: Allan Pred. Chicago, University of Chicago Press, 1967.

HARDT, M. Gilles Deleuze: um aprendizado em filosofia. Tradução: Sueli Cavendish. - São Paulo: Ed. 34, 1996.

HARVEY, D. "O trabalho, o capital e o conflito de classes em torno do ambiente construído nas sociedades capitalistas avançadas”. In: Espaço $e$ Debates, n. 6, p. 7-35, 1982.

IBAÑEZ, N. et al. "Organizações sociais de saúde: o modelo do Estado de São Paulo”, em: Ciência \& Saúde Coletiva, 6(2):391-404, 2001. 
, N; NETO, G.V. "Modelos de Gestão e o SUS". In: Ciência e Saúde Coletiva 12 (Sup): 1831-1840, 2007.

ILLICH, I. A Expropriação da Saúde: nêmesis da medicina. Tradução: José Kosinski de Cavalcanti. 2. ed. Rio de Janeiro, 1975.

INSTITUTO BRASILEIRO DE GEOGRAFIA E ESTATÍSTICA. Urbanização e regionalização, relações com o desenvolvimento econômico. Faissol, E. (Org.), Rio de Janeiro, 1975.

INSTITUTO BRASILEIRO DE GEOGRAFIA E ESTATÍSTICA. Regiões de Influência das Cidades - 2007. Rio de Janeiro, 2008.

INSTITUTO BRASILEIRO DE GEOGRAFIA E ESTATÍSTICA. Indicadores Sociodemográficos e de Saúde no Brasil. Rio de Janeiro, 2009.

INSTITUTO DE PESQUISA TECNOLÓGICAS DO ESTADO DE SÃO PAULO. Uma agenda de competitividade para a indústria paulista equipamentos médicohospitalares e odontológicos. São Paulo, fev. 2008.

IOZZI, F. e ALBUQUERQUE, M. V. "Saúde e Desenvolvimento na formação socioespacial brasileira”. In: Saúde, Desenvolvimento e Território. In: d’Avila Viana, A. L.; Ibañez, N.; Elias, P. E. (Org.) Saúde Desenvolvimento e Território, 2009, p. 60-95

ISNARD, H. O espaço geográfico. Coimbra: Almedina, 1982.

LABASSE, J. "A Procura de um Quadro Regional”. In: Boletim Geográfico. n. 199, ano: 126 - jul-ago. Rio de Janeiro, 1967.

, J. La ciudad y el hospital - geografia hospitalaria. Instituto de Estudios de Administración Local, Madrid, 1982.

LA BLACHE, P. V. Princípios de Geografia Humana. 2. ed. Cosmos, Lisboa, [1918] 1954, p. 1-45.

LABINI, P. S. Oligopólio e Progresso Técnico. Tradução: Vittoria Cerbino Salles. 3. ed. Nova Cultural. São Paulo, 1988.

LATOUR, B. Jamais fomos modernos: ensaio de antropologia simétrica. Tradução: Carlos Irineu da Costa. 2. ed. Editora 34. Rio de Janeiro, [1994] 2000.

LIPOVESTKY, G. A Era do Vazio. Tradução: Therezinha Monteiro Deustch. Manole. Barueri, [2005] 2009.

MABOGUNJE, AKIN L. Urbanization in Nigeria. University of London Press, New York, [1969] 1971.

MAMIGONIAN, A. "A localização industrial no Brasil”. In: Boletim Paulista de Geografia, n.51, São Paulo, p. 83-86.

MERLEAU-PONTY, M. Elogio da Filosofia. Tradução: António Braz Teixeira. 5.ed. Lisboa, 1998.

MONTENEGRO, M. R. o circuito inferior da economia urbana na cidade de São Paulo. Dissertação de Mestrado, Departamento de Geografia, Universidade de São Paulo, 2006.

NUCLEO DE ESTUDOS DE POLÍTICAS PÚBLICAS. Sumário executivo da pesquisa o setor saúde e o complexo da saúde no Brasil, caderno n.46, Universidade Estadual de Campinas, 2000. 
OLIVEIRA, E.X.G; CARVALHO, M.S; TRAVASSOS, C. "Territórios do Sistema Único de Saúde - mapeamento das redes de atenção hospitalar". In: Caderno de Saúde Pública, Rio de Janeiro, 20 (2): 386-402, mar-abr, 2004.

ORTEGA Y GASSET, J. Meditação da Técnica. Rio de Janeiro: Livro Ibero Americano, Lisboa, [1939] 1963.

PICKENHAYN, J. 2006 "Geografía para la salud: uma transición - algunos ejemplos del caso argentino”. In: Lemos, A.I. G.; Silveira, M.L. e Arroyo, M. (Org.) Questões territoriais na América Latina. Buenos AiresSão Paulo: CLACSO-Universidade de São Paulo, p. 261-275.

PINHEIRO, R.S; TRAVASSOS, C; GAMERMAN; CARVALHO, M.S. "Mercados Hospitalares em Área Urbana: uma abordagem metodológica”. In: Caderno de Saúde Pública, Rio de Janeiro, 17(5): 1111-1121, set-out, 2001.

RAfFestin, C. Por uma geografia do poder. Ática, São Paulo, [1980] 1993.

RAMIRES, J. C. L. "Cidades médias e serviços de saúde: algumas reflexões sobre os fixos e os fluxos", In: Sposito, M. E. B. (Org.) Cidades médias: espaços em transição. São Paulo: Ed. Expressão Popular, 2007.

RAWLS, J. Justiça com equidade - uma reformulação. Martins Fontes, São Paulo. 2003.

RIBEIRO, A. C. T. "Tecnologias da informação e comunicação, saúde e vida metropolitana”. In: Revista Interface - Comunicação, Saúde, Educação, v.2, n.2, 1998 .

, A. C. T. "A natureza do poder: técnica e ação social”. In: Revista Interface - Comunicação, Saúde, Educação, v.4, n.7, p. 13-24. 2000.

A. C. T. "Regionalização: Fato e Ferramenta”. In: Brasil século XXI por uma nova regionalização? Ed. Max Limonad, São Paulo, [2004] 2008.

RIBEIRO, J. F. "O equipamento médico - uma atividade global em forte crescimento”. Informação Internacional, sup, p. 95-123, Departamento de Prospectiva e Planeamento, Lisboa, 2006.

RIEG, D. L.; ALVES FILHO, A. G. "Estratégias tecnológicas e desempenhos inovadores das PMEs de equipamentos médicos-hospitalares de São Carlos e Ribeirão Preto”. In: Revista Produção, v.17, n.2, p. 273-285, mai-/ago, 2007.

RODRIGUES, P. H.; SANTOS, I. S. Saúde e Cidadania: uma visão histórica e comparada do SUS. Editora Atheneu. São Paulo, 2009.

ROJAS, L. I. "Salud y Bienestar Humano em La Geografia de América Latina”. In: Lemos, A.I. G.; Silveira, M.L. e Arroyo, M. (Org) Questões territoriais na América Latina. Buenos Aires-São Paulo: CLACSOUniversidade de São Paulo, p. 221-248, 2006.

ROSANVALLON, P. O Liberalismo econômico: historia da idéia de mercado. Tradução: Antonio Penalves Rocha. EDUSC. Bauru, [1979] 2002.

SANTOS, M. "Sociedade e Espaço: a Formação Social como Teoria e como Método". In: Boletim Paulista de Geografia, n 54, jun., p. 81-100. São Paulo, 1977 .

, M. Economia espacial - críticas e alternativas. São Paulo: Edusp, [1979] 2003. 
M. O Espaço Dividido - os dois circuitos da economia urbana dos países subdesenvolvidos. São Paulo: Edusp, [1979] 2004.

, M. Manual de geografia urbana. São Paulo: Edusp, [1981] 2008.

, M. Espaço e método. São Paulo: Edusp, [1985] 2008.

, M. O espaço do cidadão. São Paulo: Nobel, [1987] 1998.

, M. "O meio técnico-científico e a urbanização no Brasil”. In: Espaço \& Debates: reestruturação econômica e transformações territoriais. Ano VIII - n. 25, 1988.

, M. “Metrópole: a força dos fracos é seu tempo lento". Ciência \& Ambiente, IV (7), jul/dez, 1993.

M. Por uma economia política da cidade - o caso de São Paulo. Hucitec-Educ, São Paulo, 1994.

M. Técnica, Espaço, Tempo: globalização e meio técnico-científico informacional. 4. Ed. Editora Hucitec. São Paulo, [1994] 1998.

, M. "O retorno do território". In: Santos, M.; Souza M. A. A. de e Silveira M. L., Território: Globalização e Fragmentação, Hucitec-ANPUR, São Paulo, 1994, pp.15-20

, M. A Natureza do Espaço - técnica e tempo razão e emoção. São Paulo: Hucitec, 1996.

M. "El espacio banal, una epistemologia de la existência”. Discurso de aceptación de su investidura como Doctor Honoris Cauda da Universitat de Barcelona, 13 novembro de 1996.

M. "Nação, Estado e Território”. In: Mendonça, S; Motta, M. Nação e Poder: as dimensões da história. EdUFF, Niterói, 1998.

M. Por uma outra globalização. Do pensamento único à consciência universal. Rio de Janeiro: Record, 2000.

, M. Testamento Intelectual. Ed. Unesp, São Paulo, [2002] 2004.

M. Saúde e ambiente no processo de desenvolvimento. In: Ciência \& Saúde Coletiva, 8 (1): 309-314, 2003.

, M. e RIBEIRO, A. C. T. o conceito de Região Concentrada, Rio de Janeiro, UFRJ, IPPUR e Departamento de Geografia, 1979 (mimeo).

M. e SILVEIRA, M. L. O ensino superior público e particular e o território brasileiro. ABMES, Brasília, DF, 2000.

M. e SILVEIRA, M. L. O Brasil - território e sociedade no início do século XXI. Rio de Janeiro: Record, 2001.

SANTOS, M. A. B.; GERSCHMAN, S. As segmentações da oferta de serviços de saúde no Brasil: arranjos institucionais, credores, pagadores $e$ provedores. In: Ciência e Saúde Coletiva, Rio de Janeiro, v. 9, n. 3, p. 795-806, 2004.

SARTRE, J-P. A Crítica da Razão Dialética. Tradução: Guilherme João de Fritas Teixeira. Ed. DP\&A, Rio de Janeiro, [1960] 2002.

, J-P. Sartre no Brasil: a conferência de Araraquara. Tradução: Luiz Roberto Salinas Fortes. 2. ed. Editora Unesp, São Paulo, [1960] 2005. 
SEN, A. "Life and Death in China: a Reply”. World Development, 20 (9): 13051312.

SENNETT, R. A Cultura do Novo Capitalismo. Tradução: Clóvis Marques. Rio de Janeiro, Record, 2006.

SILVA, L. K. “Avaliação tecnológica e análise custo-efetividade, em saúde: a incorporação de tecnologias e a produção de diretrizes clínicas para o SUS”. In: Ciência \& Saúde Coletiva, 8(2): 501-520, 2003.

SILVEIRA, M. L. "Concretude territorial, regulação e densidade normativa”. Experimental, São Paulo, v. 1, n. 2, p. 35-45, 1997.

M. L. “Uma situação geográfica: do método à metodologia”. In: Território, ano IV, n 6, jan/jun. São Paulo, 1999.

M. L. "Indagando as técnicas: um caminho para entender o território”. In: Os Lugares do mundo - globalização dos Lugares, Gonçalves, N. M. S.; Silva, M. A.; Lage, C. S. (Org.), Universidade Federal da Bahia, Salvador, BA, 2000.

M. L. "Os circuitos da economia urbana nas cidades brasileiras". In: VIII Seminário Internacional da Rede Ibero-americana de Investigadores sobre Globalização e Território. Rio de Janeiro, 2004.

, M. L. "Globalización y circuitos de la economia urbana en ciudades brasileñas”. In: Cuadernos Del Cendes, ano 21, n.57, tercera época, septiembre-diciembre, p. 1-21, Caracas, 2004.

M. L. "São Paulo: os dinamismos da pobreza". In: CARLOS, A. F. A.; OLIVEIRA, A. U. (Org.). As geografias de São Paulo. 1 ed. São Paulo: Contexto, v. 1, p. 59-71, 2004.

M. L. "Metrópolis brasileñas: um análisis de los circuitos de la economia urbana” em: Revista Eure, vol XXXIII, n.100, p. 149-164. Santiago de Chile, diciembre, 2007.

M. L. Crises e Paradoxos da Cidade Contemporânea: os Circuitos da Economia Urbana. Texto apresentado no X Simpósio Nacional de Geografia Urbana, CD-R, Florianópolis, 2007.

M. L. Globalización y finanzas: circuitos de La economía urbana en La ciudad de San Pablo. In: X Seminario de la Red Iberoamericana de Investigadores en Globalización y Territorio. Memorias del $X$ Seminario Internacional de la RII. Santiago de Querétaro, 2008.

M. L. "Metrópoles do Terceiro Mundo: da história ao método, do método à história”. In: SILVA, C. A.; CAMPOS, A. (Org.). Metrópoles em mutação. Dinâmicas territoriais, poder e vida coletiva. 1 ed. Rio de Janeiro: Revan, v. 1, p. 17-35, 2008.

M. L. "Ao Território Usado a Palavra: pensando princípios de solidariedade socioespacial”. In: d'Avila Viana, A. L.; Ibañez, N.; Elias, P. E. (Org.) Saúde Desenvolvimento e Território, 2009, p.127-150.

M. L. "Los Territorios Corporativos de la globalización”. In: Geograficando - Revista de Estudios Geográficos, v. 3, n. 3, 13-26, 2007.

M. L. "Los confines de la racionalidad: el espacio geográfico contemporáneo”. XI Encuentro de Geógrafos de América Latina. Bogotá, março de 2007. Anais. 17p. Bogotá, 2007. 
M. L. "Escala Geográfica: da ação ao império?” In: Terra Livre, Goiânia, ano 20, v. 2, n. 23, p. 87-96, jul.-dez, 2004.

M. L. "Por Que Há Tantas Desigualdades Sociais No Brasil”. ALBUQUERQUE, E.S. Que País é Esse? 1. ed. Editora Globo, São Paulo, 2006.

SIMONDON, G. Du mode déxistence des objets techniques. Albier, Paris [1958] 1989.

G. Sobre a tecno-estética: carta a Jacques Derrida. In: ARAÙJo, H. R. (org.) Tecno-ciência e Cultura: ensaios sobre o tempo presente. Estação Liberdade, São Paulo, 1998.

SMITH, N. Desenvolvimento desigual. Bertrand Brasil, Rio de Janeiro, 1988

SORRE, M. Les fondements de la géographie humaine. Paris, A. Colin, t. I, 1947.

SOUZA, J.H; CAPPA, J; NEVES, L.C. "Concentração Regional da Indústria de Produtos Médicos”. In: São Paulo em Perspectiva, v. 22, n.1, p. 123136, jan-/jul. 2008.

SouZA, M. A. A. de. "Conexões geográficas: um ensaio metodológico". Boletim Paulista de Geografia, n.17, p.113-127, I sem./1992.

TEIXEIRA C. M. “Epidemiologia e planejamento de saúde”. Ciência e Saúde Coletiva, v.4 p.287-303, 1999.

THEIS, I. M. "Ciência \& tecnologia e desenvolvimento geográfico desigual no Brasil”. In: REDES, Santa Cruz do Sul, v. 14, n.1, p. 62-81, jan-/abr. 2009.

TRAVASSOS, C.; VIACAVA, F.; FERNANDES, C.; AlMEIDA C, M. "Desigualdades geográficas e sociais na utilização de serviços de saúde no Brasil”. Ciência e Saúde Coletiva, v.5, p.133-149, 2000.

VAlLAUX, C. El suelo y el Estado, Madrid: Daniel Jorro Editor, 1914, p. 265334.

VARGAS, E. V. "Multiplicando os agentes do mundo: Gabriel Tarde e a sociologia infinitesimal”. In: Revista Brasileira de Ciências Sociais. V. 19. n.55, 2004 .

VERCESI, M. A. "Território Usado e Saúde - respostas do Sistema Único de Saúde à situação geográfica de metropolização em Campinas”. Dissertação de Mestrado em Geografia Humana, FFLCH/ USP. São Paulo, 2006.

VIANA, A. L.; et al. "Sistema de saúde universal e território: desafios de uma política regional para a Amazônia Legal”. In: Caderno de Saúde Pública, v. 23 sup. 2: S117-131. Rio de Janeiro, 2007.

ZANCHI, M. T.; ZUGNO, P.L. Sociologia da Saúde. EdUSC, Caxias do Sul, 2008.

ZAOUAL, H. Nova Economia das Iniciativas Locais: uma introdução ao pensamento pós-global. Tradução: Michel Thiollent. DP\&A: Consulado Geral da França: COPPE/UFRJ, 2006. 